FERNANDA CAROLINA DE ARAUJO

\title{
A TEORIA CRIMINOLÓGICA DO LABELLING APPROACH E AS MEDIDAS SOCIOEDUCATIVAS
}

\author{
DISSERTAÇÃO DE MESTRADO
}

ORIENTADOR: PROF. SÉRGIO SALOMÃO SHECAIRA

FACULDADE DE DIREITO DA UNIVERSIDADE DE SÃO PAULO

SÃO PAULO

2010 
FERNANDA CAROLINA DE ARAUJO

\section{A TEORIA CRIMINOLÓGICA DO LABELLING APPROACH E AS MEDIDAS SOCIOEDUCATIVAS}

Dissertação apresentada à Faculdade de Direito da Universidade de São Paulo como requisito parcial para a obtenção do título de Mestre em Direito (área de concentração Direito Penal, Medicina Forense e Criminologia), sob a orientação do Professor Titular Sérgio Salomão Shecaira.

ORIENTADOR: PROF. SÉRGIO SALOMÃO SHECAIRA

FACULDADE DE DIREITO DA UNIVERSIDADE DE SÃO PAULO

SÃO PAULO

2010 
FERNANDA CAROLINA DE ARAUJO

\section{A TEORIA CRIMINOLÓGICA DO LABELLING APPROACH E AS MEDIDAS SOCIOEDUCATIVAS}

Dissertação apresentada à Faculdade de Direito da Universidade de São Paulo como requisito parcial para a obtenção do título de Mestre em Direito (área de concentração Direito Penal, Medicina Forense e Criminologia), sob a orientação do Professor Titular Sérgio Salomão Shecaira.

Aprovado em

BANCA EXAMINADORA 
Aos meus pais, Fernando e Vera, um agradecimento especial por, simplesmente, serem meus pais. Não pode existir bem maior que esse.

Ao Rogério, meu futuro marido, por ser a metade que faltava para me completar e sem a qual nada faz sentido.

Ao meu querido irmão, que sempre esteve comigo em todos os momentos importantes da minha vida. 


\section{AGRADECIMENTOS}

Nada é conseguido sozinho. É sempre necessária a colaboração de pessoas e entidades queridas para o sucesso de algum projeto de vida, qualquer que seja ele.

Aqui não foi diferente e por isso é preciso de um espaço para agradecer a todos que estiveram comigo durante o meu mestrado.

Agradeço ao professor Sérgio Salomão Shecaira, que nesses últimos três anos foi mais do que meu orientador, mas um amigo que participou de todo o nascimento desta dissertação, bem como do meu nascimento no mundo acadêmico.

Aos professores da Faculdade de Direito da Universidade de São Paulo, especialmente aos que compuseram minha banca de qualificação, professor Alvino Augusto de Sá e professora Ana Elisa Liberatore Bechara, os quais aclararam o caminho que deveria seguir e me deram confiança para continuar a trilhá-lo.

A todos os amigos que fiz na Faculdade de Direito da Universidade de São Paulo, companheiros da vida acadêmica, sem os quais esta experiência não teria sido tão rica e prazerosa.

Aos funcionários da Faculdade de Direito da Universidade de São Paulo, especialmente a Dalva, secretária do Departamento de Direito Penal, Medicina Forense e Criminologia, sempre alerta para atender a todas as solicitações.

Ao Instituto Brasileiro de Ciências Criminais, IBCCRIM, espaço de debates tão determinante na minha formação como estudante e como pessoa.

Aos meus amigos coordenadores do Laboratório de Iniciação Científica do IBCCRIM, com os quais dividi minhas angústias e minhas horas de lazer.

Aos meus amigos coordenadores dos grupos Getcrim e GDUCC, por permitirem que eu participasse desse trabalho construído com tanto carinho e dedicação.

Aos promotores de Justiça de Indaiatuba, com os quais aprendi lições para a vida toda.

Finalmente, não posso terminar esta passagem sem fazer um agradecimento especial ao meu pai, que muito mais do que ter me apoiado na minha imersão nos estudos, viveu comigo essa fase, sem nunca me cobrar nada e sem nunca duvidar que eu conseguiria. Sem você, pai, nada teria sido possível. 
Certamente nos atribuíam culpas graves; na melhor das hipóteses éramos levianos e desastrados. E o pior é que nos sentíamos infratores, éramos levados a admitir isto. Sinais intempestivos de compaixão, simples referência ao ambiente sórdido, à horrível miséria, mais nos reforçariam a certeza. Tínhamos delinquido, sem dúvida. Muitas daquelas criaturas ignoravam que delito lhes imputavam. Na verdade não imputavam: mantinham-nas em segregação, $e$ isto devia bastar para convencê-las.

(Graciliano Ramos, Memórias do Cárcere) 


\section{RESUMO}

A presente dissertação ocupa-se do estudo da teoria criminológica da rotulação social e do sistema de justiça juvenil visando, ao final, a aproximar essas duas esferas de conhecimento e verificar a assertividade das lições emanadas da mencionada teorização no tocante à aplicação e a execução das medidas socioeducativas. O caminho criminológico percorrido inicia-se com o surgimento da Criminologia chegando até a teoria crítica, sucessora da rotulação social. No que se refere à Justiça Juvenil são apresentados todos os paradigmas que direcionaram seu entendimento, atendo-se ao estudo das medidas socioeducativas e suas finalidades, destacando-se a sanção mais gravosa, a internação. A junção dos conhecimentos ocorre com o estudo dos efeitos da internação e sua ligação com a possibilitação de uma carreira criminosa.

Palavras-chave: Criminologia; Rotulação Social; Sistema de Justiça Juvenil; Medidas socioeducativas. 


\begin{abstract}
The present dissertation occupies itself of the study of the labelling approach criminological theory and of the juvenile justice system intending to, in the end, approach those two spheres of knowledge and verify the certainty of the lessons emanated of the aforementioned theory regarding the application and the execution of the socialeducational measures. The criminological path passed through begins with the emergence of Criminology reaching the critical theory, successor of the labelling approach. Regarding the Juvenile Justice, are presented all of the paradigms that directed its understanding, focusing in the study of social-educational measures and its purposes, especially the most severe penalty, the admission. The intersection of the knowledge takes place with the study of the effects of the admission and its connection with the making-possible of a criminal career.
\end{abstract}

Keywords: Criminology; Labelling approach; Juvenile Justice System; Social-educational measures. 


\section{SUMÁRIO}

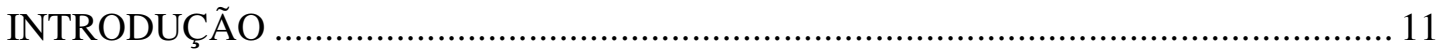

CAPÍTULO 1. SURGIMENTO DA CRIMINOLOGIA................................................ 15

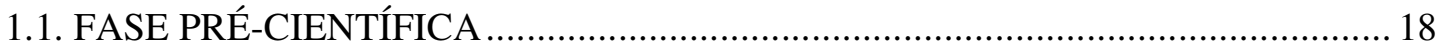

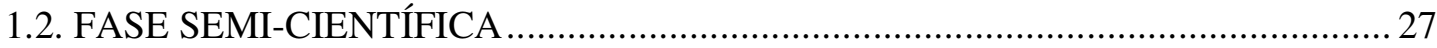

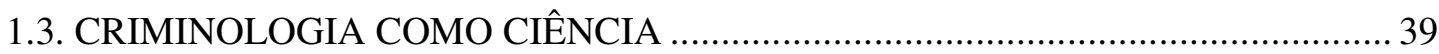

1.3.1. Criminologia do Consenso .......................................................................... 43

1.3.1.1. Teoria da Ecologia Criminal..................................................................... 45

1.3.1.2. Teoria da Associação Diferencial ............................................................ 51

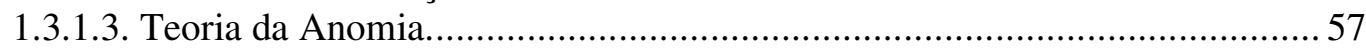

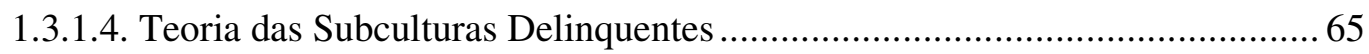

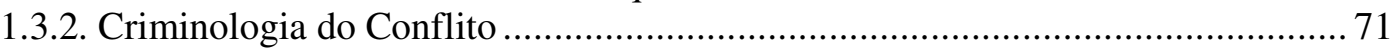

1.3.2.1. Teoria do Labelling Approach ................................................................. 77

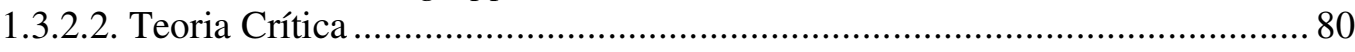

CAPÍTULO 2. TEORIA DO LABELLING APPROACH ………………....................... 84

2.1. CONTEXTO HISTÓRICO-SOCIAL DO NASCIMENTO DA TEORIA ....................84

2.2. BASES INTERDISCIPLINARES PROPULSORAS ………………………......... 91

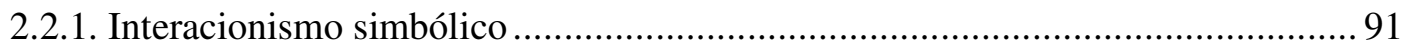

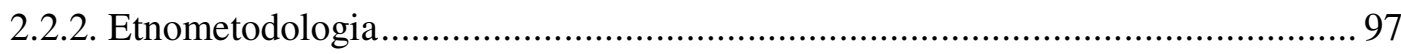

2.3. PROPOSTA DE INVESTIGAÇÃO CRIMINOLÓGICA ………………………....... 100

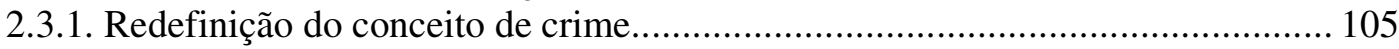

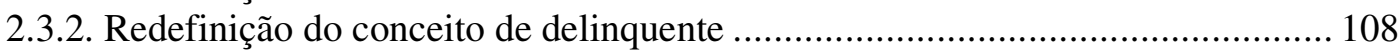

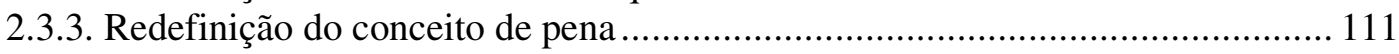

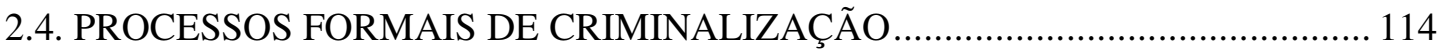

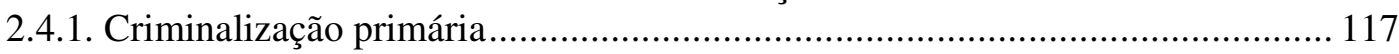

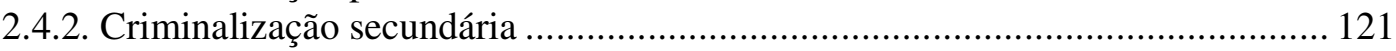

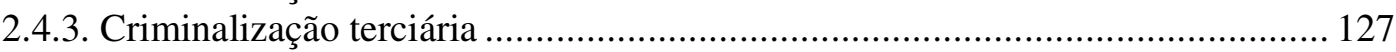

2.4.3.1. A atribuição da etiqueta de desviado e o processo de estigmatização .......... 128

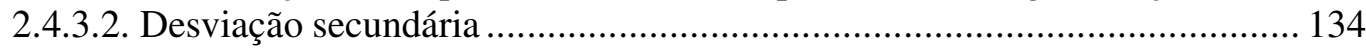

CAPÍTULO 3. EVOLUÇÃO DO TRATAMENTO JURÍDICO E CRIMINOLÓGICO DISPENSADO A CRIANÇAS E ADOLESCENTES EM CONFLITO COM A LEI..... 139



3.2. ESPECIALIZAÇÃO DA JUSTIÇA JUVENIL ....................................................... 144 
3.2.1. Finalidades das medidas impostas a crianças e adolescentes na história da Justiça

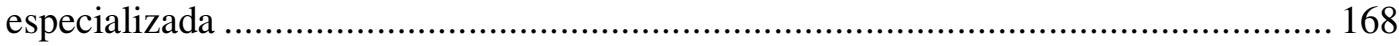

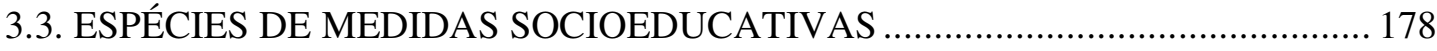

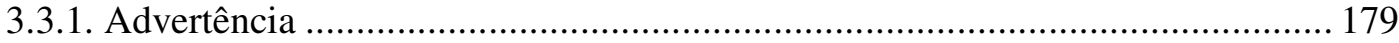

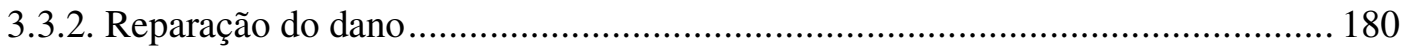

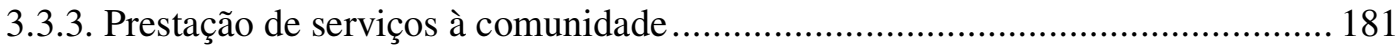

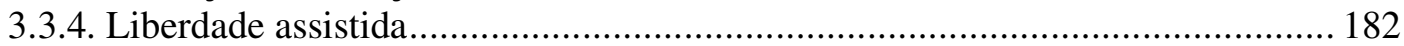

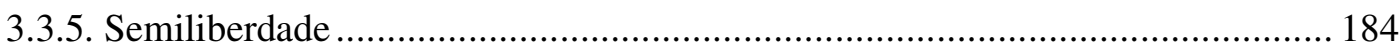

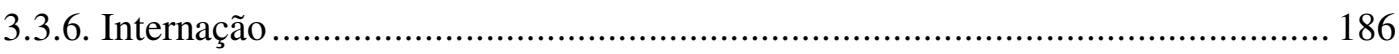

CAPÍTULO 4. INSTITUCIONALIZAÇÃO E PRISIONIZAÇÃO ................................. 195

4.1 EFEITOS INSTITUCIONALIZANTES DA INTERNAÇÃO: O INÍCIO DAS

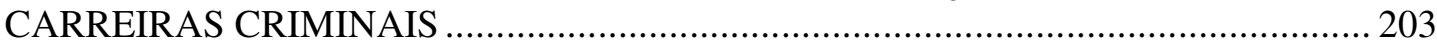

4.1.1. As carreiras criminais: conexão entre internação e a pena privativa de liberdade na formação da identidade delinquente.................................................................... 211

4.1.1.1. The Jack-Roller: A delinquent boy's own history................................. 213

4.1.1.2. Os Filhos do Governo: A formação da identidade criminosa em crianças órfãs

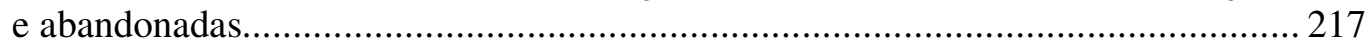

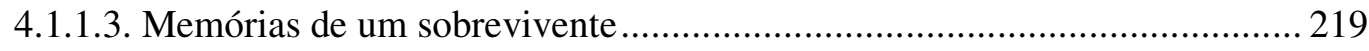

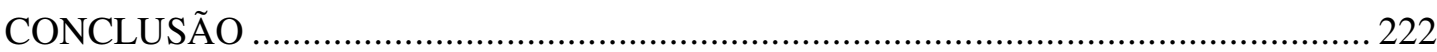

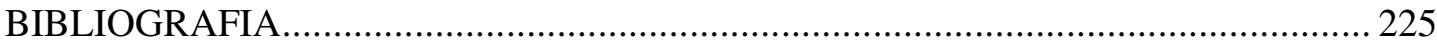




\section{INTRODUÇÃO}

A teoria do labelling approach, rotulação social ou etiquetagem, surgida no início da década de 1960, representou uma inovação no estudo da Criminologia mundial, ficando conhecida, em um primeiro momento, como teoria crítica.

Isso porque iniciou uma nova abordagem da ciência que, rompendo com os fundamentos do paradigma etiológico da Criminologia clássica, passou a ater-se aos reflexos do controle exercido pelo Estado sobre o pretenso criminoso. Em outras palavras, a Criminologia deixou de perquirir as causas para indagar as condições da criminalidade.

A nova teoria, então, estreou uma análise do problema da criminalidade em que este era tomado como consequência da intervenção do controle social formal.

A repressão institucionalizada só deve ter lugar quando todos os demais mecanismos de controle informais forem falhos, porque é estigmatizante. Para a rotulação social é essa intervenção do aparelho estatal repressivo que facilita o desenvolvimento de um instinto criminoso no indivíduo, início de uma possível carreira criminosa.

Assim, a interferência da Justiça, nos moldes hoje apresentados, é apta a aprofundar a criminalidade, e não a contê-la.

Mesmo com uma pretensa abordagem diversa da Justiça Penal Juvenil, tal ciclo também se demonstra nessa seara, precipuamente no que concerne à imposição de uma sanção de privação de liberdade, não obstante a opinião de diversos doutrinadores que não enxergam nas medidas socioeducativas qualquer conteúdo retributivo.

É corrente o discurso do senso comum de que a legislação brasileira é falha e de que a causa dos inúmeros (pensa-se erroneamente serem muitos) atos infracionais praticados por adolescentes é a total ausência de punição ou a responsabilização deveras branda desses sujeitos.

Desse modo, e visando a desconstruir essas incorreções, é que se pretende unir as lições da Justiça Juvenil e da Criminologia e analisar a repercussão da teoria da rotulação social no âmbito do Direito Penal Juvenil, no momento da execução das medidas socioeducativas. 
A escolha em se perquirir a questão da adolescência infracional sob a o enfoque da teoria do labelling approach deve-se ao fato de pouquíssimas obras ocuparem-se de forma específica dessa formulação teórica, a qual revolucionou o entendimento criminológico que, até a década de 1960, estava viciado pelos conceitos positivistas. Ademais, não se pode olvidar que "o saber científico é um meio importante e indispensável através do qual a voz das crianças pode ser ouvida na programação e na avaliação das políticas dirigidas à proteção dos seus direitos"

Por conseguinte, visando a atingir o objetivo pretendido, apresenta-se no primeiro capítulo um estudo dos aportes iniciais da Criminologia, enfrentando-se questões controversas, tais como a celeuma que envolve a fixação do termo de nascimento da citada ciência, bem como a discussão acerca de sua cientificidade. Realiza-se ainda uma sucinta análise da evolução das teorias criminológicas, buscando sedimentar os conhecimentos dominantes anteriormente ao surgimento do labelling approach.

Trata-se, outrossim, da concepção da pena em cada escola criminológica, e, quando existente, do entendimento acerca do comportamento infrator juvenil, ofertado por cada qual delas.

Isso cria uma base sólida de conhecimentos acerca dos períodos iniciais da Criminologia para que, no segundo capítulo, possa se demonstrar a mudança de referenciais possibilitada pela formulação da primeira teoria criminológica que tomou por premissa a existência de um grupo social baseado no conflito.

Assim, faz-se nesse capítulo uma análise acurada da teoria do labelling approach, embasada pela leitura de obras criminológicas atuais e, sobretudo, pela investigação dos textos de autores precursores desta formulação científica.

Nesse diapasão, explana-se, inicialmente, o caldo cultural que caracterizava as sociedades da época e que tornou possível uma mudança tão radical na seara criminológica, bem como as bases teóricas sobre as quais foi construída a teoria, provenientes de outras áreas do conhecimento, especialmente o interacionismo simbólico e a etnometodologia. Em seguida apresenta-se a proposta de estudo criminológico inaugurada pelo labelling approach, ou seja, os conceitos e conhecimentos sob os quais se erige o novo pensamento, por meio da redefinição de crime, criminoso e pena, esta por via

\footnotetext{
${ }^{1}$ BARATTA, Alessandro. Os direitos da criança e o futuro da democracia. In: Direito no início do século XXI. Coimbra: Coimbra Editora, 1999, p. 91. et al. Perspectivas do
} 
do questionamento crítico acerca de seu fim de ressocialização, bem como analisando-se a estrutura de controle social que a impõe.

Dedica-se ainda à análise dos diferentes processos de criminalização, cuja existência é denunciada pelo labelling approach, o que implica, necessariamente, uma abordagem dos sistemas de repressão penal formalizados pelo Estado. Trata-se dos processos de criminalização primária, secundária e terciária, por meio dos quais, respectivamente, uma conduta é definida como criminosa, exerce-se a aplicação da norma penal pela Polícia e pelo Poder Judiciário e executa-se a pena.

Decorrência dos citados procedimentos de criminalização, destaca-se o mecanismo de atribuição de uma etiqueta não querida a um sujeito submetido ao seletivo controle estatal e a estigmatização decorrente desta marca fixada ao indivíduo, apresentando-se, por derradeiro, a desviação secundária, consistente no estudo do impacto da atribuição do status de criminoso na identidade desviante, que pode dar início a construções de carreiras criminais.

No terceiro capítulo examina-se o tratamento dedicado aos jovens em conflito com a lei. Como forma de aproximação inicial ao tema das crianças e adolescentes suspeitos da prática de um ilícito, de antemão, analisa-se a evolução do pensamento jurídico e criminológico sobre o assunto, desde o momento de sua indiferenciação até a constatação da necessidade da especialização no trato juvenil. É aqui, vale dizer, que se demonstra a influência que teve o equivocado pensamento positivista sobre esta matéria.

Dada a especialização desse domínio da justiça, investigam-se as finalidades das sanções aplicadas exclusivamente aos adolescentes comprovadamente autores de atos infracionais, denominadas medidas socioeducativas, e apresentam-se as distintas espécies de sanções juvenis, momento em que se enfatiza a medida de maior gravidade, qual seja a internação.

Por fim, no último capítulo, a interseção entre os conceitos criminológicos propostos pelo labelling approach e as medidas socioeducativas é enfatizada ao se relacionar a internação e seus efeitos com a prisionização. Pretende-se, neste ponto, apresentar a realidade da execução de uma privação de liberdade em instituições destinadas aos jovens em conflito com a lei, inclusive por meio do uso de dados recentes acerca do tratamento desrespeitoso a eles dispensado, da superlotação de alguns desses estabelecimentos, das rebeliões ocorridas, entre outros. 
Em seguida estuda-se um dos efeitos mais graves da institucionalização de um jovem que é o início de uma carreira criminosa. Para tanto, mister que se utilize de conceitos explicados no capítulo dois e integrantes deste processo, tais como o etiquetamento, o estigma e a desviação secundária .

Por fim, tendo em vista a relevância dada pelo labelling approach a essa metodologia de estudo, opta-se pela apresentação de histórias de vida em que se narra o desenvolvimento da carreira criminosa de alguns adultos que enveredaram na prática ilícita ainda jovens, após serem submetidos ao sistema de justiça juvenil. 


\section{CAPÍTULO 1. SURGIMENTO DA CRIMINOLOGIA}

Ao se introduzir o estudo de determinada ciência, geralmente se contenta com a apresentação e evolução de seus objetos e métodos de apreensão de suas conclusões. Ocorre que, numa disciplina tão peculiar quanto a Criminologia, essa análise não pode limitar-se às perquirições relatadas, inclusive porque ela não foi considerada como científica desde seu surgimento. Um longo caminho foi percorrido até que esse status fosse alcançado.

Sabe-se que "uma ciência não surge do nada, não provém de fiat genial, não brota do improviso criador. Sua trajetória desenvolve-se, mais ou menos acidentada ou demoradamente, até a conquista de lugar e papel definidos"2.

Assim, tratando-se da matéria em questão, não se pode dispensar o estudo histórico, inclusive como requisito para sua compreensão.

Isso porque "a perspectiva histórica surge como necessária para referenciar corretamente o complexo problema criminológico, que subsiste em cada uma das escolas mas que persiste para além de todas elas"3.

Corrobora ainda com a importância de uma detalhada apreensão de seu desenvolvimento o fato de até hoje não haver consenso entre os criminólogos acerca de seu marco inicial, bem como, e especialmente, do seu reconhecimento enquanto ciência. Para Shecaira, "se essa data fosse certa, seguramente ter-se-ia uma indicação mais precisa em uma obra ou em um pensamento determinado" ${ }^{.}$.

Para Bustos Ramírez a citada discussão acerca do marco inicial da Criminologia não tem um caráter meramente historicista, apontando, em realidade, para uma profunda controvérsia de caráter epistemológico. $\mathrm{Na}$ Ilustração o problema criminológico circunscreve-se a uma questão eminentemente política, ligada a concepção que se tem do Estado, e em relação de dependência com sua própria estrutura jurídico-políticoinstitucional. Em contrapartida, esse problema insere-se no Positivismo dentro de um contexto no qual já há um grupo social e um Estado formados, carentes apenas de

\footnotetext{
${ }^{2}$ LYRA, Roberto; JÚNIOR, João Marcello de Araújo. Criminologia. 2. ed. Rio de Janeiro: Forense, 1990. p. 34.

3 DIAS, Jorge de Figueiredo; ANDRADE, Manuel da Costa. Criminologia: o homem delinqüente e a sociedade criminógena. 2 reimp. Coimbra: Coimbra Editora, 1997. p. 4.

${ }^{4}$ SHECAIRA, Sérgio Salomão. Criminologia. 2. ed. rev. São Paulo: Revista dos Tribunais, 2008. p. 81.
} 
consolidação. Sendo assim, basta acomodar as questões indesejadas e, concomitantemente, buscar a extirpação de suas causas, evitando, pois, sua repetição ${ }^{5}$.

Note-se, então, a profunda diferença aí existente. Enquanto a primeira parte de conceitos absolutos a priori, a segunda é relativa ao conformar-se com o que está posto, com o que já existe, obliterando-se a capacidade criativa do homem e tratando-o como mero sujeito que age e reage contra os fatos sociais.

Por tudo isso é que o citado jurista defende que a definição do início da Criminologia depende da postura teórica que se assuma diante do mundo social. Os que têm posturas críticas e acreditam na possibilidade de transformação do mundo remetem as origens criminológicas ao Iluminismo. Diversamente, os que creem que o mundo social já está dado, cabendo aos homens a tarefa de melhorá-lo e harmonizá-lo, as relacionam com o Positivismo ${ }^{6}$.

Da mesma opinião coaduna Zaffaroni, acrescentando que os que enxergam o criminoso como um ser anormal, necessitado de melhora, apontam para o Positivismo como o marco inicial da Criminologia. Em contrapartida, os que acreditam que as manifestações repressivas do poder derivadas do sistema penal e da reação penal devem ser questionadas e modificadas deslocam esse início para um momento anterior, com Beccaria e a Escola Clássica ${ }^{7}$.

Criminologia é uma expressão de origem híbrida, que deriva do latim e da língua grega. Do latim, tem-se a significação crime, delito, enquanto do grego, discurso, reflexão coerente. Assim, etimologicamente a palavra representa o estudo do crime, tarefa que, como se verá no próximo item, foi desenvolvida já pelos clássicos, de forma bastante concentrada.

Há relatos de que o termo foi utilizado pela primeira vez por Topinard, no ano de 1879, e mais tarde, em 1885, pelo positivista Garófalo, como título de uma de suas obras.

O delito, como uma das formas características do agir humano, aparece vinculado a todos os estágios de evolução dos povos. Por essa razão,

\footnotetext{
${ }^{5}$ BUSTOS RAMÍREZ, Juan. La Criminología. In: BERGALLI, Roberto; Pensamiento Criminológico: un análisis crítico. Bogotá: Temis, 1983. v. 1. ${ }^{6}$ BUSTOS RAMÍREZ, Juan. La Criminología. In: BERGALLI, Roberto; Pensamiento Criminológico: un análisis crítico. Bogotá: Temis, 1983. v. 1.

${ }^{7}$ ZAFFARONI, Eugenio Raúl. Criminología: aproximación desde un margen. Colômbia: Temis, 1993.

; MIRALLES, Teresa. El ; MIRALLES, Teresa. El
} 
poderia até se dizer que o grau de 'civilização' de um povo está marcado tanto pelas expressões de sua criminalidade como pela forma como o grupo manejou este fenômeno social, que sempre acompanhou o homem ${ }^{8}$.

Durante o período feudal as querelas eram resolvidas localmente, entre autor e vítima, mormente quando da existência de um dano.

É somente no final da Idade Média e início da Moderna que se passa a dar real importância aos conceitos de crime e criminoso, fator umbilicalmente ligado à instituição de um Estado soberano e a assunção para si do papel de resolução dos conflitos. Mas nesse momento considerado, o delito ainda era associado ao pecado, dada a estreita interdependência entre Estado, Direito e Igreja.

O Estado, encarregando-se de possibilitar a paz social, tomando para si o dever de responsabilização dos autores de delitos, passa a subjugar os papéis da vítima e do réu. Indicativo dessa forma de atuação diante das lides é o significado mesmo da expressão réu, que, originária do latim, significa coisa.

Juntamente com essa evolução das formas de repressão ao crime e da necessidade de compreensão dos fenômenos a ele ligados, solidificam-se também as pesquisas criminológicas.

A Criminologia, enquanto fórmula de pensar o fenômeno criminal, ao longo de sua evolução e constante reorganização, sofreu inúmeras mudanças. Estas não se limitam à citada celeuma acerca de sua aceitação como ciência ou não, mas envolvem também suas vertentes ideológicas e objetos de pesquisa.

A explicação do crime, do criminoso, do controle social e da vítima é tarefa bastante árdua que não pode ser encarada de maneira ingênua ou reducionista. Inclusive, chegar à constatação de que esses deveriam ser os objetos de estudo da Criminologia já foi empreitada bastante difícil, com a qual colaboraram todas as teorias criminológicas surgidas ao longo do desenvolvimento da matéria, cada qual com um paradigma de apreensão da realidade e ofertando uma visão específica sobre ela.

A existência de diversas formas de se apreciar a realidade humana, desde o ponto de vista desta matéria ${ }^{9}$, confirma a importância de todos os estudos que serão analisados no presente trabalho, a despeito de alguns terem sido mais exitosos em suas proposições do que outros.

\footnotetext{
${ }^{8}$ FONTALVO, Jorge Restrepo. Criminología: un enfoque humanístico. 3. ed. Colômbia: Temis, 2002. p. 25.

${ }^{9}$ FONTALVO, Jorge Restrepo. Criminología: un enfoque humanístico. 3. ed. Colômbia: Temis, 2002.
} 
Fato é que, "embora novos paradigmas raramente (ou mesmo nunca) possuam todas as potencialidades de seus predecessores, preservam geralmente, em larga medida, o que as realizações científicas passadas possuem de mais concreto" ${ }^{" 10}$.

O que se crê é que uma única abordagem não é capaz de explicar e entender toda a complexidade da questão criminal, sendo decorrente disso o fato de não se acreditar que uma única teoria possa fornecer todas as explicações sobre o tema ${ }^{11}$. Nesse sentido, então, é que se faz correta a afirmação de Zaffaroni de que "na criminologia todos os discursos estão vivos" $"$.

Evidente que, em se tratando de um fenômeno tão intimamente relacionado ao início dos agrupamentos humanos, a busca por respostas sobre a criminalidade não se inicia apenas na Idade Moderna, tendo havido sempre tentativas no sentido de encontrar as melhores formas de preveni-la e combatê-la ${ }^{13}$.

Malgrado o reconhecimento desse dado, opta-se aqui por iniciar este estudo pela Escola Clássica, período em que se identifica uma reflexão sistemática acerca dessas manifestações.

\subsection{FASE PRÉ-CIENTÍFICA}

Identifica-se esse período com o surgimento da chamada Escola Clássica da Criminologia, a qual tem fincadas raízes no Movimento Iluminista e na sua concepção de homem, dos Reformadores, bem como no Direito Penal Clássico.

O movimento da Ilustração, com reflexos em todas as áreas do saber, deveu sua força econômica ao aumento da produção e do comércio possibilitado pelos avanços técnicos ${ }^{14}$, o que fez surgir uma forte classe social denominada burguesia, da qual saíram os principais pensadores do período.

Esse novel grupo que se erigia, detentor de riquezas, mas não do poder, o qual concentrava-se apenas nas mãos da nobreza, procurava fórmulas para limitar a autoridade

\footnotetext{
${ }^{10}$ KUHN, Thomas S. A estrutura das Revoluções Científicas. 8. ed. São Paulo: Perspectiva, 1982. p. 212.

${ }^{11}$ Tal problemática será apresentada de forma mais acurada no capítulo 2 do presente trabalho.

${ }^{12}$ ZAFFARONI, Eugenio Raúl. El curso de la Criminología. Ciencias Penales. Revista de la Asociación de Ciencias Penales de Costa Rica, San José, v. 12, n. 18, p. 7-11, nov. 2000 . p. 8.

${ }^{13}$ Sobre os estudos antecedentes à Criminologia ver ANITUA, Gabriel Ignacio. Histórias dos pensamentos criminológicos. Tradução de Sérgio Lamarão. Rio de Janeiro: Revan, 2008; e SHECAIRA, Sérgio Salomão. Criminologia. 2. ed. rev. São Paulo: Revista dos Tribunais, 2008.

${ }^{14}$ ANITUA, Gabriel Ignacio. Histórias dos pensamentos criminológicos. Tradução de Sérgio Lamarão. Rio de Janeiro: Revan, 2008.
} 
dos soberanos, em todas suas áreas de atuação, e especialmente no âmbito penal, no qual estavam em jogo os bens mais valiosos dos cidadãos, tais como a vida e a liberdade.

Formava-se a partir daí uma nova organização social fortemente influenciada pela teoria do contrato social dos filósofos Hobbes, Montesquieu e Rousseau, teoria esta que cumpriria um papel primordial para o fortalecimento burguês.

Em termos gerais, por ela, os indivíduos abririam mão de parcela de suas liberdades em favor da instituição de um Estado apto a protegê-los, utilizando-se de sanções de natureza penal, quando imperioso, para atingir tal objetivo.

Esse novo discurso contratual, portanto artificial, contrapõe-se ao natural defendido pela nobreza. Por este, a sociedade era encarada como um organismo, cujos órgãos ostentavam cada qual uma função diversa, emanada da vontade divina, sendo o poder político a missão da nobreza ${ }^{15}$.

Tratava-se de um período em que se facilitava a insegurança jurídica por não haver prévia determinação dos crimes e de suas respectivas sanções, encontrando-se o Direito Penal disperso em inúmeros corpos esparsos, quase ininteligíveis até para os experientes juristas da época.

Dada a supremacia da nobreza, era comum a utilização, pelo príncipe, do aviso régio. Consistia numa ordem, emanada exclusivamente do referido governante, escrita em carta fechada, com a finalidade de enviar alguém ao exílio, sequestrá-lo e constituí-lo prisioneiro $^{16}$.

A efervescência na busca pelo saber fez surgir uma infinidade de concepções distintas acerca do absolutismo, mas ideologia comum era a da necessidade de limitar e justificar o poder de punir dos governantes, em face da liberdade individual dos $\operatorname{cidadãos}^{17}$.

O que se pode seguramente dizer é que tinham os filósofos da Ilustração o espírito crítico e a crença na mente humana.

Somente nesse período se introduz uma doutrina jurídico-filosófica a respeito do regime de intervenção do Estado nos crimes e nas penas, que passa, apenas bem mais tarde, a ser referenciada como Escola Clássica.

\footnotetext{
${ }^{15}$ ZAFFARONI, Eugenio Raúl. Criminología: aproximación desde un margen. Colômbia: Temis, 1993.

${ }^{16}$ SALDAÑA, Quintiliano. Nova Criminologia. Tradução de Alfredo Ulson e V. de Alcântara Carreira. 2. ed. Campinas: Russel, 2006.

${ }^{17}$ ANDRADE, Vera Regina Pereira de. A ilusão da segurança jurídica: do controle da violência à violência do controle penal. 2. ed. Porto Alegre: Livraria do Advogado, 2003.
} 
Inicia-se nesse marco uma luta contra as penas cruéis utilizadas como instrumentos de vingança, contra as arbitrariedades cometidas pelo rei e pelos magistrados, contra a indeterminação dos crimes e das penas, contra a inexistência de leis claras e escritas, contra a tortura como forma de obtenção da confissão e também contra os julgamentos secretos.

Evidencia-se, pois, a existência, pela primeira vez, de uma reflexão de natureza sistemática sobre o fenômeno criminal, sendo por isso identificado aqui, por muitos autores, o nascimento da Criminologia ${ }^{18}$.

Daí, pois, a importância dessa Escola para o Direito Penal, o Processo Penal e a Criminologia.

É claro que antes, muito antes desse período, como já mencionado, pode-se localizar a existência de estudos de corte criminológico. No entanto, tal fenômeno não estava sistematizado e era mero reflexo da preocupação existente com o conhecimento e combate ao desvio ${ }^{19}$.

Um dos maiores expoentes do pensamento do século XVIII, na seara penal e criminológica, é sem dúvida Cesare Bonesana, o Marquês de Beccaria ${ }^{20}$.

Seu livro mais famoso, Dos delitos e das penas, foi publicado no ano de 1764, quando seu autor contava com apenas vinte e seis anos de idade. Seus principais objetivos eram denunciar os desmandos cometidos durante o processo e nas prisões da época, tendo como impulso seu contato pessoal com esse sistema, bem como apresentar reformas que urgiam por implementação ${ }^{21}$.

\footnotetext{
${ }^{18}$ Coadunam deste entendimento: DIAS, Jorge de Figueiredo; ANDRADE, Manuel da Costa. Criminologia: o homem delinquiente e a sociedade criminógena. 2 reimp. Coimbra: Coimbra Editora, 1997; ANDRADE, Vera Regina Pereira de. A ilusão da segurança jurídica: do controle da violência à violência do controle penal. 2. ed. Porto Alegre: Livraria do Advogado, 2003; ZAFFARONI, Eugenio Raúl. Criminología: aproximación desde un margen. Colômbia: Temis, 1993; SALDAÑA, Quintiliano. Nova Criminologia. Tradução de Alfredo Ulson e V. de Alcântara Carreira. 2. ed. Campinas: Russel, 2006; MAÍlLLO, Alfonso Serrano. Introdução à Criminologia. Tradução de Luiz Régis Prado. São Paulo: Editora Revista dos Tribunais, 2007; GARRIDO, Vicente; STANGELAND, Per; REDONDO, Santiago. Principios de Criminología. 2. ed. Valência: Tirant lo blanch, 2001; DEBUYST, Christian; DIGNEFFE, Françoise; LABADIE, Jean-Michel; PIRES, Alvaro P. Histoire des savoirs sur le crime \& la peine. Bruxelas: De Boeck-Wesmael, 1995. v. 1; CID MOLINÉ, José; LARRAURI PIJOAN, Helena. Teorías Criminológicas: explicación y prevención de la delincuencia. Barcelona: Bosh, 2001.

${ }^{19}$ Pode-se identificar o início de um discurso criminológico com a Inquisição e suas justificativas para perseguição dos hereges e das bruxas. Cf. ANITUA, Gabriel Ignacio. Histórias dos pensamentos criminológicos. Tradução de Sérgio Lamarão. Rio de Janeiro: Revan, 2008. .

${ }^{20}$ Beccaria tinha formação econômica e seu interesse pela temática do controle social foi motivada, dentre outros fatores, pelas reuniões de ilustrados que ocorriam em torno dos irmãos Verri, na cidade de Bolonha, das quais ele costumava participar. Cf. MAÍlLO, Alfonso Serrano. Introdução à Criminologia. Tradução de Luiz Régis Prado. São Paulo: Editora Revista dos Tribunais, 2007.

${ }^{21}$ Beccaria foi preso em decorrência de um desentendimento que teve com seu pai, quem por isso utilizou-se de sua influência para conseguir a privação de liberdade de seu filho, numa prisão de masmorra existente no
} 
Beccaria não criou nenhuma ideia inovadora em seu livro, sendo seu grande mérito a compilação e organização de todas as ideias isoladamente defendidas por seus respectivos criadores. Desse modo,

sua obra consiste numa das primeiras exposições globais e articuladas do direito penal, do direito processual penal e da criminologia, orientando-se pelos conhecimentos de filosofia política, mas aplicando-os sempre a esta matéria com uma análise evidentemente jurídica ${ }^{22}$.

Após tecer críticas ao sistema penal vigente, já numa dimensão positiva o autor defende a utilidade da pena para prevenir a prática de futuros delitos e não mais como expressão de um sentimento vindicativo. Prega ainda a divisão dos poderes, a humanidade das penas, sua rápida e justa aplicação, o princípio da legalidade dos delitos e das penas, bem como a proporcionalidade entre ambos.

Utiliza como critério de determinação da medida da pena o prejuízo causado à sociedade. Aí reside, pois, para ele, a proporcionalidade ${ }^{23}$.

Ressalta, no tocante à sanção, que

o fim da pena, pois, é apenas o de impedir que o réu cause novos danos aos seus concidadãos e demover os outros de agir desse modo.

É, pois, necessário selecionar quais as penas e quais os modos de aplicá-las, de tal modo que, conservadas as proporções, causem impressão mais eficaz e mais duradoura no espírito dos homens, e a menos tormentosa no corpo do réu ${ }^{24}$.

Podem-se perceber duas claras tendências, até então díspares, presentes em seu texto: o humanismo e o utilitarismo. O primeiro se evidencia, precipuamente, na execração às penas cruéis, infamantes e desnecessárias, enquanto o segundo é o critério determinante da racionalidade de um ato. Para ele a utilidade de um ato é sopesada pelo seu executor, por meio de critérios de prazer e dor, sendo isso que determinará a opção por sua realização ou não ${ }^{25}$.

século XVIII. Tal desavença originou-se do casamento do jovem com Teresa de Blasco, união não desejada pelo genitor.

${ }^{22}$ ANITUA, Gabriel Ignacio. Histórias dos pensamentos criminológicos. Tradução de Sérgio Lamarão. Rio de Janeiro: Revan, 2008. p. 160.

${ }^{23}$ "A única e verdadeira medida do delito é o dano causado à nação, errando, assim, os que pensavam que a verdadeira medida do delito era a intenção de quem o comete". Cf. BECCARIA, Cesare. Dos delitos e das penas. Tradução de J. Cretella Jr. e Agnes Cretella. 3. ed. São Paulo: Revista dos Tribunais, 2006. p. 34.

${ }^{24}$ BECCARIA, Cesare. Dos delitos e das penas. Tradução de J. Cretella Jr. e Agnes Cretella. 3. ed. São Paulo: Revista dos Tribunais, 2006. p. 43.

${ }^{25}$ Com sua morte essas duas tendências separaram-se novamente conformando a Escola Penal Liberal e a Escola Penal Utilitária. Cf. SALDAÑA, Quintiliano. Nova Criminologia. Tradução de Alfredo Ulson e V. de Alcântara Carreira. 2. ed. Campinas: Russel, 2006. 
Fato é que "Cesare Beccaria completa o sentimento de humanidade com a razão jurídica, e foi ele que transformou as bases empíricas da punição em bases racionais da convicção íntima"26.

Destaca-se em sua doutrina a especial atenção dada à prevenção de novos delitos, 0 que, segundo ele, poderia se alcançar por meio de uma boa legislação, incrementando-se o interesse dos magistrados pela observância das normas e desinteresse pela corrupção, bem como com a concessão de prêmios aos pensadores objetivando, com isso, incentivar a produção de boas ideias na seara penal ${ }^{27}$.

Acreditava ainda que apenas leis boas seriam capazes de reduzir a interferência do rei nas decisões penais e limitar a atividade do magistrado ao simples exercício lógico de enquadrar a premissa menor - fato concreto - à premissa maior - norma jurídica abstrata.

Muitos dos princípios expostos nessa obra serviram como essência da Escola Clássica de pensamento penal e criminológico que mais tarde surgiria, conformando Beccaria seu primeiro período.

Assim é que é ele por muitos considerado o primeiro pensador da Criminologia.

Importante destacar que a Escola Clássica não nasce de forma organizada, pela intenção de alguns precursores com afinidade e identidade de pensamentos. Ao revés, trata-se de uma classificação que se forma apenas com o surgimento de um novo modo de pensar a Criminologia, a ela contraposto, como denominação dos que com ela não coadunavam, os quais formavam a Escola Positivista.

Em decorrência disso, pode-se notar nos criminólogos clássicos um grupo com ideias centrais coesas, apresentando, porém, diversidades em relação a inúmeras outras questões $^{28}$.

É a identidade de método, qual seja, o racional, que permite a unificação dos diversos pensadores e pensamentos nesse grupo.

\footnotetext{
${ }^{26}$ SALDAÑA, Quintiliano. Nova Criminologia. Tradução de Alfredo Ulson e V. de Alcântara Carreira. 2. ed. Campinas: Russel, 2006. p. 59.

${ }^{27}$ BECCARIA, Cesare. Dos delitos e das penas. Tradução de J. Cretella Jr. e Agnes Cretella. 3. ed. São Paulo: Revista dos Tribunais, 2006.

${ }^{28}$ É certo que dentro da ideologia hoje chamada de Clássica se produzem concepções diversas acerca do contratualismo, do utilitarismo, bem como de outras inúmeras questões. O objetivo deste item não é apresentá-las de forma pormenorizada, identificando-se seus precursores. O que se busca com a explanação é ir além de todos esses autores isoladamente considerados e identificar a ideologia que impulsionou tantas mudanças no sistema dogmático penal e na Criminologia. Assim, a ideia da utilização do termo escola contempla um recurso didático, não a intenção de homogeneizar, de maneira simplista, o pensamento desenvolvido durante mais de um século.
} 
Dentre seus principais representantes pode-se destacar o já citado Beccaria, bem como Feuerbach, Bentham, Blackstone, Rossi, Carrara, Mello Freire e Romilly.

De maneira uniforme, buscam os clássicos explicações para o crime, utilizando-se da exaltação da razão que se construiu neste período, abandonando-se, assim, as superstições como mecanismos de explicação do desconhecido ou do não querido.

Pretendem proteger o delinquente em diversas esferas: sua vida, com a abolição da pena de morte; seu corpo, com a extinção das torturas e das penas corporais; sua honra, com o fim das penas infamantes; sua fortuna, com a abolição do confisco, bem como sua família, com a proibição da transcendência penal e sua substituição pela pessoalidade da pena $^{29}$.

Defendem também, tal qual Beccaria, leis escritas, conformando o princípio da legalidade, a extinção das arbitrariedades dos nobres e magistrados, a proporcionalidade das penas $^{30}$, o livre-arbítrio dos homens, sua racionalidade pura, bem como a teorização do delito como um ente jurídico.

A Escola Clássica não reconhecia a influência de fatores endógenos ou exógenos na prática delitiva $^{31}$. Não se falava, assim, em causas determinantes do comportamento proibido. O cometimento de um crime, pois, decorria de uma decisão livre e racional do infrator, permitida pelo livre-arbítrio que o guiava.

Por sua vez, enuncia o conceito de livre-arbítrio que o homem é dotado da faculdade de agir sem motivos ou finalidades diversos de sua própria ação ${ }^{32}$.

Acreditava-se numa racionalidade pura do indivíduo, o qual teria o poder de escolha em relação a sua ação lícita ou ilícita, sendo por isso o criminoso tratado de forma severa e inflexível.

\footnotetext{
${ }^{29}$ SALDAÑA, Quintiliano. Nova Criminologia. Tradução de Alfredo Ulson e V. de Alcântara Carreira. 2. ed. Campinas: Russel, 2006.

${ }^{30}$ Note-se que é bastante complexa a tarefa de estabelecer uma correlação proporcional entre os delitos e as penas, tendo em vista que não há critérios objetivos para se auferir a gravidade de um crime ou mesmo saber se ele é mais gravoso que outro.

${ }^{31}$ NICODEMOS, Carlos. Menoridade Penal: inimputabilidade x impunidade: desafios para o próximo século. Revista da Faculdade de Direito de Valença, Valença, v. 2, n. 2, p. 106-114, dez. 1999.

${ }^{32}$ Essa compreensão do homem como ente livre relaciona-se com o pensamento jurídico-cristão, base da civilização Ocidental. Em atenção à sua suposta semelhança com a divindade, acreditava-se que apenas Deus e o homem eram capazes de livremente discernir entre o bem e o mal. Ninguém mais. São Tomás de Aquino, concordando com essa concepção, afirmava também que a liberdade era um dom concedido ao homem, por Deus. Quase meio século mais tarde, Immanuel Kant demonstra ainda a vivacidade desse entendimento ao defender, em sua famosa obra Crítica da Razão Pura, a liberdade do homem e de suas decisões. Pode ainda mencionar-se, agora no campo das ciências penais, a concepção livre-arbitrista de Carrara, como fundamento da responsabilidade moral do homem. Cf. FONTALVO, Jorge Restrepo. Criminología: un enfoque humanístico. 3. ed. Colômbia: Temis, 2002.
} 
Defende-se que criminoso é igual a todos os demais seres humanos, sendo este o fundamento da racionalidade pura proposta pelos clássicos. Optou pela prática criminosa de forma racional, assim como o faz um cidadão em relação a uma conduta lícita.

Importante que se destaque que ao entender a decisão criminosa como um ato meramente racional, igual para todos os homens, os clássicos se esquivam da discussão acerca da influência da desigualdade social no contexto delitivo, o que favorecia a posição burguesa de classe detentora dos meios de produção e da riqueza.

Vê-se, então, que se pregava a igualdade entre todos os membros da sociedade, no tocante à sua racionalidade, razão pela qual seriam todos também adeptos do mesmo contrato social, sem, entretanto, justificar-se a desigualdade social e a extremada proteção da propriedade privada. Nesse sentido, "se bem os homens haviam sido iguais no estado de natureza, na sociedade não podiam sê-lo; tinham que conservar a autoridade e a subordinação",33.

Acreditava-se que o indivíduo sopesava o prazer e a dor decorrentes do ilícito, efetuando um cálculo racional dos benefícios esperados em cotejo com os prejuízos que porventura adviriam de sua ação, sendo este o mecanismo que encerra a concepção clássica de homem.

Partem do princípio fundamental, falso, de que a vontade livre do indivíduo é a causa única do cometimento do crime e de que todos os imputáveis são iguais e agem de acordo com um mesmo mecanismo racional ${ }^{34}$.

Por isso, mister para a Escola a diferenciação entre imputáveis e inimputáveis. Não havendo livre-arbítrio, não há que se falar em imputabilidade nem em responsabilidade, cogitando-se apenas a aplicação de medidas profiláticas.

A responsabilidade penal do criminoso se funda em sua responsabilidade moral, a qual está baseada no livre-arbítrio. Nesse sentido, "o criminoso é penalmente responsável, porque tem a responsabilidade moral e é moralmente responsável porque possui o livrearbítrio" $" 35$.

\footnotetext{
${ }^{33}$ TAYLOR, Ian; WALTON, Paul; YOUNG, Jack. La Nueva Criminología: contribución a una teoria social de la conducta desviada. Tradução de Adolfo Crosa. Buenos Aires: Amorrortu, 1997. p. 21-22.

${ }^{34}$ ARAGÃO, Antonio Moniz Sodré de. As três escolas penais: clássica, antropológica e crítica. 8. ed. Rio de Janeiro: Freitas Bastos, 1977.

${ }^{35}$ ARAGÃO, Antonio Moniz Sodré de. As três escolas penais: clássica, antropológica e crítica. 8. ed. Rio de Janeiro: Freitas Bastos, 1977, p. 59.
} 
Para chegar as suas conclusões utiliza um método lógico-dedutivo e apriorístico. A já citada racionalidade pura dos homens, na tomada de decisões, renega a um segundo plano qualquer análise empírica que possa ser feita dos homens.

Para os clássicos, que sentido haveria em se estudar aspectos particularizados dos indivíduos, tais como sua relação familiar ou condição econômico-social, por exemplo, se o processo que define as ações lícitas ou ilícitas é o mesmo para todos? Certamente esse interesse era propositadamente inexistente...

Evidencia-se entre os clássicos uma preocupação precípua com o fato em si, olvidando-se da pessoa que o praticou, seu autor, e de suas motivações individuais.

O crime não é visto como um fenômeno social ou patológico, mas como uma abstração jurídica, um ente jurídico, de acordo com a formulação de Francesco Carrara.

Merece destaque sua obra Programa do Curso de Direito Criminal, publicada no ano de 1859, período que identifica o segundo momento e ponto ápice da Escola.

Por ser um ente jurídico, o delito deveria ser estudado como uma abstração, desligado da análise da pessoa do delinquente.

Formulou Carrara um conceito transcendente, negando-se o autor a compreender o crime como um ente de fato, vinculado a aspectos da realidade.

Não há consenso entre os clássicos acerca da finalidade atribuída à pena criminal.

Beccaria e Bentham, representantes de uma primeira fase da Escola, defendiam o fim de prevenção geral e especial negativa das sanções. Já num segundo momento, Carrara juntamente com os filósofos Kant e Hegel, exaltavam a função da pena como mera retribuição do mal causado pelo criminoso ${ }^{36}$. Acreditavam que seu objetivo último era fazer cessar o perigo social que certamente adviria da impunidade pela infração à norma ${ }^{37}$.

Não obstante a existência destas diferenças de pensamento, predominava uma concepção consensual da sociedade, na qual os valores nela vigentes emanavam de uma instituição suprema e eram, portanto, aceitos por todos.

Ante todo o explanado acerca da Escola Clássica, pode-se concluir ser ela uma teoria do controle social. Fixa os parâmetros de acordo com os quais o Estado deve reagir

\footnotetext{
${ }^{36}$ Importante perceber que o conceito da pena como retribuição, que se mantêm no discurso jurídico contemporâneo, remonta a este momento histórico, como um conceito da burguesia européia central e nórdica do século XVIII, estreitamente vinculado a concepção da sociedade em conformidade com as teorias contratualistas. Cf. ZAFFARONI, Eugenio Raúl. Criminología: aproximación desde un margen. Colômbia: Temis, 1993.

37 O estudo pormenorizado das teorias justificadoras das penas e das medidas socioeducativas será desenvolvido no último capítulo desta obra.
} 
frente ao delinquente, os atos que permitem que quem os pratique seja qualificado como delinquente e cria a base social do Direito Penal, tudo isso com o apoio da ascendente burguesia $^{38}$.

Ademais, os clássicos adotam uma posição crítica em relação ao Estado e a nobreza, estando, por isso, relacionada sua concepção criminológica com a questão política.

Mas que ninguém se engane com uma aparente benevolência em relação aos criminosos e a redução do controle penal.

Foucault analisa o verdadeiro objetivo da reforma ao pregar que não pretende ela uma organização mais equitativa do poder de punir, mas sim estabelecer uma nova economia dele, distribuí-lo de forma melhor, de modo que ele alcance todo o corpo social $^{39}$.

Assim, em suas palavras, as grandes metas eram

\begin{abstract}
fazer da punição e da repressão das ilegalidades uma função regular, coextensiva à sociedade; não punir menos, mas punir melhor; punir talvez com uma severidade atenuada, mas punir com mais universalidade e necessidade; inserir mais profundamente no corpo social o poder de punir $^{40}$.
\end{abstract}

A humanização dos castigos visa, na verdade, a moderar os efeitos de sua aplicação sobre a instância que o aplica, a proporção entre o crime e a pena não tem por base sua gravidade, mas sim a influência que o ato tem sobre o pacto social, razão pela qual a gravidade da pena leva em conta a possibilidade de repetição do crime ${ }^{41}$.

Seguindo o raciocínio clássico, o criminoso, ao conscientemente violar o contrato social ao qual anuiu anteriormente, se torna um inimigo de todo o corpo social. Todos e inclusive ele aceitaram as mesmas regras, entre elas a punição.

Zaffaroni identifica uma ideologia classista por detrás da ideia de contrato. A reparação inerente à violação do contrato só pode ser realizada pelos pobres por meio de sua força de trabalho, único bem que têm a oferecer. Por isso, nesses discursos que se iniciam entre a última metade do século XVIII e início do XIX, tem-se a generalização da privação da liberdade como pena ${ }^{42}$.

\footnotetext{
${ }^{38}$ TAYLOR, Ian; WALTON, Paul; YOUNG, Jack. La Nueva Criminología: contribución a una teoria social de la conducta desviada. Tradução de Adolfo Crosa. Buenos Aires: Amorrortu, 1997.

${ }^{39}$ FOUCAULT, Michel. Vigiar e punir. Tradução de Raquel Ramalhete. 32. ed. Petrópolis: Vozes, 1987.

${ }^{40}$ FOUCAULT, Michel. Vigiar e punir. Tradução de Raquel Ramalhete. 32. ed. Petrópolis: Vozes, 1987. p. 70.

${ }^{41}$ FOUCAULT, Michel. Vigiar e punir. Tradução de Raquel Ramalhete. 32. ed. Petrópolis: Vozes, 1987.

${ }^{42}$ ZAFFARONI, Eugenio Raúl. Criminología: aproximación desde un margen. Colômbia: Temis, 1993.
} 
Nesse novo contexto de compreensão da sociedade e da punição, o ato criminoso a atinge por inteiro, devendo todos reagir. Agora são todos contra o criminoso ${ }^{43}$.

\subsection{FASE SEMI-CIENTÍFICA}

A Escola Antropológica Italiana ${ }^{44}$ nasce no século XIX $^{45}$ e se erige enquanto forma de pensamento diametralmente oposta a anteriormente reinante, tendo em vista a falência dos postulados por esta formulados, que culminaram com o aumento e a diversificação da criminalidade $^{46}$. Surge também como produto do momento histórico em que se consolida, no qual as transformações ocorridas no seio estatal indicavam a tomada de uma postura cada vez mais intervencionista, econômica e socialmente ${ }^{47}$.

Assim,

a emergência da Escola Positiva - e da Criminologia - responde, pois, a uma redefinição interna da estratégia do poder punitivo, somente admissível na ultrapassagem do Estado de direito liberal para o Estado de Direito social ou intervencionista ${ }^{48}$.

Ademais, após o questionamento das concepções absolutistas pela Escola Clássica, na luta travada entre burguesia e nobreza, restava agora a construção de uma ideologia que permitisse a consolidação da nova ordem social, papel assumido pela Escola Positivista ${ }^{49}$.

${ }^{43}$ FOUCAULT, Michel. Vigiar e punir. Tradução de Raquel Ramalhete. 32. ed. Petrópolis: Vozes, 1987.

${ }^{44}$ Refere-se também a Escola pelos nomes de Positivismo Naturalístico, Positivismo Criminológico, Positivismo Sociológico ou Positivismo Científico. Cf. ANDRADE, Vera Regina Pereira de. A ilusão da segurança jurídica: do controle da violência à violência do controle penal. 2. ed. Porto Alegre: Livraria do Advogado, 2003.

${ }^{45}$ Entre os séc. XVIII e XIX surgiu uma escola denominada Cartográfica que é considerada para alguns autores uma ponte entre os pensamentos Clássico e Positivista e para outros o embrião da moderna Sociologia Criminal. Dirigia sua ênfase à relevância das estatísticas na abordagem do fenômeno criminal. No entanto, sua importância foi bastante mitigada pela repercussão da teoria de Lombroso. Sobre o assunto ver: GARCÍA-PABLOS DE MOLINA, Antonio. Criminologia: uma introdução a seus fundamentos teóricos. Tradução de Luiz Flávio Gomes. São Paulo: Revista dos Tribunais, 1992 e SHECAIRA, Sérgio Salomão. Criminologia. 2. ed. rev. São Paulo: Revista dos Tribunais, 2008.

${ }^{46}$ DIAS, Jorge de Figueiredo; ANDRADE, Manuel da Costa. Criminologia: o homem delinqüente e a sociedade criminógena. 2 reimp. Coimbra: Coimbra Editora, 1997.

${ }^{47}$ Do mesmo modo que a Escola Clássica, o Positivismo também remonta suas origens à Ilustração. No século XIX, com a formação do Estado Liberal, algumas correntes iluministas se separam e cada um de seus enfoques originou um dos pensamentos mencionados. Nesse sentido: Bustos Ramírez, Juan. Criminología y evolución de las ideas sociales. In: BERGALLI, Roberto; ; MIRALLES, Teresa. El Pensamiento Criminológico: un análisis crítico. Bogotá: Temis, 1983. p. 27-48. v. 1.; SHECAIRA, Sérgio Salomão. Criminologia. 2. ed. rev. São Paulo: Revista dos Tribunais, 2008 e ANDRADE, Vera Regina Pereira de. A ilusão da segurança jurídica: do controle da violência à violência do controle penal. 2. ed. Porto Alegre: Livraria do Advogado, 2003.

${ }^{48}$ ANDRADE, Vera Regina Pereira de. A ilusão da segurança jurídica: do controle da violência à violência do controle penal. 2. ed. Porto Alegre: Livraria do Advogado, 2003. p. 71.

${ }^{49}$ Nesse sentido: Zaffaroni, Eugenio Raúl. Criminología: aproximación desde un margen. Colômbia: Temis, 1993 e BUSTOS RAMÍREZ, Juan. Criminología y evolución de las ideas sociales. In: BERGALLI, Roberto; 
Para Andrade pode-se apontar que toda crítica perpetrada pela novel Escola está centrada em duas grandes dicotomias: individual x social e racionalismo x empirismo.

O primeiro confronto explica-se porque, enquanto a Escola Clássica estava construída em torno da defesa do delinquente, ou seja, da sua proteção contra a ingerência estatal em sua esfera de direitos individuais, a Escola Antropológica Italiana busca resgatar o social antes esquecido, elevando o fim de defesa da sociedade contra os criminosos.

A segunda discrepância refere-se à metodologia de estudo aplicada por cada qual das Escolas. Os clássicos, de orientação filosófica, utilizavam-se da abstração para entender o fenômeno criminal, precipuamente o crime. Em contrapartida, os positivistas, de orientação científica, optaram por uma investigação empírica, centrada na pessoa do delinquente $^{50}$.

Surge então uma proposta de busca das causas da criminalidade, da etiologia do delito, partindo-se da ideia de que os criminosos eram seres anormais, os quais se diferenciavam substancialmente dos indivíduos comuns, ditos normais, inclusive no tocante às suas características físicas. Desenvolve-se, pois, uma concepção patológica do crime e exalta-se o caráter diferencial de seu autor.

Daí estar a Criminologia deste momento interligada às ciências antropológicas e sociológicas.

Os criminosos, "pelas suas anomalias orgânicas e psíquicas, hereditárias e adquiridas, constituem uma classe especial, uma variedade da espécie humana"51.

Assim, resta evidente o combate veemente à premissa de igualdade entre os seres criminosos e os não criminosos, proposta pelos clássicos.

Como salientado, total inversão metodológica em relação à Escola anterior ocorre, transmudando-se de uma forma dedutiva de se analisar o crime para outra indutiva, empírica e causalista.

O atributo primordial do Positivismo encontra-se justamente na sua insistência na unidade do método científico, acreditando-se que as premissas e instrumentos utilizados na apreensão do mundo físico serviriam também para o estudo dos homens e da sociedade como um todo. Por essa razão, propuseram o uso de métodos para quantificar o 48. v. 1 .

; MIRALlES, Teresa. El Pensamiento Criminológico: un análisis crítico. Bogotá: Temis, 1983. p. $27-$

${ }^{50}$ ANDRADE, Vera Regina Pereira de. A ilusão da segurança jurídica: do controle da violência à violência do controle penal. 2. ed. Porto Alegre: Livraria do Advogado, 2003.

${ }^{51}$ ARAGÃO, Antonio Moniz Sodré de. As três escolas penais: clássica, antropológica e crítica. 8. ed. Rio de Janeiro: Freitas Bastos, 1977. p. 138. 
comportamento humano, ressaltaram a objetividade e a neutralidade que devem dirigir o cientista em seus estudos e a natureza causal do agir dos sujeitos ${ }^{52}$.

Assim, para criar um estereótipo do criminoso, utilizavam-se de métodos quantitativos $^{53}$, tipologia e realizava-se uma pesquisa empírica-naturalista, propondo, dessa forma, um modelo causal-explicativo de sua "ciência".

No entanto, não se pode afirmar que a Escola inovou nesse aspecto. O Positivismo beneficiou-se de estudos etiológicos precursores de outras áreas do saber, tais como das teorias fisionomistas, frenológicas e psiquiátricas ${ }^{54}$.

Nesse contexto, o crime passa a ser considerado um fato causalmente determinado. Ocorre que, a respeito de suas causas determinantes, não consentiam seus principais representantes.

Considera-se Cesare Lombroso o fundador do Positivismo, por meio da publicação de sua obra L'Uomo Delinquente, no ano de 1876. No entanto, o núcleo fundamental desse novo modo de pensar englobava também seus discípulos Enrico Ferri e Rafaelle Garófalo $^{55}$.

A despeito da similitude de seus pensamentos, que permitiram a formação de uma escola bem mais coesa do que a anterior, cada qual deles elevava a importância de uma vertente de análise na etiologia do crime, apresentando suas doutrinas formas um pouco diversas de pensar o fenômeno criminal. Lombroso privilegiou o aspecto antropológico, Ferri o sociológico e Garófalo o psicológico.

O paradigmático livro de Lombroso apresenta duas proposições fundamentais: a aplicação dos métodos da ciência da natureza ao fenômeno delinquencial e o estudo concreto do delinquente por meio de sua observação clínica ${ }^{56}$.

\footnotetext{
52 TAYLOR, Ian; WALTON, Paul; YOUNG, Jack. La Nueva Criminología: contribución a una teoria social de la conducta desviada. Tradução de Adolfo Crosa. Buenos Aires: Amorrortu, 1997.

${ }^{53}$ Importante salientar a relatividade que se deve atribuir as estatísticas criminais, uma vez que elas não representam a realidade criminal, em decorrência, principalmente, da cifra negra a elas inerente.

${ }^{54}$ Sobre o assunto ver: DIAS, Jorge de Figueiredo; ANDRADE, Manuel da Costa. Criminologia: o homem delinqüente e a sociedade criminógena. 2 reimp. Coimbra: Coimbra Editora, 1997 e ARAGÃO, Antonio Moniz Sodré de. As três escolas penais: clássica, antropológica e crítica. 8. ed. Rio de Janeiro: Freitas Bastos, 1977.

${ }^{55}$ No tocante à colocação social dos autores tem-se que Lombroso era burguês, Ferri filho de um pequeno comerciante de tabaco, por isso diz-se que saiu do proletariado e Garófalo era nobre. Cf. FONTALVO, Jorge Restrepo. Criminología: un enfoque humanístico. 3. ed. Colômbia: Temis, 2002.

${ }^{56}$ COSTA, Álvaro Mayrink da. Criminologia. 3. ed. Rio de Janeiro: Forense, 1982.
} 
O autor não acreditava na independência e desenvolvimento do ser humano. Para ele o criminoso era um ser inferior, de constituição biológica atávica, e o delito por ele perpetrado representava mero sintoma de sua periculosidade.

Por isso desenvolveu a teoria do criminoso nato, central na Escola ora em análise $\mathrm{e}^{57}$.

Acredita o autor que o criminoso é um ser involuído, que traz consigo características de seus antepassados mais longínquos, o que evidenciaria seu desenvolvimento atávico ${ }^{58}$.

Via de regra, a cada geração que passa, mais civilizados são os seres nela nascidos. Ocorre que esse processo não se confirma em relação ao delinquente. Este, se pensa, herda características de antepassados involuídos, o que determina seus instintos bárbaros, sua ferocidade e insensibilidade moral ${ }^{59}$.

Dentro desse contexto, não se fala mais em livre-arbítrio ou atitude racional do sujeito dirigida à prática criminosa, já que ela é produto de forças genéticas que compelem o indivíduo a praticar o mal.

Essa teorização faz com que Lombroso entenda o criminoso com um ser sem correção.

Buscando elidir as críticas efetivadas contra sua obra, no decorrer de sua trajetória Lombroso modifica sua tese acrescentando como causas da criminalidade também a epilepsia e, num segundo momento, a loucura moral.

Para ele o louco e o criminoso diferem apenas pelo grau de suas regressões atávicas, não existindo diferença qualitativa entre ambos.

$\mathrm{O}$ autor supervaloriza aspectos estéticos e da fala dos indivíduos, elevando-os à categoria de representações do criminoso.

Nesse sentido, crê na feiúra dos delinquentes, na sua usual tatuação corporal, demonstração da sua insensibilidade física e menor percepção das sensações dolorosas,

\footnotetext{
${ }^{57}$ A tese do criminoso nato, marco da teoria criada por Lombroso, em realidade não foi um invenção sua. Um dos primeiros a defender a existência de um ser já "nascido para o crime" foi o espanhol Mariano Cubí y Soler.

${ }^{58}$ Atavismo é a transmissão genética de caracteres físicos e psíquicos de antecedentes bastante remotos do nascente, e não dos genealogicamente mais próximos. Cf. SOARES, Orlando. Criminologia. Rio de Janeiro: Freitas Bastos, 1986.

${ }^{59}$ ARAGÃO, Antonio Moniz Sodré de. As três escolas penais: clássica, antropológica e crítica. 8. ed. Rio de Janeiro: Freitas Bastos, 1977.
} 
bem como na utilização de gírias por parte desses sujeitos. E assim, "a prova da criminalidade agora se torna um problema de evidencia externa" ${ }^{, 60}$.

Claramente, suas ideias culminaram numa estereotipização do delinquente. Como relata Zaffaroni

\begin{abstract}
hoje sabemos que os estereótipos operam como reitores do processo seletivo dos sistemas penais, mas também sabemos que nem sempre o fazem de forma perfeita, senão que são um 'reitor geral', o que, naturalmente, também ocorria na época lombrosiana ${ }^{61}$.
\end{abstract}

A despeito de haver ressaltado as causas individuais de determinação do delito, Lombroso não negou a influência do meio social e até atribuiu importância à prevenção geral, mormente à educação.

Por diversos autores ele, e não Beccaria, é considerado o fundador da Criminologia ${ }^{62}$.

Ferri, por sua vez, recebe o mérito de ter empregado, pela primeira vez, no ano de 1892, a expressão "Sociologia Criminal" como título substitutivo na $3^{\mathrm{a}}$ edição da obra $O s$ novos horizontes do Direito e do Processo Penal ${ }^{63}$.

Resultado, pois, de sua concepção sociológica do crime, aliada à biológica, característica da Escola, considerou que o delito decorre da contribuição de fatores individuais, físicos e sociais, o que frontalmente contraria a tese antropológica formulada por Lombroso, o qual, como se viu, considera o ato ilícito como produto de uma anomalia individual.

Decorrência dessa tríade causal determinante do crime, Ferri criou uma classificação multifatorial dos delinquentes em nato, louco, habitual, ocasional e passional, considerada a mais bem desenvolvida pela Escola.

Natos são os criminosos com as mais acentuadas anomalias orgânicas e psíquicas, o que os tornam insensíveis moralmente, imprudentes, impulsivos e incorrigíveis. Seus principais representantes são o assassino e o ladrão.

\footnotetext{
${ }^{60}$ TANNEMBAUM, Frank. Crime and the community. Nova Iorque: Columbia University Press, 1951. p. 5.

${ }^{61}$ ZAFFARONI, Eugenio Raúl. Criminología: aproximación desde un margen. Colômbia: Temis, 1993. p. 165.

${ }^{62}$ Nesse sentido: COSTA, Álvaro Mayrink da. Criminologia. 3. ed. Rio de Janeiro: Forense, 1982; ANITUA, Gabriel Ignacio. Histórias dos pensamentos criminológicos. Tradução de Sérgio Lamarão. Rio de Janeiro: Revan, 2008 e JIMÉNEZ DE ASÚA, Luis. Tratado de Derecho Penal. 5. ed. Buenos Aires: Losada, 1950. v. 2.

${ }^{63}$ A despeito de essa ser a opinião prevalente, aponta-se que tal expressão já teria sido utilizada no ano de 1889 como título de uma obra escrita por um outro discípulo de Lombroso chamado Napoleone Colajanni. Cf. ANITUA, Gabriel Ignacio. Histórias dos pensamentos criminológicos. Tradução de Sérgio Lamarão. Rio de Janeiro: Revan, 2008.
} 
Os criminosos loucos não podem ser uniformemente descritos, já que se compõem por uma diversidade de sujeitos com enfermidade mental.

Habituais são os adquiriram uma tendência criminal ao longo de sua vivência, não tendo essa postura uma base orgânica.

Ocasionais são os que delinquem impulsionados pelas oportunidades do meio. Se não fossem elas, certamente agiriam de forma diversa.

Os passionais, por fim, assemelham-se aos ocasionais, mas o que os levam a delinquir são as paixões, sua forte exaltação ${ }^{64}$.

Uma de suas grandes criações foi o sistema de substitutivos penais, inspirado em medidas preventivas enumeradas pela primeira vez por Jeremy Bentham. Ferri acreditava que a pena deveria ter estreita relação com o tipo do criminoso do qual se tratava, razão pela qual deveria haver penalidades mais severas - como a prisão - e sanções mais brandas a ela substitutas - entre elas a indenização pecuniária.

Ainda para Ferri o criminoso pode e deve ser responsabilizado por seus atos ilícitos devido ao fato de viver em sociedade, no que ele denomina de responsabilidade social. Isso, por si só, é que justifica o fato de um outro homem poder imputar a terceiro determinada sanção pela prática de uma conduta desviada.

Como forma de se defender a sociedade, crê ser mais eficaz a prevenção do que a repressão dos delitos, razão pela qual pugnou pelo emprego de medidas pré-delituais. Porém, sendo mister a aplicação da pena, esta deve servir como medida de tratamento do delinquente, no que hoje se convenciona a finalidade de prevenção especial positiva.

Garófalo foi quem primeiro tentou formular um conceito de delito atemporal e que pudesse se verificar universalmente, o que denominou de delito natural, consistente numa ofensa ao senso moral de piedade e probidade.

Considerava que afetavam a piedade os crimes contra a vida e saúde de outrem. Em contrapartida, atentavam contra a probidade os delitos contra a propriedade.

\footnotetext{
${ }^{64}$ A classificação feita por Ferri assemelha-se à desenvolvida por Lombroso numa das reformulações finais de seu pensamento. Importante mencionar que essa mudança, especialmente quando do reconhecimento da existência de criminosos ocasionais, deveu-se principalmente ao fato de ter-se deparado com criminosos cujos estereótipos criminais estavam ausentes. Assim, passou a defender que havia os delinquentes natos, por paixão, loucos e de ocasião. A grande diferença, pois, é que para Lombroso os delinquentes habituais não conformariam uma classe autônoma, mas comporiam a dos ocasionais. Já a classificação de Garófalo estava condicionada pela sua teoria do delito natural e os criminosos poderiam ser enquadrados nas categorias de assassinos, violentos, ímprobos e cínicos.
} 
Conforme mencionado em momento anterior, para ele, a anomalia que recaía sobre o delinquente não era patológica, como pregava Lombroso, mas sim psíquica ou moral. Na explanação de García-Pablos de Molina

trata-se de um déficit na esfera moral da personalidade do indivíduo, de base orgânica, endógena, de uma mutação psíquica (porém não de uma enfermidade mental) transmissível por via hereditária e com conotações atávicas e degenerativas ${ }^{65}$.

Desenvolveu de forma mais pormenorizada o estudo do castigo pregando que as penas deveriam ser adaptadas às características pessoais de cada criminoso, o que o levou ao extremo de defender a pena de morte, desconsiderando-se, assim, suas pretensas funções de retribuição, reeducação e prevenção. Também por isso a pena não precisaria respeitar a proporcionalidade com o fato que a gerou, devendo ela ser dura para proteger mais adequadamente a sociedade.

Garófalo criou ainda o conceito de temibilidade, que se compunha na perversidade constante e impulsionadora do delinquente e na quantidade do mal que se poderia temer de sua parte. Tal expressão foi mais tarde substituída pelo termo periculosidade.

Baseada, pois, a defesa social na temibilidade do agente, mister a existência de um critério para auferi-la. Assim, esta deveria ter por base a qualidade do ato antissocial e a natureza antissocial do agente.

Aquela se determinava pelo direito concretamente violado somado à análise principal dos motivos que levaram a tal violação. Na verdade a análise do ato em si era secundária, pois para os positivistas o crime era mero sintoma, expressão externa do mal já existente no sujeito. Relevância era dada aos motivos dessa prática, que serviriam para sua qualificação louvável ou criminosa ${ }^{66}$.

Já no tocante à natureza antissocial do agente, deveria ser analisada a categoria criminosa na qual o sujeito se enquadrava, o que se realizava por meio da perquirição de sua vida pregressa.

Note-se que ao princípio da proporcionalidade, medida de relação entre os delitos e as penas, proposto pelos clássicos, os positivistas contrapõem o princípio da temibilidade, que se preocupa com o grau de inadaptação do condenado à vida social ${ }^{67}$.

\footnotetext{
${ }^{65}$ GARCÍA-PABLOS DE MOLINA, Antonio. Criminologia: uma introdução a seus fundamentos teóricos. Tradução de Luiz Flávio Gomes. São Paulo: Revista dos Tribunais, 1992. p. 125.

${ }^{66}$ Essa investigação, por razões óbvias, não era realizada no tocante aos criminosos loucos e nos sujeitos ativos de crimes culposos.

${ }^{67}$ ARAG ̃̃O, Antonio Moniz Sodré de. As três escolas penais: clássica, antropológica e crítica. 8. ed. Rio de Janeiro: Freitas Bastos, 1977.
} 
Não se entenda aqui que a temibilidade é fundamento para aplicação de uma reprimenda, mas sim que ela é critério determinador de sua intensidade, tal qual o era a gravidade do delito para os clássicos.

Tal qual ocorria com os clássicos, os positivistas adotavam um modelo consensual de sociedade.

O direito posto é tratado como a representação dos valores harmonicamente aceitos pelo corpo social, pregava-se a defesa da sociedade vigente, e não sua crítica, e o delito era considerado um fenômeno individual, razão pela qual é por meio de sua análise que se perquiriam pelas causas do desvio.

Seu único objeto de estudo era, portanto, o homem. Mais especificamente, o homem "delinquente".

Note-se que o compromisso de desvendar as causas da criminalidade foi uma perspectiva utópica e irrealizável do Positivismo jurídico ${ }^{68}$. Ainda hoje nenhuma teoria conseguiu desvendá-las e não é possível que uma única linha de pensamento possa fazê-lo.

Isso porque um indivíduo pode ser impelido à prática criminosa por diversos fatores, sejam eles psicológicos, psiquiátricos ou sociais, não sendo possível uma única teorização prever de modo absoluto todas essas variáveis.

Podem ser identificados dois principais pontos de destaque no pensamento da Escola Positivista. Um deles pode ser sintetizado na sua ideologia político-criminal de tratamento do criminoso, porque permanece pulsando até hoje em determinadas questões penais $^{69}$, e o outro consiste no método que empregou e em sua pretensa cientificidade.

Fruto da dominante concepção positivista do criminoso, as penas impostas nesse período tinham precipuamente uma finalidade preventiva especial, por representarem o tratamento dispensado ao ser anormal.

Enfatizava-se o fim de prevenção do delinquente e a defesa da sociedade. No entanto, a realidade é que se inocuizava o indivíduo perigoso, protegendo-se assim a

\footnotetext{
${ }^{68}$ GARCÍA-PABLOS DE MOLINA, Antonio. La aportación de la Criminología. Eguzkilore. Cuaderno del Instituto Vasco de Criminología, San Sebastián, n. 3, p. 79-94, dez. 1989.

69 A ideologia de tratamento dos infratores, inaugurada pelos teóricos da Antropologia Criminal, foi referência de toda a ingerência histórico-legal no trato das crianças e adolescentes em conflito com a lei, a qual até hoje ainda se tenta desvincular da questão menoril. Tendo em vista a importância do tema, será ele tratado de forma detalhada no capítulo 3 do presente trabalho.
} 
sociedade dele. Legitimava-se o sistema como defesa social, por meio de um discurso intervencionista em relação aos seres maus, para a proteção dos seres bons ${ }^{70}$.

Notável a expansão do poder estatal contra o ser perigoso. Não se pretendia abrandar as penas, como intencionavam os clássicos, mas sim reduzir o cometimento de delitos por meio da extirpação dos criminosos.

Atinge-se, assim, o ápice da concepção utilitarista da sanção penal.

Desse entendimento das relações entre a sociedade e o criminoso se originaram as doutrinas de prevenção especial, em suas diversas manifestações, as quais foram fortemente empregadas também na repressão e "tratamento" das crianças e adolescentes desviados.

Os positivistas ocupavam-se do enfrentamento do delito e do delinquente de forma simbólica e formal. Tratava-se de um confronto direto entre o Estado e o autor do delito, este considerado de forma individualizada, independentemente das circunstâncias sociais que o envolviam. E nesse duelo entre o bem e o mal - Estado e delinquente, respectivamente - a vítima era neutralizada, olvidada ${ }^{71}$.

O presente modelo subordina a política criminal à penal, como se fosse esta a melhor e mais adequada forma de solução de conflitos, bem como fornece extremada relevância a ideia de intimidação como forma de tutela mais eficaz do comportamento social $^{72}$.

Defende que a prevenção ao delito está umbilicalmente ligada ao conhecimento de suas causas, mas, na realidade, "nem sequer cabe falar neste modelo criminológico e político criminal de 'prevenção' do delito, stricto sensu, de prevenção 'social', senão de 'dissuasão penal'",73.

\footnotetext{
${ }^{70}$ ANDRADE, Vera Regina Pereira de. A ilusão da segurança jurídica: do controle da violência à violência do controle penal. 2. ed. Porto Alegre: Livraria do Advogado, 2003.

71 GARCÍA-PABLOS DE MOLINA, Antonio. La prevención del delito: reflexiones en torno a la denominada 'prevención situacional'. In: José Luis Guzmán Dalbora (Coord.) El penalista liberal. Buenos Aires: Hammurabi, 2004.

${ }^{72}$ GARCÍA-PABLOS DE MOLINA, Antonio. La normalidad del delito y el delincuente. Revista de la Facultad de Derecho de la Universidad Complutense, Madri, n. 11, p. 325-346, jun. 1986.

${ }^{73}$ GARCÍA-PABLOS DE MOLINA, Antonio. La prevención del delito: reflexiones en torno a la denominada 'prevención situacional'. In: José Luis Guzmán Dalbora (Coord.) El penalista liberal. Buenos Aires: Hammurabi, 2004, p. 614.
} 
Ainda nas palavras de García-Pablos "a suposta diversidade do delinqüente não é senão um conhecido mecanismo tranqüilizador e auto-justificatório da sociedade que prefere sempre culpar a terceiros, para livrar a si mesma de sua parcela de culpa",74.

Triste perceber que a estereotipização do criminoso, criada pela Escola, ainda insiste em permear a compreensão de penalistas e, mais fortemente, do corpo social, sobre o citado sujeito. Assim, não há equívoco na ideia de que "é de Lombroso que se alimentam ainda hoje os reincidentes nos preconceitos antropológicos" ${ }^{\text {"75. }}$.

Relevante enfatizar que o grupo de amostragem da investigação positivista pessoas com as quais se realizavam os estudos empíricos pretensamente científicos circunscrevia-se à clientela dos presídios e manicômios, como se todos os criminosos se encontrassem ali e todos que ali estavam fossem realmente criminosos. Em outros termos, confundem-se reclusos e delinquentes, o que compromete severamente sua pretensão de cientificidade.

Nesse sentido, "as categorias se retroalimentavam, pois eram concebidas com base nas pessoas efetivamente detidas e seus aspectos justificavam que aqueles eram os 'tipos' que tinham de ser detidos"

Outrossim, nessa confusão entre recluso e criminoso

se fundamenta um tipo particular de ideologia cientificista, uma ideologia que confundirá a agressividade e a alienação do 'homem institucional' com sua intrínseca perversidade, uma ideologia que classificará e tipificará como modos diversos do ser criminoso tanto as formas de sobrevivência à realidade penitenciária quanto, num segundo momento, as adaptações aos modelos impostos, à violência classificatória sofrida pelos detentos ${ }^{77}$.

Interessa à escola apenas as ocorrências que podem ser empiricamente demonstradas, o que faz crer na prevalência da importância do método sobre o compromisso com a apreensão da realidade.

74 GARCÍA-PABLOS DE MOLINA, Antonio. La prevención del delito: reflexiones en torno a la denominada 'prevención situacional'. In: José Luis Guzmán Dalbora (Coord.) El penalista liberal. Buenos Aires: Hammurabi, 2004, p. 579.

${ }^{75}$ LYRA, Roberto; JÚNIOR, João Marcello de Araújo. Criminologia. 2 ed. Rio de Janeiro: Forense, 1990. p. 43.

${ }^{76}$ ANITUA, Gabriel Ignacio. Histórias dos pensamentos criminológicos. Tradução de Sérgio Lamarão. Rio de Janeiro: Revan, 2008. p. 305.

${ }^{77}$ MELOSSI, Dario; PAVARINI, Massimo. Cárcere e fábrica: as origens do sistema penitenciário: séculos XVI-XIX. Rio de Janeiro: Revan, 2006. p. 214. 
Não se olvide de que "é um problema essencial da filosofia a questão do método, porque quem não é filósofo carece de método todas as vezes que faz experiências. Tal é o caso de Lomboso",78.

Fica claro que pressupõem os positivistas que as normas penais são objetivamente observadas pelas agências encarregadas de seu cumprimento e que a clientela penal representa a realidade criminosa.

Assim, apresentam uma visão universalizante do delito e da reação social ao desconsiderar os componentes econômico-estruturais ou histórico-políticos que conformam o conceito de criminalidade ${ }^{79}$.

Também não se aceita nenhuma diferença entre a criminalidade adulta e a juvenil, posto que o indivíduo já é predisposto à prática ilícita, não havendo influência dos seus aspectos desenvolvimentais relacionados a idade.

Ademais, por não enfrentar a questão da reação social, a teoria positivista carece de alcance e simetria. Aquele porque omite os motivos impulsionadores da reação e não busca compreender a interpretação que o desviado faz da reação que contra ele se direciona. Esta porque divide o mundo em duas teorias do comportamento humano totalmente divergentes: o dos que cometem o delito e o dos que a ele reagem ${ }^{80}$.

Não se pode perder de vista que as classificações das ciências representam ideologias instrumentalizadas a serviço de interesses diferentes e estruturas de poder. Assim, o Positivismo, que enseja o nascimento da forma contemporânea da Criminologia, também representa o interesse do grupo dominante naquele dado momento, qual seja, o da burguesia europeia $^{81}$.

A realidade demonstra que após a ascensão burguesa, alcançada por meio dos paradigmas do contrato social, foi necessária a instrumentalização de um novo discurso que autorizasse a compreensão do poder dessa classe como algo natural, organicista. Assim "a ciência era o discurso que lhe permitia ridicularizar a ideia da sociedade como um

\footnotetext{
${ }^{78}$ SALDAÑA, Quintiliano. Nova Criminologia. Tradução de Alfredo Ulson e V. de Alcântara Carreira. 2. ed. Campinas: Russel, 2006. p. 233.

${ }^{79}$ BERGALLI, Roberto. Conflicto Social y control penal. Revista de la Facultad de Derecho Universidad Complutense, Madri, n. 11, p. 99-115, jun. 1986.

${ }^{80}$ TAYLOR, Ian; WALTON, Paul; YOUNG, Jack. La Nueva Criminología: contribución a una teoria social de la conducta desviada. Tradução de Adolfo Crosa. Buenos Aires: Amorrortu, 1997.

${ }^{81}$ ZAFFARONI, Eugenio Raúl. Criminología: aproximación desde un margen. Colômbia: Temis, 1993.
} 
'contrato', da mesma forma que ridicularizava os argumentos teocráticos. Essa foi a tarefa que teve a seu cargo o cientificismo positivista" ${ }^{, 82}$.

Ainda nesse sentido

apesar, pois, de que o espírito positivista pretende deslindar ciência de ideologia, relegando esta a um estado inferior do pensamento e indicando a ciência como o pilar da ordem social (da racionalidade) e a ideologia como a desordem (a irracionalidade), o pensamento positivista é pura ideologia, pois para ele a ordem social existente é um absoluto, não sujeito a discussão. Em suma, o positivismo é a ideologia da nascente sociedade burguesa industrial ${ }^{83}$.

De tudo isso se constata que a compreensão do significado de ciência está estritamente vinculada ao poder. Não se pode negar também que seja ela parcialmente política.

Impossível defender, nesse momento histórico, a existência de uma Criminologia autônoma, desvinculada do Direito Penal e de sua dogmática jurídica. Isso porque, como já se viu, para os positivistas criminosos eram aqueles, e todos aqueles, selecionados pelas agências de controle dos delitos.

Percebe-se, pois, que não se pode falar em um objeto de estudo próprio da Criminologia, já que ela o tomava emprestado acriticamente do Direito Penal.

Essa dependência em relação à definição do próprio objeto de estudo da Criminologia coloca em séria dúvida o status científico de seu conhecimento ${ }^{84}$.

${ }^{82}$ ZAFFARONI, Eugenio Raúl. Criminología: aproximación desde un margen. Colômbia: Temis, 1993, p. 132.

${ }^{83}$ BUSTOS RAMÍREZ, Juan. Criminología y evolución de las ideas sociales. In: BERGALLI, Roberto; ; MIRALlES, Teresa. El Pensamiento Criminológico: un análisis crítico. Bogotá: Temis, 1983. v. 1. p. 32.

${ }^{84}$ Não acreditam na cientificidade da Escola Positivista: BARATTA, Alessandro. Criminologia e Dogmática Penal. Passado e futuro do modelo integral da Ciência Penal. Revista de Direito Penal, Rio de Janeiro, n. 31, p. 5-37, jan.Ijun. 1981; COSTA, Álvaro Mayrink da. Criminologia. 3. ed. Rio de Janeiro: Forense, 1982; MELOSSI, Dario; PAVARINI, Massimo. Cárcere e fábrica: as origens do sistema penitenciário: séculos XVI-XIX. Rio de Janeiro: Revan, 2006; BUSTOS RAMÍREZ, Juan. Criminología y evolución de las ideas sociales. In: BERGALLI, Roberto;___ _ MIRALLES, Teresa. El Pensamiento Criminológico: un análisis crítico. Bogotá: Temis, 1983. p. 27-48. v. 1; ZAFFARONI, Eugenio Raúl. Criminología: aproximación desde un margen. Colômbia: Temis, 1993 e ANITUA, Gabriel Ignacio. Histórias dos pensamentos criminológicos. Tradução de Sérgio Lamarão. Rio de Janeiro: Revan, 2008. Acreditam na cientificidade da Escola Positivista: FONTALVO, Jorge Restrepo. Criminología: un enfoque humanístico. 3. ed. Colômbia: Temis, 2002; DIAS, Jorge de Figueiredo; ANDRADE, Manuel da Costa. Criminologia: o homem delinqüente e a sociedade criminógena. 2 reimp. Coimbra: Coimbra Editora, 1997; GARCÍA-PABLOS DE MOLINA, Antonio. Criminologia: uma introdução a seus fundamentos teóricos. Tradução de Luiz Flávio Gomes. São Paulo: Revista dos Tribunais, 1992; ANDRADE, Vera Regina Pereira de. A ilusão da segurança jurídica: do controle da violência à violência do controle penal. 2. ed. Porto Alegre: Livraria do Advogado, 2003; GASSIN, Raymond. Criminologie. 3. ed. Paris: Dalloz, 1994; HERRERO, César Herrero. Criminologia. 2. ed. Madri: Dykinson, 2001 e CID MOLINÉ, José; LARRAURI PIJOAN, Helena. Teorías Criminológicas: explicación y prevención de la delincuencia. Barcelona: Bosh, 2001. 
Para que uma teoria qualifique-se como científica, mister que ela descreva adequadamente seu objeto de estudo ${ }^{85}$. Certamente, isso não se verifica na Criminologia positivista, uma vez que não se pode descrever corretamente algo que nem sequer é delimitado da maneira adequada.

Por isso é que ela é caracterizada como uma ciência infeliz ${ }^{86}$.

Nesse período, formava ela, juntamente com a Dogmática Penal e a Política Criminal, o modelo integrado da Ciência Penal, desenvolvido por Franz Von Liszt.

A Criminologia é, pois, considerada uma ciência auxiliar do Direito Penal. Sua função não é questioná-lo ou colocá-lo à prova por meio de seus embasamentos empíricos, componentes de sua metodologia de apreensão da realidade, mas sim legitimar suas bases axiológicas e seu funcionamento. Pode-se dizer aqui que é esse o contexto da relação primária entre Dogmática Jurídica e Criminologia ${ }^{87}$.

O que se evidencia aqui é uma suposta submissão da Criminologia em relação ao Direito Penal. Essa premissa, herança da Escola Positivista, ainda combatida e que ainda gera reflexos atualmente, é herança da seleção de um objeto de estudo já de antemão delimitado e contaminado pelo Direito Penal, conforme explanado anteriormente.

Assim, pode-se constatar acerca do pensamento positivista da Criminologia que ele contempla um caráter consensual da ordem social; baseia-se no caráter diferencial do delinquente em relação aos não criminosos, ou na patologia da personalidade criminosa; na disfuncionalidade do desvio; legitimidade e coerência da reação social; na dependência do saber criminológico e em sua função legitimadora do direito penal e do sistema penal como um todo ${ }^{88}$.

\subsection{CRIMINOLOGIA COMO CIÊNCIA}

A ciência apresenta três características principais, as quais permitem distingui-la de outras formas de conhecimento não-científicas. São elas: um conjunto de métodos e

${ }^{85}$ GARRIDO, Vicente; STANGELAND, Per; REDONDO, Santiago. Principios de Criminología. 2. ed. Valência: Tirant lo blanch, 2001.

${ }^{86}$ MELOSSI; PAVARINI, MELOSSI, Dario; PAVARINI, Massimo. Cárcere e fábrica: as origens do sistema penitenciário: séculos XVI-XIX. Rio de Janeiro: Revan, 2006.

${ }^{87}$ ANDRADE, Vera Regina Pereira de. A ilusão da segurança jurídica: do controle da violência à violência do controle penal. 2.ed. Porto Alegre: Livraria do Advogado, 2003.

${ }^{88}$ GARCÍA-PABLOS DE MOLINA, Antonio. La normalidad del delito y el delincuente. Revista de la Facultad de Derechode la Universidad Complutense, Madri, n. 11, p. 325-346, jun. 1986. 
instrumentos, aptos a produzir conhecimentos confiáveis e verificáveis, sobre um tema considerado importante para a sociedade ${ }^{89}$.

A Criminologia só conseguiu atingir esse status após mais de um século de seu surgimento, quando da sua identificação com a Sociologia Criminal norte-americana.

Fato é que, historicamente, o saber criminológico proveniente dos Estados Unidos esteve sempre mais vinculado à Sociologia do que ao Direito Penal, ao contrário das suas vertentes europeia e latino-americana.

É no citado país que, no início do século XX, se encontram as condições favoráveis para a afirmação de uma nova abordagem do pensar criminológico.

A decadência e pobreza disseminadas na Europa, após as grandes guerras, bem como a ascensão de regimes totalitaristas, fortaleceram os movimentos migratórios em direção a América do Norte.

Nesse período, o centro do poder político e econômico do Ocidente desloca-se do eixo europeu para o norte-americano. Pensadores de diversas partes do mundo migram para o país, o que, aliado à calmaria política lá encontrada, abre a possibilidade da estabilização de um novo campo de conhecimento. Ademais, os Estados Unidos contavam com uma base filosófica que tornaria possível a recepção das novas ideias e pensamentos ${ }^{90}$.

Nota-se, de início, uma total inversão no método de colheita dos dados relevantes, bem como dos conceitos aceitos e aplicados pela disciplina.

Conforme explanado, para a Escola Positivista o crime era considerado produto de uma patologia individual que deveria ser exterminada em nome do interesse supremo de proteção da sociedade de bem. Afirmava uma ideologia de defesa social como núcleo teórico e político fundamental do sistema repressivo.

Esse entendimento entrou em crise exatamente com o surgimento das teorias criminológicas de cunho sociológico, em meados da década de 1920.

A Sociologia Criminal, em contrapartida, passa a tratar o delito como um fenômeno social, não se limitando apenas a exaltar a influência do entorno para a determinação do comportamento delitivo ${ }^{91}$. Transforma em seu objeto principal o estudo das relações entre

${ }^{89}$ GARRIDO, Vicente; STANGELAND, Per; REDONDO, Santiago. Principios de Criminología. 2. ed. Valência: Tirant lo blanch, 2001.

${ }^{90}$ ANITUA, Gabriel Ignacio. Histórias dos pensamentos criminológicos. Tradução de Sérgio Lamarão. Rio de Janeiro: Revan, 2008.

${ }^{91}$ GARCÍA-PABLOS DE MOLINA, Antonio. Criminologia: uma introdução a seus fundamentos teóricos. Tradução de Luiz Flávio Gomes. São Paulo: Revista dos Tribunais, 1992. 
a sociedade e seus membros, por meio de métodos quantitativos ou qualitativos, na medida em que elas possam contribuir para o crime.

A grande inversão de pensamento repousa na percepção da influência ambiental na determinação da conduta, mecanismo estritamente sociológico, mormente quando nega a predestinação ao crime ${ }^{92}$.

Por tudo isso é que "o surgimento da sociologia não pode ser pensado fora desse mundo marcado pelo positivismo, tanto porque seguiria seus ditames quanto porque se oporia a suas reduções" $" 93$.

Ao cotejar ambas as concepções assevera Roxin que

\begin{abstract}
deixam o pobre fazer-se culpado, e então entregam-no ao castigo: esta é a política criminal da neutralização que combate o delinqüente eliminando-o como inimigo da sociedade. Mas, a partir do momento em que se reconhece a responsabilidade da sociedade por aquilo em que se tornaram os seus membros e isto não é entusiasmo filantrópico, mas uma perspectiva científico-social muito sóbria-, a sociedade tem de aceitar também o seu dever de reparar o delinqüente aquilo que nele se perdeu, ou seja, não deve 'combatê-lo' nem marginalizá-lo, mas aceitá-lo como sua parte integrante e ajudá-lo a converter-se naquilo que estaria ao seu alcance em condições mais favoráveis ${ }^{94}$.
\end{abstract}

As teorizações sociológicas da criminalidade partem de um modelo que relaciona os acontecimentos sociais a uma determinada teoria da sociedade, na qual pretendem inserir o agir criminoso 95 .

Embora diversas e distintas, pode-se identificar um pressuposto comum a todas elas: a ideia da sociedade como intrinsecamente criminógena, ou seja, do fenômeno criminal como uma forma normal de adaptação social ou individual ${ }^{96}$.

É possível perceber a ocorrência, durante a evolução da Sociologia Criminal americana, de um duplo entroncamento da disciplina: uma vertente europeia e outra norteamericana. A primeira é de tipo academicista e encontra-se estreitamente vinculada a Durkheim e sua elaboração da teoria da anomia. Já a segunda se identifica com a Escola de Chicago, a partir da qual surgem as demais teorias sociológicas, tais como as ecológicas, as

\footnotetext{
${ }^{92}$ COSTA, Álvaro Mayrink da. Criminologia. 3. ed. Rio de Janeiro: Forense, 1982.

${ }^{93}$ ANITUA, Gabriel Ignacio. Histórias dos pensamentos criminológicos. Tradução de Sérgio Lamarão. Rio de Janeiro: Revan, 2008. p. 405. Uma ruptura total com a corrente positivista ocorre apenas com o surgimento da teoria do labelling approach, a qual abandonou o enfoque etiológico da Criminologia, voltando sua atenção para o estudo das reações sociais ao delito.

${ }^{94}$ ROXIN, Claus. Problemas fundamentais de Direito Penal. Tradução de Ana Paula dos Santos et al. 3. ed. Lisboa: Vega, 1998. p. 86-87.

${ }^{95}$ GARCÍA-PABLOS DE MOLINA, Antonio. Tratado de Criminología. 2. ed. Valência: Tirant lo blanch, 1999.

${ }^{96}$ DIAS, Jorge de Figueiredo; ANDRADE, Manuel da Costa. Criminologia: o homem delinqüente e a sociedade criminógena. 2 reimp. Coimbra: Coimbra Editora, 1997.
} 
subculturais, da aprendizagem, interacionistas e críticas, que serão analisadas ainda no presente capítulo.

Apesar de, como já mencionado, as teorias sociológicas da Criminologia terem se erigido enquanto oposição ao pensamento positivista, durante suas análises será possível perceber que elas, em muitos aspectos, não conseguiram dele se desvincular ${ }^{97}$.

Também se notará a existência de uma relação de continuidade entre muitas delas, embora cada qual se foque em aspectos específicos da realidade social como explicativos da criminalidade. O que se quer demonstrar é que, exceto quando se verifica a inversão do paradigma da ciência, com o labelling approach, não ocorre uma brusca ruptura no momento da substituição de uma teoria por outra, especialmente porque as teorizações anteriores coadunam de um mesmo modelo consensual de sociedade. Fato é que as novas explicações sociológicas não só estão intimamente ligadas entre si, como também chegam a coexistir temporalmente e ajudam a preparar terreno para as modernas construções que as substituirão.

Naturalmente cada uma delas pressupõe um dado clima e uma situação espiritual, enquanto, por outro lado, trinta ou quarenta anos parecem ser o período médio correspondente ao ciclo duma teoria, isto é, o tempo com que a maior parte delas conta para atingir seu cume de popularidade e iniciar seu declínio, dando lugar a explicações mais condizentes com o contexto social em que se inserem ${ }^{98}$.

Pode-se entender, então, que "a Criminologia se fez lentamente, pelas mãos e penas de muitos, não do dia para a noite, mas, como é natural, ao passo dos séculos: cada nova corrente criminológica repousa sobre o terreno semeado por outras correntes" 99 .

Com o desenvolvimento da Criminologia e da Sociologia Criminal, bem como da corrente técnico-jurídica da Dogmática Penal, começa a entrar em crise o modelo integral da ciência penal, de acordo com o qual o conhecimento criminológico era considerado auxiliar ao dogmático. A desvinculação do objeto de ambas colaborou particularmente para que isso ocorresse.

\footnotetext{
${ }^{97}$ Por esta razão é que alguns classificam as novas teorias da Criminologia social, anteriores ao labelling approach, devem ser consideradas neopositivistas. Nesse sentido: GARCÍA-PABLOS DE MOLINA, Antonio. La normalidad del delito y el delincuente. Revista de la Facultad de Derecho de la Universidad Complutense, Madri, n. 11, p. 325-346, jun. 1986.

${ }^{98}$ MANNHEIM, Hermann. Criminologia Comparada. Lisboa: Calouste Gulbenkian, 1984. v. 2.

${ }^{99}$ FERRO, Ana Luiza Almeida. Robert Merton e o funcionalismo. Belo Horizonte: Mandamentos, 2004. p. 99.
} 
As novas teorias que surgem passam a questionar a hegemonia de alguns dos princípios antes compartilhados pelas duas ciências, o que impossibilita a coesão entre as temáticas ${ }^{100}$.

No entanto, o citado processo não foi simples. Foi somente na década de 1960, com a já mencionada mudança de enfoque ocorrida no seio das teorias sociológicas, que tal concepção pôde ser totalmente superada.

É apenas quando a Criminologia volta sua atenção para a violência institucional produzida pelo sistema de controle introduzido pelo Direito Penal que ela deixa de ser um saber auxiliar, para tornar-se crítico e externo a ele ${ }^{101}$.

Por todo o exposto até aqui acerca da evolução dos pensamentos criminológicos, pode-se constatar que na história da Criminologia "o século XIX foi o da Biologia, do indivíduo, e o século XX é o da Sociologia, da sociedade" $" 102$.

\subsubsection{Criminologia do Consenso}

Os pensamentos criminológicos se encarregam de criticar certa ordem de coisas, entre elas a ordem social. E antes de fazê-lo devem explicar sobre que condições elas se baseiam, como surgem, se reproduzem e se mantêm ${ }^{103}$.

Afirmar que uma sociedade é consensual supõe aceitar que seus membros conjugam dos mesmos valores e interesses e que o sistema penal, especialmente no campo legislativo, contém a declaração dos comportamentos que todos querem extirpar.

Como reflexo dessa identificação entre os cidadãos e as normas, a ordem social não é nem precisaria ser imposta.

\footnotetext{
${ }^{100}$ BARATTA, Alessandro. Criminologia e Dogmática Penal. Passado e futuro do modelo integral da Ciência Penal. Revista de Direito Penal, Rio de Janeiro, n. 31, p. 5-37, jan.Ijun. 1981.

${ }^{101}$ Andrade relata que mesmo tendo a Criminologia alcançado sua independência, sua histórica auxiliaridade se reflete hoje na residualidade de seu ensino nas cátedras de graduação e pós-graduação das faculdades de Direito. Insurgindo-se contra este fato, a autora relata a importância da matéria, nos seguintes termos: "ensinar Criminologias [...] é concorrer para a formação de uma consciência jurídica crítica e responsável, capaz de transgredir as fronteiras, sempre generosas, do sono dogmático, da zona de conforto do penalismo adormecido na labuta técnico-jurídica; capaz de inventar novos caminhos para o enfrentamento das violências (individual, institucional e estrutural ) e este talvez seja o melhor tributo que possam prestar ao Ensino e à formação profissional-cidadã. Cf. ANDRADE, Vera Regina Pereira de. Por que a criminologia (e qual criminologia) é importante no ensino jurídico? Carta Forense, São Paulo, n. 58, p. 22-23, mar. 2008. p. 23.

${ }^{102}$ LYRA, Roberto; JÚNIOR, João Marcello de Araújo. Criminologia. 2. ed. Rio de Janeiro: Forense, 1990. p. 37.

${ }^{103}$ ANITUA, Gabriel Ignacio. Histórias dos pensamentos criminológicos. Tradução de Sérgio Lamarão. Rio de Janeiro: Revan, 2008.
} 
Acredita-se, pois, na conformação de uma sociedade enquanto associação voluntária de pessoas, cujas regras de comportamento compartilham. São os valores fundamentais nela inscritos que determinam a identidade do sistema e asseguram a coesão social.

Sendo assim, não tem lugar, nessas sociedades, a luta pelo poder, uma vez que se considera ser ele exercido no interesse e na busca da satisfação de todos.

Não se postula que a ordem social seja baseada em um consenso geral em torno de determinadas crenças, mas sim que ela pode ser concebida em termos de tal consenso, sendo ele basilar para sua formação ${ }^{104}$.

Assim, pode ser identificada aqui a existência de meras tensões no sistema, não de conflitos estruturais em seu seio.

O Estado é tido como o protetor geral do interesse público. Representando os valores e interesses da sociedade como um todo, ele é o órgão chamado a resolver os pequenos desentendimentos que podem eventualmente surgir ${ }^{105}$.

O crime, conduta sujeita a ingerência estatal, é considerado a representação da negação dos valores vigentes na sociedade, a demonstração clara da discordância de um sujeito com a ordem pacificada.

Esse modelo, também denominado utópico ou teoria integradora da sociedade, apresenta algumas características essenciais, as quais, expostas aqui de maneira simplificada, visam apenas ao fornecimento de uma visão geral dessa concepção da coesão social.

Vislumbra que a sociedade compõe-se por meio de uma estrutura de elementos relativamente persistente e estável; que é uma estrutura de elementos bem integrada; que a todo elemento de uma sociedade se atribui uma particular função, a qual contribui para a manutenção do sistema; e que tem o consenso como base da estrutura social. Desse modo, evidenciam-se seus caracteres de estabilidade, integração, coordenação funcional e consenso $^{106}$.

\footnotetext{
${ }^{104}$ DAHRENDORF, Ralf. As classes e seus conflitos na sociedade industrial. Tradução de José Viegas. Brasília: Editora Universidade de Brasília, 1982.

${ }^{105}$ VOLD, George B.; BERNARD, Thomas J. Theoretical Criminology. 3. ed. Nova Iorque: Oxford University Press, 1986.

${ }^{106}$ DAHRENDORF, Ralf. As classes e seus conflitos na sociedade industrial. Tradução de José Viegas. Brasília: Editora Universidade de Brasília, 1982.
} 
Um modelo puro de consenso exclui toda a margem de alienação, mas exclui igualmente toda a possibilidade de mudança, tendendo para a ahistoricidade e para o imobilismo ${ }^{107}$.

Tal visão de mundo permeou a compreensão da Criminologia até meados da década de 1960. Todas as teorias que se desenvolveram anteriormente a esse marco coadunam de uma visão consensual das sociedades, qualificando-se, pois, como teorias criminológicas do consenso.

A visão consensual da sociedade foi questionada muitas vezes, mas é significativo que essas críticas tenham se tornado mais contundentes em momentos de incertezas políticas, ou mesmo quando os homens não estavam seguros acerca da estabilidade, permanência ou legitimidade dos ordenamentos sociais vigentes ${ }^{108}$.

De modo geral, elas aceitam o princípio do interesse social e do delito natural, de acordo com os quais a criminalidade é uma qualidade ontológica de certos comportamentos ou indivíduos e são homogêneos os valores e interesses protegidos pelo Direito Penal $^{109}$.

Inserem-se nesse marco as teorias da ecologia criminal, da associação diferencial, da anomia e das subculturas delinquentes. Embora existam, por vezes, significativas disparidades entre elas, têm em comum o fato de que, em todas, a existência de alguma perturbação ao consenso produz a criminalidade.

\subsubsection{Teoria da Ecologia Criminal}

A Escola de Chicago é considerada o berço da moderna Sociologia americana ${ }^{110}$. Nasceu na Universidade de Chicago, local onde foi inaugurado, no ano de 1892, o Departamento de Sociologia, um dos pioneiros na disciplina.

Nesse marco, sua primeira construção científica foi a teoria da ecologia criminal.

\footnotetext{
${ }^{107}$ DIAS, Jorge de Figueiredo; ANDRADE, Manuel da Costa. Criminologia: o homem delinqüente e a sociedade criminógena. 2 reimp. Coimbra: Coimbra Editora, 1997.

${ }^{108}$ TAYLOR, Ian; WALTON, Paul; YOUNG, Jack. La Nueva Criminología: contribución a una teoria social de la conducta desviada. Tradução de Adolfo Crosa. Buenos Aires: Amorrortu, 1997.

${ }^{109}$ BARATTA, Alessandro. Os direitos da criança e o futuro da democracia. In: do Direito no início do século XXI. Coimbra: Coimbra Editora, 1999.

${ }^{110}$ GARCÍA-PABLOS DE MOLINA, Antonio. Criminologia: uma introdução a seus fundamentos teóricos. Tradução de Luiz Flávio Gomes. São Paulo: Revista dos Tribunais, 1992.
} 
Em seu sentido original, ecologia é um ramo da Biologia que se dedica ao estudo das relações que se estabelecem entre plantas e animas, no interior de seu habitat natural ${ }^{111}$.

Baseando-se no mencionado conceito é que se delimitou sua proposta de teorização criminológica. Propôs fosse realizada uma investigação da criminalidade por meio da identificação das áreas espaciais em que se dividiam os grandes conglomerados urbanos e de seus caracteres estruturais.

Assim, essa relação entre os seres e sua zona de habitação, existente na Biologia, estabelece-se também na Criminologia, no que concerne à gênese da conduta criminal.

O estudo elaborado pela Escola de Chicago apresenta ainda estreita ligação com o cenário social norte-americano da década de 1920.

O crescimento industrial acelerado incentivou impulsos migratórios advindos de diversos cantões do globo, o que gerou o aumento acelerado e desorganizado das grandes cidades. Inflaram-se as metrópoles, de forma muito rápida e desordenadamente, obrigandose a convivência forçada entre pessoas sem qualquer identidade de costumes e afinidades. Em menos de um século, Chicago, que era uma pequena cidade de duzentos mil habitantes, transformou-se numa grande metrópole industrial, habitada por três milhões e trezentas mil $\operatorname{pessoas}^{112}$.

Diante dessas mudanças, ocupou-se a teoria do problema da integração de povos tão diversos num mesmo e reduzido espaço urbano e das consequências dessa formação populacional citadina $^{113}$.

O pressuposto da ecologia criminal é o de que a delinquência apresenta taxas mais elevadas onde se identifica uma maior desorganização social, considerada pelos teóricos da Escola como uma patologia social.

Movida pela crença numa sociedade de consenso, identificava a diversidade sóciocultural de determinada área geográfica da cidade como geradora da mencionada desorganização. Acreditava que a intensa mobilidade social existente nessas regiões enfraquecia a relação do indivíduo com sua família, berço de sua socialização primária, bem como com terceiros, diminuindo a coesão entre eles e consequentemente o controle

111 VOLD, George B.; BERNARD, Thomas J. Theoretical Criminology. 3. ed. Nova Iorque: Oxford University Press, 1986.

${ }^{112}$ SHAW, Clifford R; MCKAY, Henry D. Juvenile Deliquency and urban areas. Chicago: University of Chicago, 1942.

${ }^{113}$ A identificação do rápido crescimento das cidades com a geração da criminalidade é ideia que esta Escola toma emprestado das teorizações de Durkheim, como se poderá constatar no item 1.3.1.3. 
social informal ${ }^{114}$, óbice à produção da criminalidade. Emergia daí um conjunto de valores que se afastava do ideal da sociedade normal e desencadeava a conduta delinquente ${ }^{115}$.

A desorganização social era, pois, a justificativa para o aumento das estatísticas da violência.

Daí se deflui a eleição da cidade, mormente os grandes complexos urbanos, como objeto de estudo desta proposta.

Sua geografia foi dividida pela teoria da ecologia criminal em cinco círculos concêntricos, cada qual representando uma zona de povoamento com características próprias, especialmente no tocante às suas taxas e manifestações de criminalidade. Acreditava-se ainda que o crescimento da cidade obedecia a essas divisões, ocorrendo do centro para os extremos da circunferência.

A primeira zona, correspondente a parte central do círculo, denomina-se loop e concentra os distritos comercial e industrial da cidade. É a área de localização, por exemplo, de armazéns, bancos e da administração da cidade.

A zona dois é uma área de transição que concentra as parcelas comercial e industrial, fundidas com as residências das populações pobres, das famílias desestruturadas e dos imigrantes, tais como pensões e bordéis. Trata-se de uma região deteriorada e economicamente desprivilegiada da cidade, construída logo no início de sua expansão, representando, pois, seu território mais antigo.

Nesse território, a presença de distritos comerciais e industriais afeta as áreas residenciais adjacentes, devido, por exemplo, à poluição despejada pelas fábricas e aos sons por elas emitidos, tornando-as um local menos agradável para se habitar. Por tudo isso é que assim que seus moradores obtêm mais recursos financeiros, eles abandonam a área e partem em busca de locais onde lhes sejam possibilitadas melhores condições de vida ${ }^{116}$.

A zona três contém as casas dos trabalhadores e dos imigrantes de segunda geração, com condições econômico-financeiras razoáveis, que lhes permitiram deixar a área de degradação anterior.

\footnotetext{
${ }^{114}$ Trata-se de um controle realizado pelas instituições da sociedade civil tais como a família, a escola e os habitantes do bairro, no intuito de zelar pela observância das normas sociais, ainda que através de sanções. Pode ser realizado em dualidade com o controle social formal, outro extremo do poder de controle, exercido por órgãos públicos encarregados da repressão da criminalidade tais como a Polícia, o Ministério Público e o Poder Judiciário. Sobre este se sobressai por ser mais efetivo e menos seletivo e estigmatizante.

${ }^{115}$ TAYLOR, Ian; WALTON, Paul; YOUNG, Jack. La Nueva Criminología: contribución a una teoria social de la conducta desviada. Tradução de Adolfo Crosa. Buenos Aires: Amorrortu, 1997.

${ }^{116}$ SHAW, Clifford R; MCKAY, Henry D. Juvenile Deliquency and urban areas. Chicago: University of Chicago, 1942.
} 
A zona quatro é composta por casas e apartamentos mais caros, nos quais residem familiares em um número reduzido.

Por fim, tem-se a zona cinco, a mais rica da cidade, onde habitam os que podem viajar todos os dias de casa para o trabalho.

A relação que se estabelece entre as citadas áreas e a criminalidade é a de que quanto mais perto do centro do círculo maiores os índices de ilícitos cometidos, conformando-se aí as áreas de delinquência. Na zona de transição, onde é patente a desorganização social gerada pela heterogeneidade, ociosidade de parte da população, degradação da sua área física, industrialização, urbanismo, entre outros fatores, é que se verificam as taxas mais elevadas de prática criminal, alcoolismo, prostituição e drogadição. Não é, pois, a raça, a cor ou a nacionalidade, mas antes a própria área citadina que aparece relacionada com o crime e com a delinquência. Ademais, evidencia-se também o tema das condições de habitação em geral e da superlotação, em particular, como fatores criminógenos $^{117}$.

A Escola ocupa-se ainda do estudo das manifestações criminosas juvenis ${ }^{118}$.

Shaw e Mckay fizeram um cuidadoso estudo acerca da localização das residências dos adolescentes em conflito com a lei, visando a descobrir de que parte da cidade eles provinham. A proposta da pesquisa foi utilizar como grupo de amostragem os delinquentes da cidade de Chicago processados pela Corte Juvenil, os processados e remetidos as escolas correcionais e, por fim, os que apenas passaram pelo controle da polícia, durante três períodos distintos de tempo, entre os anos de 1900 e 1930, em cada um dos itens perquiridos.

As conclusões alcançadas foram bastante semelhantes nos três focos da pesquisa. No tocante à interferência da justiça juvenil, constatou-se que os jovens moradores das áreas centrais da cidade, um quarto do total, foram os processados pela metade de todas as infrações aferidas no período. Em relação aos jovens enviados aos centros de correção, entre os habitantes da citada região, identificava-se mais da metade das infrações realizadas em toda a cidade, chegando eles a alcançarem, entre os anos de 1927 e 1933, uma taxa de criminalidade $88 \%$ maior do que a dos residentes nas zonas mais extremas de Chicago. Os apreendidos pela polícia, que habitavam as áreas centrais, cometeram $49 \%$ das infrações totais.

\footnotetext{
${ }^{117}$ MANNHEIM, Hermann. Criminologia Comparada. Lisboa: Calouste Gulbenkian, 1984. v. 2.

${ }^{118}$ Destacaram-se nessa área os estudos de Clifford Shaw e Henry Mckay, os quais escreveram, em coautoria, os livros Social factors in juvenile delinquency (1931) e Juvenile deliquency and urban areas (1942).
} 
Desta feita, evidenciou-se a vinculação entre a área de moradia do adolescente e sua opção pela criminalidade. Corroborou com ela a constatação de que, durante o interregno de trinta anos em que se realizaram os estudos, as taxas de delinquência haviam se mantido constantes.

Concluíram, então, que também em relação à delinquência juvenil suas causas são inerentes na comunidade, não variando de acordo com a nacionalidade ou características específicas da população ${ }^{119}$.

Portanto, baseada nas mesmas proposições da ecologia criminal, identificou a existência de maiores taxas de criminalidade juvenil nas áreas citadinas onde a desorganização e desestruturação social estavam mais presentes.

Por isto, aceitando-se a criminalidade também dessa parcela da população como produto da desorganização social, não se acreditava na efetividade do tratamento individual do infrator. O problema só seria resolvido, pregava-se, por meio de mudanças nas condições de vida nas áreas de delinquência.

Resta evidente que os autores da Escola de Chicago não apontam diferenças ontológicas entre os seres delinquentes e os não delinquentes, caráter que representou um avanço em relação às teorias de cunho biológico. Para eles, a diferença entre ambas as categorias é fundamentalmente a área geográfica onde residem.

Consideram, então, que "a cidade 'produz' delinquência",

Outra grande diferença que se destaca ao cotejá-la com a Criminologia antropológica é a busca das causas do comportamento coletivo, não mais individual.

No entanto, este afastamento não foi total. Conforme explanado, os ecologistas criminais se utilizaram de categorias das ciências naturais, especialmente da biologia, para justificar os problemas sociais, tal qual durante a hegemonia positivista, quando a análise criminológica estava estreitamente vinculada ao método das ciências naturais ${ }^{121}$.

Esse fato se evidencia na utilização das expressões função, meio ambiente, organismo, entre outras, comuns à nova proposta.

\footnotetext{
${ }^{119}$ SHAW, Clifford R.; MCKAY, Henry D. Juvenile Deliquency and urban areas. Chicago: University of Chicago, 1942.

${ }^{120}$ GARCÍA-PABLOS DE MOLINA, Antonio. Criminologia: uma introdução a seus fundamentos teóricos. Tradução de Luiz Flávio Gomes. São Paulo: Revista dos Tribunais, 1992. p. 200.

${ }^{121}$ ANITUA, Gabriel Ignacio. Histórias dos pensamentos criminológicos. Tradução de Sérgio Lamarão. Rio de Janeiro: Revan, 2008.
} 
De qualquer modo, iniciou-se com a Escola de Chicago uma sociologia mais rigorosa e empírica, visando ao conhecimento da realidade social e, mais especificamente, da realidade urbana ${ }^{122}$. Para tanto elevou a importância dos estudos de campo e biográficoindividuais, dedicou atenção às investigações qualitativas, bem como às estatísticas criminais, influenciada que foi pela Escola Cartográfica.

Portanto, o empirismo, a assunção de uma finalidade pragmática e a orientação a uma finalidade prática são algumas das características metodológicas principais da Escola $^{123}$.

A partir da ecologia criminal o fator espacial torna-se importante não apenas para explicar o delito, mas também se transforma em peça fundamental nas propostas para preveni-lo, nas quais se inserem novas políticas arquitetônicas e urbanísticas ${ }^{124}$. Entre elas, efetivadas basicamente nas áreas mais socialmente desorganizadas da cidade, destacam-se a melhoria das condições econômicas e sociais, como forma de possibilitar mais oportunidades às pessoas; a organização de ações comunitárias, envolvendo os habitantes do bairro, visando a reforçar o controle social informal estremecido; o oferecimento de emprego aos indivíduos economicamente ativos, evitando, assim, o ócio; a restauração das fachadas das residências e prédios públicos ${ }^{125}$.

Embora tenha inaugurado uma nova maneira de se perquirir sobre a etiologia do crime, a ecologia criminal não obteve apenas êxitos.

Trata-se de uma teoria conservadora, uma vez que, em vez de buscar descobrir o processo por meio do qual as áreas de delinquência se desenvolvem, atém-se apenas às características dessas regiões, atribuindo a elas uma ação causal da criminalidade. Por isso também não foi capaz de explicar a criminalidade produzida fora das áreas de delinquência.

Ao limitar sua investigação às áreas de residência dos delinquentes, obliterou o fato de que este não é necessariamente o local onde eles praticavam seus ilícitos.

Constatou-se ainda que suas explicações, por vezes, contradiziam suas observações. Pregavam que a desordem social era a causa das manifestações delinquentes, mas, na

${ }^{122}$ GARRIDO, Vicente; STANGELAND, Per; REDONDO, Santiago. Principios de Criminología. 2. ed. Valência: Tirant lo blanch, 2001.

${ }^{123}$ GARCÍA-PABLOS DE MOLINA, Antonio. Criminologia: uma introdução a seus fundamentos teóricos. Tradução de Luiz Flávio Gomes. São Paulo: Revista dos Tribunais, 1992.

${ }^{124}$ GARCÍA-PABLOS DE MOLINA, Antonio. Criminologia: uma introdução a seus fundamentos teóricos. Tradução de Luiz Flávio Gomes. São Paulo: Revista dos Tribunais, 1992.

${ }^{125}$ SHAW, Clifford R; MCKAY, Henry D. Juvenile Deliquency and urban areas. Chicago: University of Chicago, 1942. 
realidade, as análises empíricas realizadas apontavam para a existência não de uma desordem, mas sim de organizações sociais diversas, ainda que minoritárias, coexistindo num mesmo ambiente geográfico, e com valores distintos ${ }^{126}$.

Tem-se também que as soluções propostas para diminuir as taxas de delinquência não se comprovaram, efetivamente.

Desta feita, em vista da percepção de suas falhas, após ter suscitado, em meados do século XIX, grande entusiasmo e ter atingido seu apogeu no período entre as duas guerras mundiais, a teoria da ecologia criminal iniciou seu declínio progressivo posteriormente ao ano de 1945. De qualquer forma, já se erigia outra teoria criminológica, que será em seguida analisada, a qual não se olvidou de suas lições.

\subsubsection{Teoria da Associação Diferencial}

A teoria da associação diferencial foi enunciada por primeiro na $3^{\mathrm{a}}$ edição da obra Principles of Criminology, escrita por Edwin Sutherland, no ano de 1939.

O citado autor foi bastante influenciado em suas ideias por Gabriel Tarde e sua formulação das leis da imitação, segundo as quais o cometimento do delito é um conhecimento aprendido por meio do contato com sujeitos que o praticam ${ }^{127}$. Tal influência ficou evidente em sua tese sobre o aprendizado das condutas criminais.

Sutherland formula sete proposições explicativas de sua teoria etiológicocriminológica do comportamento criminoso, as quais permitem que seu pensamento seja compreendido com clareza de sentido ${ }^{128}$.

Em primeiro, defende que os processos que culminam no comportamento criminoso sistemático, são fundamentalmente os mesmos, na forma, dos que resultam no comportamento legal. Nota-se, então, que "o comportamento criminoso difere do comportamento legal nos padrões pelo qual é julgado, mas não nos princípios dos

${ }^{126}$ GARRIDO, Vicente; STANGElAND, Per; REDONDO, Santiago. Principios de Criminología. 2. ed. Valência: Tirant lo blanch, 2001.

${ }^{127}$ Tarde elaborou três principais leis de imitação, as quais forneciam uma explicação lógica dos moldes em que esta se realizava. Concluiu, então, que a imitação está proporcionalmente relacionada com o grau de contato entre os sujeitos, uma vez que se imitam, precipuamente, as pessoas mais próximas; que os indivíduos inferiores imitam os superiores; e que as novas modas comportamentais substituem as velhas.

${ }^{128}$ SUTHERLAND, Edwin H. Princípios de Criminologia. Tradução de Asdrúbal Mendes Gonçalves. São Paulo: Livraria Martins, 1949. 
processos genéticos"129.

Em segundo, nos mesmos moldes do que ocorre com o comportamento legal, cuja associação para sua prática se dá entre os respeitadores das normas, o criminoso é determinado num processo de associação com os que cometem crimes.

Em terceiro, a causa do comportamento criminoso é a associação diferencial. Os princípios dessa associação coincidem com os das associações lícitas, diferindo apenas em seu conteúdo, razão pela qual a associação criminosa é denominada diferencial.

Em quarto, a probabilidade de adoção do comportamento criminoso é determinada pela frequência e consistência dos contatos do indivíduo com padrões de comportamento da mesma natureza. Nesse sentido, a proporção entre os atos legais e ilegais praticados por uma pessoa é igual à proporção dos contatos com os comportamentos criminoso e legal de outros que estabelece.

Em quinto, as diferenças entre as pessoas, no tocante às suas características pessoais ou sociais, causam o crime somente quando afetam a associação diferencial ou a frequência e consistência dos contatos com padrões criminosos. Para a compreensão desse pressuposto, mister se recorra a um exemplo fornecido por Sutherland, no qual o autor se utiliza de uma narrativa sobre uma família que é obrigada a mudar-se para uma área marginalizada da cidade, onde as taxas delinquencias são bastante elevadas.

O fato de a família exigir que seu filho retorne imediatamente da escola para casa, sem estabelecer nenhum contato com estranhos, impedirá que se concretize a associação diferencial. O mesmo se daria no caso de uma criança tímida, que por conta dessa sua característica pessoal não estabelecesse contatos com os moradores (criminosos) do bairro. Em contrapartida, se o infante não é bem quisto em seu próprio lar e é obrigado a passar o dia inteiro na rua, certamente estas associações indesejadas serão estabelecidas.

Em sexto, a causa fundamental do estabelecimento de associações diferenciais é o conflito cultural. A associação só pode ser diferencial, tendo em vista a existência de grupos culturais discrepantes numa dada sociedade.

Em sétimo, a desorganização social ${ }^{130}$ é a causa básica do comportamento criminoso.

${ }^{129}$ SUTHERLAND, Edwin H. Princípios de Criminologia. Tradução de Asdrúbal Mendes Gonçalves. São Paulo: Livraria Martins, 1949. p. 12.

${ }^{130}$ Em revisão de sua obra, Sutherland propõe a substituição do termo desorganização social, utilizado primeiramente pela Escola de Chicago, pelo de organização social diferencial, o que evidencia sua concepção da sociedade como uma pluralidade normativa. 
Para o autor, há duas facetas importantes desse conceito. Numa delas, a citada desorganização tem como aspecto específico o conflito cultural. Há a desorganização porque há o conflito entre culturas diversas nas sociedades modernas. Noutra, a inércia dos que pautam suas vidas no exercício de condutas legais, frente aos atos ilícitos, também pode estimular a ocorrência de crimes, dada a desorganização social gerada por tal inação. Em sentido oposto, quando a comunidade se insurge contra determinada conduta ilegal passa a ser possível extirpá-la ou diminuir radicalmente sua ocorrência ${ }^{131}$.

A ideia central da teoria, pois, é a de que o comportamento criminal, bem como o pró-social é aprendido por meio dos mecanismos de interação e comunicação entre os indivíduos. Ademais, prega que a causa da criminalidade é a associação diferencial, isto é, o contato excessivo com pessoas ostentadoras de definições favoráveis à delinquência.

Evidencia-se, então, que a associação diferencial conforma

a primeira teoria sistemática em que o delito é visto como um comportamento normal dentro de uma sociedade, a qual é sua causa direta; não obstante o material que emprega ser sócio-psicológico ${ }^{132}$.

A teoria se compõe de dois elementos basilares, ambos derivados da teoria interacionista simbólica de George Herbert Mead ${ }^{133}$, concernentes ao conteúdo do que é aprendido e ao processo por meio do qual o citado aprendizado se realiza.

No primeiro incluem-se as técnicas específicas daquela ação, suas motivações, racionalizações, atitudes, ou seja, os elementos cognitivos favoráveis à apreensão da conduta ilegal. No tocante ao processo de aprendizagem, revela-se que sua ocorrência tem lugar no seio das interações mais íntimas do indivíduo ${ }^{134}$.

As associações, sejam elas determinantes do comportamento legal ou ilegal, variam em frequência, duração, prioridade e intensidade.

Os contatos duradouros e frequentes, como é obvio, têm maior influência pedagógica do que os fugazes ou ocasionais. Os realizados durante a infância exercem

\footnotetext{
${ }^{131}$ Sutherland cita como ilustrativa dessa situação um fato empiricamente ocorrido, no qual os jogadores de determinado time de basebol receberam uma quantia em dinheiro para que perdessem uma partida. Relata o autor que, ao tornar-se pública tal conduta, ela gerou tanta comoção social que houve uma organização no sentido de reagir contra a prática. Após isso, ao que se sabe, comportamentos dessa natureza não mais voltaram a ocorrer. Cf. SUTHERLAND, Edwin H. Princípios de Criminologia. Tradução de Asdrúbal Mendes Gonçalves. São Paulo: Livraria Martins, 1949.

${ }^{132}$ BERGALLI, Roberto. Perspectiva sociológica: desarollos ulteriores. In: ; BUSTOS RAMÍREZ, Juan; MIRALLES, Teresa. El Pensamiento Criminológico: un análisis crítico. Bogotá: Temis, 1983. v. 1. p. 118.

${ }^{133}$ A teoria do interacionismo simbólico será abordada pormenorizadamente no item 2.2.1, tendo em vista a influência que exerceu também na construção do labelling approach.

134 VOLD, George B.; BERNARD, Thomas J. Theoretical Criminology. 3. ed. Nova Iorque: Oxford University Press, 1986.
} 
influência prioritária em cotejo com os efetivados em etapas posteriores da vida do sujeito. Por fim, o modelo é tanto mais convincente para o indivíduo quanto mais prestígio ele atribuir à pessoa ou grupo cujas definições e exemplos apreende ${ }^{135}$.

É possível perceber, dados os pressupostos mencionados, que essa formulação teórica surge como oposição às ideias de que o crime derivaria de uma patologia individual $^{136}$, tal qual pregava a Antropologia Criminal, bem como de que seria decorrente de uma anomalia social, representada pela desorganização social, tal qual propunha a Escola de Chicago ${ }^{137}$. Contraria ainda as explicações funcionalistas de acordo com as quais o delito resulta da inadaptação social típica dos sujeitos pertencentes aos agrupamentos sociais menos abastados.

$\mathrm{Na}$ formulação de Sutherland o que causa a delinquência são as ideias e não as condições sociais. Ou seja, desencadeiam a manifestação criminal as definições favoráveis à violação da lei penal e não a miséria social em que vive a pessoa ${ }^{138}$.

A descrição do delito enquanto conduta normal, tal qual proposto pela Criminologia da anomia, é um grande mérito da teoria. Não apenas pelas respostas que produziu a partir daí, mas também pelas influências que gerou.

A concepção da normalidade da ação ilegal fez surgir a reflexão sobre o porquê o comportamento aprendido normalmente é considerado criminoso por um grupo e permitido por outro $^{139}$.

De acordo com a presente teorização, a melhor maneira de prevenir a delinquência é por meio do estímulo ao estabelecimento de associações neutras.

${ }^{135}$ GARCÍA-PABLOS DE MOLINA, Antonio. Criminologia: uma introdução a seus fundamentos teóricos. Tradução de Luiz Flávio Gomes. São Paulo: Revista dos Tribunais, 1992.

${ }^{136}$ Para Sutherland "uma pessoa não participa do comportamento criminoso sistemático por herança. Nenhum indivíduo herda tendências que fazem dêle inevitàvelmente criminoso ou respeitador da lei". Cf. SUTHERLAND, Edwin H. Princípios de Criminologia. Tradução de Asdrúbal Mendes Gonçalves. São Paulo: Livraria Martins, 1949. p. 13.

137 Para a teoria da associação diferencial o delito não deriva da falta de ordem social, ou seja, da desorganização social nos termos da defendida pela Escola de Chicago, mas sim da existência de uma determinada organização integrada por grupos distintos, dentre os quais alguns são favoráveis e outros contrários ao cumprimento da norma. Cf. GARRIDO, Vicente; STANGELAND, Per; REDONDO, Santiago. Principios de Criminología. 2. ed. Valência: Tirant lo blanch, 2001.

${ }^{138}$ Em consonância com sua tese de que o crime não é determinado pelas condições sociais desfavoráveis em que vive o sujeito, Sutherland, após o ano de 1939, e até o fim de sua vida, dedicou-se ao estudo dos crimes de colarinho branco. Pode definir-se esta modalidade ilícita como aquela praticada por uma pessoa respeitada e de elevado status sócio-econômico, no âmbito da sua profissão. Sobre o tema ver: SHECAIRA, Sérgio Salomão. Criminologia. 2. ed. rev. São Paulo: Revista dos Tribunais, 2008.

${ }^{139}$ Sutherland tentou responder a esta questão com a teorização do crime do colarinho branco, mas também influenciou outras teorias criminológicas a buscarem essa resposta, tal qual o labelling approach. Cf. VOLD, George B.; BERNARD, Thomas J. Theoretical Criminology. 3. ed. Nova Iorque: Oxford University Press, 1986. 
Existem associações negativas - contrárias ao cumprimento das normas - e positivas - favoráveis a sua obediência. As neutras representam aquelas que valorativamente não estimulam nem a infração nem a observância das leis. São atividades inócuas que reduzem as possibilidades espaço-temporais de participação em atividades delitivas $^{140}$.

Sutherland define sua preferência pela prevenção da criminalidade nos seguintes termos: "a prevenção é a orientação lógica a adotar-se quando se trata do crime. Os castigos e os outros métodos de tratamento são, quando muito, métodos de defesa" ${ }^{\text {"141. }}$.

Acredita que o controle penal por meio das ações das autoridades será tanto mais eficaz quanto mais desenvolvido estiver e observado for o estudo científico das causas criminais.

Embora sem excluir de antemão nenhuma forma de controle, crê que o método principal para sua efetivação é certamente o educacional, sendo provável que a dor e o sofrimento não precisem representar um papel importante na repressão da criminalidade.

No que concerne à prisão, Sutherland assevera a existência de males nesse tipo de punição, mas defende que ela não pode ser abolida, já que a atitude punitivista ainda é muito forte entre os membros do corpo social e as reprimendas que poderiam porventura substituí-la ainda não foram devidamente desenvolvidas.

De qualquer forma, tal qual defende para as outras espécies de sanção, crê que não se pode abandonar, no interior do cárcere, o trabalho educacional e de reforma ${ }^{142}$.

Revela ainda que

o êxito da prisão em demover do crime o público é provàvelmente muito menor que o seu êxito na incapacitação dos criminosos... O êxito da prisão como meio de regeneração é muito pequeno embora também seja difícil determiná-lo acuradamente ${ }^{143}$.

A despeito de sua importância para o aprimoramento das explicações criminológicas do fenômeno ilícito, destacando a influência dos processos de comunicação em sua gênese, a teoria da associação não ficou imune a críticas.

\footnotetext{
${ }^{140}$ GARRIDO, Vicente; STANGELAND, Per; REDONDO, Santiago. Principios de Criminología. 2. ed. Valência: Tirant lo blanch, 2001. Podem ser citados como exemplos de associações para a realização de atividades neutras os grupos desportivos, de pintura ou de artesanato.

${ }^{141}$ SUTHERLAND, Edwin H. Princípios de Criminologia. Tradução de Asdrúbal Mendes Gonçalves. São Paulo: Livraria Martins, 1949. p. 692.

${ }^{142}$ SUTHERLAND, Edwin H. Princípios de Criminologia. Tradução de Asdrúbal Mendes Gonçalves. São Paulo: Livraria Martins, 1949.

${ }^{143}$ SUTHERLAND, Edwin H. Princípios de Criminologia. Tradução de Asdrúbal Mendes Gonçalves. São Paulo: Livraria Martins, 1949. p. 490. Evidencia-se no excerto do autor críticas a finalidade preventiva geral negativa e a real eficácia da função preventiva especial positiva da pena privativa de liberdade.
} 
Desenvolveu ela uma explicação macrossocial para o crime e, nesse sentido, acabou por desconsiderar as características individuais do sujeito e seu processo único de aprendizagem criminal.

Simplificou o mencionado processo e o construiu de forma mecanicista ao desconsiderar a diferença nas aptidões para aprender.

$\mathrm{Na}$ realidade, Sutherland nem sequer se preocupou em fornecer explicações à criminalidade individual, tendo inclusive contestado tal possibilidade, ao postular que

a delinqüência é acidental quando considerada como ato específico de uma pessoa específica. Ninguém pode explicar porque uma moeda dá anverso num lance particular. Atribui-se isso ao acaso. $\mathrm{O}$ acaso não significa que não haja causas operando, mas sim que as causas são tão complicadas que não podem analisar-se $^{144}$.

Tendo em vista o pressuposto da criminalidade como comportamento aprendido, não se explica sua origem antes desse marco, nem como alguém que nunca teve contato com comportamentos desviantes, em dado momento, opta por praticá-los.

Falha foi ainda a conceituação da desorganização social, olvidando-se de que em qualquer estrutura social haverá contradições, desigualdades e conflitos, os quais darão oportunidade ao surgimento de novas condutas delitivas, visto que nenhuma organização social é permanente ${ }^{145}$.

Um grande erro da teoria consiste na sua pretensão de ser monofatorial, isto é, conter todas as explicações para fenômeno criminal. Dada sua complexidade, não é difícil perceber que está fadada a falência qualquer formulação que tente individualizar as causas do crime ${ }^{146}$.

Em seu lugar, assim, ganharam força as teorizações criminológicas orientadas pela ideia de classe, tais como a anomia e as subculturas delinquentes.

${ }^{144}$ SUTHERLAND, Edwin H. Princípios de Criminologia. Tradução de Asdrúbal Mendes Gonçalves. São Paulo: Livraria Martins, 1949. p. 11.

${ }^{145}$ COSTA, Álvaro Mayrink da. Criminologia. 3. ed. Rio de Janeiro: Forense, 1982.

${ }^{146}$ DIAS, Jorge de Figueiredo; ANDRADE, Manuel da Costa. Criminologia: o homem delinqüente e a sociedade criminógena. 2 reimp. Coimbra: Coimbra Editora, 1997. 


\subsubsection{Teoria da Anomia}

A teoria da anomia destaca-se por pregar a normalidade e a funcionalidade da conduta delinquente ${ }^{147}$.

Nesse sentido, considera que ela não está atrelada a nenhuma patologia social ou individual, mas sim ao regular funcionamento da ordem social, das suas estruturas e dos fenômenos cotidianos no seio de uma organização intacta ${ }^{148}$. Assim, questiona o princípio do bem e do mal, postulado da Escola Positivista, segundo o qual a conduta criminosa e o próprio criminoso caracterizavam a representação do mal ${ }^{149}$.

Evidencia-se o objetivo de desvendar quais as tensões socialmente estruturadas que induzem a procura por soluções desviantes. Indaga-se, desta feita, como o sistema social produz o crime ${ }^{150}$.

Desloca-se, pois, o foco da atenção criminológica para o sistema social.

Como expressão mais acabada do modelo funcionalista, a teoria da anomia caracteriza-se por sua natureza estrutural, seu determinismo sociológico, pela aceitação do caráter normal e funcional do crime, bem como pela adesão à ideia de consenso sobre os valores que presidem a ordem social.

O funcionalismo busca criar um sistema próprio para as ciências sociais, negando a viabilidade de um mero transplante de categorias das ciências naturais e pretendendo superar a visão fatorial e de dados isolados, sedimentados pelo Positivismo ${ }^{151}$.

Desse modo,

o conceito de função não só permite perceber a sociedade como um processo, senão, ademais, afastar-se de uma transposição mecânica da bagagem científica das ciências naturais às ciências sociais; por outro lado, o conceito de função leva implícito que não se trata da análise do fato isolado, senão da consideração

\footnotetext{
${ }^{147}$ Esta concepção do fenômeno criminal representa, mais numa perspectiva lógica do que cronológica, o ponto de chegada da evolução da racionalidade própria das teorias etiológica-explicativas do crime. Cf. DIAS, Jorge de Figueiredo; ANDRADE, Manuel da Costa. Criminologia: o homem delinqüente e a sociedade criminógena. 2 reimp. Coimbra: Coimbra Editora, 1997.

${ }^{148}$ GARCÍA-PABLOS DE MOLINA, Antonio. Criminologia: uma introdução a seus fundamentos teóricos. Tradução de Luiz Flávio Gomes. São Paulo: Revista dos Tribunais, 1992.

${ }^{149}$ BARATTA, Alessandro. Criminologia e Dogmática Penal. Passado e futuro do modelo integral da Ciência Penal. Revista de Direito Penal, Rio de Janeiro, n. 31, p. 5-37, jan.Ijun. 1981.

${ }^{150}$ DIAS, Jorge de Figueiredo; ANDRADE, Manuel da Costa. Criminologia: o homem delinqüente e a sociedade criminógena. 2 reimp. Coimbra: Coimbra Editora, 1997.

${ }^{151}$ BUSTOS RAMÍREZ, Juan. Criminología y evolución de las ideas sociales. In: BERGALLI, Roberto; ; MIRALlES, Teresa. El Pensamiento Criminológico: un análisis crítico. Bogotá: Temis, 1983. v. 1.
} 
do sistema, isto é, da relação com o contexto geral em que se dão as diversas manifestações ${ }^{152}$.

Evidencia-se, então, o estabelecimento de uma vinculação entre o delito, as estruturas sociais e os fenômenos da vida cotidiana.

O conceito de anomia, que empresta nome à presente teoria, foi desenvolvido por Durkheim $^{153}$ e mais tarde redefinido por Robert Merton, de forma mais concreta, vez que aplicado à realidade da sociedade norte-americana ${ }^{154}$.

Em termos gerais, para Durkheim, a lei serve, nas sociedades modernas, para regulamentar as ações dos diferentes grupos que dela fazem parte. Quando essa regulação é inadequada ou incipiente, forma-se uma situação de anomia.

Ela representa a crise, a perda de legitimidade ou o desmoronamento das normas e valores presentes no corpo social, em decorrência das radicais transformações que inauguram as sociedades modernas ${ }^{155}$.

Já para Merton, verifica-se nas sociedades contemporâneas uma mudança muito rápida dos valores sociais vigentes e não há tempo para que se sedimente sua substituição por outros alternativos. Neste interregno, o indivíduo fica sem referência das regras a obedecer, constituindo-se uma situação anômica.

A despeito das diferenças existentes entre ambos os conceitos, as quais serão ressaltadas no decorrer deste item, verifica-se, nas duas concepções, a identificação da anomia como uma formulação sociológica, propriedade de um sistema social e não de grupos individualmente considerados ${ }^{156}$.

O caldo cultural do final do século XIX na França e início do XX, período em que viveu Durkheim, foi determinado por eventos históricos marcantes, influenciadores de toda

${ }^{152}$ BUSTOS RAMÍREZ, Juan. Criminología y evolución de las ideas sociales. In: BERGALLI, Roberto; ; MIRALlES, Teresa. El Pensamiento Criminológico: un análisis crítico. Bogotá: Temis, 1983. v. 1. p. $37-38$.

${ }^{153} \mathrm{O}$ conceito de anomia foi desenvolvido por Durkheim, de forma mais explícita, em suas obras $A$ divisão do trabalho social e $O$ suicídio, publicadas, respectivamente, nos anos de 1893 e 1897.

${ }^{154}$ Note-se que a teoria da anomia, desenvolvida inicialmente na Europa, também influenciou as elaborações científicas da Sociologia Criminal norte-americana. Primeiro porque foi reelaborada por Robert Merton, que a adequou ao contexto socioeconômico dos Estados Unidos, e depois pelo fato de suas ideias terem contribuído com as formulações da subcultura delinquente, transmissão cultural, associação diferencial, ecologia e com o interacionismo, todas representantes da ciência criminológica norte-americana. Sobre o assunto ver: VOLD, George B.; BERNARD, Thomas J. Theoretical Criminology. 3. ed. Nova Iorque: Oxford University Press, 1986 e DIAS, Jorge de Figueiredo; ANDRADE, Manuel da Costa. Criminologia: o homem delinqüente e a sociedade criminógena. 2 reimp. Coimbra: Coimbra Editora, 1997.

${ }^{155}$ GARCÍA-PABLOS DE MOLINA, Antonio. Criminologia: uma introdução a seus fundamentos teóricos. Tradução de Luiz Flávio Gomes. São Paulo: Revista dos Tribunais, 1992.

${ }^{156}$ Além de Durkheim e Merton, outros teóricos também desenvolveram o estudo da anomia. Dentre eles destacam-se Talcott Parsons e Cloward e Ohlin. 
sua concepção criminologista sociológica. São a vivência das consequências da Revolução Francesa, ocorrida no ano de 1789, e da rápida industrialização do país que o fizeram centrar sua atenção no papel das forças sociais sobre a determinação das condutas humanas.

Atribuiu às crises sociais, pela perturbação da ordem e consequente anomia que provocam, a causa única do crescimento do suicídio ${ }^{157}$, conclusão que estende ao crime.

E a razão, segundo ele, do abrupto aumento nas taxas de criminalidade e suicídios no período anômico é o enfraquecimento da consciência coletiva daí decorrente ${ }^{158}$.

Isso porque o que impede a impulsão de um sujeito à prática criminosa não é nenhuma norma jurídica, mas sim essa consciência superior a sua, cuja imperiosidade o indivíduo simplesmente sente. A incapacidade das pessoas de realizar essa ação durante a crise, enfraquecendo-se, assim, sua consciência coletiva, se externaliza por meio da conduta social que adotam ${ }^{159}$.

Não há aqui nenhuma contradição com a normalidade do crime defendido pela teoria. O que é considerado funcional é a existência de índices constantes de criminalidade e não de seu repentino incremento, tal qual ocorre nas situações de anomia social ${ }^{160}$.

A normalidade do delito coincide com sua generalidade. Identifica-se a conduta normal com a geral, isto é, com aquela praticada frequente e repetidamente numa dada sociedade. Em contrapartida, patológico deveria ser considerado apenas o comportamento não usual.

Nas palavras do idealizador da ideia:

$$
\begin{aligned}
& \text { classificar o crime entre os fenômenos de sociologia normal não é apenas dizer } \\
& \text { que constitui fenômeno inevitável, embora lastimável e devido à maldade } \\
& \text { incorrigível dos homens; é afirmar que é um fator da saúde pública, uma parte } \\
& \text { integrante de toda sociedade sã }{ }^{161} \text {. }
\end{aligned}
$$

\footnotetext{
${ }^{157}$ DURKHEIM, Émile. El suicidio. Tradução de Mariano Ruiz-Funes. Madri: Editorial Reus, 1928.

${ }^{158}$ Consiste a consciência coletiva numa uniformidade de crenças presente em graus diversos, em qualquer organização social.

${ }^{159}$ DURKHEIM, Émile. El suicidio. Tradução de Mariano Ruiz-Funes. Madri: Editorial Reus, 1928.

${ }^{160}$ DURKHEIM, Émile, As regras do método sociológico. Tradução de Maria Isaura Pereira de Queiroz. 9. ed. São Paulo: Editora Nacional, 1978.

${ }^{161}$ DURKHEIM, Émile, As regras do método sociológico. Tradução de Maria Isaura Pereira de Queiroz. 9. ed. São Paulo: Editora Nacional, 1978. p. 58.
} 
Outra faceta da normalidade do crime se identifica com sua colaboração no desenvolvimento das sociedades. Se a consciência coletiva fosse tão rígida a ponto de nem sequer ser violada e não se erigir oposição a ela, não haveria possibilidade de $\operatorname{progresso~}^{162}$.

Assim, na visão funcionalista, o "crime é o preço que a sociedade paga pela possibilidade de progresso"163.

Durkheim identifica dois tipos distintos de solidariedades, as quais divergiriam de acordo com o modelo de sociedade considerada, se mecânica ou orgânica.

A solidariedade mecânica é considerada típica das sociedades primitivas, nas quais a diferenciação entre os seus membros era praticamente inexistente, compartilhando todos de valores, trabalho e circunstâncias de vida bastante semelhantes. A solidariedade aqui se assenta na ameaça representada por um direito repressivo, baseado numa autoridade moral, bem como na uniformidade dos indivíduos que compõe esta espécie de organização social $^{164}$.

Por sua vez, a solidariedade orgânica é característica dos grupos sociais mais desenvolvidos, ou seja, das sociedades contemporâneas, em que se identifica já uma organizada divisão do trabalho, sendo cada segmento social mais dependente do outro, dada a especificidade dos saberes ${ }^{165}$. Assim, a solidariedade aqui é baseada na diversidade de funções de cada parte da sociedade e na existência de um direito de caráter meramente restitutivo $^{166}$.

Durkheim crê numa tendência certa de evolução e consequente transformação de todas as sociedades, percorrendo o caminho que as guiaria no sentido do desenvolvimento. Implicaria esta transação o aumento da tolerância em relação às diversidades, a punição cada vez menos rigorosa das faltas, a expansão de leis funcionais para regulamentar toda a

\footnotetext{
${ }^{162}$ Exemplo disso foi a criminalização dos líderes dos movimentos de união dos anos vinte e trinta, bem como dos mentores dos movimentos civis dos anos sessenta. Se estes não houvessem transgredido as regras, não teríamos vivido as evoluções causadas por estes rompimentos. Cf. VOLD, George B.; BERNARD, Thomas J. Theoretical Criminology. 3. ed. Nova Iorque: Oxford University Press, 1986.

163 VOLD, George B.; BERNARD, Thomas J. Theoretical Criminology. 3. ed. Nova Iorque: Oxford University Press, 1986, p. 149.

${ }^{164}$ DURKHEIM, Émile. La división del trabajo social. Tradução de Carlos G. Posada. Madri: Daniel Jorro, 1928.

${ }^{165}$ A grande relevância da divisão do trabalho nas sociedades modernas circunscreve-se ao efeito moral que produz, qual seja, a criação de um sentimento de solidariedade entre os membros do corpo social. A citada divisão representa, portanto, a principal, senão a única, fonte de solidariedade social. Seria, em outros termos, sua condição de existência. Cf. DURKHEIM, Émile. La división del trabajo social. Tradução de Carlos G. Posada. Madri: Daniel Jorro, 1928.

${ }^{166}$ DURKHEIM, Émile. La división del trabajo social. Tradução de Carlos G. Posada. Madri: Daniel Jorro, 1928.
} 
nova gama de comportamentos que surgiam e o aumento das taxas de criminalidade, provocadas por rápidas mudanças sociais.

E por acreditar que o castigo enfraquecia-se, tornando-se menos severo, na medida em que as sociedades evoluíam, iludia-se ao considerar a pena privativa de liberdade como um exemplo da moderna benevolência punitiva ${ }^{167}$.

$\mathrm{Na}$ formulação de Durkheim, a pena era necessária porque o crime fere a consciência coletiva.

Opondo-se a visão surgida com o Iluminismo de que a sanção estatal serviria como instrumento de defesa da sociedade, Durkheim a sustenta em fundamentos de moralidade coletiva. Ela é a resposta passional ao atentado contra a consciência coletiva.

Assim, não deixava de representar uma vingança, um ato de violência contra a violência praticada pelo criminoso, tanto no seio das sociedades primitivas como das contemporâneas $^{168}$.

No entanto, a despeito de estar repousada neste ímpeto de vingança, acreditava-se que a pena alcançava um efeito funcional de reafirmação dos valores sociais e reforço à adesão aos mesmos ${ }^{169}$.

Afirmava, pois, a concordância da sociedade com suas regras vigentes e elevava seus cumpridores, na medida em que inferiorizava os delinquentes ${ }^{170}$.

Merton, como já aventado, empresta uma concepção mais moderna à teoria da anomia. Busca desvendar o modo pelo qual algumas estruturas sociais pressionam certas pessoas a adotarem uma conduta não conformista ${ }^{171}$.

Para ele, nas sociedades modernas, a cultura preponderante aponta os objetivos que devem ser almejados pelos seus integrantes e os meios de alcançá-los ${ }^{172}$. Ocorre que o que

\footnotetext{
${ }^{167}$ ANITUA, Gabriel Ignacio. Histórias dos pensamentos criminológicos. Tradução de Sérgio Lamarão. Rio de Janeiro: Revan, 2008.

${ }^{168}$ ANITUA, Gabriel Ignacio. Histórias dos pensamentos criminológicos. Tradução de Sérgio Lamarão. Rio de Janeiro: Revan, 2008.

${ }^{169}$ ANITUA, Gabriel Ignacio. Histórias dos pensamentos criminológicos. Tradução de Sérgio Lamarão. Rio de Janeiro: Revan, 2008. Evidencia-se, neste ponto, uma finalidade preventiva geral positiva da pena. Cf. DIAS, Jorge de Figueiredo; ANDRADE, Manuel da Costa. Criminologia: o homem delinqüente e a sociedade criminógena. 2 reimp. Coimbra: Coimbra Editora, 1997.

${ }^{170}$ Essa significação estrutural-funcionalista de controle social é o marco intelectual e o projeto ideológico a partir do qual o termo se expande. Cf. BERGALLI, Roberto. Controle social: suas origens conceituais e usos instrumentais. Revista Brasileira de Ciências Criminais, São Paulo, ano 1, n. 3, p. 31-38, jul.Iset. 1993.

${ }^{171}$ MERTON, Robert K. Sociologia: teoria e estrutura. São Paulo: Mestre Jou, 1970.

${ }^{172}$ Richard Cloward e Lloyd Ohlin foram dois importantes continuadores da obra de Merton. No entanto, não se limitaram aos conceitos por ele propostos e trataram de unir, numa única formulação teórica, os conceitos de anomia e associação diferencial, numa tese de matiz subcultural. Sobre o assunto ver: TAYLOR, Ian; WALTON, Paul; YOUNG, Jack. La Nueva Criminología: contribución a una teoria social de la conducta
} 
se verifica, é uma ênfase maior aos fins do bem estar e sucesso econômico do que aos caminhos por meio dos quais eles podem ser atingidos.

Trata-se da busca pelo ideal do american way of life ${ }^{173}$, transmitido nas escolas, nas famílias e nos locais de trabalho. No entanto, o idealismo da possibilidade do sucesso disponível a todos pode provocar graves consequências na formação dos membros da sociedade.

Isso porque

uma sociedade que entroniza o êxito, como valor supremo e desterra de sua visão qualquer indício de limitação, sofrimento, fracasso... como pode gerar indivíduos sãos que saibam assumir, como inerentes a sua condição de seres humanos, a limitação, o sofrimento ou mesmo o fracasso? Não pode, pois, estranhar, que muitos de seus jovens delinqüentes - jovens sobretudo - demonstrem um baixo umbral de tolerância a frustração, se só lhes educou no êxito, no triunfo a todo custo e a qualquer preço ${ }^{174}$.

A despeito de os fins buscados serem culturalmente os mesmos para todos os cidadãos, as oportunidades para que sejam concretizados encontram-se mal distribuídas, isto é, repartidas de forma desigual nas diversas camadas que conformam a moderna estrutura social.

Nesse contexto, o crime representa uma resposta a esta tensão cultural. É, pois, aqui que se possibilita o surgimento da anomia e do comportamento desviante ${ }^{175}$. É ele o resultado da contradição entre a estrutura social e a estrutura cultural ${ }^{176}$.

desviada. Tradução de Adolfo Crosa. Buenos Aires: Amorrortu, 1997 e FONTALVO, Jorge Restrepo. Criminología: un enfoque humanístico. 3. ed. Colômbia: Temis, 2002.

${ }^{173}$ Nas palavras de Dias e Andrade "o manifesto cultural americano - ensinado nas escolas, pregados nos púlpitos, divulgado na ficção literária ou cinematográfica - corresponde a um evangelho da procura, sem limites, do sucesso monetário. Sucesso que está ao alcance de todos: ponto é que se tenham as virtudes necessárias. A procura do sucesso, a luta pela subida na vida, ganha assim uma ressonância moral: não só corresponde a um direito mas vale também como um imperativo ético. O mito do sellf-made man tem como reverso o mito do self-unmade man e as estigmatizações negativas dos vencidos". Cf. DIAS; ANDRADE, DIAS, Jorge de Figueiredo; ANDRADE, Manuel da Costa. Criminologia: o homem delinqüente e a sociedade criminógena. 2 reimp. Coimbra: Coimbra Editora, 1997, p. 325.

${ }^{174}$ GARCÍA-PABLOS DE MOLINA, Antonio. La prevención del delito: reflexiones en torno a la denominada 'prevención situacional'. In: José Luis Guzmán Dalbora (Coord.). El penalista liberal. Buenos Aires: Hammurabi, 2004. p. 644.

${ }^{175}$ FERRO, Ana Luiza Almeida. Robert Merton e o funcionalismo. Belo Horizonte: Mandamentos, 2004.

${ }^{176}$ Ressalte-se a diferença na concepção de anomia proposta por Merton e por Durkheim, os dois grandes teóricos da teoria. Para este, ela deriva do fracasso em se alcançar os objetivos e as aspirações dos homens, as quais são ilimitadas. Já para aquele, ela nasce da discrepância entre os objetivos e meios legítimos para atingi-los, e as necessidades dos homens, bem que buscam finalidades limitadas, o que permite que a anomia possa existir no curso do normal funcionamento da sociedade Cf. MADRENAS I BOADAS, Carme. Una visión de la teoría de las subculturas criminales: Albert K. Cohen, y Richard A. Cloward y LLoyd e Ohlin. Doctrina Penal: Teoria y Práctica en las Ciências Penales, Buenos Aires, v. 5, n. 17-20, p. 435-461, 1982. 
A primeira representa os objetivos culturalmente definidos, de propósitos e interesses, mantidos como legítimos para todos os indivíduos. A segunda define, regula e controla os modos aceitáveis para se atingir os mencionados objetivos ${ }^{177}$.

É, pois, esta desconformidade entre os valores e normas vigentes e os objetivos culturais que torna um grupo social anômico ${ }^{178}$.

Já em nível individual, a tensão gerada pelo citado conflito pode ensejar cinco ordens de respostas diversas: conformidade, inovação, ritualismo, apatia e rebelião.

A escolha de um desses tipos de conduta depende do diverso grau de socialização do indivíduo e do modo como interiorizou os valores e normas sociais ${ }^{179}$.

Os conformistas são maioria na população. Aceitam os valores vigentes e os respeitam, mesmo sabendo que não poderão alcançar os benefícios almejados. São pessoas que incorporaram o ideal do trabalho como forma de ascensão social.

Os inovadores aceitam os fins sociais estabelecidos, mas inovam nos meios para neles chegarem, sendo aqui que nasce o comportamento criminoso típico. Fato é que "esta forma de adaptação pressupõe que os indivíduos tenham sido imperfeitamente socializados, de modo que abandonam os meios institucionais, enquanto retêm a aspiração ao êxito" $" 180$.

Os ritualistas não aceitam os objetivos dominantes, mas respeitam e cumprem os meios instituídos para atingi-los. Este tipo de adaptação individual, embora não represente um problema social, dada a observância das regras impostas, apenas não é tido como culturalmente preferido ${ }^{181}$.

Os apáticos negam tanto as metas sociais quanto os meios legítimos para se chegar a elas. São pessoas derrotistas, introspectivas e encontram-se abandonadas na sociedade, tais como bêbados, mendigos e viciados em drogas. É o tipo menos comum de adaptação social. Trata-se, na realidade, de uma fuga completa, na qual o conflito é eliminado e o indivíduo assocializado.

\footnotetext{
${ }^{177}$ MERTON, Robert K. Sociologia: teoria e estrutura. São Paulo: Mestre Jou, 1970.

${ }^{178}$ Nas palavras de Merton: "na verdade, minha hipótese central é que o comportamento aberrante pode ser considerado sociològicamente como um sintoma de dissociação entre as aspirações culturalmente prescritas e as vias socialmente estruturadas para realizar essas aspirações”. Cf. MERTON, Robert K. Sociologia: teoria e estrutura. São Paulo: Mestre Jou, 1970. p. 207.

${ }^{179}$ FERRO, Ana Luiza Almeida. Robert Merton e o funcionalismo. Belo Horizonte: Mandamentos, 2004.

${ }^{180}$ MERTON, Robert K. Sociologia: teoria e estrutura. São Paulo: Mestre Jou, 1970. p. 223.

${ }^{181}$ MERTON, Robert K. Sociologia: teoria e estrutura. São Paulo: Mestre Jou, 1970.
} 
Pode-se considerar que os indivíduos que adotam esse comportamento estão na sociedade, mas não são dela, ou seja, não pertencem a ela ${ }^{182}$.

Por fim, os rebeldes rechaçam os objetivos e os meios para ascender socialmente, pregando sejam substituídos por metas e caminhos alternativos. Encaram o sistema institucional como uma barreira à satisfação dos objetivos legitimados ${ }^{183}$.

Percebe-se que o conformista é o único que respeita em absoluto a estruturação social vigente. Todos os demais, de modo inverso, buscam soluções desviantes, tornandose indivíduos abstratamente sujeitos ao exercício do controle social contra si.

Importante se advertir que não são conceitos idênticos o de anomia e delinquência. No entanto, podem eles coincidirem se a anomia for orientada ao sócio-penalmente proibido $^{184}$.

Conforme exposto, o que se pode ressaltar sobre a teorização da anomia é a ocorrência de uma diferenciação em relação às ideias centrais das Escolas Positivista e de Chicago, já que para ambas o crime deriva de uma patologia, individual e social, respectivamente. No âmbito da teoria estrutural-funcionalista, e este é o seu pressuposto principal, ele é considerado um fator normal dentro de determinada estrutura social.

Trata-se, pois, de uma versão crítica das teorias funcionalistas em sociologia.

Embora tenha representado mais um degrau na evolução da ciência criminológica, a teoria da anomia comporta vicissitudes.

Equivoca-se Durkheim ao defender o abrandamento das punições ao longo do desenvolvimento das sociedades. A cruenta das reprimendas não se relaciona, em realidade, com as sociedades mecânicas, mas sim com os períodos monárquicos $\operatorname{absolutistas}^{185}$.

Ademais, estendeu ao crime suas conclusões acerca do aumento das taxas de suicídio em períodos de grandes transformações sociais, sem rigor científico.

\footnotetext{
${ }^{182}$ MERTON, Robert K. Sociologia: teoria e estrutura. São Paulo: Mestre Jou, 1970.

${ }^{183}$ MERTON, Robert K. Sociologia: teoria e estrutura. São Paulo: Mestre Jou, 1970.

${ }^{184}$ HERRERO, César Herrero. Criminologia. 2. ed. Madri: Dykinson, 2001.

185 VOLD, George B.; BERNARD, Thomas J. Theoretical Criminology. 3. ed. Nova Iorque: Oxford University Press, 1986.
} 
Atém-se a teoria a análises macrossociológicas e revela, por isso, elevados níveis de abstração. Apresenta um modelo linear da conduta delituosa, pelo qual a anomia conduz sempre ao desvio ${ }^{186}$.

$\mathrm{Na}$ crença de que se todos tivessem acesso aos fins e meios prescritos legitimamente na sociedade não haveria delinquência, evidencia-se uma tentativa simplista de homogeneização cultural. Esquece Merton das influências individuais que concorrem para a criminalidade.

A teoria da anomia, assim como o fez a ecologia criminal, dispensa especial atenção e importância às estatísticas, sem considerar que elas não necessariamente representam a realidade da sociedade. Elas demonstram, e a criminologia anômica acredita, que as classes desfavorecidas economicamente delinquem mais, mas não destacam o papel do controle social na formação desses dados ${ }^{187}$.

Do erro mencionado, decorre a concentração de seus estudos na criminalidade das classes mais pobres da sociedade.

Embora tenha surgido em oposição ao paradigma positivista, dele não conseguiu desvincular-se, incorrendo ambos em erros comuns: preocupação com a ordem e progresso, crença no consenso social, pretendida neutralidade e separação entre sujeito e objeto. Porém, trata-se agora da ideologia da burguesia da sociedade industrial desenvolvida e não mais da nascente burguesia.

Evidencia-se, em conclusão, uma vocação conservadora, legitimadora do status $q u o$, pois analisa o crime apenas quando se manifesta e não quando é gerado ${ }^{188}$.

Balanceados seus acertos e vicissitudes, e seguindo a orientação classista que inaugurou, ganha fôlego a teoria das subculturas delinquentes.

\subsubsection{Teoria das Subculturas Delinquentes}

Antes de adentrar na explicação criminológica das subculturas delinquentes, mister explanar em que consiste uma subcultura, bem como a palavra da qual advém, cultura.

\footnotetext{
${ }^{186}$ LARRAURI PIJOAN, Elena. La herencia de la criminología crítica. 2. ed. Madri: Siglo veintiuno de España, 2000.

${ }^{187}$ Como já mencionado no presente trabalho, a fidedignidade das estatísticas criminais só será seriamente questionada pela teoria criminológica do labelling approach.

${ }^{188}$ GARCÍA-PABLOS DE MOLINA, Antonio. Criminologia: uma introdução a seus fundamentos teóricos. Tradução de Luiz Flávio Gomes. São Paulo: Revista dos Tribunais, 1992.
} 
Essa necessidade decorre do fato de que ambos os termos podem ser encarados sob o ponto de vista de variadas áreas do conhecimento humano, tal qual a antropologia, filosofia, história ou sociologia, o que enseja um maior grau de dificuldade na sua definição.

Ademais, seu significado emanado do senso comum, já tão amplamente utilizado como a característica da pessoa que tem conhecimentos, que é estudada, não deve ter lugar nesta teorização.

Pode-se dizer, atendo-se a sua significação sociológica, que a cultura representa o núcleo de valores e padrões de conduta, aceitos pela maioria da sociedade, os quais atuam como critérios orientadores de seu comportamento.

Numa concepção consensual da organização social, é ela elemento essencial para que determinada coletividade constitua-se numa sociedade ${ }^{189}$.

Assim, estende-se a todos os modelos de ação coletiva, identificáveis por meio das palavras e condutas dos membros de uma dada comunidade, dinamicamente transmitidos de geração em geração e dotados de durabilidade ${ }^{190}$.

Derivam dela os conceitos de subcultura e contracultura. Esta é representada por modelos valorativos e comportamentais diametralmente opostos ao da cultura dita dominante. Representam a negação e a consequente reação a ela. Já as subculturas não contrariam o núcleo cultural dominante ${ }^{191}$.

São normas e valores que se encontram no âmbito de alcance do jovem da classe trabalhadora, aos quais ele adere ao crer que permitirão a obtenção dos modelos sociais pretendidos $^{192}$.

Importante salientar que se adota aqui, como título deste item, o termo teoria das subculturas delinquentes, no plural, tendo em vista as diferentes explicações culturalistas dadas ao fenômeno da delinquência. Assim, levando-se em consideração a atenção dada por Albert Cohen a prática subcultural dos jovens, relevante para o presente trabalho, é sua teoria que será analisada mais pormenorizadamente ${ }^{193}$.

189 SHILS, Edward. Sociedade e sociedades: o ponto de vista macrossociológico. Tradução de Octavio Mendes Cajado. In: PARSONS, Talcott (Org.). A Sociologia Americana. São Paulo: Cultrix, 1970.

${ }^{190}$ DIAS, Jorge de Figueiredo; ANDRADE, Manuel da Costa. Criminologia: o homem delinqüente e a sociedade criminógena. 2. reimp. Coimbra: Coimbra Editora, 1997.

${ }^{191}$ A existência de subculturas pressupõe haja um conjunto de valores culturais dominantes, consensuais.

192 BERGALLI, Roberto. Perspectiva sociológica: desarollos ulteriores. In: ; BUSTOS RAMÍREZ, Juan; MIRALLES, Teresa. El Pensamiento Criminológico: un análisis crítico. Bogotá: Temis, 1983. v. 1.

${ }^{193}$ Podem ser apontadas como teorias subculturais a da classe média, a da lower-class de Walter Miller e a da oportunidade diferencial de Cloward e Ohlin. Sobre o assunto ver: DIAS, Jorge de Figueiredo; ANDRADE, 
Cohen retrata o problema do status na sociedade norte-americana, o qual se reflete na distribuição dos indivíduos em gangues subculturais, formadas, majoritariamente, por pessoas do sexo masculino, jovens, provenientes das classes trabalhadoras ${ }^{194}$. Sua explicação para a prática criminal bem se relaciona com a ofertada pela teoria da anomia, desenvolvendo inclusive uma relação de compatibilidade com ela ${ }^{195}$.

Em comum tem-se que ambas contribuíram para a relativização do sistema de valores e regras sancionados pelo Direito Penal, ao mostrarem que não são as normas postas a exata expressão dos valores pacificamente vigentes na sociedade ${ }^{196}$; partem da adesão dos cidadãos aos valores do american dream $^{197}$; apresentam a delinquência como resposta aos problemas sociais; creem que os jovens são impelidos a prática criminosa por estados emocionais negativos, tais como frustração ou ressentimento; acreditam na tensão social gerada pelo estabelecimento de objetivos sociais e meios para se atingi-los e são orientadas pelo conceito de classe.

Nas palavras de Cohen, as

características da sociedade norte-americana são calculadas para elevar ao máximo a ambição e ministrar às pessoas incentivo para se prepararem, trabalharem com afinco, buscarem a responsabilidade. Êsses níveis de aspiração, constantemente elevados, ajudam a explicar a assombrosa produtividade da sociedade norte-americana. Ajudam também a produzir o descontentamento, a discrepância entre o que se procura e o que se consegue ${ }^{198}$.

O indivíduo originário das camadas sociais menos abastadas toma consciência dos valores vigentes na sociedade e da impossibilidade de alcançá-los devido ao seu status social inferior. Em vista disso, opta por associar-se a grupos cujos valores dominantes são diversos - subculturais - e passa a preocupar-se com o respeito às regras impostas por este segmento, ainda que ilícitas aos olhos da sociedade.

Manuel da Costa. Criminologia: o homem delinqüente e a sociedade criminógena. 2 reimp. Coimbra: Coimbra Editora, 1997.

${ }^{194}$ COHEN, Albet K. Delinquent boys. Londres: Routledge \& Kegan Paul, 1958.

${ }^{195}$ Infere-se a existência de uma relação de continuidade entre a teoria anômica e as subculturais, tendo em vista que seus postulados teóricos não são excludentes, podendo, portanto, serem compatibilizados. Isto porque, enquanto esta estuda a relação funcional do desvio com as estruturas sociais, aquela se escusa deste ponto, ocupando-se apenas da origem e transmissão de uma subcultura delinquente.

${ }^{196}$ MADRENAS I BOADAS, Carme. Una visión de la teoría de las subculturas criminales: Albert K. Cohen, y Richard A. Cloward y LLoyd e Ohlin. Doctrina Penal: Teoria y Práctica en las Ciências Penales, Buenos Aires, v. 5, n. 17-20, p. 435-461, 1982.

${ }^{197}$ Neste ponto refere-se mais especificamente a teoria da anomia formulada por Robert Merton.

${ }^{198}$ COHEN, Albert K. Comportamento aberrante e seu controle. Tradução de Octavio Mendes Cajado. In: PARSONS, Talcott (Org.). A Sociologia Americana. São Paulo: Cultrix, 1970.p. 279. 
A conduta delinquente é considerada correta para os padrões da subcultura, especialmente porque taxada como inadequada pelas normas comportamentais da cultura dominante ${ }^{199}$.

Assim, esses agrupamentos negam legitimidade a determinadas normas de conduta aceitas pela maioria, e a atribui a outras, definidas como ilegítimas pelas instâncias oficiais $^{200}$.

Nesse contexto, as subculturas criminais funcionam como

mecanismos substitutivos de participação social (mini sociedades de troca) ou sucedâneos de uma frustrada participação que a sociedade oficial adulta negou ao jovem, obrigando-o a se integrar em subgrupos alternativos ${ }^{201}$.

Com efeito, a diferenciação das concepções sociais existentes entre os grupos, numa sociedade na qual se identifica a presença de valores culturais dominantes, possibilita as formações contra e subculturais, centradas em valores alternativos, e adotando estilos de vida bastante variados ${ }^{202}$.

Ao enxergar na sociedade a existência de diversos códigos comportamentais e não apenas daquele adotado formalmente pelo Estado por intermédio do Direito Penal, a teoria questiona o princípio da culpabilidade dos autores do ilícito ${ }^{203}$.

Percebe-se, pois, que o mesmo sistema valorativo, dito dominante, incidindo sobre pessoas com capacidades distintas para alcançá-los, gera ao mesmo tempo delinquência e conformidade $^{204}$. Os indivíduos são fortemente motivados a se conformarem com os padrões culturais dominantes, sendo somente possível a emergência de grupos subculturais por meio da efetiva interação de indivíduos com similares problemas de adaptação às regras constituídas ${ }^{205}$.

${ }^{199}$ COHEN, Albert K. Delinquent boys. Londres: Routledge \& Kegan Paul, 1958.

${ }^{200}$ MADRENAS I BOADAS, Carme, Una visión de la teoría de las subculturas criminales: Albert K. Cohen, y Richard A. Cloward y LLoyd e Ohlin. Doctrina Penal: Teoria y Práctica en las Ciências Penales, Buenos Aires, v. 5, n. 17-20, p. 435-461, 1982.

201 GARCÍA-PABLOS DE MOLINA, Antonio. La prevención del delito: reflexiones en torno a la denominada 'prevención situacional'. In: José Luis Guzmán Dalbora (Coord.) El penalista liberal. Buenos Aires: Hammurabi, 2004. p. 644.

${ }^{202}$ BIDWELL, Charles E. A juventude na sociedade moderna. Tradução de Octavio Mendes Cajado. In: PARSONS, Talcott (Org.). A Sociologia Americana. São Paulo: Cultrix, 1970. Ressalte-se que a subcultura é uma solução de grupo e não individual.

${ }^{203}$ BARATTA, Alessandro. Criminologia e Dogmática Penal. Passado e futuro do modelo integral da Ciência Penal. Revista de Direito Penal, Rio de Janeiro, n. 31, p. 5-37, jan.Ijun. 1981.

${ }^{204}$ MADRENAS I BOADAS, Carme. Una visión de la teoría de las subculturas criminales: Albert K. Cohen, y Richard A. Cloward y LLoyd e Ohlin. Doctrina Penal: Teoria y Práctica en las Ciências Penales, Buenos Aires, v. 5, n. 17-20, p. 435-461, 1982.

${ }^{205}$ COHEN, Albet K. Delinquent boys. Londres: Routledge \& Kegan Paul, 1958. 
Tais sujeitos enxergam os valores pregados pela subcultura como mais efetivos para a solução de seu problema de adaptação e acabam, por eles e por meio deles, elevando seus companheiros a símbolos de referência, dos quais esperam apoio e suporte ${ }^{206}$.

O problema que motiva as formações subculturais, como já mencionado, é o de status, definido por Cohen como o desejo de obtenção de respeito aos olhos dos demais cidadãos. A formação de uma subcultura, com regras próprias, diversas daquelas que os excluem da sociedade, é a solução do grupo para atingir a posição almejada ${ }^{207}$.

Cohen explica alguns dos fatores que fazem nascer nas crianças das classes humildes a certeza de sua inadaptação, baseado no tratamento social por elas recebido. Assevera que esses infantes já nascem carregando a classificação social, indesejada, ostentada por seus pais, o que pode provocar de antemão uma sensação de vergonha perante as crianças de classe média. Em vista dos parcos recursos de sua família, os infantes não costumam ser convidados a participar de atividades que exijam um aparato material pelo qual elas não podem pagar; se convidados, é provável que não aceitem por medo ou vergonha, e se aceitarem é menos provável que consigam retribuir ao convite, construindo uma relação, com seus colegas de classe média, em que não há reciprocidade ${ }^{208}$.

Desta feita, a criança acaba interiorizando sentimentos de inferioridade, ressentimento e hostilidade, no que concerne a sua interação com a sociedade.

Cohen critica o uso da expressão "crime dos jovens" 209 para se referir aos atos ilícitos praticados por esta parcela da população, tendo em vista as conotações errôneas que ela pode provocar. Ela sugere, entre outras impropriedades, que existem dois tipos de criminoso, o jovem o e velho, mas apenas um tipo de crime, bem como que os significados e motivos que impulsionam a delinquência são os mesmos, independentemente da idade dos autores ${ }^{210}$.

Elucidando de uma vez a confusão de significados, Cohen assevera que delinquência, quando subcultural, caracteriza-se pelo não-utilitarismo, malícia e negativismo.

\footnotetext{
${ }^{206}$ COHEN, Albet K. Delinquent boys. Londres: Routledge \& Kegan Paul, 1958. ${ }^{207}$ COHEN, Albet K. Delinquent boys. Londres: Routledge \& Kegan Paul, 1958.

${ }^{208}$ COHEN, Albet K. Delinquent boys. Londres: Routledge \& Kegan Paul, 1958.

${ }^{209}$ Em original: “juvenile crime”. Cf. COHEN, Albet K. Delinquent boys. Londres: Routledge \& Kegan Paul, 1958. p. 24.

${ }^{210}$ COHEN, Albet K. Delinquent boys. Londres: Routledge \& Kegan Paul, 1958.
} 
A delinquência é encarada pelos jovens como uma forma de recreação, uma maneira de se firmarem perante o seu grupo (não-utilitarismo), por meio da qual sentem prazer por deixar as vítimas numa situação vexatória ou desconcertante e ao romper com tabus sociais (malícia); são hostis aos não-membros do grupo o que inclui o mau comportamento escolar e o desrespeito a adultos e crianças $^{211}$.

De um modo geral, as gangues juvenis subculturais são versáteis no tocante à variedade dos delitos que praticam, autônomas em relação aos demais grupos sociais, estabelecendo com eles apenas relações de indiferença, hostilidade ou rebelião, embora entre seus membros se edifique uma convivência leal e solidária, e composta por jovens desinteressados por atividades culturais ou aquisição de conhecimentos ${ }^{212}$.

A delinquência por elas produzida não pode ser comparada com a criminalidade organizada adulta. Esta pressupõe a existência de uma estrutura e de uma distribuição de atividades entre seus componentes. Já aquela, formada geralmente por jovens adeptos de determinada subcultura, visa à prática de infrações espontâneas, não havendo organização no tocante à distribuição de papéis dentro do grupo ${ }^{213}$.

De maneira geral, as teorias subculturais intencionam combinar um enfoque macro dos problemas criados pelas estruturas, com um enfoque micro, de onde se localiza e como se aprendem os comportamentos delitivos ${ }^{214}$.

Obteve êxito ao apontar, ainda que de forma incipiente, as diferenças culturais existentes na sociedade, pregando ainda o respeito às autonomias culturais dos diversos grupos sociais. Porém, não conseguiu desvincular-se do modelo consensual da sociedade, no qual os valores culturais vigentes são frutos da concordância dos cidadãos e o fato de não se conseguir atingi-los desencadeia as ações criminosas. Além disso, limitou a explicação criminológica, dando conta da análise apenas das manifestações delinquentes subculturais.

Foi a teoria das subculturas delinquentes que encerrou o ciclo de produção de construções criminológicas baseadas no modelo de consenso social, demonstrando-se não ser mais ele condizente com as realidades contemporâneas das sociedades.

${ }^{211}$ COHEN, Albet K. Delinquent boys. Londres: Routledge \& Kegan Paul, 1958.

${ }^{212}$ Para Cohen esta última é uma característica dos jovens das classes sociais mais baixas, e não apenas dos que pertencem a grupos subculturais. Cf. COHEN, Albet K. Delinquent boys. Londres: Routledge \& Kegan Paul, 1958.

${ }^{213}$ BARBERO SANTOS, Marino. La delincuencia juvenil en España: imagen y realidad. Doctrina Penal: Teoría y Práctica en las Ciencias Penales, Buenos Aires, v. 6, n. 21-24, p. 417-436, 1983.

${ }^{214}$ LARRAURI PIJOAN, Elena. La herencia de la criminología crítica. 2. ed. Madri: Siglo veintiuno de España, 2000. 


\subsubsection{Criminologia do Conflito}

Conflitual é a concepção do grupo social cujos membros creem em valores distintos, não havendo concordância em relação ao que é desejado por todos. A coesão social se alcança, pois, mediante a coerção dos membros da sociedade.

A diversidade, a ausência de uniformidade e a comunhão de valores são as marcas das modernas sociedades de conflito ${ }^{215}$.

As normas de controle aparecem como reflexo exclusivo dos interesses de apenas uma parcela desse grupo e como meio de dominação e controle das classes subalternas. De fato, o projeto jurídico-político especificamente burguês é o de alcançar o máximo possível da capacidade de administrar pacificamente os $\operatorname{conflitos}^{216}$.

Entende-se que o que precisa ser modificado é o sistema, e não o ser humano ${ }^{217}$.

Considera-se que o Código Penal não é o único conjunto normativo a ser obedecido, sendo que compete ele com outras normas, variáveis em cada grupo social, o que identifica a marca registrada das modernas sociedades - a superação do monismo cultural pelo pluralismo axiológico ${ }^{218}$.

O Estado, então, é o órgão representativo dos valores e dos interesses do grupo com poder suficiente para controlar suas operações ${ }^{219}$, não expressando as normas por ele impostas modelos aceitos por todos ou corretos a priori.

As teorias do conflito, pois, "localizam as verdadeiras variáveis do processo de definição e seleção nas relações de poder dos grupos sociais, partindo do dado da estratificação social e dos conflitos de interesses"220.

São características gerais dessa forma de compreensão da coerção social a crença de que a sociedade está sempre sujeita a processos de mudança; a ubiquidade do conflito social, apresentando-se no contexto coletivo dissenso e conflito; a assertiva de que todos os

${ }^{215}$ AKERS, Ronald L. Criminological Theories: introduction and evaluation. 2. ed. Los Angeles: Roxbury, 1997.

${ }^{216}$ MISSE, Michel. Sobre o "conceito" de conflito social. In: ROSA, F. A. de Miranda (Org.). Direito e Conflito social. Rio de Janeiro: Zahar, 1981.

${ }^{217}$ KAISER, Gunter. Introducción a la Criminología. Tradução de José Arturo Rodríguez Núñez. 7. ed. Madri: Dykinson, 1988.

${ }^{218}$ SHECAIRA, Sérgio Salomão. Criminologia. 2. ed. rev. São Paulo: Revista dos Tribunais, 2008.

219 VOLD, George B.; BERNARD, Thomas J. Theoretical Criminology. 3. ed. Nova Iorque: Oxford University Press, 1986.

${ }^{220}$ GARCÍA-PABLOS DE MOLINA, Antonio. La normalidad del delito y el delincuente. Revista de la Facultad de Derecho de la Universidad Complutense, Madri, n. 11, p. 325-346, jun. 1986. p. 343. 
elementos sociais contribuem para a desintegração e mudança da sociedade; e a aceitação de que a sociedade é baseada na coerção de uns pelos outros ${ }^{221}$.

Sua oposição ao modelo consensual da sociedade não se originou tanto do reexame das teorias criminológicas nele baseadas, mas sim na observação de acontecimentos reais que permitiram colocar em dúvida a existência do consenso ${ }^{222}$.

Temeroso defender a existência de um único modelo de conflito, dados seus diferentes autores e concepções da dominação. Mais correto, pois, é assumir a existência de modelos de conflito ${ }^{223}$.

Para Marx a coerção social tem por base o conflito de classes, para Dahrendorf sua causa é a distribuição diferenciada da autoridade, para Sellin o conflito tem como atores grupos sociais que adotam normas comportamentais divergentes e para Vold ele se apresenta na luta de interesses entre os distintos grupos sociais.

Na visão de Marx a sociedade é construída sob a dialética da luta entre as classes sociais, representando ela a expressão humana ou social do conflito das forças econômicas. Nesta disputa classista identificam-se dois pólos antagônicos - burguesia e proletariado, ou capitalistas e trabalhadores - em relação dialética.

O Estado, bem como a lei e o sistema de justiça dele emanados, é considerado instrumento da batalha entre as classes, sendo o proletário dominado por suas instituições. Por meio desse aparato a classe dominante impõe seus valores à classe inferior e obriga sua observância.

Sua concepção da sociedade exerce grande influência na teoria crítica da Criminologia $^{224}$.

Para Dahrendorf a autoridade está sempre associada a posições ou papéis sociais, fazendo parte mesmo da estrutura social. Os conflitos entre os grupos manifestam-se sempre que ela é exercida no interior de associações imperativamente coordenadas, tais como o são o Estado ou uma empresa.

${ }^{221}$ DAHRENDORF, Ralf. As classes e seus conflitos na sociedade industrial. Tradução de José Viegas. Brasília: Editora Universidade de Brasília, 1982. Note-se aqui, como pano de fundo para a antinomia consenso-conflito, o significado das normas através das quais uma sociedade é construída. A teoria consensualista informa que são elas representativas dos valores aceitos pacificamente por todo o corpo social, enquanto que para a conflitiva são representações dos interesses das classes que detêm o poder.

${ }^{222}$ TAYLOR, Ian; WALTON, Paul; YOUNG, Jack. La Nueva Criminología: contribución a una teoria social de la conducta desviada. Tradução de Adolfo Crosa. Buenos Aires: Amorrortu, 1997.

${ }^{223}$ Para García-Pablos de Molina as teorias do conflito podem ser divididas em três grupos distintos. São elas, a de conflito cultural, social e de corte marxista. Cf. GARCÍA-PABLOS DE MOLINA, Antonio. Tratado de Criminología. 2. ed. Valência: Tirant lo blanch, 1999.

${ }^{224}$ Essa teoria será analisada no item 1.3.2.2 do presente trabalho. 
Autoridade encontra-se estreitamente vinculada a dominação e sujeição, sendo a partir dela que surgem essas relações. O dominador deseja a manutenção da estruturação social que lhe confere autoridade, enquanto o outro deseja mudar a condição social que lhe priva dela.

Assim, em seu modelo de coerção social, a distribuição da autoridade nas associações é a causa da formação de grupos de conflito e, sendo dicotômica a relação que produz, desencadeia a formação de dois grupos de conflito - os dominadores e os dominados 225 .

O poder, pois, é que gera desigualdade e conflito $^{226}$.

O autor apresenta uma visão positiva das funções do conflito, encarando-o como bom e desejável para o sistema. Crê que ele permite e impulsiona mudanças históricas e desenvolvimento ${ }^{227}$.

Importante destacar a interessante análise do autor sobre a ressocialização. Dahrendorf questiona seu real significado, já que a sociedade para a qual os ex-detentos deveriam retornar nem sequer existe. Assevera que as prisões não são um lugar de disciplina e ordem, aptos a melhorarem o indivíduo, sendo elas, na realidade, o espelho da sociedade ao redor, com um elemento considerável de classe inferior. Ademais, crê que mesmo se os infratores, durante sua reclusão, fossem informados sobre o valor de uma vida ordenada eles encontrariam poucos elementos em seus mundos reais que confirmassem esses textos escolares poéticos 228 .

Para Sellin, nas sociedades primitivas as normas de conduta eram aceitas e incorporadas por todos, dada a homogeneidade de seus membros. Em vista dessa semelhança entre os sujeitos, raras eram as violações das regras, as quais se controlavam pelo rigor da opinião pública.

No entanto, as modernas sociedades ocidentais têm como marcante a heterogeneidade, uma vez que são formadas por grupos com valores e características distintas, muitas vezes opostas.

${ }^{225}$ DAHRENDORF, Ralf. As classes e seus conflitos na sociedade industrial. Tradução de José Viegas. Brasília: Editora Universidade de Brasília, 1982.

${ }^{226}$ DAHRENDORF, Ralf. O conflito social moderno. Um ensaio sobre a política da liberdade. Tradução de Renato Aguiar e Marco Antônio Esteves da Rocha. Rio de Janeiro: Jorge Zahar; São Paulo: Edusp, 1992.

${ }^{227}$ DAHRENDORF, Ralf. As classes e seus conflitos na sociedade industrial. Tradução de José Viegas. Brasília: Editora Universidade de Brasília, 1982.

${ }^{228}$ DAHRENDORF, Ralf. A lei e a ordem. Tradução de Tâmara D. Barile. Brasília: Instituto Tancredo Neves, 1987. 
O autor entende que as atitudes fundamentais da pessoa são por ela incorporadas tendo em vista as relações interpessoais das quais participa no decorrer de seu desenvolvimento e reforçadas pelos apegos emocionais que constitui ao longo da vida. Crê ainda serem mais relevantes as primeiras experiências, vivenciadas durante a infância, do que as mais tardias, vez que a família é a mais importante de todas as instituições sociais.

Os valores cultivados no seio familiar, a disciplina por ela imposta, os castigos por ela aplicados são, pois, elementos que influenciarão a conduta social futura do sujeito ${ }^{229}$.

Assim, defende o Sellin que os adultos tendencialmente seguirão os valores apreendidos ao longo de sua vida, principalmente na infância, ainda que estes não coincidam com os ostentados pelos demais membros da sociedade, ou mesmo pelo Direito Penal $^{230}$.

Aqui, então, fica clara sua tese de que o conflito se realiza entre os grupos sociais cujos comportamentos são discrepantes.

Instituições impessoais impõem e fiscalizam o cumprimento de regras ditadas pelos grupos sociais detentores do poder, sendo expressa, na severidade das reprimendas, a mensuração da importância dada à conduta, pelos grupos dominantes ${ }^{231}$.

As regras penais não são as únicas normativas a serem obedecidas, tendo que competir por espaço com outras, variáveis em cada grupo social, as quais as pessoas são leais, sem a necessidade de sua obrigatoriedade pelo Estado ${ }^{232}$.

Esses conflitos de atitude da sociedade moderna em relação às condutas delituosas etiquetadas pelo Estado faz com que o efeito intimidativo da pena seja extremamente variável. Há pessoas que preferem seguir as regras de seus grupos, mesmo que estejam elas em desacordo com a lei penal e independentemente das sanções previstas pelo Estado em caso de violação. Elas se preocupam e sofrem mais com a possibilidade de uma punição imposta pelo seu próprio grupo, caso descumpram suas regras, do que com a determinada pela lei penal, restando comprometido o seu poder de intimidação ${ }^{233}$.

${ }^{229}$ SELLIN, Thorsten. L'effet intimidant de la peine: étude de sociologie criminelle. Revue de Science Criminelle et de Droit Penal Comparé, Paris, n. 4, p. 579-593, oct.ldec. 1960.

${ }^{230}$ SELLIN, Thorsten. L'effet intimidant de la peine: étude de sociologie criminelle. Revue de Science Criminelle et de Droit Penal Comparé, Paris, n. 4, p. 579-593, oct.ldec. 1960.

${ }^{231}$ SELLIN, Thorsten. Le sociologue et le problème du crime. Revue de Science Criminelle et de Droit Penal Comparé, Paris, n. 4, p. 527-539, oct./dec. 1950.

${ }^{232}$ SELLIN, Thorsten. L'effet intimidant de la peine: étude de sociologie criminelle. Revue de Science Criminelle et de Droit Penal Comparé, Paris, n. 4, p. 579-593, oct.ldec. 1960.

${ }^{233}$ SELLIN, Thorsten. L'effet intimidant de la peine: étude de sociologie criminelle. Revue de Science Criminelle et de Droit Penal Comparé, Paris, n. 4, p. 579-593, oct.ldec. 1960. 
$\mathrm{Na}$ formulação de Vold o conflito se expressa na luta de interesses entre os diferentes grupos constituídos em dada sociedade.

Os agrupamentos entre pessoas se formam e se dissolvem tendo em vista a aparição ou extinção de interesses comuns entre elas. A participação e a colaboração na solução de seus problemas aumentam a lealdade e a identificação entre o indivíduo e seu grupo, tornando-se emocional.

No momento em que essas aspirações passam a ser divergentes, os grupos se enfrentam e entram em conflito pela defesa das mesmas.

Para o autor, a disputa entre elas alcança especial visibilidade na escolha da política legislativa. Ao obter êxito em transformar seus valores em leis, a organização passa a exercer o controle sobre o poder da polícia. Há certamente uma tendência a que seus membros obedeçam a essas normas, as quais coadunam com seus interesses. Diversamente, nasce uma grande possibilidade de que a organização oposta, que perdeu a luta pelo poder, incida na prática ilícita, tendo em vista a não concordância com as normas constituídas. Nesse diapasão, “o comportamento criminoso é o comportamento dos grupos menos poderosos, os quais não têm poder suficiente para promover e defender seus interesses e propósitos no processo legislativo"234.

Portanto, o conflito de interesses dos diferentes grupos e suas lutas pelo controle do poder estão, para Vold, no âmago da organização política de dada sociedade. É ele, aliás, um dos principais processos sociais a colaborar com a continuidade do funcionamento da sociedade ${ }^{235}$.

Evidencia-se, diante do exposto até aqui, que a Criminologia do conflito pode direcionar seu enfoque ao comportamento da lei penal ou ao comportamento criminal. No tocante ao primeiro ponto, considera-se que os comportamentos típicos das classes menos poderosas têm uma tendência maior a serem criminalizados e os pertencentes a este estrato social têm maiores chances de serem processados. Em relação ao segundo, defende-se que a falta de poder, ou o menos poder, é uma característica estrutural associada ao

234 VOLD, George B.; BERNARD, Thomas J. Theoretical Criminology. 3. ed. Nova Iorque: Oxford University Press, 1986. p. 274.

${ }^{235}$ VOLD, George B.; BERNARD, Thomas J. Theoretical Criminology. 3. ed. Nova Iorque: Oxford University Press, 1986. 
desenvolvimento de padrões de comportamento tendencialmente definidos e processados oficialmente como criminosos ${ }^{236}$.

Agora não há mais como negar que, de fato, o que existe na sociedade é um amplo dissenso, ainda que, por vezes, camuflado de consenso. As classes dominantes são quem impõem valores às classes subalternas, por meio dos aparatos ideológicos da sociedade, tais como família, escola e meios de comunicação, valores esses que ainda recebem proteção do mecanismo repressivo institucionalizado pelo Estado, representados, entre outras instituições, pela policia e o pelo cárcere ${ }^{237}$.

Ao assumir essa nova visão da organização social, a Criminologia muda radicalmente seu enfoque de estudo. Desinteressa-se pelas causas da criminalidade e passa a ocupar-se do porquê da definição de determinada conduta como ilícita.

O crime torna-se uma função dos conflitos existentes, sem que por isso estes devam reputar-se como nocivos ou disfuncionais ${ }^{238}$.

Privilegia-se ainda o estudo das criminalizações primária e secundária, buscando analisar o papel das instituições perante a sociedade e a criminalidade ${ }^{239}$.

Classe social, raça, sexo, idade, etnia, situação de desvantagem econômica, entre outros componentes que denotam a posição ocupada pelo indivíduo em sua sociedade, determinam os que têm mais chances de serem apreendidos e punidos ${ }^{240}$. Assim, destaca-se a existência de uma relação entre o poder e as taxas oficiais de criminalidade ${ }^{241}$.

O novo modelo que desponta propugna, pois, uma nova Criminologia, concebida como teoria radical da desviação e crítica do sistema penal.

A Criminologia do conflito atinge seu auge na década de 1960, com a formulação da primeira teoria contempladora desse modelo, denominada labelling approach, seguida, na década de 1970, pelas denominadas críticas ou radicais. Com o aparecimento das

${ }^{236}$ VOLD, George B.; BERNARD, Thomas J. Theoretical Criminology. 3. ed. Nova Iorque: Oxford University Press, 1986.

${ }^{237}$ LARRAURI PIJOAN, Elena. La herencia de la criminología crítica. 2. ed. Madri: Siglo veintiuno de España, 2000.

${ }^{238}$ GARCÍA-PABLOS DE MOLINA, Antonio. Tratado de Criminología. 2. ed. Valência: Tirant lo blanch, 1999.

${ }^{239}$ DIAS, Jorge de Figueiredo; ANDRADE, Manuel da Costa. Criminologia: o homem delinqüente e a sociedade criminógena. 2 reimp. Coimbra: Coimbra Editora, 1997.

${ }^{240}$ AKERS, Ronald L. Criminological Theories: introduction and evaluation. 2. ed. Los Angeles: Roxbury, 1997.

${ }^{241}$ VOLD, George B.; BERNARD, Thomas J. Theoretical Criminology. 3. ed. Nova Iorque: Oxford University Press, 1986. 
citadas teorizações é que se faz a passagem da Criminologia liberal para a crítica e se assume definitivamente a concepção conflitiva da sociedade ${ }^{242}$

\subsubsection{Teoria do Labelling Approach}

Em meados da década de 1960 tiveram início diversos movimentos sociais de viés desconstrucionista. Originaram-se culturas contestatórias no âmbito social, bem como no âmago de algumas ciências específicas, tais como o Direito, a Psiquiatria, a Sociologia e a Criminologia.

Esse impulso desestruturador insere-se no horizonte da radicalização social, política e cultural e da intensa explosão de conflituosidade que dominou o período, não se cingindo apenas aos campos penal e criminológico. O contexto histórico que o autoriza é o da crise, nas sociedades capitalistas, do Estado de Bem-estar social ${ }^{243}$.

É a época da luta estudantil contra a intervenção norte-americana no Vietnã, das manifestações contra a segregação racial encabeçadas por Luther King, do movimento feminista e da proposição de um novo estilo de vida não consumista.

$\mathrm{Na}$ base da ciência criminológica, o que se pretendia era debilitar as teorias até o momento dominantes, de cunho etiológico e individualista, por meio do fornecimento de novas explicações acerca dos fenômenos criminais e das estruturas de controle social ${ }^{244}$.

A existência, na Criminologia tradicional, de um "estado de sítio" permanente contra o crime, excessivamente oneroso em termos materiais e humanos, acelerou a busca por soluções de natureza diversa das até então existentes ${ }^{245}$.

Aliado a isso, surge no período uma desviação típica, relacionada com a revolução cultural que se desenhava, representada pela prática de delitos sem vítima, entre os quais se incluíam delitos políticos, manifestações pacifistas e campanhas em favor dos direitos humanos, os quais a Criminologia tradicional não tinha condições de explicar.

\footnotetext{
${ }^{242}$ BARATTA, Alessandro. Criminologia e Dogmática Penal. Passado e futuro do modelo integral da Ciência Penal. Revista de Direito Penal, Rio de Janeiro, n. 31, p. 5-37, jan.Ijun. 1981.

${ }^{243}$ ANDRADE, Vera Regina Pereira de. A ilusão da segurança jurídica: do controle da violência à violência do controle penal. 2. ed. Porto Alegre: Livraria do Advogado, 2003.

${ }^{244}$ COHEN, Stanley. Esceptismo intelectual y compromiso político: la Criminología Radical. Delito y sociedad: Revista de Ciencias Sociales, Buenos Aires, v. 3, n. 4-5, p. 3-31, 1993 I1994.

${ }^{245}$ DIAS, Jorge de Figueiredo; ANDRADE, Manuel da Costa. Criminologia: o homem delinqüente e a sociedade criminógena. 2 reimp. Coimbra: Coimbra Editora, 1997.
} 
Desta feita, pode se verificar que "na década de sessenta o inimigo estava claro: a criminologia positivista"246.

A grande modificação que inaugura, e que faz a teoria do labelling approach $^{247}$ distinta de suas antecessoras, é a ideia de que para se entender o sentido social dos comportamentos é imprescindível que se examinem as reações sociais que dele decorrem $^{248}$.

Isso porque é somente devido às respostas negativas que recebe dos membros da sociedade que uma conduta é qualificada como adequada ou inadequada, desviada ou não desviada. Não está na sua natureza a determinação de seu acerto ou da sua licitude, mas sim nas manifestações que enseja.

Insere-se aqui o elemento do poder, antes negligenciado pela ciência criminológica. Nas sociedades modernas, conflituais, percebe-se que a imposição das regras sociais é feita pelo grupo com poder para ditar tais normas, sendo dessa maneira realizada a eleição dos valores tutelados pelos órgãos estatais. Também é com base nele que se elegem, entre os violadores da norma, os que serão por isso responsabilizados ${ }^{249}$.

Em decorrência da mencionada situação, os teóricos do etiquetamento defendem a importância de se estudar o processo de definição por meio do qual a sociedade interpreta um comportamento como desviado e reage a ele ${ }^{250}$.

Desse modo,

a criminalidade se revela, principalmente, como um status atribuído a determinados indivíduos mediante um duplo processo: a 'definição' legal de crime, que atribui à conduta o caráter criminal e a 'seleção' que etiqueta e estigmatiza um autor como criminoso entre todos aqueles que praticam tal conduta $^{251}$.

\footnotetext{
${ }^{246}$ LARRAURI PIJOAN, Elena. La herencia de la criminología crítica. 2. ed. Madri: Siglo veintiuno de España, 2000. p. 13.

247 A expressão inglesa que dá nome a teoria é traduzida como rotulação social, etiquetagem, teoria interacionista ou da reação social.

${ }^{248}$ BECKER, Howard S. Outsiders: studies in the sociology of deviance. Nova Iorque: The Free Press,1997.

${ }^{249}$ BECKER, Howard S. Outsiders: studies in the sociology of deviance. Nova Iorque: The Free Press, 1997. Por expor as relações de poder que engendram o sistema penal, Zaffaroni acredita que o labelling approach se comporta como uma Criminologia de denúncia. Cf. ZAFFARONI, Eugenio Raúl. Criminología: aproximación desde un margen. Colômbia: Temis, 1993.

${ }^{250}$ CID MOLINÉ, José; LARRAURI PIJOAN, Helena. Teorías Criminológicas: explicación y prevención de la delincuencia. Barcelona: Bosh, 2001.

${ }^{251}$ ANDRADE, Vera Regina Pereira de. Do paradigma etiológico ao paradigma da reação social: mudança e permanência de paradigmas criminológicos na ciência e no sendo comum. Revista Brasileira de Ciências Criminais, São Paulo, v. 4, n.14, p. 276-287, abr.ljun. 1996. p. 280.
} 
O labelling approach coloca em três níveis o problema da definição da criminalidade: a investigação do processo de definição da conduta desviada, a atribuição do status de criminoso e o impacto desta na identidade desviante ${ }^{252}$.

Nessa etapa de sua evolução, a Criminologia, que se ocupava apenas do delito e do delinquente, inclui no seu rol de objetos de estudo também o controle social.

Não se trata mais, a partir daqui, de teorias da criminalidade, mas sim de teorias da criminalização.

A tese interacionista questiona o princípio da igualdade, tendo em vista o reconhecimento da seletividade dos processos que determinam quem é criminoso e o que é crime, bem como o do interesse social e do delito natural, por conta de sua teorização sobre as criminalizações primária e secundária. Os princípios do fim e da prevenção também são colocados em xeque ao se apontar as maléficas consequências da pena, mormente a privação de liberdade, na formação de carreiras criminais, rompendo, assim, o cordão umbilical que ainda ligava as teorias sociológicas do delito com a Criminologia Positivista $^{253}$.

Com a adoção do paradigma da reação social, a Criminologia passa a ser crítica das definições produzidas pelas instâncias componentes do sistema penal, deixando assim de ser um elemento interno, auxiliar desse sistema, e posicionando-se externamente a ele. Torna-se impossível sustentar a continuidade da subordinação da Criminologia ao Direito Penal, tal qual pregava o modelo integrado da ciência penal ${ }^{254}$.

Por ter se erigido enquanto crítica a Criminologia tradicional foi identificada, em seu início, como teoria crítica. Tal denominação é abandonada na década de 1970 com o surgimento de uma nova teoria criminológica assim intitulada.

\footnotetext{
${ }^{252}$ ANDRADE, Vera Regina Pereira de. Do paradigma etiológico ao paradigma da reação social: mudança e permanência de paradigmas criminológicos na ciência e no sendo comum. Revista Brasileira de Ciências Criminais, São Paulo, v. 4, n.14, p. 276-287, abr.ljun. 1996. Tais processos podem ser referenciados como criminalização primária, secundária e terciária, respectivamente, e serão explanados no capitulo seguinte do presente trabalho.

${ }^{253}$ BARATTA, Alessandro. Criminologia e Dogmática Penal. Passado e futuro do modelo integral da Ciência Penal. Revista de Direito Penal, Rio de Janeiro, n. 31, p. 5-37, jan.Ijun. 1981.

${ }^{254}$ BARATTA, Alessandro ¿Tiene futuro la Criminología Crítica? Reflexiones sobre el modelo integrado de las ciencias penales y la interdisciplinariedad externa. Capítulo Criminológico, Maracaibo, v. 23, n. 2, p. 487$501,1995$.
} 


\subsubsection{Teoria Crítica}

Tarefa árdua é a de sintetizar o pensamento dos criminólogos críticos, tendo em vista a dificuldade de identificar ideias homogêneas entre eles.

Pode-se, sim, afirmar que o que todos compartilham é o rechaço às construções teóricas da criminologia tradicional. Nesse sentido relatam Taylor, Walton e Young que

a história de fundo da criminologia do século XX é, em grande parte, a história da desvirtuação empírica das teorias (como as de Marx e Durkheim) que tentavam ocupar-se da sociedade como um todo e, por conseguinte, a história da despolitização dos problemas criminológicos ${ }^{255}$.

Ela se edifica com base no método e nas categorias do marxismo e propõe um compromisso de acabar com as desigualdades econômicas e de poder, sem o que não é possível a solução para o problema do crime. De forma geral, empenha-se numa análise materialista do crime e do sistema de controle social, subordinada à estratégia que liga teoria científica à prática política ${ }^{256}$.

Procura explicar e justificar o delinquente como produto das relações sociais, situálo como vítima do processo de rotulação e castigo que opera a serviço do regime estabelecido e questionar a natureza das leis e valores desse regime ${ }^{257}$. Assim, rechaça a possibilidade da ressocialização como função atribuída à pena ${ }^{258}$.

Por tudo isso é que Criminologia então nascida constitui-se numa atividade política, o que se evidencia na interpretação das condutas contrárias a ordem social, bem como na denúncia das instituições que não realizam democraticamente este controle ${ }^{259}$.

Esse novo modo de encarar a criminalidade surgiu nos anos setenta, quase que simultaneamente nos Estados Unidos e na Inglaterra, irradiando-se, mais tarde para os demais países europeus e para a América Latina ${ }^{260}$.

${ }^{255}$ TAYLOR, Ian; WALTON, Paul; YOUNG, Jack. La Nueva Criminología: contribución a una teoria social de la conducta desviada. Tradução de Adolfo Crosa. Buenos Aires: Amorrortu, 1997. p. 294.

${ }^{256}$ SANTOS, Juarez Cirino dos. A Criminologia Radical. Rio de Janeiro: Forense, 1981.

${ }^{257}$ HIRST, Paul Q. Marx y Engels sobre la ley, el delito y la moralidad. Tradução de Nicolas Grab. In: TAYLOR, Ian; WALTON, Paul; YOUNG, Jock (Dir.). Criminología Crítica. Cerro del Agua, Madri, Bogotá: Siglo veintiuno, 1977. p. 255-287.

${ }^{258}$ Lembre-se que essa ideia já havia sido construída anteriormente pela teoria do labelling approach.

${ }^{259}$ BERGALLI, Roberto. Control y liberación en América Latina. Poder y Control: Revista hispanolatinoamericana de disciplinas sobre el control social, Barcelona, n.1, p. 101-106, 1987.

${ }^{260}$ Nesse sentido, Zaffaroni ensaia elaborar um conceito de Criminologia que se adeque melhor a situação da América Latina, no momento histórico atual: "a criminologia é o saber que nos permite explicar como operam os controles sociais punitivos de nossa margem periférica, que condutas e atitudes promovem, que efeitos provocam e como os encobrir enquanto isso seja necessário ou útil para projetar alternativas às soluções punitivas ou soluções punitivas alternativas menos violentas que as existentes e mais adequadas ao 
No ramo norte-americano, por responsabilidade, principalmente, da escola de Berkeley, a qual também criou a organização Union of Radical Criminologists e a revista Crime and Social Justice. No inglês, pelos esforços de Ian Taylor, Paul Walton e Jack Young, idealizadores da National Deviance Conference.

Foi de grande valia para o despertar desse movimento de reforma a reedição, no ano de 1968, da obra Punição e Estrutura Social, escrita pelos autores Georg Rusche e Otto Kirchheimer ${ }^{261}$, no período entre guerras.

Em seu texto, os autores ressaltam a existência de diversos estudos acerca da relação entre o crime e o meio social, para, em seguida, criticarem o fato de nem as teorias sociológicas, nem as teorias da pena terem se preocupado com a análise mais acurada dos métodos de punição.

Visando a apresentar um estudo dessa natureza, os autores defendem uma estreita vinculação entre a ação dos sistemas penais e o momento econômico vivenciado pela sociedade, inserindo aquele na dinâmica dos sistemas sociais como um todo, e não o considerando mero produto de uma lei específica.

Desta feita, a relação histórica entre o mercado de trabalho e o sistema punitivo é a tese central do trabalho.

Assim, para os autores, a obrigatoriedade do trabalho dos presos nas galés, no século XVI, deveu-se à escassez de trabalhadores livres, os quais se negavam a realizar insalubre tarefa; a repressão à mendicância e vadiagem, contrárias aos valores da ascendente burguesia, determinaram o surgimento das casas de correção no fim do século XVII; o sistema de encarceramento foi impulsionado pelo Mercantilismo e pelo Iluminismo, e assim por diante ${ }^{262}$.

Os já citados criminólogos Taylor, Walton e Young, representantes principais do período inicial da Criminologia crítica, asseveram a necessidade de a nova teoria se ocupar da análise política e da vinculação do homem com a sociedade, negligenciadas pelas formulações precedentes, exaltando, assim, a urgência de uma construção eminentemente sociológica do desvio.

Para tanto, não poupam críticas a todas as teorias criminológicas antecessoras.

progresso social”. Cf. ZAFFARONI, Eugenio Raúl. Criminología: aproximación desde un margen. Colômbia: Temis, 1993. p. 20.

${ }^{261} \mathrm{Na}$ realidade a obra não foi escrita em conjunto pelos dois autores. Rusche encarregou-se da elaboração dos capítulos II e VIII, enquanto que Kirchheimer escreveu os demais.

${ }^{262}$ RUSCHE, Georg; KIRCHHEIMER, Otto. Punição e estrutura social. Tradução de Gizlene Neder. Rio de Janeiro: Freitas Barros, 1999. 
Defendem que não é apenas a Criminologia que está em crise, mas também a própria sociedade. Por isso, exaltam que deve ser buscada uma possibilidade de se resolver, socialmente, suas questões fundamentais ${ }^{263}$.

Essa solução, segundo eles, só pode ser encontrada numa Criminologia normativamente consagrada à abolição das desigualdades da riqueza e do poder e, precipuamente, das desigualdades relativas aos bens e as possibilidades vitais dos indivíduos, sendo que uma ciência criminológica que não obedecer a esses requisitos caminhará, inevitavelmente, ao encontro do correcionalismo e sua concepção patológica do delito $^{264}$.

Destacam, desta feita, os elementos essenciais formais dessa nova Criminologia superadora. São, sinteticamente, a economia política do delito, ou seja, o entendimento da origem do delito em função da situação econômica e política rapidamente cambiante das sociedades industriais; a psicologia social do delito, pela qual se explica que os homens podem eleger, de maneira consciente, a opção pela desviação, como única solução aos problemas que emergem da existência de uma sociedade contraditória; a dinâmica social dos atos, consistente na relação entre a crença e a atitude empiricamente realizada pelo indivíduo; a psicologia social da reação social, que explica a reação imediata do grupo social ao delito, tendo em vista a gama de opções que possuem; a economia política da reação social, consistente na perquirição sobre as origens mediatas da reação social; a influência da reação social sobre a conduta posterior do desviado, levando-se em conta que, numa teoria plenamente social, ele tem sempre consciência das reações que se insurgirão contra ele, baseando-se nessa consciência sua ação futura; por fim, anunciam a necessidade da consideração de todos os elementos formais citados, para que uma teoria seja realmente social ${ }^{265}$.

Os pensamentos aqui demonstrados representam a origem da Criminologia crítica, mostrada no contexto da evolução criminológica que atinge aqui seu ápice.

As vertentes dessa Criminologia, que ainda hoje estão sendo construídas, continuam a ser bastante heterogêneas, existindo em seu seio desde teorias meramente

\footnotetext{
${ }^{263}$ TAYLOR, Ian; WALTON, Paul; YOUNG, Jack. La Nueva Criminología: contribución a una teoria social de la conducta desviada. Tradução de Adolfo Crosa. Buenos Aires: Amorrortu, 1997.

${ }^{264}$ TAYLOR, Ian; WALTON, Paul; YOUNG, Jack. La Nueva Criminología: contribución a una teoria social de la conducta desviada. Tradução de Adolfo Crosa. Buenos Aires: Amorrortu, 1997.

${ }^{265}$ TAYLOR, Ian; WALTON, Paul; YOUNG, Jack. La Nueva Criminología: contribución a una teoria social de la conducta desviada. Tradução de Adolfo Crosa. Buenos Aires: Amorrortu, 1997.
} 
contestatórias do sistema de penas instituído até as mais radicais, defensoras de sua abolição.

Fato é que neste momento da evolução da ciência fica clara a inviabilidade das explicações tradicionais, não críticas, voltarem a dominar a cena criminológica. 


\section{CAPÍTULO 2. TEORIA DO LABELLING APPROACH}

\subsection{CONTEXTO HISTÓRICO-SOCIAL DO NASCIMENTO DA TEORIA}

Acontecimentos de grande relevância marcaram a década de 1960 em todo o mundo, especialmente nos Estados Unidos, país, como já aludido no capítulo anterior, berço da Criminologia sociológica e da teoria do labelling approach ${ }^{266}$.

Diante disso, mister seja realizada uma análise mais acurada da realidade norteamericana no referido período, visando à compreensão do momento social encorajador de avanços em diversas áreas do saber.

Foi justamente no âmbito e em decorrência dos acontecimentos dessa década que surgiram e solidificaram-se movimentos de desconstrução e radicalização no campo social e de algumas ciências humanas e sociais, tal qual a Criminologia, especialmente porque se tornaram evidentes a opressividade do sistema e a necessidade impostergável de combater o status quo.

A crise do Estado de Bem-estar social veio acompanhada da politização da Filosofia social, das Ciências Humanas e, sobretudo, da Criminologia e de mudanças bastante significativas em suas teorizações. Na seara penal e criminológica, esse momento recebeu de Cohen os nomes de impulso desestruturador ou desconstrução dos modelos penais fundamentais e de Zaffaroni a denominação de marcos teóricos fundamentais da deslegitimação do sistema penal ${ }^{267}$.

Para Andrade podem-se verificar duas dimensões distintas nesse movimento: a da crítica historiográfica, sociológica e criminológica do moderno sistema penal e a das políticas criminais alternativas e dos movimentos de reforma. Para a autora, o labelling approach insere-se na primeira dimensão referida, sendo que da crítica sociológica realizada pela teoria resultou o câmbio de paradigma na Criminologia ${ }^{268}$.

\footnotetext{
${ }^{266}$ A despeito dos Estados Unidos serem seu nascedouro, o labelling approach foi divulgado para além dele, na Europa, especialmente na Alemanha e na e Inglaterra.

${ }^{267}$ ANDRADE, Vera Regina Pereira de. A ilusão da segurança jurídica: do controle da violência à violência do controle penal. 2. ed. Porto Alegre: Livraria do Advogado, 2003.

${ }^{268}$ ANDRADE, Vera Regina Pereira de. A ilusão da segurança jurídica: do controle da violência à violência do controle penal. 2. ed. Porto Alegre: Livraria do Advogado, 2003.
} 
Como ocorrências histórico-sociais marcantes, destacam-se, de antemão, a polêmica política externa norte-americana; o nascimento das contraculturas; a conscientização acerca da existência de crimes mais graves do que os tradicionais, tais quais os de colarinho branco e os transnacionais; a desproporcional violência dirigida aos movimentos sociais contestatórios surgidos no período; entre outras ${ }^{269}$.

De suma importância foram ainda as lutas pelo reconhecimento da igualdade de direitos dos negros e das mulheres, as manifestações contrárias à guerra do Vietnã e a proposição de estilos alternativos de vida pelos jovens da época.

A relevância dessas inovações foi tamanha a ponto de ser considerada como "a única invenção revolucionária contemporânea verdadeiramente original”270.

A constatação fática foi a de que um abismo separava a geração de 1960 de suas antecessoras mais próximas. Esta, progressista, autoconfiante, autônoma; aquelas, inseguras, traumatizadas pela guerra e pelas oscilações econômicas.

Assim, os jovens de 1960 iniciaram embates contra o autoritarismo e contra as instituições em que ele mais se fazia presente: a família, as empresas, as escolas e as universidades. Difundiram ainda comportamentos contraculturais como a desobediência civil, a participação em manifestações contra o governo, a defesa aberta ao pacifismo, a queima de convocações do serviço militar, bem como o repúdio à sociedade de consumo $^{271}$, fatores esses que agravaram a crise dos Estados de Bem-estar social, cujo desinteresse pelos grupos excluídos e prejudicialidade a eles tornava-se cada vez mais evidente.

A ruptura de muitos jovens com a velha ordem vigente e seu estilo de vida alternativo encorajaram também novas interações entre grupos sociais distintos, tais como brancos e negros, homens e mulheres, policiais e civis ${ }^{272}$.

Desse modo, os movimentos de reforma iniciados nesse momento caracterizavamse, precipuamente, "pela idade dos jovens manifestantes e por uma nova ética e estética

${ }^{269}$ CASTRO, Lola Aniyar de. Criminologia da reação social. Tradução de Ester Kosovski. Rio de Janeiro: Forense, 1983.

${ }^{270}$ REVEL, Jean-Francois. A revolução imediata. Tradução de Maria Emília Mauhin. Lisboa: Bertrand, 1970. p. 46.

${ }^{271}$ ZAPPA, Regina; SOTO, Ernesto. 1968: eles só queriam mudar o mundo. Rio de Janeiro: Jorge Zahar, 2008.

${ }^{272}$ NEVINS, Allan; COMMAGER, Henry Steele. Breve história dos Estados Unidos. Tradução de Luiz Roberto de Godói Vidal. 7. ed. São Paulo: Alfa-Omega, 1986. 
reativa, na qual entrariam em jogo esquemas religiosos e morais e também de pensamento social, político e até criminológico"273.

Um dos principais agrupamentos de jovens conformado no período foi o dos hippies, grandes representantes do movimento contracultural norte-americano. Fato é que eles defendiam um estilo de vida radicalmente diferente do que vigia em seu país. Pregavam o pacifismo, o respeito à natureza, a alimentação natural, inclusive sem o consumo de carnes, a defesa dos direitos das minorias, a prática do amor livre, a crítica a sociedade de consumo, a assimilação de religiões e filosofias orientais, o tarô, a astrologia e o consumo de drogas.

O uso dos cabelos compridos, uma de suas marcas, tornou-se uma obsessão dos jovens norte-americanos. Enquanto o musical Hair fazia um enorme sucesso na Broadway, uma ampla campanha publicitária era veiculada pelo governo através da reprodução de cartazes com os dizeres "embeleze a América, corte o cabelo",274.

É certo que a postura altamente autoritária, capitalista e consumista dos Estados Unidos permitiu o nascimento da filosofia hippie, avessa a todos esses valores. Também, em decorrência da política externa que adotou, tornou-se alvo de críticas de praticamente toda a sociedade norte-americana, e não apenas dos jovens hippies, situação que se tornou insustentável diante das barbáries cometidas na guerra contra o Vietnã.

A hostilidade norte-americana em relação à China surgiu quando esta despontou como, potencialmente, a mais forte das nações comunistas, pronta inclusive para desbancar a União Soviética.

O Vietnã já tinha seu território bastante destruído no ano de 1964 quando se iniciou a guerra entre este país e os Estados Unidos, já que desde 1946 lutava pelo controle de seu território com a França ${ }^{275}$.

O estopim para a guerra entre o país que vivia do plantio de arroz e a grande potencial mundial, posição na qual já havia se consolidado os Estados Unidos, foi um

${ }^{273}$ ANITUA, Gabriel Ignacio. Histórias dos pensamentos criminológicos. Tradução de Sérgio Lamarão. Rio de Janeiro: Revan, 2008. p. 571.

${ }^{274}$ ZAPPA, Regina; SOTO, Ernesto. 1968: eles só queriam mudar o mundo. Rio de Janeiro: Jorge Zahar, 2008.

${ }^{275}$ No mesmo ano em que declararam guerra ao Vietnã os Estados Unidos apoiaram o golpe contra o Presidente da República brasileira João Goulart, considerado pelo país simpatizante do comunismo. Cf. ZAPPA, Regina; SOTO, Ernesto, 1968: eles só queriam mudar o mundo. Rio de Janeiro: Jorge Zahar, 2008. 
alegado ataque a dois destróieres seus, concretizado por lanchas norte-vietnamitas, investida esta realizada nas águas internacionais do golfo de Tonquim ${ }^{276}$.

Tal evento foi fraudulentamente usado pela Resolução do Golfo de Tonquin, que permitia ao Presidente da República declarar guerra, se autorizado pelo poder Legislativo. Após aprovação unânime pela Câmara e com apenas duas dissonâncias no Senado, Lyndon Johnson determinou o início dos bombardeios a região.

Antes mesmo de seu término, os Estados Unidos já haviam atingido o sudeste da Ásia com o triplo das bombas lançadas durante todo o período da Segunda Guerra Mundial e o efetivo combatente americano no território inimigo alcançara a cifra de quinhentos e cinquenta $\mathrm{mil}^{277}$.

A guerra estendeu-se por longos anos e sua cruenta revoltou os norte-americanos, que protestavam pelo seu término.

Ainda outra manifestação social paradigmática do período foi a luta dos negros pelo reconhecimento e afirmação de seus direitos civis, impulsionada por um acontecimento ocorrido em primeiro de dezembro de 1955, quando, em Montgomery, Alabama, a costureira negra Rosa Parks se negou a ceder seu lugar no ônibus a um homem de pele branca, desrespeitando assim a lei do apartheid racial.

Em decorrência desse fato, em cinco de dezembro do mesmo ano, com a organização da Associação pelo Progresso de Montgomery, iniciou-se na cidade o boicote dos negros aos transportes públicos, negando-se eles a utilizá-los devido à obediência das empresas do setor às leis estaduais e citadinas de segregação racial. Tal protesto contou com o apoio de quase todos os cinquenta mil negros de Montgomery, os quais, por quase um ano, abarrotaram as ruas da cidade ao locomoverem-se, em sua maioria, a pé.

A partir desse evento, Luther King, que havia sido escolhido para presidir a referida Associação, emergiu como um novo modelo de líder - não violento -, o que foi determinante para a faceta pacifista dos movimentos antissegregacionistas procedentes ${ }^{278}$.

${ }^{276}$ ZAPPA, Regina; SOTO, Ernesto. 1968: eles só queriam mudar o mundo. Rio de Janeiro: Jorge Zahar, 2008.

277 NEVINS, Allan; COMMAGER, Henry Steele. Breve história dos Estados Unidos. Tradução de Luiz Roberto de Godói Vidal. 7. ed. São Paulo: Alfa-Omega, 1986.

${ }^{278}$ Luther King, dando início aos trabalhos da Associação pelo Progresso de Montgomery, discursou: "Mas aqui nos reunimos, em especial, devido à situação dos ônibus de Montgomery. Aqui nos reunimos porque estamos determinados a corrigir essa situação, que, definitivamente, não é nova. O problema existe há muitos e muitos anos. Por muito tempo agora, os negros de Montgomery e de tantas outras regiões suportaram a paralisia incapacitante do medo, nos ônibus de nossa comunidade. [...] Nenhuma cruz arderá em chamas nas paradas de ônibus de Montgomery. Nenhum branco será arrancado de sua casa, levado ao longo de uma estrada distante e linchado por não cooperar. Nenhum de nós se erguerá para desafiar a Constituição de nossa 
Fato é que a revolução dos negros, que se iniciara timidamente com a Segunda Guerra Mundial, tomou maiores proporções a partir de três realizações importantes: o início de uma série de decisões da Suprema Corte em defesa de seus direitos de igualdade; a conscientização crescente dos Estados do Norte e a percepção do poder político potencial representado pelo voto dos negros; a tomada da liderança na luta por seus direitos civis ${ }^{279}$.

Após 1960, contudo, a citada luta ganhou mais força e dimensão, já que grande descontinuidade ocorreu na substituição da luta legal, realizada nos Tribunais, pelas massivas manifestações dos próprios negros.

No dia primeiro de fevereiro de 1960 quatro calouros da A\&T, em Greensboro, aos quais houve recusa em servir-lhes a refeição em virtude da cor de suas peles, decidiram, como forma de repúdio ao ato, permanecer no refeitório por todo aquele dia. Daí seguiramse protestos em outras universidades e escolas norte-americanas, sendo que em setembro de 1961 podiam ser identificadas manifestações do tipo em mais de cem cidades do país ${ }^{280}$.

Conforme foi anteriormente mencionado, a luta em favor da igualdade social foi encabeçada, em sua maioria, por organizações pacifistas, tal como a Southern Christian Leadership Conference, também fundada por Luther King. Não obstante, erigiram-se movimentos com atuações mais violentas, a exemplo do Black Power e do Black Panther Party.

Este último grupo foi fundado no ano de 1966, na cidade de Oakland. Sua composição e método de atuação diferiam dos demais que estavam engajados na causa. Era formado por jovens dos guetos e das camadas mais pobres da população que defendiam, somente aos negros, entre outras propostas, o uso de armas, a isenção de impostos, a libertação dos recolhidos ao cárcere e o pagamento de indenizações, por serem vítimas, durante séculos, da exploração branca ${ }^{281}$.

nação. Somente nos reunimos aqui movidos pelo desejo de que o direito prevaleça. Meus amigos, quero que no fundo se saiba que nós íamos para o trabalho com a firme e corajosa determinação de levar a justiça aos ônibus desta cidade”. Cf. KING, Martin Luther. Discurso no primeiro comício da Associação pelo Progresso de Montgomery. In: CARSON, Clayborne; SHEPARD, Kris (Org.). Um apelo à consciência: os melhores discursos de Martin Luther King. Tradução de Sérgio Lopes. Rio de Janeiro: Zahar, 2006. p. 23-24. Importante ainda ressaltar que além do envolvimento de Luther King com os protestos em Montgomery, sua participação foi também fundamental na Marcha sobre Washington, ocorrida em 1957, bem como na concentração em Chicago, em 1966.

${ }^{279}$ NEVINS, Allan; COMMAGER, Henry Steele. Breve história dos Estados Unidos. Tradução de Luiz Roberto de Godói Vidal. 7. ed. São Paulo: Alfa-Omega, 1986. Dentre alguns dos principais líderes negros pode-se destacar Martin Luther King, Philip Randolph, Thurgood Marshall e James Baldwin.

${ }^{280}$ OBERSCHALL, Anthony. Social movements: ideologies, interests and identities. Nova Brunswick: Transaction, 1997

${ }^{281}$ ZAPPA, Regina; SOTO, Ernesto. 1968: eles só queriam mudar o mundo. Rio de Janeiro: Jorge Zahar, 2008. 
A despeito das citadas organizações - excepcionais - embaladas pelo uso da violência, o sucesso e a repercussão das manifestações antissegregacionistas deveu-se, além do apoio popular que amealharam, à postura de Luther King, seu grande líder. Para Revel, ele foi o exemplo completo de um herói carismático. Nasceu da vontade e espontaneidade popular, afastou qualquer rasgo de autoritarismo e culto a sua personalidade dos movimentos que dirigia e conseguiu significativas vitórias ao fazer votar e respeitar inúmeras leis em benefício dos direitos dos negros ${ }^{282}$.

Seus discursos difundiram-se e tocaram todo o mundo, sendo o objetivo de sua oratória

forjar um novo estado de justiça e misericórdia, por meio do poder da verdade e da não-violência - verdade que buscava unir homens e mulheres, reconhecidos como irmãos e irmãs. A verdade do amor e da misericórdia que acreditava que os conflitos do mundo se reconciliariam no poder do espírito humano ${ }^{283}$.

Sua base filosófica, evidenciada em todas as suas ações em prol do movimento negro, era a doutrina de resistência não violenta e pacifista de Gândi, característica da maioria das manifestações geridas em $1960^{284}$.

Entretanto, em quatro de abril de 1968 Luther King foi assassinado em Memphis, Tenesse, ao levar um tiro enquanto estava na varanda de um hotel, o que deu início a protestos em todo o país. O que se verificou foi que esse ato "não visava apenas suprimir um orador e um animador antirracista, mas toda uma concepção política"285.

\footnotetext{
${ }^{282}$ REVEL, Jean-Francois. A revolução imediata. Tradução de Maria Emília Mauhin. Lisboa: Bertrand, 1970. 283 YOUNG, Andrew. Introdução. In: CARSON, Clayborne; SHEPARD, Kris (Org.). Um apelo à consciência: os melhores discursos de Martin Luther King. Tradução de Sérgio Lopes. Rio de Janeiro: Zahar, 2006. p. 13-14.

${ }^{284}$ LINK, Arthur S. História moderna dos Estados Unidos. Tradução de Waltensir Dutra Álvaro Cabral e Fernando de Castro Ferro. Rio de Janeiro: Zahar, 1965.

${ }^{285}$ REVEL, Jean-Francois. A revolução imediata. Tradução de Maria Emília Mauhin. Lisboa: Bertrand, 1970. p. 174. No dia 2 de abril de 1968, um dia antes de sua morte, Luther King não se sentia bem e falava em tirar alguns dias de folga para submeter-se a exames. Em razão disso, decidiu não realizar o discurso que faria naquele dia, pedindo para Ralph Abernathy fazê-lo em seu lugar. Ocorre que ao ser avisado da multidão que o esperava na Igreja - cerca de onze mil pessoas - dirigiu-se ao local e, comovido com a bela introdução feita por seu amigo, decidiu proferir aquele que seria seu último discurso. Entre suas palavras professou: "Bem, não sei o que acontecerá agora. Dias difíceis virão. Mas não me importo. Pois eu estive no topo da montanha. E não me importo. Como qualquer pessoa, gostaria de viver uma vida longa. A longevidade tem o seu lugar. Mas não me preocupo com isso agora. Apenas desejo obedecer aos desígnios de Deus. E Ele me levou ao topo da montanha, olhei ao redor e contemplei a Terra Prometida. Posso não alcançá-la, mas quero que saibam, que nós, como povo, chegaremos à Terra Prometida. Estou tão feliz; não me preocupo com nada; não temo homem algum. Meus olhos viram a glória da presença do Senhor”. Cf. KING, Martin Luther. Eu estive no topo da montanha. In: CARSON, Clayborne; SHEPARD, Kris (Org.). Um apelo à consciência: os melhores discursos de Martin Luther King. Tradução de Sérgio Lopes. Rio de Janeiro: Zahar, 2006._p. 171.
} 
Ainda de grande relevância foi o surgimento do movimento feminista contemporâneo, na segunda metade da década de $1960^{286}$. Pode-se considerar, na realidade, a existência de duas vertentes do feminismo desse período: uma postuladora da igualdade das mulheres e outra de sua diferença.

A primeira, defendida nos Estados Unidos, reflete o anseio das mulheres pela igualdade em relação aos homens, tendo em vista a opressão masculina ao gênero oposto. Já a segunda, majoritária na França, pretende o reconhecimento das diferenças entre os sexos e alerta para a necessidade de dar visibilidade à experiência feminina, historicamente negligenciada $^{287}$.

Ressalvadas as mencionadas diferenças, o que o movimento feminista busca é a superação das relações conflituosas entre homens e mulheres, recusando-se estas a assumir qualquer estigma de inferioridade ${ }^{288}$.

O que se pode destacar dos acontecimentos descritos é que eles geraram novas formas de conflito social, o que exigia também da Criminologia formas de interpretação e ação diferenciadas.

Não podia mais ser admitida uma Criminologia condescendente com tais violações e discriminações sociais, mantenedora, pois, do status quo e a serviço do poder estabelecido. Algo tinha que ser mudado, até porque a sociedade já havia se atentado para opressividade do sistema social - mormente o penal -, que autorizava a exacerbada punição da criminalidade tradicional em cotejo com a maior tolerância diante da criminalidade "dos poderosos".

Também como efeito dessa percepção diversas revoltas eclodiram nas prisões da época, tais quais as ocorridas em San Quentim, Les Tombs, Tolsom, Soledad e Attica, as quais contribuíram para que a população se sensibilizasse com a brutalidade predominante no cárcere, onde se recolhiam, especialmente, negros e pobres.

Entre as rebeliões citadas, uma das mais significativas foi a de Attica, em Nova Iorque, na qual trinta e três reclusos e dez guardas foram mortos.

\footnotetext{
${ }^{286}$ Esse movimento é também denominado de segunda fase do feminismo, sendo a primeira representada pela luta das mulheres em busca da igualdade de direitos políticos, civis e educativos ocorrida no seio da Revolução Francesa.

287 NARVAZ, Martha Giudice; KOLLER, Sílvia Helena. Metodologias feministas e estudos de gênero: articulando pesquisa, clínica e política. Disponível em < http://www.scielo.br/pdf/pe/v11n3/v11n3a20.pdf > Acesso em 29 out. 2009.

${ }^{288}$ Destaque-se que esta segunda geração do movimento feminista caracteriza-se pela liderança de mulheres intelectuais, consequência das maiores oportunidades sociais, políticas e educativas que estavam ao alcance das mulheres após a primeira fase do feminismo.
} 
O labelling approach surgiu, pois, nesse contexto de crítica à mantença das desigualdades, em que se evidenciou que uma mudança de postura não podia mais ser adiada.

\subsection{BASES INTERDISCIPLINARES PROPULSORAS}

O interacionismo simbólico e a etnometodologia exerceram grande influência na Sociologia do desvio e do controle social, sendo pilares conceituais fundamentais sobre os quais se erigiu o labelling approach.

Numa primeira aproximação ao tema pode-se evidenciar que ambos coadunam do mesmo entendimento acerca do processo social. Para eles a realidade social não é uma objetividade estanque, uma vez que nela existem constantes processos de interação entre os sujeitos, que saem dali modificados ${ }^{289}$.

A grande diferença entre ele refere-se à natureza da realidade social em relação com a conduta humana. Para os interacionistas existe uma realidade objetiva à qual as pessoas colocam significados, enquanto para os etnometodólogos a citada realidade não existe, tendo as pessoas a construído por inteiro ${ }^{290}$.

Além disso, o interacionismo simbólico dispensa maior atenção aos processos de definição, enquanto a etnometodologia, aos atores do sistema penal e ao método utilizado pelas pessoas para se chegar a uma definição ${ }^{291}$.

Tais semelhanças e diferenças, contudo, poderão ser melhores compreendidas nos dois itens subsequentes, em que serão apresentadas essas duas perspectivas.

\subsubsection{Interacionismo simbólico}

Não há consenso acerca da origem do pensamento interacionista, sendo também difícil estabelecer uma conceituação única de sua significação. Atribui-se essa dificuldade

\footnotetext{
${ }^{289}$ ANDRADE, Vera Regina Pereira de. Do paradigma etiológico ao paradigma da reação social: mudança e permanência de paradigmas criminológicos na ciência e no sendo comum. Revista Brasileira de Ciências Criminais, São Paulo, v. 4, n.14, p. 276-287, abr.ljun. 1996.

${ }^{290}$ EINSTADTER, Werner J.; HENRY, Stuart. Criminological theory: an analysis of its underlying assumptions. 2. ed. Nova Iorque: Rowman \& Littlefield, 2006.

${ }^{291}$ GROSNER, Marina Quezado. A seletividade do sistema penal na jurisprudência do Superior Tribunal de Justiça: o trancamento da criminalização secundária por decisões em habeas corpus. São Paulo: IBCCRIM, 2008 .
} 
ao fato de diversos autores terem se debruçado sobre o tema, em momentos e locais distintos, adotando ainda diferentes abordagens teóricas ${ }^{292}$.

Assim, visando a expor suas proposições de maneira mais clara e de modo a atender ao propósito precípuo deste excerto, que é o de demonstrar a influência da perspectiva interacionista sobre a construção do labelling approach, este item será baseado preponderantemente na obra de Mead, cujo pensamento, por sua extremada importância, não deixou de ser observado em nenhuma análise que se propusesse interacionista ${ }^{293}$.

Inicialmente se pode evidenciar, de maneira perfunctória, que o interacionismo simbólico representa um ramo da Sociologia e da Psicologia Social que se concentra nos processos de interação ${ }^{294}$.

Blumer foi quem primeiro usou da nomenclatura citada, no ano de 1937. Contudo, em momento mais recente, alegou que quando a utilizou o fez expondo uma posição de Mead, cuja obra interpretou ${ }^{295}$.

A despeito de ser considerado um dos grandes precursores do interacionismo simbólico, não há nas obras de Mead nenhuma referência à mencionada expressão. Essa designação foi dada a sua teoria apenas após sua morte, baseando-se nas proposições por ele desenvolvidas.

A principal contribuição de Mead para a Sociologia do Conhecimento foi a elaboração de uma Psicologia Social mais adequada para a compreensão da relação funcional existente entre sociedade e indivíduo ${ }^{296}$.

Explica o filósofo que sua Psicologia condutista se propõe a elaborar técnicas que permitam entender as experiências que qualquer indivíduo possa ter, nos termos mais gerais possíveis, utilizando-se do método de averiguação sobre as condições em que ocorre dita experiência para todos.

\footnotetext{
${ }^{292}$ Fala-se na existência de duas vertentes do interacionismo simbólico: uma derivada do pensamento de Mead e outra da Sociologia da Escola de Chicago, representada especialmente por Thomas e Park.

${ }^{293}$ Convém mencionar que a própria Sociedade para o estudo do interacionismo simbólico (SSSI) deriva seus estudos das proposições de Mead. Cf. SOCIETY FOR THE STUDY OF SYMBOLIC INTERACTION. Disponível em <www.espach.salford.ac.uk/sssi>. Acesso em 8 jul. 2009. São ainda autores interacionistas de destaque Blumer, Dewey e Cooley.

${ }^{294}$ SHECAIRA, Sérgio Salomão. Criminologia. 2. ed. rev. São Paulo: Revista dos Tribunais, 2008.

${ }^{295}$ NUNES, Jordão Horta. Interacionismo simbólico e dramaturgia: a sociologia de Goffman. São Paulo: Humanitas, 2005.

${ }^{296}$ COSER, Lewis A.; ROSENBERG, Bernard. American antecedents of the sociology of knowledge. In: COSER, Lewis A.; ROSENBERG, Bernard (Ed.). Social theory: a book of readings. Nova Iorque: Macmillan, 1957.
} 
Ressalta ainda que se trata de uma perspectiva de controle, de uma Psicologia que avança nos campos em que se pode obter fiscalização, no intuito de dominar por meio do conhecimento obtido ${ }^{297}$.

De acordo com a perspectiva interacionista, o indivíduo é construído, moldado, de acordo com suas interações com o meio em que habita e com os demais sujeitos.

O organismo e o meio, portanto, são mutuamente dependentes em sua existência, determinando-se um ao outro. Por isso, acredita-se que o processo vital só pode ser compreendido em termos de suas interrelações ${ }^{298}$.

É através do sentido que os atores sociais atribuem aos objetos, aos fenômenos, aos símbolos, que eles constroem o mundo social.

Entretanto, essa concepção da sociedade como uma construção social não permite que ela seja considerada como mera ficção.

Explica-se. Mead acredita que há um mundo externo objetivo que independente do pensador individual que o considera. Em contrapartida, os objetos que compõem esse mundo possuem certas características, as quais só existem devido às suas relações com a experiência do indivíduo, com seu espírito, como por exemplo, as cores. Afirma o autor que elas são inerentes aos objetos apenas em relação ao indivíduo que os percebe, fora o que não há que se falar na sua existência ${ }^{299}$.

No tocante às interações entre os indivíduos, Mead as estudou sob uma ótica diversa da então predominante. Para ele, o ato de alguém não pode ser entendido em si mesmo, isoladamente, uma vez que está intrinsecamente relacionado a um todo dinâmico, que é a sociedade. Assim, propôs-se a explicar a conduta do sujeito nos termos da do grupo social, cuja atitude considerava preexistente à dos seres individuais que o compõem ${ }^{300}$.

Sociedade e indivíduo deixam, pois, de ser vistos como realidades estanques e imutáveis, já que em constante interação e transformação.

Vale dizer que tais mutações são permitidas pela comunicação, processo sem o qual não existe a pessoa nem a sociedade.

\footnotetext{
${ }^{297}$ MEAD, George H. Espíritu, Persona y Sociedad. Tradução de Florial Mazía. Buenos Aires: Paidos, 1953. $\mathrm{O}$ autor não faz nenhuma crítica a possibilidade de controle através da Psicologia moderna. Ele simplesmente aponta esta sua faceta.

${ }^{298}$ MEAD, George H. Espíritu, Persona y Sociedad. Tradução de Florial Mazía. Buenos Aires: Paidos, 1953. ${ }^{299}$ MEAD, George H. Espíritu, Persona y Sociedad. Tradução de Florial Mazía. Buenos Aires: Paidos, 1953. ${ }^{300}$ MEAD, George H. Espíritu, Persona y Sociedad. Tradução de Florial Mazía. Buenos Aires: Paidos, 1953.
} 
Mead pensa nos gestos em termos sociais e neles encontra os rastros do desenvolvimento de uma verdadeira comunicação de linguagem ${ }^{301}$.

Para o filósofo os gestos são o começo dos atos sociais, identificando-se seu surgimento antes mesmo da ideia, uma vez que prescindem do pensamento. Entretanto, quando por detrás de um gesto existe uma ideia, uma significação, ele se torna um símbolo significante. Este, por sua vez, quando existente, tem o condão de despertar as mesmas reações, implicitamente, no que o realiza, e explicitamente, no que o recebe $\mathrm{e}^{302}$.

Ainda de acordo com seu pensamento, são os símbolos significantes, a intervenção da linguagem o mais importante deles, que permitem a transformação do indivíduo biológico em pessoa com espírito ${ }^{303}$.

Apenas por meio da comunicação, dos símbolos significantes, é que nasce o espírito. Ou seja, é ele um fenômeno social que surge apenas quando o organismo está em condições de atribuir significados a outros e a ele mesmo, razão pela qual se pode afirmar que o desenvolvimento da linguagem, mormente do símbolo significante, tornou possível a incorporação da situação social externa a conduta do indivíduo ${ }^{304}$.

Esse processo de relacionar o próprio organismo com o dos outros, nas interações que se realizam, constitui a pessoa ${ }^{305}$. Também a sociedade só surge graças à possibilidade da internalização dessa atitude social nas relações de toda a comunidade.

Note-se, então, que a interação entre os indivíduos que compõem a sociedade só é possível mediante a existência de símbolos comuns para fenômenos e situações determinadas, os quais colocam os sujeitos em condições de compreender-se e definir-se mutuamente ${ }^{306}$.

\footnotetext{
${ }^{301}$ MORRIS, Charles W. George H. Mead como psicólogo y filósofo social. In: MEAD, George H. Espíritu, Persona y Sociedad. Buenos Aires: Paidos, 1953.

${ }^{302}$ MEAD, George H. Espíritu, Persona y Sociedad. Tradução de Florial Mazía. Buenos Aires: Paidos, 1953.

${ }^{303}$ MORRIS, Charles W. George H. Mead como psicólogo y filósofo social. In: MEAD, George H. Espíritu, Persona y Sociedad. Buenos Aires: Paidos, 1953. Cooley, cuja teorização interacionista aproxima-se bastante da de Mead, numa inversão terminológica, denomina complexo mental-social (mental-social complex) o que este chama de espírito, por entender tratar-se de expressão mais elucidativa. Cf. COOLEY, Charles Horton. Sociological theory and social research. Nova Iorque: Henry Holt, 1930.

${ }^{304}$ MEAD, George H. Espíritu, Persona y Sociedad. Tradução de Florial Mazía. Buenos Aires: Paidos, 1953.

${ }^{305}$ Mead defende uma teoria social da pessoa em oposição à teoria social do contrato. Para esta, a formação da sociedade decorre de uma necessidade dos indivíduos, que, por isso, decidem criá-la. Aquela, em contrapartida, acredita que a pessoa não pode preceder a sociedade, uma vez que o sujeito torna-se pessoa apenas através de sua comunicação significante com os outros. Nesse diapasão, se a pessoa só surge com as atividades sociais, não pode ser anterior a formação da própria sociedade.

${ }^{306}$ RÜTHER, Werner. La criminalidad (o el "delincuente") a traves de las definiciones sociales (o etiquetamiento). Doctrina Penal: Teoría y Práctica en las Ciencias Penales, Buenos Aires, v. 1, n. 1-4, p. 749-764, 1978.
} 
Nesse contexto, são características de toda a interação a atribuição de papéis, de rótulos, ou, em geral, a tipificação de pessoas ${ }^{307}$.

Importante contribuição do interacionismo simbólico foi também seu entendimento acerca da internalização das normas sociais, que Mead expressou por meio da explanação do "eu" e do "mim", elementos conformadores da personalidade ${ }^{308}$.

O “mim” evidencia-se na adoção, pelo indivíduo, das atitudes organizadas dos outros, representando, assim, os valores da sociedade que o sujeito adquire, enquanto afetam sua própria conduta. Trata-se da classe de experiência que o grupo social faz possível.

Em observância ao "mim", o sujeito, durante uma partida de futebol, por exemplo, lança a bola a algum membro da equipe, atendendo a exigência que apresentam os outros companheiros do time.

Por sua vez, o "eu" é a resposta do sujeito às atitudes que os outros têm em relação a ele. É uma reação incerta, que pode proporcionar uma sensação de liberdade, de iniciativa, representando uma reconstrução da sociedade e do "mim" que a ela pertence. É por meio dele que se evidencia a capacidade do indivíduo em modificar seu entorno, podendo-se constatar ser ele determinante de seu meio. ${ }^{309}$.

Portanto, o "mim" representa uma organização definida da comunidade, presente nas atitudes dos que a compõe, e que provoca uma reação, exercida pelo "eu”, a qual pode ou não ser condizente com o "mim" internalizado.

Mister que se evidencie que a despeito de as pessoas serem constituídas por processos iguais, elas têm sua individualidade peculiar, já que cada um interpreta a pauta das relações sociais sob um prisma único e à medida em que se desenvolve a comunidade, mais espaço há para a manifestações dessas individualidades. Em outros termos, "as sociedades crescem em complexidade de organização só por meio da consecução

307 RÜTHER, Werner. La criminalidad (o el "delincuente") a traves de las definiciones sociales (o etiquetamiento). Doctrina Penal: Teoría y Práctica en las Ciencias Penales, Buenos Aires, v. 1, n. 1-4, p. 749-764, 1978.

${ }^{308}$ MEAD, George H. Espíritu, Persona y Sociedad. Tradução de Florial Mazía. Buenos Aires: Paidos, 1953. As expressões traduzidas no presente trabalho como "eu" e "mim" são referidas na versão em espanhol da obra de Mead por "yo" e "mí".

${ }^{309}$ A atitude inovadora praticada pode ser tanto de degradação quanto de conformação com os valores mais elevados. 
progressiva de proporções cada vez maiores de diferenciação funcional, de comportamento, entre os indivíduos que as constituem"310.

Isso posto, esclarece-se o processo por meio do qual ocorre a internalização dos regramentos da sociedade.

Destaca-se que ainda por meio das noções do "eu" e do "mim" pode-se elucidar o controle social. Nos dizeres de Mead:

o controle social é a expressão do 'mim' em comparação com a expressão do 'eu'. Estabelece os limites, proporciona a determinação que permite ao 'eu', por assim dizê-lo, empregar o 'mim' como meio para levar a cabo a empresa em que todos estão interessados ${ }^{311}$.

O interacionismo simbólico, para chegar às suas proposições acerca do entrelaçamento entre sociedade e sujeitos individuais, utilizou-se da pesquisa qualitativa e crítica, mais condizente com sua proposta teórica, rechaçando, por outro lado, qualquer espécie de aferição quantitativa.

Encarava, ademais, como objeto essencial da pesquisa sociológica a concepção que os atores têm acerca do mundo social e dos fenômenos ali representados.

A metodologia que utilizou e a nova compreensão que apresentou acerca das relações sociais fizeram com que seus ensinamentos fossem tomados emprestados por diversas áreas do saber.

Nesse sentido, já previa Morris, no ano de 1953, que as ideias concebidas por Mead "têm todos os indícios de possuir em si o poder de enriquecer os conceitos das ciências sociais, de surgir novas vias de investigação empírica e de abrir novos horizontes para a interpretação filosófica"312.

A década de 1960 na história do interacionismo simbólico foi marcada pela efervescência acadêmica e política provocada pela perspectiva nos Estados Unidos, sendo o momento em que ocorreu a incorporação de novos desenvolvimentos teóricos pelos pesquisadores interacionistas, dando-se origem às teorias do conflito, à fenomenologia, à etnometodologia e ao labelling approach $^{313}$. Este, por sua vez, leva ao extremo a

${ }^{310}$ MEAD, George H. Espíritu, Persona y Sociedad. Tradução de Florial Mazía. Buenos Aires: Paidos, 1953. p. 321.

${ }^{311}$ MEAD, George H. Espíritu, Persona y Sociedad. Tradução de Florial Mazía. Buenos Aires: Paidos, 1953. p. 234

${ }^{312}$ MORRIS, Charles W. George H. Mead como psicólogo y filósofo social. In: MEAD, George H. Espiritu, Persona y Sociedad. Buenos Aires: Paidos, 1953. p. 47-48.

${ }^{313}$ NUNES, Jordão Horta. Interacionismo simbólico e dramaturgia: a sociologia de Goffman. São Paulo: Humanitas, 2005. 
orientação interacionista segundo a qual o mundo social não é dado, mas sim construído dia a dia, assim como o são os homens e suas tipificações ${ }^{314}$.

\subsubsection{Etnometodologia}

O termo etnometodologia foi cunhado em 1967, por Garfinkel, em sua obra Studies of Ethnomethodology, considerada a fundadora da matéria ${ }^{315}$. Em sua definição da expressão relata que ela se refere à investigação das propriedades racionais das expressões indicativas e das ações como realizações contingentes das práticas da vida cotidiana ${ }^{316}$.

Em outros termos, a etnometodologia ocupa-se do estudo empírico das atividades cotidianas, triviais ou eruditas, dando a elas a mesma atenção que recebem os eventos extraordinários, visando ainda à compreensão de como os indivíduos, em conjunto, apreendem e definem as situações e fenômenos sociais ${ }^{317}$.

Na definição de Cicourel $^{318}$,

a etnometodologia interessa-se no processo pelo qual se constroem as regras que devem cobrir as situações de interação social; ela interessa-se igualmente à análise da avaliação da aplicação dessas regras dentro de circunstâncias particulares. A etnometodologia coloca em evidência a atividade interpretativa necessária para reconhecer que existe uma regra abstrata correspondente a uma situação particular ${ }^{319}$.

Sua importância teórica e epistemológica deve-se ao fato de ter representado uma ruptura em relação à Sociologia tradicional, por meio da ampliação do pensamento social, constituindo, então, uma nova perspectiva de pesquisa e uma nova postura intelectual ${ }^{320}$.

\footnotetext{
${ }^{314}$ Note-se que a assunção, pelo labbeling approach, da concepção interacionista de acordo com a qual pessoas e sociedade são resultados de processos dinâmicos, faz da citada teoria criminológica antideterminista, a despeito de algumas críticas dessa natureza. Cf. DIAS, Jorge de Figueiredo; ANDRADE, Manuel da Costa. Criminologia: o homem delinqüente e a sociedade criminógena. 2 reimp. Coimbra: Coimbra Editora, 1997.

${ }^{315}$ Garfinkel, representante da Sociologia norte-americana, na confecção de sua obra, sofreu influências de seu professor Parsons, Schütz e do interacionismo simbólico.

${ }^{316}$ GARFINKEL, Harold. Studies in Ethnomethodology. Nova Jersey: Prentice-Hall, 1967.

317 A etnometodologia é considerada uma versão da fenomenologia sociológica. Esta é uma Sociologia baseada em considerações fenomenológicas, cujo principal pensador foi Schutz, inspirado, principalmente, nas obras de Husserl e Weber. Trata-se de um pensamento que adota como ponto de partida o indivíduo e não os sistemas sociais ou instituições que ele produz, característica que foi também incorporada pela etnometodologia. Cf. SCHUTZ, Alfred. Fenomenologia e relações sociais. Tradução de Ângela Melin. In: Wagner, Helmut R. (Org). Fenomenologia e relações sociais. Rio de Janeiro: Zahar, 1979.

${ }^{318}$ Cicourel foi o primeiro discípulo importante de Garfinkel.

${ }^{319}$ CICOUREL, Aaron V. La sociologie cognitive. Tradução de Jeffrey e Martine Olson. Paris: Presses Universitaires de France, 1979. p. 134-135.

${ }^{320}$ COULON, Alain. Etnometodologia. Tradução de Ephraim Ferreira Alves. Petrópolis: Vozes, 1995.
} 
Por conta de seu viés de estudo é que se pode constatar sua crença na ineficiência dos métodos até então utilizados pela Sociologia para a análise da vida cotidiana, em que consistia uma de suas principais críticas ao conhecimento sociológico dominante.

As pesquisas sociológicas anteriores, sob a perspectiva etnometodológica, não poderiam mais ser aceitas acriticamente, como representações das realidades perquiridas por um pesquisador neutro. $\mathrm{O}$ novo enfoque

\begin{abstract}
concentra-se no como são exercitadas as interações em certo contexto social, além de olhar para a tendência manifestada pelo próprio pesquisador social diante um certo campo de interações, pois é também pertinente a maneira como os relatórios ou as descrições de acontecimentos são desenvolvidos e $\operatorname{apresentados}^{321}$.
\end{abstract}

Assim, pregava a valorização dos métodos qualitativos de pesquisa, tal como observação participante, a introspecção simpatética e o relato de histórias de vida.

A despeito de a etnometodologia ter se desenvolvido nos departamentos de Sociologia das universidades e nas organizações nacionais e internacionais da matéria, destaca-se seu caráter antissociológico. ${ }^{322}$.

Ao contrário do que pregavam Durkheim e Merton, principais expoentes da Sociologia tradicional e cujas crenças numa realidade objetiva eram incontestes, Garfinkel propôs que as ações fossem compreendidas a partir da perspectiva de seu executor, ou seja, de sua definição sobre $\mathrm{o}$ ato, de suas explicações para ele, prescindindo-se da categorização destas como certas ou erradas.

Desse modo, o autor pretendeu deslocar seu foco de atenção para a maneira como a realidade era construída, suspendendo, assim, a crença em sua objetividade ${ }^{323}$. Defendia que o contexto era construído com base em ações singulares e que essas mesmas ações isoladas, numa relação de reciprocidade, é que o determinavam.

Portanto, para a etnometodologia, sendo a realidade social produto de uma construção social das individualidades, não pode ser ela objetivamente caracterizada ou analisada.

No tocante à interpretação da linguagem, adotou uma postura de renúncia à literalidade, baseada na consideração de que as expressões deveriam ser analisadas dentro do contexto no qual estavam inseridas, já que suas significações dependiam dele. Em

\footnotetext{
${ }^{321}$ VELO, Joe Tennyson. Postura criminológica: entre a etnometodologia e o mito de Hermes. Ciências Penais. Revista da Associação Brasileira de Professores de Ciências Penais, São Paulo, v. 2, p. 114-129, jan./jun. 2005. p. 119.

${ }^{322}$ COULON, Alain. Etnometodologia. Tradução de Ephraim Ferreira Alves. Petrópolis: Vozes, 1995.

${ }^{323}$ Trata-se da adoção, por Garfinkel, da atitude fenomenológica postulada por Husserl.
} 
outras palavras, "o etnometodólogo interessa-se nas capacidades de interpretação que supõem a interação inevitável entre competência e performance",324.

Importante mencionar que mesmo as ações são consideradas precipuamente como resultados de regras interpretativas próprias à comunicação ${ }^{325}$.

Nesse sentido são as conclusões de Cicourel em sua obra The social organization of Juvenile Justice. Nela o autor apresenta um estudo que desenvolveu por quatro anos acerca da delinquência juvenil, no qual constatou ser ela uma construção social, em que os agentes envolvidos da persecução estabelecem classificações sociais próprias que designam e permitem reconhecer as categorias de desvio e de conformidade. Mostra, então, como é administrada e negociada a instrução judiciária, na dependência das interpretações dos atos feitas pelos juízes, delegados, educadores ${ }^{326}$.

A atribuição, pois, de um papel, de um status ou da qualidade de apropriada a uma conduta deriva de um procedimento interpretativo que dirige a interação, e não de sua natureza ínsita ${ }^{327}$.

Assim, ao postular que os fatos sociais são construídos a partir do sujeito e não do objeto, forneceu relevante contribuição na tentativa de dessensibilização dos estigmas, defendendo que os acontecimentos decorrem do trabalho intelectual dos sujeitos ao julgarem os acontecimentos sociais ${ }^{328}$.

Ainda no que se refere à interpretação dos indivíduos, Garfinkel criticou o que denominou como cerimônias de degradação: atos que rebaixam o sujeito e autorizam sua identificação ao público como alguém que está abaixo na pirâmide social .

Das ideias acima expostas é que a teoria da rotulação social derivou, respectivamente, suas proposições de crença nas explicações do acusado; o repúdio à existência de um "mundo comum" e a aceitação do desvio como uma construção social; o rechaço as estatísticas por elas serem, na realidade, representações da reação penal, e não dos atos concretamente cometidos.

\footnotetext{
${ }^{324}$ CICOUREL, Aaron V. La sociologie cognitive. Tradução de Jeffrey e Martine Olson. Paris: Presses Universitaires de France, 1979. p. 134.

${ }^{325}$ LIMA, Rita de Cássia Pereira. Sociologia do desvio e interacionismo. Tempo Social. Revista de Sociologia da USP, São Paulo, v. 13, n. 1, p. 185-201, mai. 2001.

${ }^{326}$ COULON, Alain. Etnometodologia. Tradução de Ephraim Ferreira Alves. Petrópolis: Vozes, 1995.

${ }^{327}$ CICOUREL, Aaron V. La sociologie cognitive. Tradução de Jeffrey e Martine Olson. Paris: Presses Universitaires de France, 1979.

${ }^{328}$ VELO, Joe Tennyson. Postura criminológica: entre a etnometodologia e o mito de Hermes. Ciências Penais. Revista da Associação Brasileira de Professores de Ciências Penais, São Paulo, v. 2, p. 114-129, jan./jun. 2005.
} 
Fato é que se passa a defender que

o comportamento desviante esgota-se no quadro das significações assumidas pelos participantes, devendo suspender-se todo o juízo sobre a realidade das normas ou da própria estrutura social. Em nome da redução eidética, o crime é visto como uma construção social, realizada na interação entre o desviante e as agencias de controlo, que a etnometodologia estuda como 'organizações': polícia, tribunal, prisão, hospital psiquiátrico, etc. O que equivale levar até os extremos as, pois, ideias de relativismo e a-historicidade do crime ${ }^{329}$.

\subsection{PROPOSTA DE INVESTIGAÇÃO CRIMINOLÓGICA}

Pode-se considerar que a nascente Criminologia do labelling approach, produto das mudanças sociais e científicas relatadas, destaca-se pela natureza nova das questões formuladas, cuja ênfase é o sistema de controle, pela ruptura metodológica e epistemológica com a Criminologia tradicional, pela substituição de um modelo estático e descontínuo de abordagem do comportamento humano para outro dinâmico e contínuo, pelo repúdio aos métodos anteriormente utilizados, bem como pelo pluralismo cultural ${ }^{330}$.

Mudando o enfoque dos estudos criminológicos predecessores a teoria incluiu na investigação do delito a análise não apenas dos acusados, mas também dos acusadores, denunciando a relação de poder que permite que alguns fiquem nesta confortável posição de eleger as condutas que devem ser reprovadas por todo o grupo social ${ }^{331}$.

Pela primeira vez, na seara criminológica - por força das influências do interacionismo simbólico e da etnometodologia - a ação humana é considerada como parte de um processo que se desenvolve ao longo do tempo, por meio da interação entre os indivíduos. Em outros termos, a pessoa passa a ser considerada coprodutora de um processo dinâmico de interação, o qual forma seu mundo social ${ }^{332}$.

É dos mencionados estudos que o labelling approach tomou emprestado o entendimento de que a realidade social não pode ser apreendida apenas desde uma

\footnotetext{
${ }^{329}$ DIAS, Jorge de Figueiredo; ANDRADE, Manuel da Costa. Criminologia: o homem delinqüente e a sociedade criminógena. 2 reimp. Coimbra: Coimbra Editora, 1997. p. 55.

330 DIAS, Jorge de Figueiredo; ANDRADE, Manuel da Costa. Criminologia: o homem delinqüente e a sociedade criminógena. 2 reimp. Coimbra: Coimbra Editora, 1997.

331 "Teorias interacionistas do desvio, assim como as teorias interacionistas em geral, prestam atenção em como os autores sociais definem um ao outro e seus ambientes. Eles prestam particular atenção as diferenças no poder de definir; no modo como um grupo obtêm e usa o poder para definir como outros grupos serão considerados, entendidos e julgados". Cf. BECKER, Howard S. Outsiders: studies in the sociology of deviance. Nova Iorque: The Free Press, 1997. p. 204.

332 EINSTADTER, Werner J.; HENRY, Stuart. Criminological theory: an analysis of its underlying assumptions. 2. ed. Nova Iorque: Rowman \& Littlefield, 2006. p. 205.
} 
perspectiva exterior, já que depende das interpretações e definições dos sujeitos que nela atuam.

Sendo assim, concentrou sua atenção nos processos sociais que determinam a escolha de alguns comportamentos como ilegais, transformando seu executor em criminoso. Portanto, focou seus estudos nos processos de criminalização, decorrentes do exercício do controle social, e de suas consequências maléficas, o que foi uma de suas principais inovações.

Importante destacar que entre os teóricos do labelling approach há criminólogos influenciados mais fortemente pela perspectiva interacionista e outros pela etnometodólogica, as quais, mister que se ressalte, não são excludentes.

Uma Criminologia mais comprometida com o interacionismo simbólico pode ser denominada de extrovertida. Ela identifica as causas e os fins essencialmente no exterior nas estruturas sociais - e seu trabalho é de explicar o fenômeno reitor das causas e efeitos. Seus principais autores são Lemert e Becker.

Uma Criminologia introvertida, por sua vez, vinculada à etnometodologia, detém-se na investigação dos sujeitos ao em vez das estruturas sociais, considerando que o problema não está no sistema em si, mas que é o acusado quem terá de se ajudar adquirindo consciência das relações e regras do jogo do qual está participando ${ }^{333}$.

Podem-se citar, entre seus expoentes, Kitsuse e Cicourel.

De qualquer modo, não obstante as citadas diferenças, sob o enfoque do labelling approach, a criminalidade social, em geral, e as carreiras criminais, em particular, são encaradas como consequências do poder de definição de que dispõem os grupos sociais e as instâncias de controle ${ }^{334}$, o que explica sua denominação de teoria da rotulação social. Vê-se, pois, que o controle social, então estabelecido como seu objeto de estudo, transformou-se em objeto de críticas ${ }^{335}$.

Nota-se, assim, que a teorização proposta ocupou-se da importância da variabilidade do comportamento humano, da qualidade da ação social e da reação social a

\footnotetext{
${ }^{333}$ COULON, Alain. Etnometodologia. Tradução de Ephraim Ferreira Alves. Petrópolis: Vozes, 1995.

334 RÜTHER, Werner. La criminalidad (o el "delincuente") a traves de las definiciones sociales (o etiquetamiento). Doctrina Penal: Teoría y Práctica en las Ciencias Penales, Buenos Aires, v. 1, n. 1-4, p. 749-764, 1978.

${ }^{335}$ LARRAURI, Elena. La herencia de la criminología crítica. 2. ed. Madri: Siglo veintiuno de España, 2000.
} 
uma conduta e de seu impacto na futura desviação ${ }^{336}$, evidenciando, desse modo, repúdio aos modelos estáticos de abordagem do comportamento e da identidade dos indivíduos.

Trata-se de um novo olhar sobre a Criminologia, cujos focos se tornam as estruturas e os processos sociais. Ademais, a teoria propiciou uma abordagem mais abrangente em relação às posturas criminológicas anteriores, já que não se limitou ao estudo do desvio, mas também de áreas afins, tais como a Psiquiatria e todas as formas de estigmatização nas instituições totais ${ }^{337}$.

Além de introduzir na seara criminológica novos problemas e novas soluções, conforme aludido, a teoria também contribuiu com a formulação de uma nova linguagem, representativa dos conceitos por ela descritos. Dentre os novéis vocábulos destacam-se empresários morais, estereótipos, estigma, desviação secundária, cerimônias de degradação, instituições totais, entre outros ${ }^{338}$.

Consoante pôde depreender-se até aqui, o labelling approach ostenta uma postura contestatória de todo o sistema social, político e criminal estabelecido, o que se refletiu também na escolha de seus métodos de pesquisa.

Nesse sentido, elaborou severas críticas às estatísticas criminais, substituindo-as por métodos etnográficos de aferição da realidade ${ }^{339}$.

Por todas as transformações que aditou ao estudo criminológico é que alguns estudiosos entendem que o labelling approach propiciou a substituição do paradigma etiológico, encabeçado pela Escola Positivista, pelo paradigma da reação social ${ }^{340}$.

336 EINSTADTER, Werner J.; HENRY, Stuart. Criminological theory: an analysis of its underlying assumptions. 2. ed. Nova Iorque: Rowman \& Littlefield, 2006.

${ }^{337}$ DIAS, Jorge de Figueiredo; ANDRADE, Manuel da Costa. Criminologia: o homem delinqüente e a sociedade criminógena. 2 reimp. Coimbra: Coimbra Editora, 1997.

${ }^{338}$ DIAS, Jorge de Figueiredo; ANDRADE, Manuel da Costa. Criminologia: o homem delinqüente e a sociedade criminógena. 2 reimp. Coimbra: Coimbra Editora, 1997.

${ }^{339}$ Importante que se destaque que Cohen, ao desenvolver sua teoria subcultural, já ensaiava críticas ao uso das estatísticas criminais.

${ }^{340} \mathrm{Nem}$ todos os estudiosos concordam com a afirmação de que o labelling approach representa uma mudança de paradigma em relação aos estudos anteriores, especialmente no sentido em que a expressão é empregada por Kuhn. Por exemplo, na visão de Velo "não é de todo salutar ver os estudos de criminologia segundo dois extremos - um positivista, de cunho racista ou algo do gênero, outro crítico, radical ou democrático, a ponto de tê-los como centros paradigmáticos. Além dos aspectos que se relacionam com a delinquência e a criminalização serem complexos e por isso ensejarem a construção de vários saberes e utilidades, os estudos em Criminologia somente adquirem valor como ação imediata e real”. Cf. VELO, Joe Tennyson. Postura criminológica: entre a etnometodologia e o mito de Hermes. Ciências Penais. Revista da Associação Brasileira de Professores de Ciências Penais, São Paulo, v. 2, p. 114-129, jan./jun. 2005. p. 115. Para Anitua, os teóricos da rotulação social exageraram na originalidade de seu enfoque, uma vez que suas conclusões já haviam sido apresentadas em estudos anteriores de outras ciências. Cf. ANITUA, Gabriel Ignacio. Histórias dos pensamentos criminológicos. Tradução de Sérgio Lamarão. Rio de Janeiro: Revan, 2008. 
Os paradigmas são constitutivos da atividade científica, sendo que a transição de um ao outro consiste numa revolução científica.

Trata-se, nos termos das explicações de Kuhn, de uma reconstrução na área de estudo, a partir da adoção de novos princípios, sem se descartar, entretanto, os conhecimentos obtidos anteriormente. Ocorre uma mudança de enfoque, método e objetos de estudo, tendo em vista o câmbio da sustentação teórica por meio da qual os cientistas veem o mundo ${ }^{341}$.

Desse modo, atendo-se às proposições do autor, acredita-se que a teoria da rotulação social realmente representa a citada mudança de paradigmas, tendo em vista ter inserido objetos e métodos novos na investigação criminológica.

Defende-se, ademais, que o paradigma por ela inaugurado não foi superado, uma vez que as teorias críticas constroem suas teorizações a partir do pressuposto da seletividade do controle penal instituída pelo labelling approach ${ }^{342}$. A Criminologia crítica, pois, parte da irreversibilidade dos resultados do paradigma da reação social e das teorias do conflito ${ }^{343}$.

Contudo, a despeito de todas as qualidades creditadas ao labelling approach, acredita-se que uma única teoria criminológica, por mais completa e inovadora que seja, não é capaz de explicar um fenômeno social tão complexo como é o da criminalidade, podendo qualificar-se de ilusória uma perspectiva que almeje tal finalidade.

Fato é que "nenhuma corrente criminológica é auto-suficiente ou pode aspirar a oferecer explicação para todo e qualquer fenômeno da criminalidade",344.

Nos dizeres de Braithwaite, considerado um moderno expoente do labelling approach, o "crime não é uma construção unidimensional. Por essa razão não se deve ser excessivamente otimista em relação a uma teoria geral que se proponha a explicar todos os tipos de crime" 345 .

${ }^{341}$ KUHN, Thomas S. A estrutura das revoluções científicas. Tradução de Beatriz Viana Boeira e Nelson Boeira. 8. ed. São Paulo: Perspectiva, 1982.

${ }^{342}$ Nesse sentido ver: LARRAURI, Elena. La herencia de la criminología crítica. 2. ed. Madri: Siglo veintiuno de España, 2000, p. 139 e BRAITHWAITE, John. Crime, shame and reintegration. 16. impr. Nova Iorque: Cambridge, 2006, p. 5.

${ }^{343}$ ANDRADE, Vera Regina Pereira de. A ilusão da segurança jurídica: do controle da violência à violência do controle penal. 2. ed. Porto Alegre: Livraria do Advogado, 2003. p. 215.

${ }^{344}$ FERRO, Ana Luiza Almeida. Robert Merton e o funcionalismo. Belo Horizonte: Mandamentos, 2004. p. 99.

${ }^{345}$ BRAITHWAITE, John. Crime, shame and reintegration. 16. imp. Nova Iorque: Cambridge, 2006. p. 1. Braithwaite desenvolveu, na década de 1980, uma teoria que denominou da vergonha reintegrativa (reintegrative shaming), na qual procurou sintetizar postulados de diversas correntes criminológicas que 
Essa também nunca foi uma pretensão dos teóricos da rotulação social, o que se evidencia em suas propostas de investigação metodológica, e razão pela qual se negaram a perquirir as causas do primeiro ato delinquencial, no que se denomina criminalidade primária.

Nesse diapasão, Becker relatou que nunca foi intenção sua, nem dos outros precursores da teoria que com ele trabalharam, entre os quais cita Tannenbaum, Lemert, Kitsuse e Erikson, elaborar explicações etiológicas para o desvio ${ }^{346}$. Também Lemert afirmou que as causas originais do desvio podem ser muitas e diversificadas, razão pela qual não se ocuparia de identificá-las ${ }^{347}$.

A teoria, pois, deve ser incorporada em termos relativos, ou seja, como tentativa de elucidação de uma parcela dos fenômenos desviantes e em um momento específico de sua ocorrência, uma vez que nenhuma construção científica pode - e o labelling approach sequer almeja - elaborar uma explicação universal para o fenômeno delinquencial.

É nesses termos, pois, que sua proposta teórica e seus novos conceitos devem ser entendidos ${ }^{348}$.

considerava pertinentes, adicionando a eles o elemento da vergonha. Essas teorias são as do controle, da oportunidade, da subcultura delinquente, da associação diferencial e do labelling approach. Desta, adotou o conceito da estigmatização, chave do mecanismo de desviação secundária.

Entretanto, criticou a conceituação de estigmatização proposta por ater-se apenas aos seus aspectos negativos, uma vez que acreditava haver também aspectos positivos no estigma, e também por ser ele encarado pela rotulação social como algo permanente, imutável, o que defendia não ser.

Assim, para o autor, reintegrative shaming é um processo no qual os comportamentos considerados ofensivos são condenados, mas a pessoa que os praticou não, por ter sido ela reaceita na comunidade. Cf. BRAITHWAITE, John. Crime, shame and reintegration. 16. imp. Nova Iorque: Cambridge, 2006.

${ }^{346}$ BECKER, Howard S. Outsiders: studies in the sociology of deviance. Nova Iorque: The Free Press,1997.

${ }^{347}$ LEMERT, Edwin M. Social Pathology: a systematic approach to the theory of sociopathic behavior. 1. ed. Nova Iorque: Toronto: Londres: McGraw-Hill, 1951.

${ }^{348}$ Mesmo tendo inaugurado uma nova perspectiva de estudo da Criminologia, a teoria foi alvo de severas objeções, especialmente emanadas das correntes da Criminologia Crítica, surgidas a partir da década de 1970. As principais críticas elaboradas referem que a explicação proposta pela rotulação social é de médio alcance; que é sua intenção culpabilizar a sociedade e vitimizar o delinquente; que a desviação secundária é encarada de modo determinista; que há condutas que lesam bens jurídicos importantes para todos, não sendo, então, uma norma de proteção nesse sentido, idealização apenas dos poderosos; que as carreiras desviantes podem acontecer mesmo sem o etiquetamento público; que há pessoas que não se percebem como estigmatizadas a despeito de carregarem uma etiqueta negativa; entre outras. Sobre o assunto ver: BERGALLI, Roberto. Control y liberación en América Latina. Poder y Control: Revista hispanolatinoamericana de disciplinas sobre el control social, Barcelona, n.1, p. 101-106, 1987; GARCÍA-PABLOS DE MOLINA, Antonio. La normalidad del delito y el delincuente. Revista de la Facultad de Derecho de la Universidad Complutense, Madri, n. 11, p. 325-346, jun. 1986; CASTRO, Lola Aniyar de. Criminologia da reação social. Tradução de Ester Kosovski. Rio de Janeiro: Forense, 1983; TAYLOR, Ian; WALTON, Paul; YOUNG, Jack. La Nueva Criminología: contribución a una teoria social de la conducta desviada. Tradução de Adolfo Crosa. Buenos Aires: Amorrortu, 1997; EINSTADTER, Werner J.; HENRY, Stuart. Criminological theory: an analysis of its underlying assumptions. 2. ed. Nova Iorque: Rowman \& Littlefield, 2006; HERRERO, César Herrero. Criminologia. 2. ed. Madri: Dykinson, 2001; VOLD, George B.; BERNARD, Thomas J. Theoretical Criminology. 3. ed. Nova Iorque: Oxford University Press, 1986. 


\subsubsection{Redefinição do conceito de crime}

Em seu famoso livro intitulado Outsiders Becker alertou para a falta de consenso existente acerca do conceito de crime, ressaltando sua variação de acordo com o grupo social analisado ${ }^{349}$.

Essa discrepância explica-se por tratar-se de uma categoria definida em lei, estritamente relacionada à cultura, ao período histórico, ao grupo, à posição social e aos detentores do poder no momento de sua criação e vigência, uma vez que a proibição de uma conduta pode ser reflexo do desejo de promover valores ou estilos de vida particulares $^{350}$.

Em razão disso, Becker propôs-se a estabelecer uma nova definição para ele, de natureza sociológica, permeada pela afirmação do interacionismo existente entre todos os atores sociais.

Para o citado criminólogo, a característica que desponta evidente ao desvio é o fato de sua criação ocorrer no seio da sociedade, como sua resposta a determinada conduta praticada. Em outros termos, sem que um comportamento desperte uma reação social negativa não pode ser tido como desviante ${ }^{351}$.

Contudo, é aqui que o autor diferencia a mera infração de uma norma da desviação. Esta depende em parte da natureza do ato e em parte da reação social que gera. Sem que se consubstancie uma resposta de insatisfação o ato não é desviado, mas mera infração à norma $^{352}$.

Trata-se, pois, de uma definição reativa de desvio, na qual este e a reação social são encarados como termos recíprocos cuja compreensão só é possível conjuntamente. O crime não está na lei, tal qual a beleza, ele está apenas nos olhos de quem o observa ${ }^{353}$.

\footnotetext{
${ }^{349}$ O relativismo cultural, ínsito a concepção conflitual da sociedade adotada pela teoria, reflete-se na negação da existência de características próprias ao ato ilícito.

${ }^{350}$ EINSTADTER, Werner J.; HENRY, Stuart. Criminological theory: an analysis of its underlying assumptions. 2. ed. Nova Iorque: Rowman \& Littlefield, 2006.

${ }^{351}$ Não se quer dizer aqui que a sociedade cria o desvio, no sentido de que o crime decorre da condição social desprestigiada de determinados sujeitos ou de que é ela quem cria a pobreza, pois isso seria apontar causas para o desvio, função não intentada, e também refutada, pelo labelling approach. $\mathrm{O}$ que a teoria quer consignar é a ideia de que a sociedade cria o desvio ao implementar regras e aplicá-las em detrimento de certos sujeitos.

${ }^{352}$ BECKER, Howard S. Outsiders: studies in the sociology of deviance. Nova Iorque: The Free Press, 1997.

353 VOLD, George B.; BERNARD, Thomas J. Theoretical Criminology. 3. ed. Nova Iorque: Oxford University Press, 1986.
} 
Desde esse ponto de vista não se pode confrontar o delito sob outra perspectiva que não a coletiva, já que produto da colaboração tácita ou expressa de muitas pessoas ou grupos de pessoas. ${ }^{354}$.

Ademais, sob a ótica da teoria, o desvio não é mais visto por meio de um modelo simultâneo no qual todos os fatores impulsionadores da conduta desviada atuam num mesmo e único momento. Acredita-se num modelo sequencial em que as causas - as reações sociais - não atuam contemporaneamente, mas sim em degraus, devendo ser consideradas uma a uma, já que o comportamento final perpassa a explicação de cada qual $\operatorname{delas}^{355}$.

O crime passa a ser definido, então, não mais como um fenômeno individual, tal qual proposto pela Criminologia tradicional, mas sim de natureza complexa e coletiva, determinado pelas interações do indivíduo com seus pares e também com as instâncias de controle. Um ato não é qualificado como desviado em si mesmo, mas essa denominação deriva da interação do que o cometeu com os demais que a ele reagiram ${ }^{356}$, sendo certo que sem a resposta negativa dos outros não há qualificação efetiva do comportamento como desviante $^{357}$.

Nesse diapasão, dada a eminência da sociedade de conflito, o delito "é nada mais do que um ponto de vista sobre o anti-social que logrou impor-se sobre outros pontos de vista, em dado momento e lugar"358. Como uma conduta sistemática ou rotineira, não é algo inerente a ação ou a pessoa que a executa, mas é, em contrapartida, uma qualidade que se atribui ao ato e a quem o realizou ${ }^{359}$.

Nenhum comportamento humano é algo fechado em si mesmo, imutável, sendo aberto a interpretação, negociação e interação. Como parte da atividade humana, sua qualificação modifica-se em diferentes contextos sociais, os quais são capazes também de influenciá-lo e transformá-lo.

\footnotetext{
${ }^{354}$ BECKER, Howard S. Outsiders: studies in the sociology of deviance. Nova Iorque: The Free Press, 1997.

${ }^{355}$ BECKER, Howard S. Outsiders: studies in the sociology of deviance. Nova Iorque: The Free Press, 1997. É neste modelo que se insere o conceito de carreira, a qual é precedida pelos processos de criminalização primária e secundária, os quais serão estudados no presente capítulo.

${ }^{356}$ BECKER, Howard S. Outsiders: studies in the sociology of deviance. Nova Iorque: The Free Press, 1997.

${ }^{357}$ CASTRO, Lola Aniyar de. Criminologia da reação social. Tradução de Ester Kosovski. Rio de Janeiro: Forense, 1983.

${ }^{358}$ LARRAURI, Elena. La herencia de la criminología crítica. 2. ed. Madri: Siglo veintiuno de España, 2000. p. 65.

359 EINSTADTER, Werner J.; HENRY, Stuart. Criminological theory: an analysis of its underlying assumptions. 2. ed. Nova Iorque: Rowman \& Littlefield, 2006.
} 
Assim é que se torna indispensável a reação social negativa como conformadora do delito. A resposta da audiência social impulsiona a atuação dos mecanismos formais e informais de controle social e determina como deve ser rotulado determinado comportamento.

Ressalte-se que, consoante o entendimento proposto, tem-se que a atribuição da significação de um ato está intrinsecamente relacionada à publicidade de sua ocorrência e ao conhecimento que dele têm os demais, o que evidencia a grande seletividade e possibilidade de manipulação dessa categorização.

Consagra-se, desse modo, uma explicação afatorial, definitorial e social do desvio. Nos dizeres de Becker, uma postura contrária

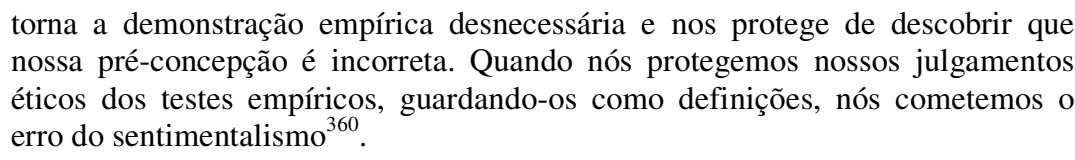
nossa pré-concepção é incorreta. Quando nós protegemos nossos julgamentos éticos dos testes empíricos, guardando-os como definições, nós cometemos o erro do sentimentalismo ${ }^{360}$.

Sua proposta, pois, repudia peremptoriamente que se assumam comportamentos como de antemão criminosos, uma vez que "o delito não existe. Só existem os atos. Estes atos muitas vezes recebem diferentes significados dentro dos diversos contextos sociais". 361

Essa acepção do crime como um fenômeno social implica que seu estudioso deve ter empatia e interesse em relação ao problema, que a comunidade deve participar da busca por soluções da criminalidade, já que nela se encontra seu nascedouro, e que devem ser buscados meios eficazes para seu enfrentamento, mas não para sua extirpação, realidade utópica $^{362}$.

Decorrência lógica da compreensão que tem do delito é a defesa, pela teoria, de que

o comportamento desviante pode ser modificado do exterior, sem incidir na personalidade, mudando-se as reações do grupo e modificando as regras que qualificam um comportamento de desviante. Evidentemente, é uma tarefa muito mais simples, do que tentar transformar a personalidade ${ }^{363}$.

${ }^{360}$ BECKER, Howard S. Outsiders: studies in the sociology of deviance. Nova Iorque: The Free Press, 1997. p. 202.

${ }^{361}$ CHRISTIE, Nils. El delito no existe. In: BAIGÚN, David et al. Estudios sobre Justicia Penal. Buenos Aires: Del Puerto, 2005. p. 555.

${ }^{362}$ GARCÍA-PABLOS DE MOLINA, Antonio. Momento actual de la reflexión criminológica. Estudios del Ministério Fiscal, Madri, n.1, p. 573-596, 1994.

${ }^{363}$ CASTRO, Lola Aniyar de. Criminologia da reação social. Tradução de Ester Kosovski. Rio de Janeiro: Forense, 1983. p. 135. 
Portanto, pode-se constatar que a teoria inovou ao elaborar um conceito sociológico de crime, considerando-o como um comportamento ontologicamente igual a todos os demais, todavia, com a única diferença de ter sido rotulado como tal pela sociedade e suas instituições.

\subsubsection{Redefinição do conceito de delinquente}

Não mais sendo considerado o crime como uma conduta anormal, estranha às demais, o criminoso também deixa de ser encarado como alguém diferente, desajustado, para ser analisado como um ser humano social e ajustado ${ }^{364}$.

Nesse sentido, tem-se que "os desviantes não são seres monstruosos, mas pessoas totalmente normais que se comprometeram com um modo de conduta em razão de processos sociais normais" ${ }^{365}$.

Entende-se que a figura do desviante emana de uma relação conflitiva em que certos atores, os quais fazem uma leitura particular do sistema e das regras sociais, declaram criminosos os desobedientes dos valores e normas que defendem.

Prova desse conflito é o conceito de outsider formulado por Becker, o qual comporta duas facetas antagônicas: a da sociedade e a do encarado como desviante. Pela primeira, outsider é um tipo especial de pessoa, na realidade, alguém em quem não se pode confiar, devido ao fato de ter violado uma norma de observância obrigatória. Pela segunda, outsiders são os competentes para julgá-lo, os quais lhe desejam impor o respeito a uma regra com a qual ele não concorda ${ }^{366}$.

Ao longo de sua vida e em cada ambiente social em que se encontram, as pessoas desempenham papéis diferentes, os quais geram para elas direitos e obrigações. Isso porque a sociedade espera delas atitudes condizentes com o papel que assumiram, como se ele determinasse de antemão a forma como elas deveriam ser tratadas e também seus padrões de comportamento frente aos demais.

\footnotetext{
${ }^{364}$ Nesse sentido, o labelling approach assume uma postura crítica em relação aos estudos anteriores do delito, cuja preocupação principal era a de descobrir as razões ou motivos da prática delitiva, uma vez que isto implicava na assunção de que há condutas inerentemente ilegais e características pessoais que fazem com que o sujeito opte por esse tipo de comportamento. Cf. BECKER, Howard S. Outsiders: studies in the sociology of deviance. Nova Iorque: The Free Press, 1997.

${ }^{365}$ CASTRO, Lola Aniyar de. Criminologia da reação social. Tradução de Ester Kosovski. Rio de Janeiro: Forense, 1983. p. 134.

${ }^{366}$ BECKER, Howard S. Outsiders: studies in the sociology of deviance. Nova Iorque: The Free Press, 1997.
} 
Assim, as obrigações, em realidade, são mais do que meras obrigações, são expectativas sociais que os sujeitos esperam que se cumpram por alguém que exerce aquele papel. Por vezes, essas expectativas estão tão arraigadas nos membros de dada sociedade que se tornam normas sociais, padrões de juízo da média da população.

A importância desse mecanismo é que da expectativa da audiência social que depende a qualificação do desvio e do desviante ${ }^{367}$. O indivíduo é tido como desviante quando o comportamento por ele realizado não corresponde com seu papel, ou melhor, com o papel que a média da sociedade considera adequado.

Não são, pois, necessariamente, os tipos de condutas praticadas que diferenciam os delinquentes dos que não o são, mas sim as respostas dos membros que compõem a sociedade, identificando e interpretando o comportamento como desviado, que transformam seu autor em delinquente.

A conduta praticada é apenas um fator - e talvez nem seja o mais importante - para que a etiqueta de criminoso seja conferida a alguém ${ }^{368}$.

Trata-se de uma falsa definição dos que ofenderam a lei como se fossem criminosos permanentes e destinados a uma vida no crime. Tudo isso causado por uma reação social que torna a criminalidade necessária, senão atrativa ${ }^{369}$.

Para os teóricos do labelling approach, aceitar passivamente a afirmação de que delinquente é o que realiza um ato contra a lei implica assumir a reação social como aproblemática e ignorar o fato de que sob esse rótulo negativo estão englobadas pessoas falsamente acusadas, bem como apenas uma pequena parcela dos infratores, a composta pelos que foram assim identificados ${ }^{370}$.

Ademais, para esses pensadores o crime representa uma atitude comportamental da maioria das pessoas e está disseminado por todas as classes sociais.

Todos têm impulsos destinados ao desvio, mas apenas alguns os efetivam, em dependência do processo de comprometimento que estabeleceram com as instituições e com as normas comportamentais. Os mais comprometidos com o contexto social, que

${ }^{367}$ CASTRO, Lola Aniyar de. Criminologia da reação social. Tradução de Ester Kosovski. Rio de Janeiro: Forense, 1983.

${ }^{368}$ LILLY, Robert J.; CULLEN, Francis T.; Ball, Richard A. Criminological theory: context and consequences. 2. ed. Sage: Thousand Oaks, 1995.

${ }^{369}$ LILLY, Robert J.; CULLEN, Francis T.; Ball, Richard A. Criminological theory: context and consequences. 2. ed. Sage: Thousand Oaks, 1995.

${ }^{370}$ LILLY, Robert J.; CULLEN, Francis T.; Ball, Richard A. Criminological theory: context and consequences. 2. ed. Sage: Thousand Oaks, 1995. 
sabem que podem perder muito ao optar pelo delito, tendem a não seguir esses impulsos. Em oposição, os que não têm nada a perder têm mais facilidade em obedecê-los ${ }^{371}$.

Contudo, na realidade, a grande diferença que existe aqui se refere aos controles sociais - formais e informais -, cuja resposta ofertada não é a mesma para todos os que realizaram o mesmo ato, razão pela qual, ao final desse processo, só alguns - geralmente os menos comprometidos - são considerados desviantes ${ }^{372}$.

Assim, a característica comum que pode ser vislumbrada em todos os desviantes é o fato de terem sido etiquetados pela sociedade como tal, e nada mais. Os delinquentes são, entre todos os que executaram a mesma conduta, os poucos sujeitos que receberam esse atributo, como resultado de um processo de etiquetamento, definição, identificação, segregação, descrição e ênfase ${ }^{373}$.

Nesse diapasão,

o estereótipo delinqüente ou desviante está solidamente relacionado às reações do grupo contra os atos de perpetração do antissocial. O comportamento de um indivíduo é, na realidade, fator predisponente para sua consideração como delinquiente ou desviante. A decisão crucial, contudo, repousa sobre o grupo e seus órgãos de controle social que podem, ou não, classificá-lo como desviante. Isso significa que o comportamento atribuído fora do contexto social é insuficiente para constituir 'deviance' social. Além disso, muitas vezes, pessoas que não foram absolutamente desviantes no seu comportamento tornaram-se rotuladas como tal pelos órgãos de controle social ${ }^{374}$.

Desse modo, consoante o entendimento do criminoso como uma categoria heterogênea de pessoas e na qual não se englobam todos os autores de desvios, já que seletivamente etiquetados, impossível salientar fatores comuns de personalidade ou situação de vida que expliquem o desvio e determinem os desviantes. Impossível, assim, dividir o mundo entre os bons e os malvados, os respeitadores da lei e os delinquentes.

Fato é que

não podemos ceder ao apelativo urgente para uma análise e compreensão profundas da realidade, a partir de categorias racionais 'claras' e 'objetivas', mas também acomodatícias, cuja 'clareza' e 'objetividade' nos dão segurança e conferem ao nosso discurso aquele impacto desejado. Categorias racionais muitas vezes bi-polares e que, pela 'clareza' e 'objetividade' de sua bipolaridade, acabam nos cegando e obliterando nosso pensamento [...] Se conseguimos transcender a bi-polaridade dessas categorias, talvez possamos, não

\footnotetext{
${ }^{371}$ BECKER, Howard S. Outsiders: studies in the sociology of deviance. Nova Iorque: The Free Press, 1997. Exemplificativamente pode-se afirmar que os que têm um bom emprego, provêm da classe média, têm uma reputação pela qual zelar raramente obedecem a seus impulsos desviantes. Cf. BECKER, Howard S. Outsiders: studies in the sociology of deviance. Nova Iorque: The Free Press, 1997.

${ }^{372}$ BECKER, Howard S. Outsiders: studies in the sociology of deviance. Nova Iorque: The Free Press, 1997.

${ }^{373}$ TANNEMBAUM, Frank. Crime and the community. Nova Iorque: Columbia University Press, 1951. p. 19-20.

${ }^{374}$ AMAR, Ayush Morad. Temas de Criminologia. São Paulo: Resenha Universitária, 1982. v. II. p 72.
} 
simplesmente enxergar outras coisas na realidade, mas enxergar uma outra realidade nas coisas ${ }^{375}$.

Isso posto, em obediência a sua interpretação do corpo social como rotulador de comportamentos substancialmente iguais de maneiras diversas, desmistificando-se, assim, uma pretensa e negativa peculiaridade do criminoso, torna-se patente o desenvolvimento, pela teoria, de uma análise que valorizava o delinquente, tentando compreendê-lo e pregando posturas cada vez menos interventivas em relação a ele ${ }^{376}$.

\subsubsection{Redefinição do conceito de pena}

A punição nada mais é do que um ato de poder bruto, representação do poder do público $^{377}$. A pena apresenta-se como uma violência institucional realizada pelo Estado e pelas polícias, bem como um instrumento de reprodução da violência estrutural, ou seja, a repressão das necessidades reais dos indivíduos e dos direitos humanos ${ }^{378}$.

Os teóricos do labelling approach defendem que a pena só é capaz de atingir um objetivo, qual seja, o de aumentar a criminalidade, que como já visto pensam ser criada pela sociedade e pelos sistemas penais, por meio de suas reações a determinado ato. Isso porque acreditam que os mecanismos de aprendizagem de como ser delinquente são avigorados pelas instituições encarregadas, em tese, de dissuadi-los.

Assim, a criminalidade, "mais do que um dado preexistente comprovado objetivamente pelas instâncias oficiais, é uma realidade social de que a ação das instâncias oficiais é elemento constitutivo"379.

Evidente, então, que desacreditam o fim de ressocialização social atribuído à pena.

A teoria critica o conceito e, precipuamente, a possibilidade de ressocialização, uma vez que defende ser a sociedade criminógena: ela é quem gera a delinquência e não o autor

${ }^{375}$ SÁ, Alvino Augusto de. Algumas ponderações acerca da reintegração social dos condenados à pena privativa de liberdade. Disponível em <www.eap.sp.gov. br/ponderacoes.pdf>. Acesso em 25 mai. 2007. p. 16.

${ }^{376}$ BRAITHWAITE, John. Crime, shame and reintegration. 16. imp. Nova Iorque: Cambridge, 2006.

377 VERDIER, Raymond. Jean Carbonnier, historien-sociologue du pénal et du non-droit pénal. In: HOAREAU-DODINAU, Jacqueline; TEXIER, Pascal (Orgs.). La peine. Discours, pratiques, représentations. Paris: Pulim, 2005.

${ }^{378}$ BARATTA, Alessandro. Direitos humanos: entre a violência estrutural e a violência penal. Fascículos de Ciências Penais, Porto Alegre, v. 6. n. 2, p. 44-61, abr. /jun. 1993.

${ }^{379}$ BARATTA, Alessandro. Criminologia crítica e crítica do direito penal: introdução à sociologia do direito penal. Tradução de Juarez Cirino dos Santos. 2. ed. Rio de Janeiro: Freitas Bastos, 1999. p. 178-179. 
do ilícito isoladamente ${ }^{380}$.

Erige-se não só contra sua concepção, mas principalmente contra sua legitimidade, por não ter lógica os próprios criadores da criminalidade estarem habilitados a "tratá-la". Ademais, sendo normais o crime e o criminoso, inútil propugnar pela melhora deste.

Importante consignar que não há consenso acerca do significado do termo ressocialização, que, ao ser explanado por correntes de pensamento muito diversas, torna evidente sua ambiguidade. Essa discrepância parece evidenciar que um conceito tão polêmico só pode se legitimar em seu aspecto negativo - como oposição ao retribucionismo da pena ${ }^{381}$.

Há programas máximos de ressocialização, que exigem uma forte incidência no comportamento e valores do sujeito submetido a tratamento, bem como programas mínimos, os quais buscam fazer apenas com que ele respeite a lei.

De qualquer forma, não sendo o autor do ilícito carente de socialização, considerase que nenhum programa ressocializador, seja ele máximo ou mínimo, faça sentido.

Não obstante o explanado até aqui, é certo que a própria realidade "revela que a ressocialização é impossível de ser alcançada, seja porque ela, em si mesma, é paradoxal, seja porque, os meios oferecidos para sua execução são imprestáveis"382 .

O tratamento penal, pois, é qualificado como ilegítimo e ineficaz pelos doutrinadores da rotulação social. Ademais, consonante o mencionado no início deste excerto, defende-se que

a intervenção do sistema penal, especialmente as penas detentivas, antes de terem um efeito reeducativo sobre o delinqüente determinam, na maioria dos caos, uma consolidação da identidade desviante do condenado e seu ingresso em uma verdadeira e própria carreira criminosa ${ }^{383}$.

$\mathrm{O}$ ato de rotular e tratar os violadores de norma como criminosos produz, pois, como consequência, a criação do comportamento que se quer coibir.

\footnotetext{
${ }^{380}$ A possibilidade ressocializante ou de tratamento atribuído a pena criminal é também criticada em outros estudos criminológicos, psicológicos e psiquiátricos, dentre os quais podem ser citados os da Criminologia crítica, de algumas correntes neomarxistas, funcionalistas, bem como da psicoanálise e da psicologia, entre outras.

${ }^{381}$ GARCÍA-PABLOS DE MOLINA, Antonio. La supuesta función resocializadora del Derecho Penal: utopia, mito y eufenismo. Anuario de Derecho Penal y Ciencias Penales, Madri, v. 32, n. 2, p. 645-700, mai.Iago. 1979.

${ }^{382}$ LYRA, Roberto; JÚNIOR, João Marcello de Araújo. Criminologia. 2 ed. Rio de Janeiro: Forense, 1990. p. 199.

383 BARATTA, Alessandro. Criminologia crítica e crítica do direito penal. Tradução de Juarez Cirino dos Santos. 2. ed. Rio de Janeiro: Freitas Bastos, 1999. p. 90.
} 
Desse modo, evidencia-se que as consequências da intervenção estatal são complexas e que não se cumprem as funções que o senso comum a creditam.

A punição como retribuição é falha para reformar, para transformar o caráter de um indivíduo. Prova disso é o grande número de reincidência entre os ex-detentos ${ }^{384}$. Por mais que se criem novos sistemas de punição eles não conseguem assumir satisfatoriamente tal função.

Fato é que, conforme descreve Tannenbaum, quanto mais se trabalha para reformar o menino mau, mais esse mal cresce sobre suas mãos, no que ele denomina de dramatização do mal. Diante disso, quanto menos se falar sobre o fato melhor. Mesmo que quem o discuta tenha boas intenções é melhor que se cale ou fale sobre outros assuntos ${ }^{385}$.

Ainda nesse sentido, verifica-se que a pena "é a reprodução da violência e a reprodução da freguesia das cadeias. A gaiola é feita para reproduzir a própria freguesia e a reproduz com perfeição. É o processo de condicionamento para o homem voltar"386.

A prisão, por sua vez, a mais gravosa das reprimendas, além de ser forma de violência institucional, também concentra violências entre indivíduos e de grupo. Além do mais, exerce as funções de reprodução do status quo e institucionalização da desigualdade social, não obstante suas funções simbólicas de estereotipização do criminoso e percepção da criminalidade como ato de pessoas e não de conflitos sociais ${ }^{387}$.

Desse modo, "que a ressocialização do delinquente tenha sido função efetiva do cárcere e possa ser realmente considerada como fim alcançável através de medidas privativas de liberdade, aparece definitivamente como uma ilusão"388.

Portanto, a pena não tem nenhum efeito positivo sobre aquele que a suporta. Ela não ressocializa, mas estigmatiza; não limpa, mancha ${ }^{389}$. A função que ela cumpre com louvor é a de introduzir o sujeito em um rito de degradação do seu status, o qual tem o efeito de causar significativas mudanças em sua identidade ${ }^{390}$.

\footnotetext{
${ }^{384}$ TANNEMBAUM, Frank. Crime and the community. Nova Iorque: Columbia University Press, 1951.

385 TANNEMBAUM, Frank. Crime and the community. Nova Iorque: Columbia University Press, 1951.

386 ZAFFARONI, Eugenio Raúl. Função da Criminologia nas sociedades democráticas. Fascículos de Ciências Penais, Porto Alegre, v. 2, n. 11, p. 163-176, nov. 1989. p. 171.

${ }^{387}$ BARATTA, Alessandro. Direitos humanos: entre a violência estrutural e a violência penal. Fascículos de Ciências Penais, Porto Alegre, v. 6. n. 2, p. 44-61, abr./.jun. 1993.

${ }^{388}$ BARATTA, Alessandro. Criminologia e Dogmática Penal. Passado e futuro do modelo integral da Ciência Penal. Revista de Direito Penal, Rio de Janeiro, n. 31, p. 5-37, jan./jun. 1981. p. 10.

389 GARCÍA-PABLOS DE MOLINA, Antonio. La normalidad del delito y el delincuente. Revista de la Facultad de Derecho de la Universidad Complutense, Madri, n. 11, p. 325-346, jun. 1986.

${ }^{390}$ SCHUR, Edwin M. Sociologia del diritto. Tradução de Paola Montagner. Bologna: Mulino, 1970.
} 
Tal ocorrência será melhor compreendida no decorrer do subcapítulo seguinte, quando será explanada a ação do sistema penal ao incidir sobre os comportamentos e sujeitos.

\subsection{PROCESSOS FORMAIS DE CRIMINALIZAÇÃO}

Os processos de criminalização realizam-se por meio da seleção, pelos mecanismos de controle social formados pelas agências do sistema penal, de pessoas e condutas a serem punidas $^{391}$.

Note-se, então, que o controle social e o sistema penal são pilastras da criminalização, sem cujos conceitos não pode ela ser compreendida.

Assim, mister a elucidação crítica de ambos.

O termo controle social foi primeiramente utilizado por Ross, para referir-se aos mecanismos por meio dos quais a sociedade exerce seu domínio sobre os indivíduos, e os força a conformar-se com suas normas e valores ${ }^{392}$.

Trata-se de instâncias de regulação dos corpos desde uma situação de poder, ou em concordância com ele, em benefício da ordem instituída ${ }^{393}$.

Ross distingue o citado controle em ético e político, sendo a preponderância de cada qual variável de acordo com a sociedade considerada. O primeiro seria o realizado pelas associações religiosas, pela arte ou pela opinião pública, cuja coerção baseia-se mais em um sentimento do que em sua utilidade. O segundo, por sua vez, exercido pela lei e pela educação, tem por referência o poder de fiscalização, de polícia ${ }^{394}$.

Atualmente, essas espécies de coerção social, com algumas modificações, são aludidas pelas expressões controle social informal e formal, respectivamente. O primeiro refere-se à fiscalização realizada pela sociedade civil e suas instituições, enquanto o

\footnotetext{
${ }^{391}$ Consoante já se consignou no presente trabalho, o controle social é foco central do estudo da teoria, já que todas as explicações que seus estudiosos fornecem para a criminalidade perpassam tal conceito, acentuandose, pois, seu papel coconstitutivo na criação do desvio. Contudo, embora todos os mecanismos de controle sejam suficientes para criar do desvio e rotular o desviante, a coerção formalizada pelo Estado é a mais danosa delas, razão pela qual se optou neste excerto por ater-se especificamente a sua análise.

${ }^{392}$ ROSS, Edward A. Social control. In: COSER, Lewis A.; ROSENBERG, Bernard (Ed.). Social theory: a book of readings. Nova Iorque: Macmillan, 1957.

${ }^{393}$ VISCARDI, Nilia. Disciplinamiento, control social y estigma: tres conceptos para una sociología del conflito: el caso de la violencia en el espacio escolar en Uruguay. Revista Sociologias, Porto Alegre, v. 1, n. 1, p. 168-199, jan./jun. 1999.

${ }^{394}$ ROSS, Edward A. Social control. In: COSER, Lewis A.; ROSENBERG, Bernard (Ed.). Social theory: a book of readings. Nova Iorque: Macmillan, 1957.
} 
segundo é o exercido pelas agências de controle ligadas ao poder do Estado de punir, as quais, em razão disso, operam a criminalização ou convergem na sua produção. Trata-se, pois, do sistema penal.

Este, sob a ótica da teoria em análise, não é considerado um mecanismo imparcial e efetivo de solução de conflitos. Isso porque o labelling approach evidenciou que toda intervenção do sistema penal é inevitavelmente violenta, seletiva e estigmatizante e, quanto mais conflitos se lhe derivem, a concentração verticalista de poder é mais forte e as relações horizontais estão mais diluídas, ou seja, a comunidade mais desintegrada ${ }^{395}$.

Para a teoria, o que ocorre é que o poder de criminalização e seu exercício estão estreitamente ligados à estratificação e à estrutura antagônica da sociedade ${ }^{396}$.

Ainda neste sentido, pode-se afirmar que

a convicção errônea de que o Direito Penal pode solucionar os problemas da sociedade está muito arraigada, especialmente no pensamento mais conservador. Esta crença absoluta é própria de uma sociedade que diante dos problemas não é capaz de analisar sua origem. É mais própria de uma sociedade infantil, que desejaria que o mundo estivesse dividido como nos filmes do velho oeste: os bons e os maus ${ }^{397}$.

Portanto, a tentativa de impedir, castigar e prevenir o desvio, impulsionando, assim, a ação do controle social, pode mesmo criá-lo ${ }^{398}$.

Outra característica que desponta do sistema penal refere-se ao fato de que as funções atribuídas às suas agências, encarregadas de atuarem no combate a criminalidade, são bastante distintas das realmente exercidas por elas, podendo se defender que têm elas uma história privada e outra pública ${ }^{399}$. Ademais, vislumbra-se que suas ações são guiadas não apenas por fatores legais, mas também por definições ilegais das situações e das pessoas envolvidas, conforme poderá verificar-se nos itens subsequentes deste capítulo.

Importante ressaltar que

é quando o enfoque macrossociológico se desloca do comportamento desviante para os mecanismos de controle social dele, em especial para o processo de criminalização, que o momento crítico atinge sua maturação na Criminologia, e

\footnotetext{
${ }^{395}$ ZAFFARONI, Eugenio Raúl. Os limites do aprisionamento. Fascículos de Ciências Penais, Porto Alegre, v. 1, n.3, p. 51-55, mai. 1988.

${ }^{396}$ BARATTA, Alessandro. Criminologia crítica e crítica do direito penal: introdução à sociologia do direito penal. Tradução de Juarez Cirino dos Santos. 2. ed. Rio de Janeiro: Freitas Bastos, 1999.

${ }^{397}$ GIMÉNEZ-SALINAS COLOMER, Esther. La mediación en el sistema de justicia juvenil: uma visión desde el derecho comparado. Eguzkilore. Cuaderno del Instituto Vasco de Criminología, San Sebastián, n.10, p. 193-212, dez. 1996. p. 194.

${ }^{398}$ TAYLOR, Ian; WALTON, Paul; YOUNG, Jack. La Nueva Criminología: contribución a una teoria social de la conducta desviada. Tradução de Adolfo Crosa. Buenos Aires: Amorrortu, 1997.

${ }^{399}$ LEMERT, Edwin M. Social Pathology: a systematic approach to the theory of sociopathic behavior. 1. ed. Nova Iorque: Toronto: Londres: McGraw-Hill, 1951.
} 
ela tende a transformar-se de uma teoria da criminalidade em uma teoria crítica e sociológica do sistema penal. De modo que, deixando de lado possíveis diferenciações no seu anterior, ela se ocupa hoje em dia, fundamentalmente, da análise dos sistemas penais vigentes ${ }^{400}$.

Para o labelling approach, é principalmente na esfera do controle social formal que se identificam os processos responsáveis pela definição do crime e do criminoso, sendo seu foco de estudo a perquirição das condições que determinam o grau de probabilidade de que certos comportamentos e certos indivíduos sejam definidos como criminosos pelo sistema penal, bem como as consequências dessa definição ${ }^{401}$.

Os mencionados processos podem ocorrer em três direções e momentos distintos: a formulação de uma lei, a aplicação da mesma e a execução de uma reprimenda.

As três fases da criminalização que serão abaixo discutidas identificam-se com os três níveis explicativos propostos pela teoria. Na criminalização primária, foca-se o mecanismo de definição da conduta como desviada; na criminalização secundária, o processo de seleção que captura alguns dos autores das condutas proibidas; e na criminalização terciária, o impacto da atribuição do status de criminoso na identidade do indivíduo $^{402}$.

De qualquer modo, a despeito da existência dessas três facetas, o processo de aplicação da justiça penal é compreendido de forma integrada, já que qualquer alteração em um dos subsistemas o modifica como um todo.

O que a teoria destaca é que quanto mais o indivíduo adentra nos citados processos, menores as esperanças de interromper o ciclo criminalizante vicioso que ele encerra ${ }^{403}$. Acredita, nesse sentido, que à medida que a interação entre os seres torna-se formal e institucionalizada há uma tendência a sua energia inventiva reduzir-se cada vez mais, até limitar-se a preocupação apenas com as condições existenciais, explorando-se, cada vez menos, a diversidade e a potencialidade dos sujeitos ${ }^{404}$.

\footnotetext{
${ }^{400}$ ANDRADE, Vera Regina Pereira de. A ilusão da segurança jurídica: do controle da violência à violência do controle penal. 2. ed. Porto Alegre: Livraria do Advogado, 2003. p. 218.

${ }^{401}$ BARATTA, Alessandro. Criminologia crítica e crítica do direito penal: introdução à sociologia do direito penal. Tradução de Juarez Cirino dos Santos. 2. ed. Rio de Janeiro: Freitas Bastos, 1999. p. 112.

${ }^{402}$ ANDRADE, Vera Regina Pereira de. A ilusão da segurança jurídica: do controle da violência à violência do controle penal. 2. ed. Porto Alegre: Livraria do Advogado, 2003.

403 RÜTHER, Werner. La criminalidad (o el "delincuente") a traves de las definiciones sociales (o etiquetamiento). Doctrina Penal: Teoría y Práctica en las Ciencias Penales, Buenos Aires, v. 1, n. 1-4, p. 749-764, 1978.

404 EINSTADTER, Werner J.; HENRY, Stuart. Criminological theory: an analysis of its underlying assumptions. 2. ed. Nova Iorque: Rowman \& Littlefield, 2006.
} 
Formulada essa crítica, evidente que a lida com esse fenômeno deve ser diferenciada da propugnada pela Criminologia tradicional. Para os novos estudiosos

a Política Criminal deve ser considerada em função de novos elementos conceituais: valor da utilidade da incriminação penal de certos comportamentos em relação ao preço que exige o controle social dos mesmos, tanto a nível individual (estigmatização) como geral (custos de prevenção e tratamento) ${ }^{405}$.

Pelo que foi explanado até aqui, fica evidente que, sob a ótica do labelling approach, "não há como compreender a criminalidade se não se estuda a ação do sistema penal, que a define e reage contra ela, começando pelas normas abstratas até as instâncias oficiais" ${ }^{, 406}$. Para Becker esse novo modo de se estudar o desvio traz o começo da consideração da moral na Sociologia contemporânea, uma vez que, quando esta clarifica as relações entre as pessoas e as instituições, influencia as avaliações morais que se faz $\operatorname{delas}^{407}$.

\subsubsection{Criminalização primária}

A criminalização primária identificada com o controle social formal perquire o processo de criação das normas penais, a definição dos bens jurídicos protegidos, as condutas que devem ser criminalizadas, a qualidade e a quantidade das penas e a distribuição do poder para operar com esse mecanismo de criminalização na sociedade ${ }^{408}$. Consubstancia-se, pois, no "ato e o efeito de sancionar uma lei penal material que incrimina ou permite a punição de certas pessoas" ${ }^{409}$.

Seu estudo insere-se na macroperspectiva explicativa do labelling approach, ao dirigir-se à maneira como se define, numa sociedade, o que é a criminalidade.

Nas sociedades homogêneas poderia se pensar na existência de um consenso sobre valores e normas adequadas para discipliná-los, o que não pode mais ser defendido nas modernas sociedades ocidentais, heterogêneas e conflituais por excelência. Hodiernamente

${ }^{405}$ CASTRO, Lola Aniyar de. Criminologia da reação social. Tradução de Ester Kosovski. Rio de Janeiro: Forense, 1983. p. 135.

${ }^{406}$ GROSNER, Marina Quezado. A seletividade do sistema penal na jurisprudência do Superior Tribunal de Justiça: o trancamento da criminalização secundária por decisões em habeas corpus. São Paulo: IBCCRIM, 2008. p. 53.

${ }^{407}$ BECKER, Howard S. Outsiders: studies in the sociology of deviance. Nova Iorque: The Free Press, 1997. ${ }^{408}$ GROSNER, Marina Quezado. A seletividade do sistema penal na jurisprudência do Superior Tribunal de Justiça: o trancamento da criminalização secundária por decisões em habeas corpus. São Paulo: IBCCRIM, 2008.

${ }^{409}$ ZAFFARONI, Eugenio Raúl et al. Direito Penal Brasileiro. 2. ed. Rio de Janeiro: Revan, 2003. v. 1. p. 43. $\mathrm{Na}$ esfera do controle social informal, em contrapartida, investigam-se as definições informais do senso comum e sua influência perante determinados comportamentos. 
não podem mais ser analisadas as leis vigentes como produtos límpidos e democráticos dos anseios de determinada sociedade.

Em realidade, são apenas algumas pessoas que podem determinar a institucionalização das normas nas quais creem e a escolha dos que podem fazê-lo resolvese por uma questão de poder econômico e político. Todos querem ou tentam impor suas regras aos demais grupos sociais, mas só obtêm êxito na tarefa os que possuem o poder para tanto ${ }^{410}$.

As leis têm as formas que têm, disciplinam as condutas que disciplinam, por terem sido moldadas por determinadas biografias pessoais ou grupos de pressão, bem como pelo contexto social em que se erigiram ${ }^{411}$. A incriminação das condutas não obedece a critérios objetivos, tal qual a necessidade de proteção dos bens comuns, sendo, de modo diverso, guiada por critérios de grupo, parciais, discriminadores e dirigidas contra os que estão longe do êxito, do dinheiro e do poder ${ }^{412}$.

A definição legal de certas condutas como crimes, para os teóricos do labelling approach, é parte de um processo maior que se desenvolve na sociedade, no qual seus membros definem o desvio ao taxar certos atos como maus e tomar providências para minimizar sua prática ou extirpá-1o ${ }^{413}$.

Para Becker os regramentos são criados por iniciativa dos empresários morais ${ }^{414}$, sendo certo que entre eles há os que objetivam apenas impor suas concepções morais aos demais e os que estão ligados a causas humanitárias ${ }^{415}$. São eles que, numa sociedade em que não há consensos, mas sim conflitos culturais, podem impor aos demais sua crença na danosidade e na necessidade de repressão de determinada conduta. Isso porque os empresários morais são os que detêm poder social suficiente para infundir sua versão de moralidade aos demais.

\footnotetext{
${ }^{410}$ BECKER, Howard S. Outsiders: studies in the sociology of deviance. Nova Iorque: The Free Press, 1997.

411 EINSTADTER, Werner J.; HENRY, Stuart. Criminological theory: an analysis of its underlying assumptions. 2. ed. Nova Iorque: Rowman \& Littlefield, 2006.

${ }^{412}$ HERRERO, César Herrero. Criminologia. 2. ed. Madri: Dykinson, 2001.

413 VOLD, George B.; BERNARD, Thomas J. Theoretical Criminology. 3. ed. Nova Iorque: Oxford University Press, 1986.

${ }^{414} \mathrm{O}$ conceito de empresários morais (moral entrepreneurs) foi desenvolvido por Becker em seu livro Outsiders e constitui um dos pontos centrais da teoria do labelling approach. Eles podem ser de dois tipos os que criam as normas e os que se encarregam de sua imposição.

415 Becker não parece qualificar as intenções dos poderosos empresários morais sempre como "maldosas". Crê que eles, ao normatizarem regras, podem visar a interesses que os beneficiem diretamente ou que acreditam mereçam tratamento penal.
} 
O protótipo do criador de normas pode ser identificado como crusading reformer. Trata-se de uma pessoa que crê na insuficiência das normas já existentes e que nada pode estar certo enquanto regras não disciplinarem a situação e a corrigirem ${ }^{416}$.

Note-se que dessa tarefa de criação de regras, exercida unilateralmente, emana a possibilidade de criar os delitos e, consequentemente, um novo grupo de delinquentes.

Nesse sentido, representa a efetivação de uma forma de reação social $^{417}$ : é a movimentação de uma pessoa ou de um grupo de pessoas contrárias a determinada situação social e que desejam, por isso, criminalizá-la.

Ainda que se defenda que toda a sociedade será beneficiada com a promulgação de um novo crime, sendo por isso as campanhas desse tipo realizadas em nome de todos, elas são sempre promovidas por seus favorecidos diretos, que são os grandes interessados em sua aprovação $^{418}$. Destaque-se que, com a promulgação do novo ilícito, o grupo beneficiado consegue o suporte das agências de controle social formal para a manutenção de seus interesses, o que tem o efeito de solidificar seu poder e institucionalizar seu domínio sobre os demais grupos sociais ${ }^{419}$.

Consoante já se consignou no presente trabalho, não há condutas que, por sua natureza, mereçam ser criminalizadas. Os comportamentos considerados desviantes e os padrões daqueles que o julgam inaceitáveis são produtos exatamente do mesmo processo de construção social, sendo certo que, muitas vezes, os padrões de um grupo coincidem com os desvios do outro ${ }^{420}$.

Exemplifica-se a situação. Quando uma legislação determina a ilegalidade da preparação anti-higiênica de determinada carne, ela está promovendo um conjunto particular de valores e tornando desviantes todos aqueles que aprontam o alimento sem observância das exigidas condições de higiene. Entretanto, se os vegetarianos consideram toda a ingestão de animal uma morte, eles estão considerando desviantes não apenas as pessoas que o fazem, mas também a regulação do modo de sua preparação ${ }^{421}$.

\footnotetext{
${ }^{416}$ BECKER, Howard S. Outsiders: studies in the sociology of deviance. Nova Iorque: The Free Press, 1997.

${ }^{417}$ CASTRO, Lola Aniyar de. Criminologia da reação social. Tradução de Ester Kosovski. Rio de Janeiro: Forense, 1983.

418 VOLD, George B.; BERNARD, Thomas J. Theoretical Criminology. 3. ed. Nova Iorque: Oxford University Press, 1986.

${ }^{419}$ VOLD, George B.; BERNARD, Thomas J. Theoretical Criminology. 3. ed. Nova Iorque: Oxford University Press, 1986.

${ }^{420}$ EINSTADTER, Werner J.; HENRY, Stuart. Criminological theory: an analysis of its underlying assumptions. 2. ed. Nova Iorque: Rowman \& Littlefield, 2006.

${ }^{421}$ EINSTADTER, Werner J.; HENRY, Stuart. Criminological theory: an analysis of its underlying assumptions. 2. ed. Nova Iorque: Rowman \& Littlefield, 2006.
} 
Vê-se, então, que cada grupo está defendendo um estilo de vida que considera o mais correto e que suas concepções acerca do tema são diametralmente opostas. O que determinará a imposição de uma ou outra regra, nesta situação, e em todas as demais, serão os interesses pessoais, o empreendedorismo e a publicidade, em interação com a complexidade das situações.

Entretanto, destaca Becker que nesse processo de constituição de crimes há também regras criadas por uma lógica invertida. Elas nascem com base em interesses pessoais e apenas depois são racionalizadas, como se fossem derivadas de um valor geral. Crê também que há atos que são impostos para apenas depois virarem regras ${ }^{422}$.

Como decorrência lógica do processo de criminalização primária, em continuidade à formulação de uma nova norma segue a necessidade de sua imposição por meio de agências especializadas. É, pois, com o estabelecimento desses órgãos de imposição da lei que a cruzada moral torna-se institucionalizada ${ }^{423}$.

Conforme foi aventado no item acima, quanto mais fases do processo de criminalização o indivíduo percorrer, proporcionalmente menores serão as chances de ele irromper o ciclo vicioso que desperta do sistema penal.

Em razão disso, tem-se que os programas de prevenção primária da criminalidade, ou seja, aqueles que atacam as raízes do ingresso no sistema, são mais eficazes do que os de prevenção secundária ou terciária, e por isso devem ser mais estimulados ${ }^{424}$.

A proposta do labelling approach para evitar um primeiro contato com o sistema formalizado de controle refere-se à descriminalização de condutas, ou seja, à retirada da previsão de determinados comportamentos da lei penal incriminadora, especialmente os relativos aos delitos sem vítimas e aqueles que apenas afrontam a moralidade dos indivíduos, tais como o uso de drogas, a pornografia e os jogos de azar.

É essa, pois, a primeira fase do processo de criminalização. As normas criminalizantes são estabelecidas em forma de regramentos genéricos, programáticos, os

${ }^{422}$ BECKER, Howard S. Outsiders: studies in the sociology of deviance. Nova Iorque: The Free Press, 1997.

${ }^{423}$ BECKER, Howard S. Outsiders: studies in the sociology of deviance. Nova Iorque: The Free Press, 1997. Note-se, que os teóricos do labelling approach negam a existência de consenso sobre as normas, esmiúçam seu processo de implementação e esboçam os mecanismos do poder, mas não se detêm na análise de suas raízes sócio-políticas, omissão pela qual foram bastante criticados. Cf. CASTRO, Lola Aniyar de. Criminologia da reação social. Tradução de Ester Kosovski. Rio de Janeiro: Forense, 1983.

${ }^{424}$ GARCÍA-PABLOS DE MOLINA, Antonio. La prevención del delito: reflexiones en torno a la denominada 'prevención situacional'. In: José Luis Guzmán Dalbora (Coord.) El penalista liberal. Buenos Aires: Hammurabi, 2004. 
quais, para sua aplicação, utilizam-se de um instrumental jurídico definido, de regras de aplicação, que serão viabilizadas pelas agências de criminalização secundária.

\subsubsection{Criminalização secundária}

No ordenamento jurídico brasileiro a tarefa de aplicar e dar cumprimento à lei penal cabe às Polícias e à Justiça. Esse processo, que culmina na captura do sujeito pelo sistema penal, é que encerra o mecanismo da criminalização secundária.

Assim, ele consiste no exercício da ação punitiva sobre pessoas concretamente determinadas, já selecionadas no primeiro filtro da criminalização primária.

Trata-se ainda da macroperspectiva explicativa do labelling approach, tal qual a criminalização primária, cujo objetivo também é o de verificar como se define numa sociedade o que é a criminalidade.

Visando a justificar sua existência, as agências a serviço do controle formal esforçam-se por demonstrar que o problema que elas devem combater existe e que sua ação é necessária, o que as auxilia na tarefa de alcançar respeito dos cidadãos. Desse modo, grande parte de seu trabalho consiste não apenas em impor as normas, mas em coagir os demais a respeitar sua tarefa e existência, já que querem elas fazer-se presentes e necessárias $^{425}$.

A violação de uma norma não determina, automaticamente, o início dos mecanismos repressivos nela contidos, sendo o desencadeamento da ação do sistema penal "seletivo, e seletivo diferentemente entre os tipos de pessoas, em épocas diferentes, e em diferentes situações" ${ }^{426}$.

Trata-se, certamente, de processo bastante arbitrário, já que

a sociedade tende a criminalizar as pessoas vulneráveis no seu todo: vulneráveis no seu ser econômico, social, cultural e psíquico. A sociedade precisa dessas pessoas frágeis, para, às suas custas, garantir o respeito à legalidade, provar o rigor da lei e ostentar todos os 'poderes do rei' ${ }^{427}$.

Nesse diapasão, evidencia-se que os fatores extralegais podem ser mais importantes do que os legais na escolha dos capturados pelo sistema.

\footnotetext{
${ }^{425}$ BECKER, Howard S. Outsiders: studies in the sociology of deviance. Nova Iorque: The Free Press, 1997.

${ }^{426}$ BECKER, Howard S. Outsiders: studies in the sociology of deviance. Nova Iorque: The Free Press, 1997. p. 133.

${ }^{427}$ SÁ, Alvino Augusto de. Algumas ponderações acerca da reintegração social dos condenados à pena privativa de liberdade. Disponível em <www.eap.sp.gov. br/ponderacoes.pdf>. Acesso em 25 mai. 2007. p. 10 .
} 
Ademais, "em razão da escassíssima capacidade operacional das agências executivas, a impunidade é sempre a regra e a criminalização secundária, a exceção" ${ }^{428}$.

Ainda no que toca a esse aspecto, afirmam Zaffaroni et al. que

a disparidade entre a quantidade de conflitos criminalizados que realmente acontecem numa sociedade e aquela parcela que chega ao conhecimento das agências do sistema é tão grande e inevitável que seu escândalo não logra ocultar-se na referência tecnicista a uma cifra oculta ${ }^{429}$.

Não se pode olvidar também que influencia no modo pelo qual exercem suas funções e lidam com sua clientela o entendimento que as agências de controle têm acerca das teorias de causação do comportamento humano. Muitas delas compreendem a opção pela prática criminosa como um fenômeno individual e por isso cometem o equívoco de tratar delinquências situacionais ou sistemáticas como se meramente individuais fossem ${ }^{430}$.

Adicione-se a isso o fato de existir o controle social punitivo institucionalizado e, ao lado dele, um outro, não institucionalizado, levado a cabo por alguns ou por todos os seus servidores por meio de métodos não institucionalmente admitidos, tais como técnicas de tortura e de interrogatório ilícito. Ademais, os diferentes segmentos do sistema penal podem operar de uma forma empírica técnica ou não técnica, apesar de sempre tentarem demonstrar que utilizam modos operativos mais tecnificados do que realmente fazem ${ }^{431}$, o que se reflete no produto final de seu trabalho.

Fato é que não se pode deixar de ter em vista que toda a atuação dos órgãos do sistema penal é permeada pelo respeito a um second code não estabelecido formalmente. As normas jurídicas, mencionadas no excerto anterior, podem ser denominadas de genéricas, uma vez que representam regramentos sociais gerais. Todavia, existem ao lado delas normas ou práticas interpretativas - second codes -, as quais, estando na base da interação social, determinam o sentido da estrutura social. Sack as nomeia, respectivamente, de regras e metarregras do Direito Penal e explica que estas são

\footnotetext{
${ }^{428}$ ZAFFARONI, Eugenio Raúl et al. Direito Penal Brasileiro. 2. ed. Rio de Janeiro: Revan, 2003. v. 1. p. 45. ${ }^{429}$ ZAFFARONI, Eugenio Raúl et al. Direito Penal Brasileiro. 2. ed. Rio de Janeiro: Revan, 2003. v. 1. p. 44. ${ }^{430}$ LEMERT, Edwin M. Social Pathology: a systematic approach to the theory of sociopathic behavior. 1. ed. Nova Iorque: Toronto: Londres: McGraw-Hill, 1951. Para Lemert a desviação situacional é aquela na qual o indivíduo realiza uma prática ilícita em decorrência do impacto de situações externas que o atingem, ou seja, antes desse momento o sujeito dirigia-se a observância das normas, mas a ocorrência de fato prejudicial fez com que ele mudasse seu comportamento. Em contrapartida, a desviação sistemática apresenta-se quando desenvolvida subcultura e racionalização próprias para justificar a conduta tida como ilegal. Trata-se de um novo sistema organizacional de valores e moral não condizente com os aceitos pela maioria. Cf. LEMERT, Edwin M. Social Pathology: a systematic approach to the theory of sociopathic behavior. 1. ed. Nova Iorque: Toronto: Londres: McGraw-Hill, 1951.

${ }^{431}$ ZAFFARONI, Eugenio Raúl. Criminología: aproximación desde un margen. Colômbia: Temis, 1993.
} 
regramentos do sistema social que direcionam toda a filtragem feita pelos sistemas de controle $^{432}$.

São elas, em última análise, que determinam a formação do grupo de desviantes e justificam a discrepância entre as criminalidades latente e perseguida.

Isso posto, por todas as razões acima expostas é que o processo de criminalização secundária pode ser visualizado graficamente como um funil, no qual, do montante total dos comportamentos ilícitos praticados, apenas alguns são capturados e processados pelo sistema $^{433}$.

A despeito da similaridade de participarem da segunda fase do processo criminalizador, cada órgão encarregado dessa função o faz de maneira peculiar, em decorrência da atividade específica por eles realizada. Levando-se em consideração esse fator, mister destacar o papel que desenvolvem a Polícia e a Magistratura no processo de criminalização secundária.

A Polícia pode ser definida como "a agência diretamente responsável pela proteção da comunidade e a qual se torna o alvo para o descontentamento geral com o cumprimento da lei" ${ }^{434}$.

Sendo a primeira instância a lidar com a suposta criminalidade, é sua a principal seleção de quem serão as pessoas criminalizadas e das vítimas merecedoras de proteção.

Sua forma de atuação depende da relação que estabelece com o infrator, com a vítima, da sua estrutura organizacional, das políticas que adota, bem como da concepção que tenha de sua função ${ }^{435}$.

Os policiais perseguem precipuamente os sujeitos cujas características identificamse com a dos seus principais clientes; têm tendência a atuar de modos distintos tendo em vista aspectos pessoais e de comportamento da vítima; agem mais rigorosamente na

${ }^{432}$ BARATTA, Alessandro. Criminologia crítica e crítica do direito penal: introdução à sociologia do direito penal. Tradução de Juarez Cirino dos Santos. 2. ed. Rio de Janeiro: Freitas Bastos, 1999. Sack foi expoente alemão do labelling approach de maior destaque, cujo pensamento foi fortemente influenciado pelo interacionismo.

${ }^{433}$ GROSNER, Marina Quezado. A seletividade do sistema penal na jurisprudência do Superior Tribunal de Justiça: o trancamento da criminalização secundária por decisões em habeas corpus. São Paulo: IBCCRIM, 2008. Nesse diapasão, cabe referir-se a existência de uma cifra negra ou oculta da criminalidade que representa a discrepância entre os índices da criminalidade real - dos crimes verdadeiramente praticados em determinado período de tempo e local - e da aparente - fração dos ilícitos conhecida pelos órgãos do sistema penal.

${ }^{434}$ LEMERT, Edwin M. Social Pathology: a systematic approach to the theory of sociopathic behavior. 1. ed. Nova Iorque: Toronto: Londres: McGraw-Hill, 1951.p. 311.

${ }^{435}$ LARRAURI, Elena. La herencia de la criminología crítica. 2. ed. Madri: Siglo veintiuno de España, 2000. Sobre o tema ver também: VOLD, George B.; BERNARD, Thomas J. Theoretical Criminology. 3. ed. Nova Iorque: Oxford University Press, 1986. 
persecução de alguns crimes quando há delegacia especializada no combate a determinado gênero de ilícitos; entre outros fatores.

É evidente que o volume de trabalho de um policial é muito grande e em razão disso ele estabelece prioridades na execução de sua função. Assim, ele acaba utilizando-se de critérios próprios, não dispostos normativamente, para desenvolver sua atividade. E no exercício de sua tarefa ele mesmo cria os desviantes de modo seletivo, podendo a pessoa ser por ele assim taxada devido a fatores estranhos ao seu comportamento ${ }^{436}$.

Nesse diapasão,

os agentes do controle social formal (polícia, tribunais, etc.) não são meras 'correias de transmissão' da vontade geral, senão 'filtros' a serviço de uma sociedade desigual que, através dos mesmos, perpetua suas estruturas de dominação e potencializa as injustiças que a caracterizam. Em conseqüência, a população penitenciária, subproduto final do funcionamento discriminatório do sistema legal, não pode estimar-se representativa da população criminal real ${ }^{437}$.

Essas regras extralegais de ação policial dirigem-se especialmente às minorias étnicas e raciais e aos economicamente fracos, grupos cujas violações geram menos repercussões sociais. ${ }^{438}$.

Desse modo, tem como seu principal critério seletivo o estereótipo do criminoso, razão pela qual se verifica certa uniformidade na população capturada pelo sistema. Essas características comuns - componentes de classe, de gênero, estético - são causas da criminalização que podem tornar-se causas do delito se o sujeito porventura assumir o papel vinculado ao estereótipo ${ }^{439}$.

Consoante se mencionou, além de variar de acordo com as características pessoais ou sociais de seu autor, o exercício da repressão também muda conforme a natureza do crime $^{440}$. Certamente não é seu alvo principal a criminalidade dos poderosos, mas sim a tradicional, muito menos danosa socialmente.

Fica evidente, assim, a discricionariedade desse órgão no que concerne à seleção das investigações as quais procederão, sendo certo que "a polícia é não só a instância que

\footnotetext{
${ }^{436}$ BECKER, Howard S. Outsiders: studies in the sociology of deviance. Nova Iorque: The Free Press, 1997.

${ }^{437}$ GARCÍA-PABLOS DE MOLINA, Antonio. La aportación de la Criminología. Eguzkilore. Cuaderno del Instituto Vasco de Criminología, San Sebastián, n. 3, p. 79-94, dez. 1989. p. 83.

${ }^{438}$ LEMERT, Edwin M. Social Pathology: a systematic approach to the theory of sociopathic behavior. 1. ed. Nova Iorque: Toronto: Londres: McGraw-Hill, 1951.

${ }^{439}$ ZAFFARONI, Eugenio Raúl et al. Direito Penal Brasileiro. 2. ed. Rio de Janeiro: Revan, 2003. v. 1.

${ }^{440}$ LEMERT, Edwin M. Social Pathology: a systematic approach to the theory of sociopathic behavior. 1. ed. Nova Iorque: Toronto: Londres: McGraw-Hill, 1951.
} 
processa o caudal mais volumoso de deviance, mas também o que o faz em condições de maior discricionariedade" ${ }^{441}$.

Finalizada sua atividade, pode ter lugar a fase judicial da persecução penal, na qual o juiz de direito é peça fundamental.

Cabe a ele, em última análise, o recrutamento final dos sujeitos que conformarão a massa de delinquentes em dada sociedade, o que se efetiva por meio da emissão de uma decisão condenatória, cujos efeitos são ainda piores dos que os provocados pela atuação policial. Isso porque ela implica a perda, ainda que provisória, dos direitos civis do condenado e em seu afastamento e isolamento da sociedade ${ }^{442}$.

Entretanto, a despeito da significação que representa sua ingerência na vida de um condenado, não se pode deixar de observar que se trata de um poder mitigado pela ação policial, uma vez que "o poder punitivo é exercido bem mais pela polícia, limitando-se as agências judiciais a resolver os poucos casos selecionados pelas agências policiais" "443. É, pois, a polícia que faz a mais importante seleção qualitativa dos casos a serem criminalizados, restringindo-se os magistrados a dar continuidade ao processo criminalizante ou interrompê-lo.

Os teóricos do labelling approach não creem na imparcialidade dos magistrados, uma vez que eles depositam em sua atividade diária e reproduzem em suas sentenças as crenças e os preceitos do grupo social do qual advém ${ }^{444}$.

Em razão disso, suas sentenças, por vezes, representam discursos jurídicos legitimantes da seleção que desejam realizar.

De qualquer modo, não é difícil perceber que a semelhança entre os que estão sendo julgados e seus julgadores desperta nestes uma maior benevolência em relação aos crimes praticados. Christie ilustra de forma brilhante essa assertiva ${ }^{445}$.

${ }^{441}$ DIAS, Jorge de Figueiredo; ANDRADE, Manuel da Costa. Criminologia: o homem delinqüente e a sociedade criminógena. 2 reimp. Coimbra: Coimbra Editora, 1997. p. 443.

${ }^{442}$ LEMERT, Edwin M. Social Pathology: a systematic approach to the theory of sociopathic behavior. 1. ed. Nova Iorque: Toronto: Londres: McGraw-Hill, 1951.

${ }^{443}$ GROSNER, Marina Quezado. A seletividade do sistema penal na jurisprudência do Superior Tribunal de Justiça: o trancamento da criminalização secundária por decisões em habeas corpus. São Paulo: IBCCRIM, 2008. p. 62.

${ }^{444}$ SELLIN, Thorsten. Le sociologue et le problème du crime. Revue de Science Criminelle et de Droit Penal Comparé, Paris, n.4, p. 527-539, oct.ldec. 1950.

${ }^{445}$ CHRISTIE, Nils. El delito no existe. In: BAIGÚN, David et al. Estudios sobre Justicia Penal. Buenos Aires: Del Puerto, 2005. 
Conta ele que após o término da Segunda Grande Guerra um homem foi processado por haver colaborado com o regime nazista. Tratava-se de um antigo Ministro da Cultura que havia se unido ao gabinete nazista de Vidkun Quisling.

Esse homem havia sido condenado à pena de morte, razão pela qual recorreu à Corte Suprema alemã. Dia após dia o cidadão era escoltado à sala de audiências. Apresentava-se pálido, triste, cansado, maltrapilho, com uma desgastada vestimenta que costumava ser utilizada pelos magistrados de outrora, mas com um excelente vocabulário.

Por sua educação, como advogado que era, assemelhava-se aos seus julgadores, podendo inclusive ter sido um deles, se não houvesse optado pela participação num sistema político diferente.

Ao final de seu processo, o acusado acabou tendo sua pena de morte substituída pela prisão perpétua, a despeito de ter efetivamente atuado na reprodução do regime.

Um dos participantes do processo, cuja identidade não é revelada por Christie, insiste que o que o salvou da execução letal foi sua aparição constante no tribunal.

Não havia dúvidas de que seus atos eram delituosos. Mas ele se aproximou tanto do padrão de seus julgadores, de seus iguais, que estes não conseguiram enxergá-lo como um cruel criminoso que merecia morrer.

Portanto, dadas as vicissitudes relatadas acerca desse imparcial mecanismo de criminalização, o labelling approach desenvolveu propostas na tentativa de barrá-lo, evitando, assim, que suas consequências deletérias se produzam.

Dentre elas destacam-se a diversão, a desinstitucionalização e o due process.

A diversão consiste em se ofertar uma resposta diversa - daí o seu nome - ao ilícito praticado, evitando, dessa forma, o contato do indivíduo com a Justiça Criminal. Trata-se de tentar encontrar respostas menos impactantes ao crime, inclusive com o redirecionamento de algumas infrações a instituições desvinculadas do sistema penal, visando a evitar que o sujeito se depare com condições favoráveis à geração da desviação secundária.

A desinstitucionalização ou descarcerização versa sobre o estímulo à aplicação de reprimendas diversas das cumpridas em instituições fechadas de privação de liberdade, reservando estas apenas aos autores de crimes mais graves. 
O due process, por sua vez, refere-se ao fortalecimento das garantias legais, bem como à incitação do respeito às regras do sistema, evitando, desse modo, a discricionariedade da atuação em observância às metarregras.

Entretanto, não sendo esse processo interpelado nessa última oportunidade, podem ser desencadeadas profundas transformações no sujeito que o atravessou.

\title{
2.4.3. Criminalização terciária
}

$\mathrm{Na}$ criminalização terciária o foco de estudo são as consequências negativas do contato do sujeito com as agências criminalizantes, uma vez que se enfatizam as mudanças que a experiência pode provocar nele, em sua autopercepção e em sua forma de encarar a sociedade.

Trata-se da microperspectiva de explicação do labelling approach, na qual, ressaltando o plano psicológico-social, analisa-se como se transforma em criminoso aquele que assim é tratado e definido.

De acordo com a teorização proposta, toda a interação com o sistema de controle social formal gera consequências negativas ao sujeito, as quais se agravam quando desse contato resulta a aplicação de uma sanção, mormente a privativa de liberdade. Nesse sentido, tem-se que

\begin{abstract}
a instituição penal está em uma situação análoga a do rei Midas. Tudo o que ele tocava convertia-se em ouro, e, como todos sabemos, morreu de fome. Muito do que a polícia toca e tudo o que a prisão toca, converte-se em delitos e delinqüentes, e desvanecem-se as interpretações alternativas de atos e atores ${ }^{446}$.
\end{abstract}

Em decorrência desse contato é que se atribui a etiqueta de desviado ao sujeito, iniciando sua estigmatização, a qual pode dar origem à desviação secundária e ao desenvolvimento de uma carreira criminal.

Isso posto, mister a análise mais acurada desta transformação que ocorre no indivíduo.

${ }^{446}$ CHRISTIE, Nils. El delito no existe. In: BAIGÚN, David et al. Estudios sobre Justicia Penal. Buenos Aires: Del Puerto, 2005. p. 557. 
2.4.3.1. A atribuição da etiqueta de desviado e o processo de estigmatização

A captura do sujeito pelo sistema de controle social faz com que lhe seja atribuída uma etiqueta, um rótulo de desviado, e com que ele seja encarado pela sociedade nos termos de sua nova qualificação.

Uma etiqueta criminal é um elemento de identificação. Sendo assim, "a atribuição da etiqueta de delinquente a um sujeito que cometeu um ato desviado, tem o efeito de situá-lo em uma categoria precisa e, portanto, de que todos o considerem como um ser aparente $^{, 447}$.

Mais do que isso, ela não significa apenas que o sujeito violou a lei, mas implica a degradação pública de seu caráter, uma vez que é o primeiro passo no desencadeamento da estigmatização da pessoa.

O processo de estigmatização é de importância indiscutível para a teoria, já que toda a investigação do labelling approach gravita em torno de sua problematização, seja como variável dependente ou independente.

No primeiro caso, reconduz-se a análise dos critérios pelos quais determinadas pessoas são capturadas pelo sistema penal em detrimento de outras. Ou seja, trata-se dos processos de criminalização que determinam a clientela do sistema e seus estigmatizados $^{448}$.

No segundo, trata-se fundamentalmente da adscrição do status de delinquente sobre a dinâmica de formação da identidade, do início das carreiras criminais e, consequentemente, da desviação secundária ${ }^{449}$. Nessa hipótese, a teoria parte do estigma para explicar a reincidência, a reiteração da conduta desviada e a gênese do crime.

Portanto, o estigma tanto pode ser instrumento de estereotipia dos delinquentes e desviantes, como gerador de ulterior delinquência e desvio ${ }^{450}$.

É, pois, nesse seu segundo aspecto que ele passa a ser analisado a partir de agora ${ }^{451}$.

\footnotetext{
${ }^{447}$ BARBERO SANTOS, Marino. La delincuencia juvenil en España: imagen y realidad. Doctrina Penal: Teoría y Práctica en las Ciencias Penales, Buenos Aires, v. 6, n. 21-24, p. 417-436, 1983. p. 431.

${ }^{448}$ Perspectiva já analisada nos itens 2.4.1. e 2.4.2 do presente trabalho.

${ }^{449}$ DIAS, Jorge de Figueiredo; ANDRADE, Manuel da Costa. Criminologia: o homem delinqüente e a sociedade criminógena. 2 reimp. Coimbra: Coimbra Editora, 1997. Estes conceitos - desviação secundária e carreiras criminais - serão estudados neste item e no subsequente, bem como no capítulo 4 do presente trabalho.

${ }^{450}$ AMAR, Ayush Morad. Temas de Criminologia. São Paulo: Resenha Universitária, 1982. v. II.

${ }^{451}$ É na análise do estigma e das consequências que a partir dele se iniciam que se verifica a maior influência exercida pelo interacionismo sobre o labelling approach.
} 
No Antigo Regime os castigos eram aplicados, e inclusive gravados, no corpo do condenado, como instrumento de identificação acessível a qualquer um que o avistasse. Assim,

os detentos, e também os doentes, mulheres sem família, mendigos, loucos e crentes de outras religiões, costumavam ter o nariz cortado, ou uma orelha, braço ou perna, ou, em todo caso, uma tatuagem com uma letra ou desenho que imediatamente permitisse saber 'quem' eles eram ${ }^{452}$.

Mesmo antes disso já se costumava gravar os escravos com marcas de ferro, com o objetivo de identificá-los no caso de eventual fuga.

Esses eram os seus estigmas.

Hodiernamente a expressão carrega um significado bastante semelhante, com a diferença de que é mais aplicada à própria desgraça do que à evidência corporal do sujeito. Trata-se de um mecanismo a priori de identificação do indivíduo, que permite seu conhecimento sem a necessidade de que um contato mais do que superficial seja com ele realizado, tendo em vista o enquadramento a categorizações de antemão estabelecidas pela sociedade $^{453}$.

É um "atributo derrogatório imputado à imagem social de um indivíduo ou grupo e visto como instrumento de controle social” ${ }^{\prime 454}$.

Nesse sentido,

o estigma envolve não tanto um conjunto de indivíduos concretos que podem ser divididos em duas pilhas, a de estigmatizados e a de normais, quanto um processo social de dois papeis no qual cada indivíduo participa de ambos, pelo menos em algumas conexões e em algumas fases da vida. $\mathrm{O}$ normal e o estigmatizado não são pessoas, e sim perspectivas que são geradas em situações sociais durante os contatos mistos, em virtude de normas não cumpridas que provavelmente atuam sobre o encontro ${ }^{455}$.

A despeito de ser utilizado como um atributo depreciativo o estigma não é ruim em si, mas serve para diferenciar negativamente um sujeito de determinado grupo comparado. Serve, pois, para reforçar a normalidade deste.

O negativamente estigmatizado é encarado como pessoa que está inabilitada para a aceitação social plena; um indivíduo que poderia ter sido facilmente recebido na relação

\footnotetext{
452 ANITUA, Gabriel Ignacio. Histórias dos pensamentos criminológicos. Tradução de Sérgio Lamarão. Rio de Janeiro: Revan, 2008. p. 104.

${ }^{453}$ GOFFMAN, Erving. Estigma: notas sobre a manipulação da identidade deteriorada. Tradução de Márcia Bandeira de Mello Leite Nunes. 4. ed. Rio de Janeiro: LCT, 1988.

${ }^{454}$ AMAR, Ayush Morad. Temas de Criminologia. São Paulo: Resenha Universitária, 1982. v. II. p. 75.

${ }^{455}$ GOFFMAN, Erving. Estigma: notas sobre a manipulação da identidade deteriorada. Tradução de Márcia Bandeira de Mello Leite Nunes. 4. ed. Rio de Janeiro: LCT, 1988. p. 149.
} 
social cotidiana possui um traço que pode se impor à atenção e afastar aqueles que ele encontra, destruindo a possibilidade de conhecimento de outros atributos seus.

Assim, com a estigmatização, o processo de interação que atribui a etiqueta entra numa fase qualitativamente diversa, uma vez que o estigmatizado recebe junto com o estigma um status social negativo, o qual limita sensivelmente suas possibilidades de atuar e faz verossímil todas as ações negativas imputadas desde o começo ao sujeito ${ }^{456}$.

Por essa razão é que ele se esforça por esconder sua condição na interação social, representando um papel condizente com o qual ele almeja ser tratado.

Seu estigma fornece uma informação destrutiva e qualquer descuido durante sua representação poderá desacreditar, romper ou tornar inútil a impressão que o sujeito estimula. É a revelação, no caso do desviante, de seu segredo íntimo e indevassável ${ }^{457}$.

A imagem pública de um indivíduo é construída com base em alguns atos seus, de conhecimento dos demais, os quais são considerados em sua extensão máxima, conformando assim um retrato global de dito sujeito ${ }^{458}$.

Isso faz com que ocorra uma mudança gradual da definição de um ato como malvado para a definição do sujeito que o praticou como tal. Todas suas características pessoais são absorvidas por sua nova identidade negativa. Para a comunidade o sujeito tornou-se um ser humano mau e seus atos são encarados com suspeição. Não apenas os atos presentes, mas também os passados, uma vez que o estigma autoriza seja feita uma interpretação retrospectiva das condutas do estigmatizado.

Outrossim, estabelecida essa reputação, todas as agências, inconscientemente, juntam-se para mantê-la ${ }^{459}$.

Fato é que "o jovem delinqüente torna-se mau porque ele é definido como mau e porque ele não é acreditado se ele é bom" "460. É ele impedido de demonstrar que possui

456 RÜTHER, Werner. La criminalidad (o el "delincuente") a traves de las definiciones sociales (o etiquetamiento). Doctrina Penal: Teoría y Práctica en las Ciencias Penales, Buenos Aires, v. 1, n. 1-4, p. 749-764, 1978.

${ }^{457}$ GOFFMAN, Erving. A representação do eu na vida cotidiana. Tradução de Maria Célia Santos Raposo. Petrópolis: Vozes, 1975. Para o autor, o segredo indevassável é aquele que se refere a fatos incompatíveis com a imagem que o sujeito pretende manter perante o público, enquanto que o íntimo é o que marca o indivíduo como membro de um grupo e contribui para que ele se sinta diferente dos que dele não participam e não conhecem essa condição. Cf. GOFFMAN, Erving. A representação do eu na vida cotidiana. Tradução de Maria Célia Santos Raposo. Petrópolis: Vozes, 1975.

${ }^{458}$ GOFFMAN, Erving. Estigma: notas sobre a manipulação da identidade deteriorada. Tradução de Márcia Bandeira de Mello Leite Nunes. 4. ed. Rio de Janeiro: LCT, 1988.

${ }^{459}$ TANNEMBAUM, Frank. Crime and the community. Nova Iorque: Columbia University Press, 1951.

${ }^{460}$ TANNEMBAUM, Frank. Crime and the community. Nova Iorque: Columbia University Press, 1951. p. 17-18. 
atributos favoráveis, já que o ato negativo por ele praticado cola-se à sua identidade e passa a ser a única característica nele vislumbrada.

Importante ressaltar, entretanto, que a imposição de uma etiqueta durante a interação depende de um processo de negociação, em que se identificam relações de poder, tal qual ocorre quando da escolha de um comportamento a ser criminalizado ou de um sujeito cooptado pelas agências penais. Em outros termos, as etiquetagens sociais são inconstantes.

Isso porque a reação social que precede a nova qualificação não é objetiva nem depende meramente da gravidade ou da natureza do ato praticado. É ela arbitrária, como o é sua consequência maior - a atribuição da etiqueta indesejável a alguém ${ }^{461}$. A discrepância na qualificação negativa de atos praticados por ricos e pobres, brancos e negros, nacionais ou estrangeiros, por exemplo, deixa claro que o processo de etiquetamento não se desenvolve ao acaso, mas sim que cumpre funções sociais implícitas ${ }^{462}$.

$\mathrm{O}$ fato de o indivíduo ter sido capturado pelos mecanismos repressivos do Estado provoca diferentes reações, dependendo do grupo considerado. Os criminosos o tratarão como um infrator fracassado, já que ele falhou na tarefa de se proteger do sistema formal de controle. Ademais, pode ser que, devido a essa sua inabilidade, ele deixe de aspirar confiança nos demais, que podem se recusar a com ele realizar outras práticas ilícitas, temendo por sua segurança. Em contrapartida, o grupo dos não criminosos o encarará como uma pessoa indigna de confiança, em cujas palavras e atos não se deve acreditar ${ }^{463}$.

Ao tornar-se um presidiário, por exemplo, do ponto de vista da sociedade, o indivíduo passa a fazer parte integrante desse grupo de estigmatizados e a ser encarado como igual a todos eles. Isso decorre do fato de que "a natureza de uma pessoa, tal como ela mesma e nós a imputamos, é gerada pela natureza de suas filiais grupais" ${ }^{\text {464 }}$.

O ex-detento tem status e papel social implicitamente marginais. Ainda que se pregue que após "paga sua dívida com o Estado" pode ele voltar a participar da vida social em condições de igualdade, a realidade mostra a falácia dessa afirmação. É cediço que é

461 EINSTADTER, Werner J.; HENRY, Stuart. Criminological theory: an analysis of its underlying assumptions. 2. ed. Nova Iorque: Rowman \& Littlefield, 2006.

${ }^{462}$ LARRAURI, Elena. La herencia de la criminología crítica. 2. ed. Madri: Siglo veintiuno de España, 2000.

${ }^{463}$ LEMERT, Edwin M. Social Pathology: a systematic approach to the theory of sociopathic behavior. 1. ed. Nova Iorque: Toronto: Londres: McGraw-Hill, 1951.

${ }^{464}$ GOFFMAN, Erving. Estigma: notas sobre a manipulação da identidade deteriorada. Tradução de Márcia Bandeira de Mello Leite Nunes. 4. ed. Rio de Janeiro: LCT, 1988. p. 124. 
ele marginalizado e discriminado, sendo por isso impedido de reconstruir sua vida, especialmente nos aspectos social e econômico ${ }^{465}$.

O estigma, em seu caso, decorrente de maus antecedentes morais, parece assumir uma função social implícita, além da explícita ínsita a todo estigma, que é a de amealhar apoio para a sociedade entre aqueles que não são apoiados por ela. Essa função oculta é a de funcionar como um meio de controle social formal ${ }^{466}$.

Esses estigmatizados são barrados da participação social, o que faz com que eles não consigam inserir-se em um grupo social dito "normal".

Em decorrência disso, contando com o fato de ter um estigma não aparente, o expresidiário esforça-se por encobri-lo, para evitar, com isso, manifestações sociais negativas, o que faz com que ele assuma uma vida dupla ${ }^{467}$.

Nesse diapasão relata Goffman que quando o estigma de um indivíduo se instaura nele durante a estadia numa
instituição, e quando a instituição conserva sobre ele uma influência
desacreditadora durante algum tempo após a sua saída, pode-se esperar o
nascimento de um ciclo especifico de encobrimento ${ }^{468}$.

Esse se inicia porque como o indivíduo "ganhou" seu estigma em um momento avançado de sua vida ele sabe exatamente como os "normais" lidam com esses sujeitos inferiorizados e sobreviver psicologicamente a sua nova situação pode ser bastante difícil e traumatizante.

A conduta dos seres considerados normais perante o indivíduo estigmatizado é discriminatória e excludente, utilizando-se ainda de termos pejorativos para referenciá-lo. Assim, visando a adequar-se ao padrão de normalidade social, o estigmatizado pode esforçar-se para ser aceito pelo grupo; em outros casos, em contrapartida, pode ele assumir uma postura de fuga da realidade que é a ele tão desfavorável ou comportar-se de modo combativo.

\footnotetext{
${ }^{465}$ LEMERT, Edwin M. Social Pathology: a systematic approach to the theory of sociopathic behavior. 1. ed. Nova Iorque: Toronto: Londres: McGraw-Hill, 1951.

${ }^{466}$ GOFFMAN, Erving. Estigma: notas sobre a manipulação da identidade deteriorada. Tradução de Márcia Bandeira de Mello Leite Nunes. 4. ed. Rio de Janeiro: LCT, 1988.

${ }^{467}$ Goffman explica que todos os que optam, em sua interação social, por encobrir um estigma que lhe é desfavorável assumem uma vida dupla que pode ser qualificada como simples ou dupla. Na simples há sujeitos que realmente conhecem bem o indivíduo e sua trajetória de vida e outros que apenas acreditam conhecê-lo. Já na dupla vida dupla o sujeito adota duas formas de vida diversas, sendo que um grupo desconhece a outra. Cf. GOFFMAN, Erving. Estigma: notas sobre a manipulação da identidade deteriorada. Tradução de Márcia Bandeira de Mello Leite Nunes. 4. ed. Rio de Janeiro: LCT, 1988.

${ }^{468}$ GOFFMAN, Erving. Estigma: notas sobre a manipulação da identidade deteriorada. Tradução de Márcia Bandeira de Mello Leite Nunes. 4. ed. Rio de Janeiro: LCT, 1988. p. 105.
} 
Nesse sentido, "a pessoa estigmatizada algumas vezes vacila entre o retraimento e a agressividade, correndo de uma para a outra, tornando manifesta, assim, uma modalidade fundamental na qual a interação face-a-face pode tornar-se muito violenta" 469 .

Argyle explica essa relação que envolve o sujeito estigmatizado e suas interações. $\mathrm{Na}$ vida cotidiana as pessoas categorizam umas as outras e respondem a essa categorização com diferentes tipos de interação, a depender de seu conteúdo favorável ou desfavorável. Sendo esse fator comum, o indivíduo aprende a prever a qualificação que receberá e se ver nesses termos, no que se denomina sua autoimagem, representativa de como ele se percebe.

Ocorre que essa categorização pode ser negativa ou positiva, de maior ou menor prestígio, o que também é previsto pelo sujeito e torna-se sua autoestima, extensão em que uma pessoa tem atitudes favoráveis em relação a si mesma, baseada nas reações dos outros.

Esses processos cognitivos tornam-se determinantes das interações sociais, uma vez que a autoimagem só pode ser mantida se os outros a aceitam e reagem a ela de maneira apropriada $^{470}$.

Assim, como ápice de todo esse processo, a reação social adversa gerada pelo estigma pode transformar a concepção que o indivíduo tem de si próprio. Não raro ele torna-se autodepreciativo e desenvolve um auto-ódio.

Não se enxerga, num primeiro momento, portador dos caracteres a ele atribuídos. Assim, quando conhecida ou manifesta uma discrepância entre as identidades reais e virtuais, ela estraga a identidade social, afastando o indivíduo da sociedade e de si mesmo, tornando-o uma pessoa desacreditada frente a um mundo não receptivo ${ }^{471}$.

Em outros termos,

a situação especial do estigmatizado é que a sociedade lhe diz que ele é um membro do grupo mais amplo, o que significa que é um ser humano normal, mas também que ele é, até certo ponto, 'diferente', e que seria absurdo negar essa diferença. A diferença, em si, deriva da sociedade, porque, em geral, antes que

\footnotetext{
${ }^{469}$ GOFFMAN, Erving. Estigma: notas sobre a manipulação da identidade deteriorada. Tradução de Márcia Bandeira de Mello Leite Nunes. 4. ed. Rio de Janeiro: LCT, 1988. p. 27.

${ }^{470}$ ARGYLE, Michael. A interação social: relações interpessoais e comportamento social. Tradução de Márcia Bandeira de Mello Leite Nunes. Rio de Janeiro: Zahar, 1976.

${ }^{471}$ GOFFMAN, Erving. Estigma: notas sobre a manipulação da identidade deteriorada. Tradução de Márcia Bandeira de Mello Leite Nunes. 4. ed. Rio de Janeiro: LCT, 1988. Pode-se definir a identidade social real como a representação das categorias e atributos que uma pessoa realmente mostra ter e a identidade social virtual como as categorias e atributos que a sociedade, de antemão, imputa ao sujeito. Cf. GOFFMAN, Erving. Estigma: notas sobre a manipulação da identidade deteriorada. Tradução de Márcia Bandeira de Mello Leite Nunes. 4. ed. Rio de Janeiro: LCT, 1988.
} 
uma diferença seja importante ela deve ser coletivamente conceptualizada pela sociedade como um todo ${ }^{472}$.

Por isso é comum que o estigmatizado tente esconder sua condição. Porém, revelada a discrepância entre a imagem do sujeito, sustentada por ele próprio, e a que ele realmente ostenta, mas tenta esconder, reflexos são sentidos em três níveis da realidade social: a interação social, a estrutura social e a personalidade do indivíduo.

Do ponto de vista da interação social, identificado o papel discrepante, pode-se dar ensejo a uma situação confusa e embaraçosa, de desorganização da própria ação em curso. No tocante à estrutura social, vale dizer que as unidades sociais mais amplas ficam comprometidas quando ocorre a ruptura da representação, já que isso afeta as instituições a que o sujeito diz pertencer, tendo em vista que a plateia tem grande tendência a encará-las tendo o sujeito como seu representante. Finalmente a personalidade do indivíduo é afetada pela ruptura, pois as concepções de si mesmo em torno das quais construiu sua personalidade podem ficar desacreditadas ${ }^{473}$.

Porém, é quando o rótulo negativo é aceito e incorporado pelo estigmatizado que o processo de criminalização atinge o ponto máximo de seu ciclo deletério. Trata-se da consubstanciação da desviação secundária que será a seguir analisada.

\subsubsection{Desviação secundária}

Conforme salientado no decorrer do presente capítulo, todo o processo de criminalização a que o indivíduo é submetido transforma um ato seu, que pode ter sido isolado em sua vida, no mais importante de sua existência. Por meio dessa conduta é que os demais passam a definir sua personalidade, sendo ele forçado a ajustar-se a essa nova etiqueta que lhe foi dada. Esse mecanismo pode dar-se de forma tão avassaladora que o autor do ato acaba por assumir para si e identificar-se com a identidade que lhe foi atribuída, num mecanismo de desviação secundária ${ }^{474}$.

Assim, a desviação secundária acaba sendo a resposta do sujeito à qualificação negativa que the foi imposta pela sociedade e da qual ele não conseguiu desvincular-se,

\footnotetext{
${ }^{472}$ GOFFMAN, Erving. Estigma: notas sobre a manipulação da identidade deteriorada. Tradução de Márcia Bandeira de Mello Leite Nunes. 4. ed. Rio de Janeiro: LCT, 1988. p. 134.

${ }^{473}$ GOFFMAN, Erving. A representação do eu na vida cotidiana. Tradução de Maria Célia Santos Raposo. Petrópolis: Vozes, 1975.

${ }^{474}$ TANNEMBAUM, Frank. Crime and the community. Nova Iorque: Columbia University Press, 1951.
} 
terminando por incorporar o papel que the foi imposto pelos demais. $O$ desviado secundário é alguém que se conforma com o retrato que a sociedade tem dele ${ }^{475}$.

Ocorre, pois, a cristalização da autoimagem de desviante em seguida à internalização das etiquetas estigmatizantes.

Nesse caso, o sujeito não praticará crimes porque esta é uma entre as várias opções de comportamento que ele poderia assumir, mas o fará porque o que ele se tornou faz dessa escolha a mais fácil e previsível entre todas as possíveis, uma vez que este é o ato mais condizente com o novo status que lhe foi atribuído socialmente e que ele, no sucesso da desviação secundária, incorporou.

O conceito de desviação secundária foi desenvolvido por Lemert em sua obra Social Pathology: a systematic approach to the theory of sociopathic behavior, datada de 1951. Para o sociólogo,

quando uma pessoa começa a empregar seu comportamento desviante ou um papel baseado sobre ele como um meio de defesa, ataque, ou ajustamento aos problemas públicos ou encobertos criados pela reação social a ele, sua desviação é secundária ${ }^{476}$.

Ela ocorre, pois, quando a reação social ao primeiro desvio é de tal monta que restringe, total ou parcialmente, as chances e as oportunidades para que o sujeito se engaje em atividades socialmente legitimadas ${ }^{477}$.

Fato é que

a resposta dramatizada e ritualizada à delinquiência desencadeia dois tipos de conseqüências, convergentes nos seus efeitos últimos. Em primeiro lugar e no plano dos outros significantes, potencia a distância social em relação ao delinqüente, estreitando a sua margem de oportunidades legítimas e induzindo a procura de oportunidades ilegítimas [...]. Em segundo lugar e no que respeita ao delinqüente, provoca a conformação às expectativas estereotipadas da sociedade,

${ }^{475}$ BERGALLI, Roberto. Crítica a la Criminologia: hacia una teoría crítica del control social en América Latina. Bogotá: Temis, 1982.

${ }^{476}$ LEMERT, Edwin M. Social Pathology: a systematic approach to the theory of sociopathic behavior. 1. ed. Nova Iorque: Toronto: Londres: McGraw-Hill, 1951. p. 76. Ao lado da desviação secundária, em oposição a ela, Lemert formulou o conceito de desviação primária, cuja distinção entre ambas decorre da diferença que provocam na autodefinição da personalidade do seu autor. Nesta o sujeito ativo lida com seu ato ilícito em função de um papel socialmente aceitável, enquanto naquela a reação social faz com que o indivíduo assuma um papel que antes não the era destinado. Cf. LEMERT, Edwin M. Social Pathology: a systematic approach to the theory of sociopathic behavior. 1. ed. Nova Iorque: Toronto: Londres: McGraw-Hill, 1951.

${ }^{477}$ EINSTADTER, Werner J.; HENRY, Stuart. Criminological theory: an analysis of its underlying assumptions. 2. ed. Nova Iorque: Rowman \& Littlefield, 2006. 
a auto-representação como delinqüente, e o respectivo role-engulfment ${ }^{478}$ que, muitas vezes, será irreversível ${ }^{479}$.

Lemert desenvolve uma sequência de atos e interações, os quais ocorrem por parte do desviante e da sociedade, que se encerram com a configuração da desviação secundária $^{480}$.

O caminho inicia-se com a desviação primária; após ela têm lugar as reprimendas sociais; mais desviação primária ocorre; reprimendas mais rigorosas e rejeições são impingidas contra o desviante; mais desviação, e talvez sensações de hostilidade e início de ressentimento do autor contra os que o penalizam são passiveis de aparecer; inicia-se uma crise do quociente de tolerância ${ }^{481}$, expressa por meio de ações formais da comunidade estigmatizando o desviante; após isso se fortalece a conduta desviante como reação à estigmatização e às penalizações insurgidas contra o autor do desvio; e, por fim, ocorre a última aceitação do status desviante e a realização de esforços do autor para ajustar-se ao papel a ele associado.

Isso posto, fica evidente que não é a participação em uma ou outra infração que faz com que o sujeito assuma uma identidade criminosa. Certamente, a desviação primária é convencional, enquanto a secundária é primeiramente desviante ${ }^{482}$.

Algumas experiências sociais traumáticas podem acelerar processos de mudança da personalidade de um indivíduo, transformando profundamente sua autodefinição, ou seja, a imagem que ele tem de si próprio. Dentre essas situações prejudiciais, conforme já aludido no presente trabalho, destaca-se a reação social que se insurge desfavoravelmente contra o autor de um fato ilícito, determinante para sua mutação.

A reação social severa, com a atribuição de um novo papel público ao seu alvo, incorpora-se ao sujeito por meio de um mecanismo de identificação que faz com que ele

\footnotetext{
478 Trata-se de uma expressão introduzida na Criminologia pela teoria e que significa o mergulho do indivíduo no papel desviante que lhe foi atribuído. É um processo vinculado a formação das carreiras criminais e que será abordado no capítulo 4 do presente trabalho.

${ }^{479}$ DIAS, Jorge de Figueiredo; ANDRADE, Manuel da Costa. Criminologia: o homem delinqüente e a sociedade criminógena. 2 reimp. Coimbra: Coimbra Editora, 1997. p. 352-353.

${ }^{480}$ LEMERT, Edwin M. LEMERT, Edwin M. Social Pathology: a systematic approach to the theory of sociopathic behavior. 1. ed. Nova Iorque: Toronto: Londres: McGraw-Hill, 1951.

${ }^{481}$ É a "expressão quantitativa da desviação e do desejo da comunidade em aceitá-la ou rejeitá-la". É a fração matemática que indica, por seu numerador, a quantidade de condutas socialmente reprovadas e, em seu denominador, o grau de tolerância que as pessoas têm em relação às citadas condutas. Atingido um ponto crítico do quociente, estando ele na razão de 1 por 1, por exemplo, a população deve começar a agir para combater o comportamento. Cf. LEMERT, Edwin M. Social Pathology: a systematic approach to the theory of sociopathic behavior. 1. ed. Nova Iorque: Toronto: Londres: McGraw-Hill, 1951. p. 57.

${ }^{482}$ EINSTADTER, Werner J.; HENRY, Stuart. Criminological theory: an analysis of its underlying assumptions. 2. ed. Nova Iorque: Rowman \& Littlefield, 2006.
} 
despregue-se dos papéis sociais antes assumidos e reorganize-se de modo a aceitar e incorporar os novéis - negativos - que lhe são atribuídos.

Trata-se de uma ampla mudança da imagem pública do indivíduo que em determinado momento o afeta, esvaecendo as concepções que tinha sobre si, para assumir as que lhe foram creditadas pelos outros. Desse modo, "sendo mau, por ter sido definido como tal, o enjeitado sente que cumpriu uma ordem: foi submisso, conformou-se com a imagem com a qual foi rotulado e a sociedade deve a ele, senão aprovação, ao menos, aceitação" $^{\text {483. }}$.

Para os autores do labelling approach a intenção daqueles que rotulam o sujeito parece não importar, sendo certo que o fato mesmo de etiquetar já é a origem da discórdia $^{484}$.

Não obstante o relatado até aqui, importante ressalvar que nem todos os etiquetados publicamente assumem a atribuição que lhes foi dada, solidificando, assim, a desviação secundária. São os limites internos da personalidade do sujeito que seletivamente condicionam a aceitação de tais papéis, que, quando assumidos, tornam-se um novo conjunto de limites internos e externos, agora superimpostos sobre o anterior padrão ${ }^{485}$.

Nesse último caso o indivíduo, finalizada a assunção de seu novo papel, passa agora a lidar com as exigências impostas por sua nova condição social, praticando condutas e unindo-se a grupos cujos interesses são compatíveis com os seus.

Assim é que a aquiescência com a imagem de criminoso não lhe confere somente uma identidade, mas também o qualifica para ingressar no grupo de outros ilegais, proporcionando, assim, oportunidade para identidade grupal e sensação de pertinência ${ }^{486}$.

Note-se que essa incorporação do sujeito a um grupo subcultural deriva do fato de a reação social ter criado excluídos, que estão enfrentando os mesmos problemas dela decorrentes, e unem-se, por meio da ênfase em seu caráter distintivo, na tentativa de fortalecer-se e reagir a sua situação desfavorável.

Mister que se assevere que a gravidade das consequências da reação social negativa e do contato do sujeito com o sistema penal, quando eles possibilitam a completude do mecanismo de desviação secundária. Não só o indivíduo passa a enxergar-se de forma

\footnotetext{
${ }^{483}$ AMAR, Ayush Morad. Temas de Criminologia. São Paulo: Resenha Universitária, 1982. v. II. p. 86.

${ }^{484}$ EINSTADTER, Werner J.; HENRY, Stuart. Criminological theory: an analysis of its underlying assumptions. 2. ed. Nova Iorque: Rowman \& Littlefield, 2006.

${ }^{485}$ LEMERT, Edwin M. Social Pathology: a systematic approach to the theory of sociopathic behavior. 1. ed. Nova Iorque: Toronto: Londres: McGraw-Hill, 1951.

${ }^{486}$ AMAR, Ayush Morad. Temas de Criminologia. São Paulo: Resenha Universitária, 1982. v. II.
} 
diversa, mas também assume um novo estilo de vida, tudo em consonância com a definição negativa a ele atribuída.

Para os estudiosos do labelling approach é apenas nesse momento que o sujeito torna-se um criminoso, a despeito de bem antes já ser considerado como tal pelos demais. Nesse diapasão,

não se pode falar em 'delinqüente' até que o sujeito tenha assumido, por seu contato com os outros e especialmente com o sistema penal, esta nova identidade. A partir deste momento seus atos não estão guiados pelos impulsos que motivaram seus primeiros comportamentos delitivos, senão por esta nova identidade $^{487}$.

Após um primeiro momento em que esse processo ocorre inconscientemente, o desenvolvimento da desviação secundária perpassa algumas fases determinantes que podem culminar no estabelecimento de uma carreira delitiva, último mergulho do indivíduo na vida do crime ${ }^{488}$.

${ }^{487}$ LARRAURI, Elena. La herencia de la criminología crítica. 2. ed. Madri: Siglo veintiuno de España, 2000. p. 36-37.

${ }^{488}$ Esse assunto será desenvolvido no Capítulo 4 do presente trabalho. 


\section{CAPÍTULO 3. EVOLUÇÃO DO TRATAMENTO JURÍDiCO E CRIMINOLÓGICO DISPENSADO A CRIANÇAS E ADOLESCENTES EM CONFLITO COM A LEI}

\subsection{TRATAMENTO INDIFERENCIADO}

Tem-se como marco inicial dessa etapa o nascimento dos Códigos Penais liberais no século XIX. Característica precípua desse momento é que os infantes interessavam à norma apenas quando da prática de uma conduta ilícita, sendo a eles dirigida praticamente a mesma disciplina prevista para os adultos. A única diferenciação consistia numa atenuação das penas para os mais jovens.

No momento da chegada da Família Real ao Brasil, no ano de 1808, vigiam no país as Ordenações Filipinas, que consideravam vinte e um anos a idade de imputabilidade penal. No entanto, os que atingissem os sete anos desde logo podiam receber punições pelos seus atos ilegais, sendo elas elegidas em atendimento as circunstâncias do delito, seu modo de cometimento, bem como a pessoa do menor.

Seguia-se aqui a tradição instituída pelo direito romano de atenuar as sanções dos que ainda não houvessem atingido a maioridade penal, sem o que quase não havia diferença entre o tratamento das crianças e adultos ${ }^{489}$.

No tocante à pena de morte, os menores de dezesseis anos não podiam ser a ela submetidos, mas entre dezesseis e vinte e um anos existia a previsão da pena de morte natural. Esta consistia na expiação do ato criminoso por meio do enforcamento do seu autor no pelourinho, sendo seu corpo levado ao cemitério para o sepultamento pela Confraria da Misericórdia ${ }^{490}$.

\footnotetext{
${ }^{489}$ Até o século XVII a infância não era encarada como uma categoria ontológica e, por isso, não merecia abordagem diversa da dos adultos. É apenas depois desse marco que a criança passa a ser considerada de modo peculiar, entendimento que se constata nas fotografias tiradas nessa época, em que os infantes passam a ocupar o centro nos retratos e a trajar-se de maneira diferente dos adultos. Cf. GARCÍA MÉNDEZ, Emilio. La Convención Internacional de los Derechos de la Infancia: del menor como objeto de la compasiónrepresión a la infancia-adolescencia como sujeto de derechos. Capítulo Criminológico, Maracaíbo, n. 18/19, p. 177-193, 1990-1991.

${ }^{490}$ Os adultos, em contrapartida, sujeitavam-se ainda a outras espécies de penas capitais. A pena de morte natural pelo fogo, na qual o condenado era queimado vivo; a pena de morte natural cruelmente, a qual remetia às antigas execuções em que a crueldade do executor realizava um papel principal; e a morte natural
} 
É no ano de 1830 que surge o primeiro Código Penal do Brasil, denominado de Código Criminal do Império, inspirado no modelo francês datado de 1810 e fundamentado na combinação de ideias contratualistas e disciplinaristas.

Por meio desse diploma legal é que se introduziu no Brasil a pena privativa de liberdade, nos moldes da já existente no continente europeu ${ }^{491}$.

Pelo novo Código a idade de imputabilidade penal passa a ser, objetivamente, de quatorze anos. Entretanto, não obstante essa normatização, foi também instituído um critério biopsicológico para aferir a viabilidade da responsabilização dos infratores que tivessem entre sete e quatorze anos de idade, pautado pela constatação da existência de discernimento $^{492}$.

Comprovada a prática ilícita desses sujeitos e tendo-se verificado serem eles "conscientes" de seus atos, ocorria seu envio às casas de correção, onde podiam ficar privados de sua liberdade até os dezessete anos.

Aos infratores entre quatorze e dezessete anos de idade, por sua vez, eram aplicadas penas da mesma natureza a que se sujeitavam os adultos, entretanto, por um lapso temporal reduzido, denominadas, por isso, penas de cumplicidade. Finalmente, para os menores que contavam com idades entre dezessete e vinte e um anos, previa-se apenas a aplicação de uma atenuante relativa à menoridade.

Note-se que como a responsabilidade penal era prevista aos quatorze anos não havia qualquer óbice legal à reclusão conjunta, nos mesmos estabelecimentos, de crianças e adultos, numa clara concepção retributivo-expiatória da punição.

Ainda a realidade denunciava que, na falta de casas de correção, as quais, em flagrante afronta ao Código não foram sequer construídas nesse período, os menores de quatorze anos eram também recolhidos ao cárcere comum.

para sempre em que o criminoso era executado na forca, após o que seu corpo era pendurado em pontos da cidade até putrefar e cair.

${ }^{491}$ Tem-se que a privação da liberdade como pena surgiu no século XVI - com a instituição das casas de correção - na Inglaterra, tendo seu desenvolvimento mais expressivo ocorrido na Holanda, atrelada ao sistema de produção mercantilista, como instrumento apto para vigiar e controlar a força de trabalho, escassa nessa época. O cárcere nos moldes hoje conhecidos é herança dessas casas de correção e sua estruturação remonta aos fins do século XVIII. Cf. RUSCHE, Georg; KIRCHHEIMER, Otto. Punição e estrutura social. Tradução de Gizlene Neder. Rio de Janeiro: Freitas Barros, 1999.

${ }^{492}$ A fixação da idade de sete anos resultou de construções doutrinária e jurisprudencial, uma vez que o Código não estabelecia um limite cronológico mínimo para o início da persecução penal. 
O que se evidencia, pois, sobre esse momento em que vigia o Código Penal de 1830 é a ausência de um conjunto normativo, com princípios próprios, destinados aos menores de idade em conflito com a lei.

A única diferença em relação a disciplina dirigida ao adulto é que fomentava-se uma política assistencialista subsidiada pela Igreja e pelo Estado em relação às crianças necessitadas de proteção. Nesse sentido, pode-se afirmar que "a legislação relativa à infância nas primeiras décadas do Brasil Império referia-se a uma preocupação com o recolhimento de crianças órfãs e expostas" ${ }^{\natural 93}$.

O Código Penal de 1890, denominado de Código Penal dos Estados Unidos do Brasil, manteve a idade de responsabilização penal aos quatorze anos de idade, bem como o critério biopsicológico. No entanto, a indagação acerca do discernimento passou a ser realizada para os que estivessem na faixa etária entre nove e quatorze anos de idade.

Logo, a única alteração relevante encontrava-se no art. 27, com a disposição de que não seriam criminosos os menores de nove anos, uma vez que

ao contrário do Código Criminal do Império e, pela primeira vez na história da legislação brasileira, estipulou-se expressamente uma idade abaixo da qual o 'menor' seria absolutamente inimputável, não se admitindo sequer a apuração quanto ao discernimento pela prática da infração penal ${ }^{494}$.

Da mesma forma que no ordenamento jurídico anterior, os menores entre quatorze e dezessete anos sujeitavam-se às penas de cumplicidade e uma atenuante relativa à menoridade diminuía a sanção dos que ainda não houvessem completado vinte e um anos.

Persiste ainda, nesse período, a reclusão conjunta de todas as crianças e adultos, já que os estabelecimentos disciplinares industriais, substitutos das casas de correção e local onde os infantes entre nove e quatorze anos de idade deveriam ser recolhidos, também não saíram do papel.

A gravidade dessa segregação conjunta torna-se patente tendo em vista a natureza dos ilícitos praticados por cada um desses grupos etários, os quais eram indiscriminadamente misturados.

Entre os anos de 1900 e 1916, considerando-se grupos de dez mil habitantes, constatou-se uma média de reclusão de 307,32 adultos e 275,14 crianças e adolescentes, o

${ }^{493}$ SOARES, Janine Borges. A construção da responsabilidade penal do adolescente no Brasil: uma breve reflexão histórica. Revista do Ministério Público, Porto Alegre, n. 51, p. 255-286, ago./dez. 2003. p. 260.

${ }^{494}$ SAENZ, Fabiana Eduardo. Política Criminal e limite etário de responsabilização penal. 2008. $218 \mathrm{f}$. Dissertação (Mestrado em Criminologia) - Faculdade de Direito, Universidade de São Paulo, [2008]. p. 102. 
que demonstra certa paridade, em cada um dos conjuntos citados, na quantidade de sujeitos privados de liberdade.

Entretanto, verificou-se durante o período que vai de 1904 a 1906 que os adultos foram responsáveis por $93,1 \%$ dos homicídios, enquanto os menores de idade o eram por $22 \%$ das desordens, $22 \%$ das vadiagens $26 \%$ das gatunagens e $27 \%$ dos furtos e roubos. Ademais, $40 \%$ deles tiveram sua liberdade cerceada pela prática de desordem, $20 \%$ por vadiagem, $17 \%$ por embriaguez e $16 \%$ por crimes contra o patrimônio.

Esses números expressam duas situações bastante graves: a grande quantidade de crianças e adolescentes reclusos - e pela prática de ilícitos leves -, bem como sua submissão ao contato com adultos já mais inseridos no mundo criminoso, o que se deflui de seu envolvimento com práticas ilícitas bem mais graves ${ }^{495}$.

Note-se que, no que concerne à infância, não obstante significativas mudanças sociais ocorridas no período ${ }^{496}$, a disciplina jurídica ofertada pelos dois Códigos Penais foi bastante semelhante. Ambos permitiam a reclusão conjunta de sujeitos, independentemente de sua faixa etária; não distinguiam os conceitos de criança e adolescente; determinavam a aplicação de penas meramente retributivas aos infantes; baseavam na comprovação do discernimento a reclusão dos indivíduos mais jovens.

Isso se explica porque toda a carga ideológica que embasava as intervenções da Justiça nestes momentos considerados era a mesma. Nesse sentido, ressalta Shecaira que

o período compreendido entre os dois primeiros códigos brasileiros e o início do século XX marca o apogeu do pensamento Iluminista, que contemplava a polêmica entre clássicos e positivistas. Se de um lado encontramos a concepção do livre-arbítrio como pedra de toque da questão do discernimento, de outro a concepção positivista via a periculosidade como atributo de criminoso anormal era a visão mais aguda da intervenção penal ${ }^{497}$.

Tratava-se, pois, de um momento que a necessidade da intervenção penal considerava-se indispensável, essencial.

Importante deter-se aqui ao discernimento, perquirido no caso dos mais jovens, como forma de permitir a subordinação dos infantes ao regime jurídico penal. Representa

${ }^{495}$ SANTOS, Marco Antônio Cabral dos. Criança e criminalidade no início do século. In: DEL PRIORE, Mary (Org.). História das crianças no Brasil. São Paulo: Contexto, 2007.

${ }^{496}$ Destaque-se a edição da lei n. 2.040 de 28 de setembro de 1871 , a qual representou um marco jurídico de defesa dos direitos da criança, ao declarar livres os filhos de mulher escrava. Ademais, tendo em vista a escassez e a necessidade de mão-de-obra livre foi abolida pelo novo Código qualquer espécie de pena de morte, havendo previsão apenas de penas de prisão de caráter temporário e finalidade de ressocialização, com o escopo de educar o futuro egresso para o mercado de trabalho.

${ }^{497}$ SHECAIRA, Sérgio Salomão. Sistema de Garantias e o Direito Penal Juvenil. São Paulo: Revista dos Tribunais, 2008. p. 33. 
ele a investigação da consciência do autor acerca do caráter delituoso do ato, no momento em que ele é praticado. Baseia-se esse critério na ideia de que a malícia supre a pouca idade nos casos em que o sujeito age com a consciência do bem e do mal ${ }^{498}$.

Entretanto, sua imprecisão, o fato de configurar-se como um parâmetro extremamente subjetivo, denunciava ser um método nada seguro para se afirmar se o infante tinha ou não consciência da carga negativa de sua conduta.

De qualquer modo esse critério foi perdendo sentido, mais tarde, com as mudanças das concepções sobre as finalidades das sanções, sendo deixado de lado definitivamente quando se evidenciou o fim preventivo especial das penalidades, exigindo-se para combater a delinquência dos menores de idade a proposição de medidas de correçãoeducação $^{499}$.

O modelo de intervenção indiferenciada não ficou imune a críticas.

As primeiras objeções sociais a ele direcionadas destacavam os malefícios advindos da reclusão conjunta de pessoas cujo estágio de desenvolvimento era tão distinto. Nessa esteira, o movimento dos reformadores, pioneiro nesta luta, foi um dos grandes responsáveis pela cessação do controle igualitário de adultos e infantes.

Trata-se de um agrupamento - formado em grande parte por mulheres da alta sociedade norte-americana que o encaravam como uma oportunidade de ascensão e interação social - inconformado com as condições de reclusão a que estavam sendo submetidos os menores de idade, com sua mistura indiscriminada com os adultos, bem como com a ausência de uma normativa específica a eles destinada.

Também foram de fundamental importância para a futura implementação de doutrinas especialmente dirigidas aos inimputáveis, ainda como consequência do movimento que se iniciou com os reformadores, a realização, em Paris, no ano de 1911, do Congresso Internacional de Menores ${ }^{500}$ e a Declaração de Genebra de Direitos da Criança $^{501}$, adotada pela Liga das Nações em 1924.

\footnotetext{
${ }^{498}$ GARCÍA DE PAZ, Maria Isabel Sánchez. Minoría de edad y derecho penal juvenil. Granada: Comeres, 1998.

${ }^{499}$ ROSAL BLASCO, Bernardo del. Joven delincuente y Derecho Penal. Cuadernos de Política Criminal, Madri, n. 54, p. 1037-1051, 1994.

${ }^{500}$ Os principais temas debatidos no Congresso foram as péssimas condições de reclusão dos menores e a necessidade de flexibilização, ou mesmo de desconsideração, nessa seara, do principio da legalidade, o qual impedia a realização da proteção desses sujeitos.

${ }^{501}$ Nesse documento a criança é colocada numa situação claramente passiva, considerada mero objeto de proteção. Cf. MONACO, Gustavo Ferraz de Campos. A Declaração Universal dos Direitos da Criança e seus sucedâneos internacionais: tentativa de sistematização. Coimbra: Coimbra, 2004.
} 
Fato é que se seguiram a esses eventos inúmeras modificações legislativas, em todo o mundo, as quais esboçavam a demanda pela especialização de uma chamada Justiça de Menores.

No Brasil foi iniciada a mudança, no plano jurídico, com o advento da Lei 4.242, de 4 de janeiro de 1921, que entre suas inovações determinou a adoção, em seu artigo 30, parágrafo 16, de um critério cronológico de imputabilidade penal, sendo esta iniciada aos quatorze anos completos. Portanto, deixava de ser necessária a perquirição do discernimento, que tantos abusos permitiu ${ }^{502}$.

Em 1922 realizou-se também no país o I Congresso Brasileiro de Proteção à Infância, presidido por Mancorvo Filho, o inaugurador da medicina higienista na segunda metade do século XIX, o que já dá o tom do que serão os primeiros momentos da especialização da Justiça de Menores ${ }^{503}$.

Outrossim, importante consignar que as propostas inicialmente indicadas pelo movimento dos reformadores e que deram origem à pretendida criação de um sistema de justiça especializado foram facilmente aceitas pelos demais setores da sociedade por duas razões principais, quais sejam, as funções de controle social das classes menos favorecidas implícitas nessas propostas e a asseguração de que as novas ideias de intervenção não seriam estendidas aos adultos ${ }^{504}$.

\subsection{ESPECIALIZAÇÃO DA JUSTIÇA JUVENIL}

Podem-se identificar dois momentos diametralmente distintos da Justiça Juvenil especializada, conformados pelas doutrinas da Situação Irregular e da Proteção Integral,

\footnotetext{
${ }^{502}$ Vale consignar que o critério do discernimento voltaria a ser aceito pelo legislador pátrio no artigo 33 do Código Penal de 1969, o qual, entretanto, foi revogado antes mesmo de sua entrada em vigor. Não obstante, o Código Penal Militar, editado na mesma data, adotou a perquirição do discernimento para os jovens que tivessem entre dezesseis e dezoito anos, suspeitos de prática infracional. Assim, esse critério só foi definitivamente afastado de nossa legislação com a promulgação da Constituição Federal de 1988 e seu artigo 228. Cf. MASSA, Patrícia Helena. A menoridade Penal no Direito Brasileiro. Revista Brasileira de Ciências Criminais, São Paulo, ano 1, n. 4, p. 126-132, out.Idez. 1993.

${ }^{503} \mathrm{O}$ saber médico, de cunho científico, foi utilizado pelo Positivismo Criminológico, visando a justificar o controle social que realizava. Trata-se do modelo biologista ou médico higienista. O controle médico submetia ao seu crivo indivíduos e seus comportamentos, os quais eram categorizados como normais ou anormais. Estes, pregava-se, tinham que ser enclausurados para retornarem aos bons sentimentos, ou seja, para serem reeducados e corrigidos. Cf. PEDRINHA, Roberta Duboc. Sexualidade, controle social e práticas punitivas: do signo sacro religioso ao modelo científico médico higienista. Rio de Janeiro: Lumen Juris, 2009.

${ }^{504}$ GARCÍA MÉNDEZ, Emilio. Política de la infancia/adolescencia en América Latina. Estado, movimiento social y modelo jurídico-institucional: tendencias y perspectivas. Doctrina Penal: Teoría y práctica en las Ciencias Penales, Buenos Aires, a. 14, n. 55/56, p. 479-489, jul./dez. 1991.
} 
historicamente surgidas nessa ordem. Ambas, conforme se verá, podem ser encaradas como aspectos negativo e positivo da especialização, respectivamente.

Na primeira etapa introduziu-se a especialização das leis e tribunais relativos aos menores de idade, enquanto na segunda, ainda hoje em evolução, houve uma mudança no trato das questões relativas à infância e juventude, cujo marco inicial corresponde à elaboração da Convenção das Nações Unidas sobre os Direitos da Criança ${ }^{505}$.

O primeiro Tribunal de Menores instalou-se nos Estados Unidos, em Illinois, no ano de 1899, inaugurando a intervenção conforme o sistema tutelar ${ }^{506}$.

No Brasil, a teorização serviu como base para os Códigos de Menores de 1927, conhecido como Código de Mello Matos, e de 1979 (Lei 6.697/79).

Sob sua égide, o tratamento jurídico especificamente dirigido aos não-adultos tinha como fundamento a consideração da infância como categoria diversa da adulta, em virtude da incapacidade inerente a esse grupo de pessoas $^{507}$.

Para usar a expressão de Zaffaroni, é a representação da máxima "discriminação biológica em relação aos menores" ${ }^{\text {,508. }}$.

É em observância à premissa mencionada que se construiu a categoria "menor", avaliado como um ser incompleto e inadaptado que só consegue, com ajuda, reincorporarse à sociedade ${ }^{509}$.

Não se refere o termo simplesmente a uma terminologia de idades que indica a oposição entre maior e menor, mas sim a expressão que intitula o que não é sujeito de direitos, que não tem qualidade de pessoa e que é objeto dos outros ${ }^{510}$. Na esteira desse

505 No Contexto específico da América Latina, as citadas etapas da especialização podem ser cronologicamente determinadas: a primeira iniciou sua hegemonia a entre 1919 e 1939 e a segunda no de 1990. Cf. GARCÍA MÉNDEZ, Emilio. Infancia, ley y democracia: uma cuestión de justicia. Ciencias Penales: Revista de la Asociación de Ciencias Penales de Costa Rica, Costa Rica, a.10, n. 15, p. 58-71, dez. 1998.

${ }^{506}$ A criação do primeiro tribunal destinado exclusivamente aos menores é considerada o marco zero da história da especialização da Justiça de controle desses sujeitos. Cf. GARCÍA MÉNDEZ, Emilio. Política de la infancia/adolescencia en América Latina. Estado, movimiento social y modelo jurídico-institucional: tendencias y perspectivas. Doctrina Penal: Teoría y práctica en las Ciencias Penales, Buenos Aires, a. 14, n. 55/56, p. 479-489, jul./dez. 1991.

${ }^{507}$ COSTA, Ana Paula Motta. As garantias processuais e o Direito Penal Juvenil como limite na aplicação da medida socioeducativa de internação. Porto Alegre: Livraria do Advogado, 2005.

${ }^{508}$ ZAFFARONI, Eugenio Raúl. Minorias desplazadas, delincuencia y poder punitivo. Eguzkilore. Cuaderno del Instituto Vasco de Criminología, San Sebastián, n. 7 (ext.), p. 83-92, dez. 1994. p. 84.

${ }^{509}$ SOTOMAYOR, Carlos Tiffer. De un Derecho Tutelar a un Derecho Penal MínimoIGarantista: nueva Ley de Justicia Penal Juvenil. Ciencias Penales .Revista de la Asociación de Ciencias Penales de Costa Rica, San José , n. 13, p. 98-109, ago. 1997.

${ }^{510}$ BUSTOS RAMÍREZ, Juan. Perspectivas de un Derecho Penal del Niño. Nueva Doctrina Penal, Buenos Aires, v. A, p. 63-71, 1997. 
pensamento "o menor apareceu como estrangeiro, dentro da própria terra em que nasceu. Terra esta que o negava, condenando-o ao pior dos mundos, julgando-o portador das chagas sociais, disseminando medo e desconfiança" ${ }^{\text {"511. }}$.

Trata-se, pois, de um significado imbuído de preconceitos e relacionado a incapacidades.

Em razão da pretensa incapacidade dos infantes é que um juiz quem deveria decidir o que seria melhor para eles. Ele era o exemplo do bom "pai de família", cuja tarefa era determinar a providência mais benéfica que deveria ser adotada diante do menor. Não precisava este, então, da enunciação de qualquer direito em seu favor, uma vez que o magistrado o protegeria de todo e qualquer mal.

Evidencia-se, assim, que a

\begin{abstract}
legislação está concebida paternalisticamente, administrando o menor de modo coisificado, sob o pretexto de tutelá-lo e protegê-lo melhor, desde a perspectiva do que é mais que ele, do que sabe mais que ele. Muitos juízes não vêem contradição alguma nesta imputação, precisamente porque sua concepção de mundo e da educação está conformada nos mesmos valores plasmados na legislação e na administração do patronato $^{512}$.
\end{abstract}

Também no âmbito processual o poder do juiz é ilimitado. A ele é conferida a prerrogativa de dirigir a instrução, durante a qual só são admitidas as provas que ele próprio considerar necessárias, bem como de aplicar as medidas que entender adequadas ao caso concreto, mesmo que não tenha antecedido a esse momento a realização de uma audiência para produção de prova ${ }^{513}$.

Esse novo modelo de justiça tem, pois, caráter administrativo e jurisdicional ${ }^{514}$. Tal administrativização, de acordo com Zaffaroni, permitiu que por meio da tutela dos menores fossem excluídas do discurso jurídico-penal, e consequentemente do âmbito de exigibilidade do princípio da legalidade, as institucionalizações desses sujeitos. Nas palavras do autor,

a perversão do discurso jurídico-penal faz com que se recuse, com horror, qualquer vinculação dos menores (especialmente os abandonados), dos doentes mentais, dos anciões e, inclusive, da própria prostituição com o discurso jurídico-penal, embora submetam-se todos esses grupos a institucionalizações,

\footnotetext{
${ }^{511}$ RODRIGUES, Gutemberg Alexandrino. Os filhos do mundo: a face oculta da menoridade (1964-1979). São Paulo: IBCCRIM, 2001. p. 148.

${ }^{512}$ ELBERT, Carlos Alberto. Menores em situación irregular y proyectos legislativos en la Argentina actual. Doctrina Penal: Teoría y Práctica en las Ciencias Penales, Buenos Aires, v. 11, n. 41-44, p. 443 - 459 , 1988. p. 449-450. No excerto citado o autor refere-se especificamente à legislação Argentina, entretanto tal consideração pode ser estendida a todos os países que adotavam a doutrina da Situação Irregular.

${ }^{513}$ GERSÃ̃O, Eliana. Menores agentes de infrações: interrogações acerca de velhas e novas respostas. Revista Portuguesa de Ciência Criminal, Coimbra, v. 4, n. 2, p. 241-259, abr.Ijun. 1994.

${ }^{514}$ HERRERO, César Herrero. Criminologia. 2. ed. Madri: Dykinson, 2001.
} 
aprisionamentos e marcas estigmatizantes autorizadas ou prescritas pela própria lei que são, num todo, semelhantes - e, frequentemente, piores - do que as abrangidas pelo discurso jurídico-penal ${ }^{515}$.

Caracteriza-se esse sistema, então, pela imposição, sem quaisquer das garantias substantiva ou processual válidas para o adulto, de medidas correcionais arbitrariamente determinadas por um juiz de menores que nem sequer é funcionário de carreira ${ }^{516}$.

Por isso, pode-se defender que

não estávamos na presença de verdadeiros tribunais, no sentido de órgãos jurisdicionais revestidos das garantias de imparcialidade, inamovibilidade e independência, mas sim perante órgãos de natureza especial sem outra garantia que não fossem as boas intenções dos seus componentes ${ }^{517}$.

Ocorre que, "na história da 'proteção dos menores', os eufemismos da bondade não conhecem limites" ${ }^{\prime 518}$.

O amplo conceito de situação irregular, central na doutrina, como sua própria denominação indica, delimitava a necessidade ou não da interferência estatal e a configuração de duas infâncias distintas: a das crianças e adolescentes em situação regular, aos quais a lei era indiferente, e os menores, meros objetos da ação estatal, por estarem em situação considerada irregular ${ }^{519}$. Aqueles eram controlados e socializados pela família e pela escola, estes pelo Tribunal de Menores ${ }^{520}$.

Assim, pela doutrina da Situação Irregular, toda criança ou adolescente, fossem eles carentes, abandonados ou infratores, seriam tratados como menores em situação irregular, como se eles devessem responder pela ineficiência de um sistema, este sim irregular, uma vez que nem sequer levava em consideração sua condição de pessoa em desenvolvimento $^{521}$.

Diante disso, essa ideologia

${ }^{515}$ ZAFFARONI, Eugenio Raúl. Em busca das penas perdidas: a perda de legitimidade do sistema penal. Tradução de Vânia Romano Pedrosa e Amir Lopes da Conceição. 5. ed. Rio de Janeiro: Revan, 2001. p. 22.

${ }^{516}$ GARCÍA DE PAZ, Maria Isabel Sánchez. La nueva ley reguladora de la responsabilidad penal del menor. Actualidad Penal, Madri, n. 33, p. 699-729, set. 2000.

${ }^{517}$ GÓMEZ, Manuel Marchena. A Justiça de Menores em Espanha: tempos de reforma. Revista do Ministério Público, Lisboa, v. 19, n. 73, p. 117-124, jan.Imar. 1998. p. 118.

${ }^{518}$ GARCÍA MÉNDEZ, Emilio. Infancia, ley y democracia: uma cuestión de justicia. Ciencias Penales: Revista de la Asociación de Ciencias Penales de Costa Rica, Costa Rica, a.10, n. 15, p. 58-71, dez. 1998. p. 63.

${ }^{519}$ SARAIVA, João Batista Costa. Compêndio de Direito Penal Juvenil: adolescente e ato infracional. 3. ed. Porto Alegre: Livraria do advogado, 2006.

${ }^{520}$ GARCÍA MÉNDEZ, Emilio. La Convención Internacional de los Derechos de la Infancia: del menor como objeto de la compasión-represión a la infancia-adolescencia como sujeto de derechos. Capítulo Criminológico, Maracaibo, n. 18/19, p. 177-193, 1990-1991.

${ }^{521}$ CASTRO, Ana Márcia de Souza. Alternativas ao jovem infrator. Revista do ILANUD, São Paulo, n. 12, p. 17-24, 1998. 
converte a criança e o jovem em objeto, não em sujeito de direitos, em um ser dependente, que há de ser submetido a intervenção protetora e educadora do Estado, a qual é profundamente seletiva, pois irregular ou perigoso se iguala com situação de abandono, é dizer, com as crianças e adolescentes pertencentes as classes ou grupos mais desfavorecidos e, portanto, onde os processos de socialização foram mais deficitários e isso se pretende substituir através de medidas sancionatórias. A ideologia da situação irregular, protetora ou educativa, provoca uma identificação entre proteção a criança e sanção, sobre a base de um pretendido objetivo de beneficência ou bem-estar ${ }^{522}$.

Pode-se perceber, portanto, que se adotava uma concepção ampla de delinquência juvenil, a qual abarcava os atos contrários à lei penal cometidos pelos menores, bem como sua condição inadequada de vida ${ }^{523}$.

Acreditava-se, primordialmente, que o comportamento delinquente era consequência de uma inadequada situação social, familiar, psicológica e econômica ${ }^{524}$. Evidente, assim, que o sistema tutelar lançava suas garras, majoritariamente, sobre os jovens marginalizados, necessitados de uma melhor estruturação das políticas sociais: a “criminalização da pobreza, a judicialização da questão social na órbita do então Direito do Menor, era o que orientava os Juizados de Menores da época” ${ }^{, 525}$.

Destarte, para García Méndez, a extensão do uso da doutrina da Situação Irregular é inversamente proporcional à extensão e qualidade das políticas sociais básicas ${ }^{526}$.

Nessa perspectiva, falha o Estado ao cercear os direitos daqueles que já de antemão ajudara a excluir.

Consoante já aventado, a aplicação e a escolha da medida dependiam da análise apurada da situação de vida do menor e não propriamente de algum ato ilícito por ele perpetrado ${ }^{527}$. A pena era imposta com base na adivinhação do juiz de menores acerca da futura possibilidade de prática criminosa, determinada por sua condição de existência, o

${ }^{522}$ BUSTOS RAMÍREZ, Juan. Perspectivas de un Derecho Penal del Niño. Nueva Doctrina Penal, Buenos Aires, v. A, p. 63-71, 1997. p. 63.

${ }^{523}$ GIMÉNEZ-SALINAS COLOMER, Esther. Tratamiento jurídico de la delincuencia de menores en España. Doctrina Penal: Teoría y práctica en las ciencias penales, Buenos Aires, v. 4, n.13-16, p. 261-278, 1981.

${ }^{524}$ BARANGER, Thierry; SALAS, Denis. Le juge des enfants fait-il encore autorite? Archive de Politique Criminelle, Paris, n. 30, p. 25-35, 2008.

${ }^{525}$ SARAIVA, João Batista Costa. Compêndio de Direito Penal Juvenil: adolescente e ato infracional. 3. ed. Porto Alegre: Livraria do advogado, 2006. p. 26.

${ }^{526}$ GARCÍA MÉNDEZ, Emilio. La Convención Internacional de los Derechos de la Infancia: del menor como objeto de la compasión-represión a la infancia-adolescencia como sujeto de derechos. Capítulo Criminológico, Maracaíbo, n. 18/19, p. 177-193, 1990-1991.

${ }^{527} \mathrm{Na}$ Situação Irregular, com o primado do direito penal do autor, violava-se o principio da responsabilidade por um fato, limitador da responsabilização pessoal dos imputados. É a mais clara visão de um Direito Penal do autor. 
que implicava uma observação contínua e intensiva da criança ou adolescente sujeitos ao Tribunal $^{528}$.

Em Portugal, por exemplo, no ano de 1981, 46\% dos internamentos eram decorrentes de prática ilícita, enquanto 53,9\% se deviam a causas não criminais. Já no ano de 1991 essa discrepância tornou-se ainda mais evidente, levando aos índices de 25,7\% e $74,2 \%$, respectivamente ${ }^{529}$.

Também no Brasil, na Unidade de Triagem 2, em um total de 159 internações, 79 ocorreram por motivação econômica, ou seja, pela situação de pobreza da família do menor $^{530}$.

A veracidade de tais dados pode ser indiciada por meio de uma opinião que aclara o pensamento dominante na época:

não tenho dúvidas a respeito, posto que em matéria de menores a eventual punição não obedece em absoluto a uma razão de justiça nem de retribuição; elas são alheias a lei, que substituiu a culpabilidade, como fundamento da sanção, pela periculosidade delitiva do incapaz ${ }^{531}$.

Cumpria-se, com a observância a essa lógica interventiva, o objetivo primordial da Justiça de Menores: o “"sequiestro social' de todos aqueles em situação irregular",532, uma vez que o método de ação utilizado por excelência nesse modelo era o internamento, por tempo indeterminado.

Nesse sentido, "a institucionalização tornou-se, portanto, inquestionável como forma de prevenção e tratamento, em consonância com as ideias lombrosianas de que o meio poderia ser a causa da delinqüência juvenil" ${ }^{1533}$.

Fato é que

o caráter 'maximalista' e 'totalizante' do sistema - a ideia de que lhe cabe substituir em absoluto os pais na educação do menor - conduzira à sua

\footnotetext{
${ }^{528}$ Em observância a essa visão a Justiça de Menores cunhou novos termos no mundo jurídico, tal qual o de estado pré-delitivo, visando a atender a ideia de que a ciência permitia aos magistrados adiantar-se e prever o que era considerado inevitável. Cf. GARRIDO, Elena Azaola. Análisis institucional e instituiciones normalizadoras: un estudio sobre las instituiciones correccionales en México. Doctrina Penal: Teoría y Práctica en las Ciencias Penales, Buenos Aires, v. 13, n. 49-53, p. 9-21, 1990.

${ }^{529}$ GERSÃO, Eliana. Menores agentes de infrações: interrogações acerca de velhas e novas respostas. Revista Portuguesa de Ciência Criminal, Coimbra, v. 4, n. 2, p. 241-259, abr.Ijun. 1994. p. 247. Ressalte-se que nessa época ainda vigia no país uma legislação orientada por critérios tutelares e assistencialistas, a Lei 314/78, conhecida como Lei de Organização Tutelar de Menores.

${ }^{530}$ RODRIGUES, Gutemberg Alexandrino. Os filhos do mundo: a face oculta da menoridade (1964-1979). São Paulo: IBCCRIM, 2001

${ }^{531}$ MITCHELL, Wagner Gustavo. La necesidad de imponer pena al menor: art. 4 de la ley 22.278. Doctrina Penal: Teoría y Práctica en las Ciencias Penales, Buenos Aires, v. 4, n. 13 -16, p. 521-531, 1981. p. 522.

${ }^{532}$ COSTA, Ana Paula Motta. As garantias processuais e o Direito Penal Juvenil como limite na aplicação da medida socioeducativa de internação. Porto Alegre: Livraria do Advogado, 2005. p. 54.

${ }^{533}$ SPOSATO, Karyna Batista. O Direito Penal Juvenil. São Paulo: Revista dos Tribunais, 2006. p. 38.
} 
bipolarização em duas posições extremas - ou seja, ou nada fazer ou internar o menor nas 'instituições totais' (no sentido de Goffman) que são os estabelecimentos tutelares $^{534}$.

Evidente, ante o exposto até aqui, que a proteção na fase tutelar não é concebida sob a ótica dos direitos fundamentais. Também não se organiza o ordenamento jurídico sob a premissa de que crianças e adolescentes tinham os mesmos direitos humanos dos adultos $^{535}$.

Trata-se, de acordo com Méndez, de "uma justiça com as aparências objetivas e abstratas da lei, mas com os conteúdos e o funcionamento real da discricionariedade médica"536. Misturava-se assistencialismo com um ideal abstrato de justiça para a realização do saneamento moral dos menores ${ }^{537}$.

Os Códigos de Menores fizeram a opção - ainda que velada por seu discurso - de proteger a sociedade às custas da desconsideração do infrator e sua transformação em mero objeto. Privilegiou-se, pois, a segurança e tranquilidade da sociedade, ao preço da violação dos direitos fundamentais dos menores ${ }^{538}$.

O surgimento dessa forma de disciplinamento dos não adultos não se deu por obra do acaso, podendo ser atribuída a concepções de política criminal ${ }^{539}$.

A fundamentação político-criminal sobre a qual a doutrina da Situação Irregular se sustenta, descreve Bustos Ramírez, ancora-se na ideologia retribucionista, especialmente na noção de inimputabilidade adotada nos Códigos Penais da época, bem como na ideologia positivista naturalista inspiradora das legislações de menores. Entretanto, destaca o autor que há maculas nesses conceitos que têm de ser destacadas, justamente por permitirem essa concepção errônea acerca dos infantes.

Pelo pensamento vigente à época, a inimputabilidade leva em conta a incapacidade de conhecimento da ilicitude de um fato, o que alimenta uma tendência de reconhecimento

${ }^{534}$ GERSÃO, Eliana. Ainda a revisão da Organização Tutelar de Menores: memória de um processo de reforma. In: DIAS, Jorge de Figueiredo et al. (Org.). Estudos em homenagem a Cunha Rodrigues. Coimbra: Coimbra Editora, 2001. p. 447-476. v. 1. p. 463.

${ }^{535}$ MACHADO, Martha de Toledo. Sistema especial de proteção da liberdade do adolescente na Constituição brasileira de 1988 e no estado da criança e do adolescente. In: ILANUD et al. (Org.). Justiça, adolescente e ato infracional: socioeducação e responsabilização. São Paulo: ILANUD, 2006. p. 96.

${ }^{536}$ GARCÍA MÉNDEZ, Emilio. Infancia, ley y democracia: uma cuestión de justicia. Ciencias Penales: Revista de la Asociación de Ciencias Penales de Costa Rica, Costa Rica, a. 10, n. 15, p. 58-71, dez. 1998. p. 64.

${ }^{537}$ SHECAIRA, Sérgio Salomão. Sistema de Garantias e o Direito Penal Juvenil. São Paulo: Revista dos Tribunais, 2008.

${ }^{538}$ FELLINI, Zulita. La nueva legislación penal mexicana sobre menores infractores, en el marco de la declaración sobre los derechos del niño. Doctrina Penal: Teoría y Práctica en las Ciencias Penales, Buenos Aires, v. 14, n. 55-56, p. 623-630, jul.Idez. 1991.

${ }^{539}$ FERNANDES, Newton e Valter. Criminologia Integrada. 2. ed. São Paulo: Revista dos Tribunais, 2002. 
do menor como um ser dependente, que não tem autonomia. Porém, Bustos Ramirez identifica duas objeções nessa construção: acredita que essa ideia baseia-se no livre arbítrio, o qual é indemonstrável e, portanto, não pode servir como fundamento jurídico, e que esse pensamento é contrário ao princípio constitucional de respeito à dignidade da pessoa humana, segundo o qual toda pessoa tem autonomia, direitos e obrigações, sendo inerente a ela ser responsável por suas condutas.

No tocante à influência positivista relata que ela pretende validar a afirmação de que as medidas destinadas aos menores visam apenas à sua tutela e proteção, razão pela qual seriam qualitativamente distintas da pena. Todavia, para o autor, ambas implicam restrições a liberdade do sujeito adulto ou jovem, sendo que a finalidade por ela adotada não muda sua natureza coativa e de restrição de direitos ${ }^{540}$.

Logo, a doutrina da Situação Irregular sofreu influências notáveis da Criminologia positivista e da defesa social, elevando-se o caráter etiológico da delinquência juvenil, sujeita a fatores hereditários e do meio ambiente ${ }^{541}$.

Nesse diapasão, Garrido analisou documentos escritos por juízes e funcionários dos primeiros tribunais especializados, datados de 1927 e 1930, disponíveis no Arquivo Geral da Nação do México. Concluiu que todos os 3.274 menores submetidos ao controle jurisdicional nesse período eram por eles considerados pobres ou miseráveis; $60 \%$ eram filhos de pais alcoólatras, razão pela qual eram considerados heredo-alcoólicos por esses profissionais; $50 \%$ considerados heredosifilíticos e $18 \%$ heredotuberculosos, sendo esses fatores explicativos de sua situação irregular ${ }^{542}$.

Inúmeros aspectos do Positivismo criminológico podem ser identificados no trato dos menores. Destaque-se, dentre eles, a consideração das crianças delinquentes como anormais e sua equiparação aos doentes; o ideal da ressocialização e o anseio de adaptar esses sujeitos aos valores da classe dominante; o uso da internação em benefício e para

\footnotetext{
${ }^{540}$ BUSTOS RAMÍREZ, Juan. Hacia la desmitificación de la facultad reformadora de menores: por um derecho penal de menores. In:____ (Dir.). Un Derecho Penal del Menor. Santiago: Conosur, 1992.

${ }^{541}$ BUSTOS RAMÍREZ, Juan. Perspectivas de un Derecho Penal del Niño. Nueva Doctrina Penal, Buenos Aires, v. A, p. 63-71, 1997.

${ }^{542}$ GARRIDO, Elena Azaola. Análisis institucional e instituiciones normalizadoras: un estudio sobre las instituiciones correccionales en México. Doctrina Penal: Teoría y Práctica en las Ciencias Penales, Buenos Aires, v. 13, n. 49-53, p. 9-21, 1990.
} 
reeducação dos jovens; e a ausência de processos e garantias legais, uma vez que o sistema estava incumbido da tarefa de curar as crianças ${ }^{543}$.

Ademais, por conta dessa ideologia, de claro caráter individualista, detectava-se que o problema sempre estava no menor e nunca na tratativa que a ele destinava a sociedade ${ }^{544}$. Procuravam-se as deficiências no mundo dos excluídos socialmente, sem criticar as estruturas condicionadoras dessa situação ${ }^{545}$.

Assim, devido a essas explicações criminológicas sobre a delinquência, "o menor seria estigmatizado, marcado com o rótulo de infrator periculoso, disseminando, no imaginário social e coletivo, a figura a ser vigiada e controlada" ${ }^{, 56}$.

Mais especificamente, essa etapa da especialização da Justiça de Menores representa o acolhimento da vertente do Correcionalismo, especialmente o desenvolvido na Espanha $^{547}$.

Essa teorização privilegia o aspecto valorativo da intervenção estatal ao defender uma transformação qualitativa do sujeito por meio das medidas impostas. Acredita-se que

o delinqüente é um ser incapaz de dirigir livremente, por si mesmo, sua vida, um necessitado de ajuda; o delito, conseqüência de uma 'vontade' débil, viciada ou pervertida; e a reação jurídica, um bem, e inclusive um direito do delinqüente, que está obrigado a lhe prestar o Estado, e que tem como única justificação a correção e emenda daquele ${ }^{548}$.

Mais tarde, a Situação Irregular continuou seguindo as mudanças ocorridas na seara criminológica e adaptou-se às teorias sociológicas da Criminologia, surgidas a partir da década de 1920, as quais, consoante já se consignou no capítulo 1 do presente trabalho, não conseguiram desvincular-se completamente do Positivismo.

As concepções antropológicas justificadoras da necessidade de intervenção - como a hereditariedade - foram simplesmente substituídas por outras sociológicas, também

${ }^{543}$ FRASSETO, Flávio Américo. Execução da medida sócio-educativa de internação: primeiras linhas de uma crítica garantista. In: ILANUD et al. (Org.). Justiça, adolescente e ato infracional: socioeducação e responsabilização. São Paulo: ILANUD, 2006.

544 GIMÉNEZ-SALINAS COLOMER, Esther. Tratamiento jurídico de la delincuencia de menores en España. Doctrina Penal: Teoría y práctica en las ciencias penales, Buenos Aires, v. 4, n.13-16, p. 261-278, 1981.

${ }^{545}$ RODRIGUES, Gutemberg Alexandrino. Os filhos do mundo: a face oculta da menoridade (1964-1979). São Paulo: IBCCRIM, 2001.

${ }^{546}$ RODRIGUES, Gutemberg Alexandrino. Os filhos do mundo: a face oculta da menoridade (1964-1979). São Paulo: IBCCRIM, 2001. p. 159.

${ }^{547}$ DIAZ, Eliseo del Blanco. La reforma de Menores: Diseño procesal de la Ley 4I92: Princípios y Derechos Fundamentales inherentes al proceso. Estúdios del Ministério Fiscal, Madri, n. 3, p. 603-612, 1995.

${ }^{548}$ GARCÍA-PABLOS DE MOLINA, Antonio. La supuesta función resocializadora del Derecho Penal: utopia, mito y eufenismo. Anuario de Derecho Penal y Ciencias Penales, Madri, v. 32, n. 2, p. 645-700, mai.Iago. 1979. p. 659. 
autorizadoras da ingerência penal, tais quais as condições familiares em que o menor estava inserido, seu local de moradia, entre outras.

Note-se que sua capacidade de adaptação ao pensamento criminológico predominante em cada momento é uma das explicações para sua tão prolongada hegemonia $^{549}$. García Méndez aponta também outras razões para a sobrevivência da Situação Irregular por tão longo período. Dentre elas se destaca a circunstância de a produção dos textos sobre a matéria ter sido realizada pelos próprios aplicadores da lei, por certo interessados em defender seu poder discricionário; a criação de um mito de excelência de seus ideais, atribuindo as falhas às desvirtuações ocorridas na prática de sua aplicação; os eufemismos criados pela lei e o desconhecimento ou até o encobrimento das consequências reais de sua aplicação; bem como o fato de ela cumprir funções escusas, diversas das declaradas como seus objetivos ${ }^{550}$.

Consoante já se aventou, tal qual ocorreu em quase todos os países do globo, o Brasil acatou fielmente os preceitos da doutrina da Situação Irregular, sendo criado neste território, em 1923, no Distrito Federal, o primeiro Tribunal especializado nacional.

O Código Mello Matos, de 1927, inaugurou o primeiro conjunto normativo especializado do País. Ele foi assim alcunhado em homenagem a José Cândido Albuquerque de Mello Matos, seu primeiro juiz de menores.

Esse entendimento da questão menoril que se consolida com a entrada em vigor do primeiro Código de Menores perdurará no Brasil, de forma hegemônica, até a aprovação da Constituição Cidadã de 1988.

Durante a ditadura Vargas elevou-se o papel do serviço social, fator que repercutiu no tratamento dispensado aos menores.

O Decreto-lei 3.799/41 foi responsável pela implementação do SAM - Serviço de Assistência ao Menor -, órgão vinculado ao Ministério da Justiça, representativo da máxima intervenção estatal na questão menoril, o qual serviu de influência para a criação, mais tarde, da FUNABEM. Esta

\footnotetext{
${ }^{549} \mathrm{Na}$ América Latina, consoante já se mencionou no presente trabalho, o paradigma da Situação Irregular exerceu total hegemonia por sete décadas, de 1919 a 1990. Neste contexto ressalta García Méndez que "durante sete décadas, as leis de menores foram muito mais que uma epidemia ideológica e mero símbolo de um processo de criminalização da pobreza. As leis de menores foram um instrumento determinante no desenho e execução da política social para a infância pobre”. Cf. GARCÍA MÉNDEZ, Emilio. Infancia, ley y democracia: uma cuestión de justicia. Ciencias Penales: Revista de la Asociación de Ciencias Penales de Costa Rica, Costa Rica, a.10, n. 15, p. 58-71, dez. 1998. p. 69.

${ }^{550}$ GARCÍA MÉNDEZ, Emilio. La Convención Internacional de los Derechos de la Infancia: del menor como objeto de la compasión-represión a la infancia-adolescencia como sujeto de derechos. Capítulo Criminológico, Maracaíbo, n. 18/19, p. 177-193, 1990-1991.
} 
apareceu no cenário nacional como uma instituição que redimiria a questão da menoridade no Brasil, ajudando a disseminar a idéia segundo a qual o Estado, controlado pelos militares, estava atento aos problemas sociais da nação.

Serviu como propaganda política do regime ao nível social ${ }^{551}$.

Essa política de bem-estar do menor consagrou-se com a construção de grandes centros especializados de internamento de jovens ${ }^{552}$ e com a edição do Código de Menores de $1979^{553}$.

Contraditoriamente, essa data, que no Brasil marcou a promulgação de um novo Código de Menores, notadamente influenciado por práticas repressoras e de controle social, foi escolhida pela ONU como o Ano Internacional da Criança ${ }^{554}$.

No País o debate acerca do binômio abandono-delinquência perdurou por todo o século XX. Num primeiro momento, os juristas buscavam respaldo legal para legitimar o controle dos menores que incomodavam o espaço público, instrumento ao qual serviu a edição do Código de Menores de 1927. Já num segundo momento, na década de 1960, nascia uma nova concepção acerca dos sujeitos abandonados e infratores, com a investigação das causas psicossociais dos citados fenômenos, realizada por médicos, juristas, pedagogos, entre outros profissionais ${ }^{555}$.

De qualquer modo, ambos os Códigos “consolidaram tipologias acerca do 'menor' abandonado e do 'menor' infrator, servindo de parâmetros para a internação, exclusão e institucionalização de crianças e adolescentes pertencentes às camadas mais pobres da sociedade" ${ }^{, 556}$.

Cometidos já tantos abusos contra a infância, começa-se a perceber que essa perspectiva de solução para a delinquência juvenil foi falha. Um dos principais erros da tratativa considerada foi compreender o problema dos jovens marginalizados ou em conflito com a lei de forma isolada, sem se considerar as causas sociais que os empurravam

${ }^{551}$ RODRIGUES, Gutemberg Alexandrino. Os filhos do mundo: a face oculta da menoridade (1964-1979). São Paulo: IBCCRIM, 2001. p. 20.

${ }^{552}$ A FEBEM, em São Paulo, surge, como desdobramento da FUNABEM, no ano de 1976. Importante asseverar que "se, ao nível do discurso, a FEBEM nasceu com propósitos de solucionar o problema da criança e do adolescente desvalido, revelaria, na prática, a imersão de um amplo setor social, vivendo sob a égide da repressão, do controle e do adestramento". Cf. RODRIGUES, Gutemberg Alexandrino. Os filhos do mundo: a face oculta da menoridade (1964-1979). São Paulo: IBCCRIM, 2001. p. 20-21.

${ }^{553}$ SPOSATO, Karyna Batista. O Direito Penal Juvenil. São Paulo: Revista dos Tribunais, 2006.

${ }^{554}$ BRETAN, Maria Emília Accioli Nobre. Os múltiplos olhares sobre o adolescente e o ato infracional: análises e reflexões sobre teses e dissertações da USP e da PUCISP (1990 - 2006). 2008. 223f. Dissertação (Mestrado em Criminologia) - Faculdade de Direito, Universidade de São Paulo, [2008].

${ }_{555}^{5 O D R I G U E S, ~ G u t e m b e r g ~ A l e x a n d r i n o . ~ O s ~ f i l h o s ~ d o ~ m u n d o: ~ a ~ f a c e ~ o c u l t a ~ d a ~ m e n o r i d a d e ~(1964-1979) . ~}$ São Paulo: IBCCRIM, 2001.

${ }_{556}^{5}$ RODRIGUES, Gutemberg Alexandrino. Os filhos do mundo: a face oculta da menoridade (1964-1979). São Paulo: IBCCRIM, 2001. p. 274. 
para a delinquência, bem como sem se perceber que excluí-los da sociedade - por meio de sua internação - não era o meio adequado de "recuperá-lo", sendo, diversamente, essencial para ele a mantença do contanto com os demais membros do corpo social ${ }^{557}$.

Como recuperar a sociabilidade do indivíduo afastando-o do contato com os demais em um momento em que seu processo natural de socialização nem sequer havia sido concluído?

Evidenciadas as vicissitudes da doutrina, inicia-se uma conscientização acerca dos malefícios por ela trazidos, movimento crítico, encabeçado também pelas sociedades civis europeias e latino-americanas, que ocorre concomitantemente em diversos países do globo.

Na Argentina, em 1988, Elbert escreveu que "deve-se dar por terminada a ficção legal de que a educação e a tutela legitimam o recorte das garantias constitucionais e de direitos humanos em referência aos menores" ${ }^{\text {,558. }}$.

Logo passam a ser editados inúmeros documentos internacionais objetivando o câmbio do entendimento até então dominante.

As Regras de Beijing, também chamadas de Regras Mínimas das Nações Unidas para a Administração da Justiça de Menores, foram a primeira normativa internacional nesse sentido, aprovada pela ONU em 1985.

Não obstante, a despeito de ter transcendido em muitos aspectos a doutrina da Situação Irregular, precipuamente no que se refere ao estabelecimento de limites para a ingerência do sistema penal e na execução de medidas socioeducativas, ainda conserva certos ideais do sistema anterior $^{559}$.

As Diretrizes das Nações Unidas para a Prevenção da Delinquência Juvenil, datada de 1990, embora tenha se ocupado em traçar importantes políticas sociais para a infância e adolescência, manteve também normas atreladas ao sistema anterior ${ }^{560}$.

557 GIMÉNEZ-SALINAS COLOMER, Esther. Tratamiento jurídico de la delincuencia de menores en España. Doctrina Penal: Teoría y práctica en las ciencias penales, Buenos Aires, v. 4, n.13-16, p. 261-278, 1981.

${ }^{558}$ ELBERT, Carlos Alberto. Menores em situación irregular y proyectos legislativos en la Argentina actual. Doctrina Penal: Teoría y Práctica en las Ciencias Penales, Buenos Aires, v. 11, n. 41-44, p. 443-459, 1988. p. 458.

${ }^{559}$ Podem ser apontadas como resquícios da defesa social as regras 1.2, 1.4, 2.2, 2.3, 5.1, 17.1a. Cf. URIARTE, Carlos E. Control institucional de la niñez adolescencia en infracción: un programa mínimo de contención y límites jurídicos al Sistema Penal Juvenil (las penas de los jóvenes). Montevidéu: Carlos Alvarez, 1999.

${ }^{560}$ Isso pode ser evidenciado, por exemplo, nas regras 1 e 5 . A regra $5 f$, que dispõe acerca da gravidade de se taxar um jovem com rótulos estigmatizantes, utiliza-se indiscriminadamente em seu texto da expressão delinquência juvenil, inadequada justamente por conta da carga negativa que carrega. 
As Regras Mínimas das Nações Unidas para a Proteção dos Jovens Privados de Liberdade, de 1991, estabeleceu a necessidade de se tentar abolir a prisão de jovens; a excepcionalidade e brevidade dessa medida; a obrigatoriedade de informar o interno acerca do tempo durante o qual ele deverá ser recolhido antes dessa medida ser efetivamente tomada; e a postura a ser adotada pelas autoridades em relação a esses adolescentes.

Essas sim refletem melhor as novas concepções garantistas que estão sendo buscadas.

Todavia, no ano de 1989, em Nova Iorque, é que foi aprovado o mais importante documento em benefício dos direitos das crianças e adolescentes, o qual incorporou e inaugurou a doutrina da Proteção Integral, representativa da segunda etapa da especialização dessa Justiça. Nos termos já referidos, pode-se dizer que ele iniciou a etapa positiva do tratamento diferenciado. Trata-se da Convenção das Nações Unidas sobre os Direitos da Criança, com força coercitiva para as nações signatárias, entre as quais estava o Brasil $^{561}$.

A normativa foi ratificada, já naquele momento, por mais de 160 países $^{562}$, incluindo todos os da América Latina, sendo assinada pelo Brasil em 26 de janeiro de 1990 e aprovada pelo Decreto Legislativo 28, de 14 de setembro de $1990^{563}$.

A Convenção prevê de forma organizada e sistemática normas de proteção à criança e ao adolescente que durante toda a história da especialização da Justiça de Menores encontravam-se distribuídas em outros 80 documentos internacionais ${ }^{564}$. Antes dela o único texto universal a tratar da questão foi a Declaração dos Direitos da Criança, de

561 A Convenção das Nações Unidas sobre os direitos da Criança começou a ser redigida em 1979, convencionado como Ano Internacional da Criança, em comemoração aos vinte anos da Declaração Universal dos Direitos da Criança, e demorou dez anos para ser finalizada.

É ela considerada representação da segunda grande mudança ocorrida no trato das crianças e adolescentes, sendo a primeira, consoante já mencionado no presente trabalho, a criação do Tribunal de Menores em Illinois. Cf. GARCÍA MÉNDEZ, Emilio. Política de la infancia/adolescencia en América Latina. Estado, movimiento social y modelo jurídico-institucional: tendencias y perspectivas. Doctrina Penal: Teoría y práctica en las Ciencias Penales, Buenos Aires, a. 14, n. 55/56, p. 479-489, jul./dez. 1991.

${ }_{562}$ Até o ano de 2001, 187 países já haviam ratificado a Convenção.

${ }^{563}$ Apenas dois anos após sua entrada em vigor a Convenção contava com o maior número de ratificações já visto relativamente a um tratado de Direitos Humanos, tendo-se destacado negativamente os Estados Unidos e a Somália pela não aceitação do documento. Importante ainda asseverar que os países que confirmaram a Convenção obrigaram-se também a apresentar ao Comitê dos Direitos da Criança relatórios anuais acerca de sua atuação governamental nessa seara. Cf. MONACO, Gustavo Ferraz de Campos. A Declaração Universal dos Direitos da Criança e seus sucedâneos internacionais: tentativa de sistematização. Coimbra: Coimbra, 2004. Entretanto, apesar de ratificarem a Convenção, nem todos os países elaboraram em curto prazo uma legislação que a contemplasse.

${ }^{564}$ A Convenção, visando oferecer proteção à criança e ao adolescente da forma mais abrangente possível, disciplina as mais diversas situações em que esse cuidado deve ser observado, tais como o direito a educação, a proteção em caso de conflitos armados, em situação de exploração sexual, o direito à saúde, a proteção contra violência, entre outras. 
20 de novembro de 1959, que, no entanto, por sua natureza meramente declaratória, não tinha força vinculante para os Estados ${ }^{565}$.

Ademais, ela consolida um conjunto de legislações internacionais sobre o tema, que se convencionou denominar Doutrina das Nações Unidas de Proteção Integral da Infância, composta, além da própria Convenção, pelos documentos acima mencionados.

Essa novel normativa assenta-se sobre quatro princípios fundamentais: da não discriminação; do direito à vida, à sobrevivência e ao desenvolvimento; do respeito às opiniões da criança e do adolescente; e do interesse superior da criança ${ }^{566}$.

Duas disposições demonstram claramente a mudança de paradigmas que então se realizava: a criança e o adolescente passam a ser considerados sujeitos, não mais objetos de direito, e acaba-se a equiparação entre abandono, delinquência e situação irregular, por meio da diferenciação entre jovens carentes de proteção - vítimas - e autores de condutas proibidas, ofertando-se-lhes, pela primeira vez, tratamento jurídico diferenciado.

Fato é que,

precisamente, a proteção integral quer evitar a construção social que separa os 'menores' das crianças e dirige-se às crianças e adolescentes como sujeitos com direitos humanos originários, com a finalidade de evitar a sua marginalização e de reintegrar os 'menores' em desvantagem ou infractores o mais rapidamente possível no sistema normal da infância e da adolescência ${ }^{567}$.

Reconhece-se, a partir de agora, que as crianças e adolescentes têm os mesmos direitos fundamentais assegurados a toda pessoa humana; têm direito, além disso, a uma proteção integral, bem como a instrumentos que assegurem seu saudável desenvolvimento físico, mental, moral e espiritual, em condições de liberdade e dignidade.

\footnotetext{
565 BARATTA, Alessandro. La situación de la protección del niño en America Latina: líneas de una investigación-acción sobre los derechos de los niños. Capítulo Criminológico, Maracaibo, v. 18-19, p. 159175, 1990-1991.

${ }^{566}$ ALBUQUERQUE, Catarina de. Os direitos da Criança em Portugal e no mundo globalizado: o princípio do interesse superior da criança. Direito das Crianças, Coimbra, n. 3, p. 39-63, 2004. Para Uriarte, pela nova concepção esposada pela Convenção deixa de existir espaço "para a defesa social, como esquema ideológico que orienta a atividade punitiva institucional, assim como tampouco para a construção punitiva das políticas sociais. Em seu lugar, a Convenção aprofunda as garantias ante o sistema penal, do qual obviamente desconfia, e promove, em geral, a mais ampla realização de direitos e necessidades". Cf. URIARTE, Carlos E. Control institucional de la niñez adolescencia en infracción: un programa mínimo de contención y límites jurídicos al Sistema Penal Juvenil (las penas de los jóvenes). Montevidéu: Carlos Alvarez, 1999. p. 160.

${ }^{567}$ BARATTA, Alessandro. Os direitos da criança e o futuro da democracia. In: et al. Perspectivas do Direito no início do século XXI. Coimbra: Coimbra Editora, 1999, p. 73.
} 
Em poucas palavras, a doutrina da Proteção Integral representa o "reconhecimento dos direitos da criança como uma categoria dos direitos humanos" ${ }^{, 568}$.

Trata-se de uma nova definição do papel do Estado e da sociedade civil diante das crianças e adolescentes carentes e também dos autores de atos infracionais ${ }^{569}$.

A ansiada mudança de paradigmas manifestou-se, então, em todos os aspectos da tratativa das crianças e adolescentes, tanto no tocante às políticas destinadas à sua proteção, quanto no que diz respeito às dirigidas à repressão das condutas ilícitas perpetradas por esses sujeitos. Nessa seara, a conquista da Proteção Integral para o adolescente consiste "em protegê-lo da medida e contra a injustiça de sua aplicação"

Assim, pode ser destacado como o maior avanço do novo pensamento o "estabelecimento de um verdadeiro empecilho para a utilização das mais diversas formas coativas, em especial por intermédio de internação, para aquelas crianças e adolescentes vítimas de desamparo social" ${ }^{\text {571 }}$.

Outrossim, foi ela ainda fundamental para a objetivação do direito e das práticas realizadas na seara da infância e juventude, objetivação essa no sentido de oposição à discricionariedade ${ }^{572}$.

O que se evidencia é que "a proteção integral à infância e juventude situa, portanto, o sistema de justiça numa dimensão ético-política de proteger os mais vulneráveis, respeitando seus modos singulares de existência" ${ }^{\circ 73}$.

Importante desvelar o pioneirismo do Brasil, nesse novo contexto de teorização e normatização das questões referentes à infância e juventude.

A doutrina da Proteção Integral foi incorporada à legislação brasileira em 1988 por meio da edição dos artigos 227 e 228 da Constituição Federal - antes mesmo da

\footnotetext{
${ }^{568}$ SOTOMAYOR, Carlos Tiffer. De un Derecho Tutelar a un Derecho Penal MínimoIGarantista: nueva Ley de Justicia Penal Juvenil. Ciencias Penales .Revista de la Asociación de Ciencias Penales de Costa Rica, San José , n. 13, p. 98-109, ago. 1997. p. 99.

${ }^{569}$ LUCCHINI, Riccardo. Le débat brésilien sur la Justice des Mineurs. Déviance et Societé, Liège, v. 15, n. 2, p. 175-186, 1991.

${ }^{570}$ KONZEN, Afonso Armando. Reflexões sobre a medida e sua execução (ou sobre o nascimento de um modelo de convivência do jurídico e do pedagógico na socioeducação). In: ILANUD et al. (Org.). Justiça, adolescente e ato infracional: socioeducação e responsabilização. São Paulo: ILANUD, 2006. p. 343.

${ }^{571}$ SAENZ, Fabiana Eduardo. Política Criminal e limite etário de responsabilização penal. 2008. $218 \mathrm{f}$. Dissertação (Mestrado em Criminologia) - Faculdade de Direito, Universidade de São Paulo, [2008]. p. 123.

${ }^{572}$ GARCÍA MÉNDEZ, Emilio. Infancia, ley y democracia: uma cuestión de justicia. Ciencias Penales: Revista de la Asociación de Ciencias Penales de Costa Rica, Costa Rica, a.10, n. 15, p. 58-71, dez. 1998.

${ }^{573}$ VINCENTIN, Maria Cristina. A questão da responsabilidade penal juvenil: notas para uma perspectiva ético-política. In: ILANUD et al. (Org.). Justiça, adolescente $e$ ato infracional: socioeducação $\mathrm{e}$ responsabilização. São Paulo: ILANUD, 2006. p. 151.
} 
finalização da Convenção -, sendo sua fonte de inspiração a Declaração dos Direitos da Criança da Assembleia das Nações Unidas de $1959^{574}$.

O referido artigo 227 é a primeira norma constitucional já escrita sobre a prioridade absoluta da criança e do adolescente e seus direitos humanos. Na expressão de Saraiva, agora, tornam-se esses sujeitos "a prioridade das prioridades do Estado"

$\mathrm{Na}$ visão de Baratta, representa o citado mandamento a melhor síntese redigida acerca dos princípios que impõe a Convenção ${ }^{576}$. É ele ainda que torna o antigo Código de Menores inconstitucional ${ }^{577}$.

Sobre a importância dessa constitucionalização do direito da infância dissertou García Méndez que

se o direito de menores cumpriu um papel (regressivo) fundamental, entre outras coisas por legitimar as exceções às garantias que o direito constitucional oferece a todos os seres humanos, um novo tipo de direito constitucional inspirado na Convenção abre as portas para uma nova reformulação do pacto social, com todas as crianças e adolescentes como sujeitos ativos do novo pacto ${ }^{578}$.

A Constituição Federal de 1988 assegurou as crianças e adolescentes todos os direitos e garantias conferidos aos adultos, além de outros, a eles específicos, consequência de sua consideração como pessoas em desenvolvimento ${ }^{579}$. Criou, portanto, uma “desequiparação jurídica protetiva” em favor dos sujeitos ainda em desenvolvimento ${ }^{580}$.

$\mathrm{Na}$ esteira do pioneirismo do texto constitucional, o Estatuto da Criança e do Adolescente foi uma das primeiras legislações em âmbito mundial, e a primeira da

\footnotetext{
${ }^{574}$ Nessa incorporação foi fundamental a atuação do movimento chamado A Criança e o Constituinte, movimento da sociedade civil e de milhares de crianças visando a inserção no texto constitucional dos princípios expressos na Declaração dos Direitos da Criança.

${ }^{575}$ SARAIVA, João Batista Costa. Compêndio de Direito Penal Juvenil: adolescente e ato infracional. 3. ed. Porto Alegre: Livraria do advogado, 2006. p. 188.

${ }^{576}$ BARATTA, Alessandro. La situación de la protección del niño en America Latina: líneas de una investigación-acción sobre los derechos de los niños. Capítulo Criminológico, Maracaibo, v. 18-19, p. 159175, 1990-1991.

${ }^{577}$ LUCCHINI, Riccardo. Le débat brésilien sur la Justice des Mineurs. Déviance et Societé, Liège, v. 15, n. 2, p. 175-186, 1991.

${ }^{578}$ GARCÍA MÉNDEZ, Emilio. Infancia, ley y democracia: uma cuestión de justicia. Ciencias Penales: Revista de la Asociación de Ciencias Penales de Costa Rica, Costa Rica, a.10, n. 15, p. 58-71, dez. 1998. p. 69.

579 Dentre as garantias específicas podem ser citadas a imputabilidade penal aos dezoito anos e a excepcionalidade e brevidade da privação de liberdade, as quais serão explicitadas no decorrer do presente trabalho.

${ }^{580}$ MACHADO, Martha de Toledo. Sistema especial de proteção da liberdade do adolescente na Constituição brasileira de 1988 e no estado da criança e do adolescente. In: ILANUD et al. (Org.). Justiça, adolescente e ato infracional: socioeducação e responsabilização. São Paulo: ILANUD, 2006. p. 100.
} 
América Latina, a adotar a doutrina da Proteção Integral. Trata-se, para Baratta, da legislação que melhor acolheu o espírito e a letra da Convenção ${ }^{581}$.

Sua importância está no fato de que "estabeleceu o estado democrático de direito num contexto em que estivera ausente desde a formação histórica do Brasil, abolindo o subjetivismo, o arbítrio, consagrando e dignificando a justiça” ${ }^{, 582}$.

A doutrina da Proteção Integral, consoante já explicitado, garante direitos aos jovens em todas as situações em que eles se encontrem, o que não deixou de ser observado pelo Estatuto da Criança e do Adolescente.

Em seu modelo sistêmico, os direitos e deveres das crianças e adolescentes podem ser agrupados em três conjuntos diversos, denominados também de etapas da tutela estatal, cada qual deles identificado a partir de um prisma de prevenção.

A prevenção primária, representada pelas políticas básicas, tem por escopo assegurar direitos a todas as crianças e adolescentes, indistintamente, tais como saúde, alimentação, habitação, educação, transporte profissionalização e cultura. A prevenção secundária, na qual se inserem as políticas de proteção especial, inclui as medidas de proteção, guarda, renda familiar mínima, atendimento às vítimas de maus tratos, abrigamento, guarda subsidiada, entre outras, destinadas aos sujeitos vitimizados ${ }^{583}$. Por fim, a prevenção terciária é composta pelas políticas socioeducativas, que englobam as sanções aplicáveis aos adolescentes autores de atos infracionais, denominadas de medidas socioeducativas $^{584}$.

É neste último enfoque que se insere o presente trabalho, sendo, por isso, mister o entendimento do novo modelo de responsabilização dos jovens em decorrência da prática de uma conduta ilícita, que neste momento surge.

\footnotetext{
${ }^{581}$ BARATTA, Alessandro. Elementos de un nuevo derecho para la infancia y la adolescência: a proposito del Estatuto del niño y del adolescente de Brasil. Capítulo Criminológico, Maracaibo, v. 23, n. 1, p. 1-18, jan.Ijun. 1995. Para Méndez "a partir da experiência do Brasil, todo o resto das reformas legislativas (com maior ou menor nível de participação social e com uma melhor ou pior técnica jurídica), deixaram de ser esotéricas e clandestinas reuniões de 'peritos' que trabalham nos sótãos dos Ministérios de Justiça, para converterem-se em imensos laboratórios político-sociais de produção jurídica democrática". Cf. GARCÍA MÉNDEZ, Emilio. Infancia, ley y democracia: uma cuestión de justicia. Ciencias Penales: Revista de la Asociación de Ciencias Penales de Costa Rica, Costa Rica, a. 10, n. 15, p. 58-71, dez. 1998. p. 60.

${ }^{582}$ CAMARGO SOBRINHO, Mário. Algumas considerações sobre o adolescente infrator face à legislação nacional e alienígena. Revista Jurídica da Universidade de Franca, Franca, v. 3, n. 4, p. 99-116, mai. 2000. p. 115.

${ }^{583}$ Nesse sentido, relata Passetti que "a partir do momento em que o Estado não preenche a lacuna deixada pelo Mercado, ou seja, a situação de desemprego, carência, abandono e falta de escolaridade, ele pode ser entendido como um violentador, por não cumprir com a responsabilidade que ele próprio se atribuiu: a de tutor de todos os pais". Cf. PASSETT, Edson. Violentados: crianças, adolescentes e justiça. São Paulo: Imaginário. 1995. p. 51.

${ }^{584}$ SPOSATO, Karyna Batista. O Direito Penal Juvenil. São Paulo: Revista dos Tribunais, 2006.
} 
O Estatuto tratou de desmistificar a ideia de que as crianças e adolescentes são seres inferiores e incapazes, fazendo incidir para eles um modelo de imputação no qual a concepção de responsabilidade funda-se na convicção acerca de sua compreensão da ilicitude do ato. O jovem deixa de ser visto como incapaz, erigindo-se, em contrapartida, um modelo de responsabilização mais condizente com as peculiaridades da fase desenvolvimentista em que ele se encontra.

Nesse sentido, passa-se a perceber que

o adolescente não é simplesmente um não adulto, ou um adulto pequeno, é um sujeito diferente considerado em sua peculiar condição social de sujeito em desenvolvimento e dotado de uma autonomia jurídica e social em permanente evolução $^{585}$.

Em observância a essa condição a novel normativa estabeleceu diferenças não apenas no trato de jovens e adultos, mas também de crianças e adolescentes autores de ato infracional. A estas podem ser impostas medidas socioeducativas, àquelas nunca ${ }^{586}$.

Optou-se, no artigo 103 do Estatuto da Criança e do Adolescente, pela tipificação delegada na definição de ato infracional. Trata-se de toda conduta qualificada como crime ou contravenção penal na legislação adulta.

Recordando os ensinamentos da teoria do labelling approach, o ato infracional, tal qual o crime, também representa um comportamento que se convencionou, ou melhor, que os que têm poder para tanto convencionaram taxar como ilícito, não tendo ele nenhuma natureza ontologicamente perversa. No mesmo sentido o seu autor, preconceituosamente denominado delinquente juvenil ${ }^{587}$, é aquele a quem tal rótulo foi atribuído com sucesso, entre os inúmeros sujeitos que adotaram semelhante comportamento.

Note-se, então, que uma análise eminentemente jurídica desses conceitos é sempre falha, uma vez que impede a compreensão de todo substrato social, psicológico, político e criminológico que aí se fundem.

$\mathrm{O}$ ato infracional configura-se como uma

585 BRUÑOL, Miguel Cillero. "Nulla poena sine culpa”. Un límite necesario al castigo penal de los adolescentes. In: GARCÍA MÉNDEZ, Emilio. (Comp.). Adolescentes y responsabilidad penal. Buenos Aires: Ad-Hoc, 2001. p. 71-85. p. 77.

${ }^{586}$ No que se refere à imputabilidade penal, a legislação pátria adotou o critério biológico ou cronológico, estabelecendo uma idade a partir da qual toda pessoa responde penalmente pelos atos ilícitos que praticou, sendo esta fixada em dezoito anos de idade. O mesmo critério também é utilizado para a diferenciação das crianças e dos adolescentes. Nos termos do artigo $2^{\circ}$ do Estatuto criança é a pessoa de até doze anos de idade incompletos, enquanto que o adolescente é o que tem entre doze e dezoito anos de idade.

${ }^{587}$ Bustos Ramírez relata que se devem eliminar as expressões delinquiente e reincidência ao tratar dos jovens, visando a evitar sua estigmatização. Cf. BUSTOS RAMÍREZ, Juan. Perspectivas de un Derecho Penal del Niño. Nueva Doctrina Penal, Buenos Aires, v. A, p. 63-71, 1997. 
realização histórica que não começa e nem termina no adolescente autor de ato infracional. É uma construção política do Estado e tem suas raízes nas políticas econômicas e sociais que são desenvolvidas sob a lógica da inclusão e da exclusão $^{588}$

Ademais, numa outra perspectiva,

entender o adolescente autor de ato infracional como uma realização social que se fecha no próprio adolescente, ou seja, como se a infração fosse uma opção dele diante de um Estado igualitário, é um equívoco que se manifesta nas leituras que entendem o ato infracional numa perspectiva meramente jurídica, encarnada na expressão 'adolescente em conflito com a lei' ${ }^{589}$.

Não se pode ainda perder de vista que esse comportamento ilícito, quando efetivamente praticado, mostra-se apenas como "um dos inúmeros acontecimentos na vida de um adolescente. Portanto, impossível sua compreensão apenas sob a ótica da conduta negativa por ele perpetrada ${ }^{590}$.

A agressividade, muitas vezes inerente à fase de constantes e profundas mutações pela qual passa o adolescente, não significa sempre a temida "delinquência", mas pode ser apenas um momento na vida daquele sujeito ${ }^{591}$. "Sujeito este adolescente, protagonista de um momento de passagem, sem ritos sociais de apoio, lançado aos seus próprios mitos, na eterna tentação de existir, se constituir como sujeito, numa sociedade complexa"592.

Não se pretende defender aqui, sob pena de justificar concepções menoristas, que o adolescente não tem total capacidade de compreender seus atos, sejam eles lícitos ou ilícitos. Todavia, deve-se ter em mente que o jovem encontra-se em um período de sua vida marcado por mutações, de ordem física, sexual, psicológica e social. Suas ações, diversamente do que ocorre com os adultos, cuja personalidade já foi moldada por suas experiências anteriores - mormente pelas ocorridas no período de sua adolescência -, são guiadas pelo princípio do prazer imediato e pela necessidade de sua autoafirmação perante seu grupo específico e a sociedade como um todo.

588 NICODEMOS, Carlos. A natureza do sistema de responsabilização do adolescente autor de ato infracional. In: ILANUD et al. (Org.). Justiça, adolescente e ato infracional: socioeducação e responsabilização. São Paulo: ILANUD, 2006. p. 82.

589 NICODEMOS, Carlos. A natureza do sistema de responsabilização do adolescente autor de ato infracional. In: ILANUD et al. (Org.). Justiça, adolescente e ato infracional: socioeducação e responsabilização. São Paulo: ILANUD, 2006. p. 81.

590 TEIXEIRA, Maria de Lourdes Trassi. Evitar o desperdício de vidas. In: ILANUD et al. (Org.). Justiça, adolescente e ato infracional: socioeducação e responsabilização. São Paulo: ILANUD, 2006.

${ }^{591}$ ROSA, Alexandre Morais da. Introdução crítica ao ato infracional: princípios e garantias constitucionais. Rio de Janeiro: Lumen Juris, 2007.

${ }^{592}$ ROSA, Alexandre Morais da. Introdução crítica ao ato infracional: princípios e garantias constitucionais. Rio de Janeiro: Lumen Juris, 2007. p. 115. 
Também os problemas suportados pelo jovem no ambiente familiar e escolar o afetam de forma particularmente marcante nessa fase, sendo esse fato determinante na escolha de seus comportamentos ${ }^{593}$.

Uma conduta ilícita realizada em determinado momento da juventude, assim, não é a representação do caráter malévolo do seu autor. Em contrapartida, pode ser a extensão de seu conflito consigo mesmo, com o grupo de amigos ou com os pais, de sua necessidade de autoafirmação, da sua busca pelo prazer imediato, entre outros motivos.

São todas essas peculiaridades acima consideradas acerca da especial fase de desenvolvimento do adolescente que justificam a criação de um sistema próprio para sua responsabilização.

O novo modelo pode ser definido como punitivo-judicial ${ }^{594}$ e, portanto, deve observar todas as regras pertinentes à intervenção do poder Judiciário, realizada num Estado Democrático de Direito ${ }^{595}$. Note-se que “o reconhecimento explícito de direitos fundamentais, configura um verdadeiro status jurídico próprio da infância, que se constituirá no limite ao poder punitivo do Estado" ${ }^{\text {. }} 96$.

O que se pretendeu, em realidade, foi construir para esses sujeitos, cujos direitos já haviam sofrido constante violação ao longo da história, um sistema garantista de responsabilização, baseado num modelo de Direito Penal Mínimo.

Nesse diapasão, o sistema de Justiça Juvenil erigiu-se por meio do estabelecimento de princípios específicos, bem como outros gerais, previstos para qualquer pessoa que se encontre em conflito com a lei.

Pertencem exclusivamente à seara juvenil os princípios da condição peculiar de pessoa em desenvolvimento e do melhor interesse do adolescente, ou do interesse superior $^{597}$.

\footnotetext{
${ }^{593}$ ARAUJO, Fernanda Carolina de. Maioridade Penal: aspectos criminológicos. In: SÁ, Alvino Augusto de; SHECAIRA, Sérgio Salomão. Criminologia e os problemas da atualidade. São Paulo: Atlas, 2008. p. 19-50. ${ }^{594}$ HERRERO, César Herrero. Criminologia. 2. ed. Madri: Dykinson, 2001.

${ }^{595}$ O Estatuto da Criança e do Adolescente prevê em benefício dos adolescentes em conflito com a lei um rol de direitos individuais em seus artigos 106 a 109, bem como garantias de direito instrumental nos artigos 110 e 111.

596 BRUÑOL, Miguel Cillero. "Nulla poena sine culpa”. Un límite necesario al castigo penal de los adolescentes. In: GARCÍA MÉNDEZ, Emilio. (Comp.). Adolescentes y responsabilidad penal. Buenos Aires: Ad-Hoc, 2001. p. 71-85. p. 76.

597 A despeito do enfoque dado os princípios no presente trabalho, é certo que ambos devem reger toda interpretação que se faça do Estatuto, não se aplicando apenas às normas de responsabilização atinentes aos jovens em conflito com a lei.
} 
O primeiro supera a categoria discriminadora da menoridade ao estabelecer que cada faixa de desenvolvimento tem suas singularidades, as quais devem ser observadas e respeitadas pelo Estado, pela família e pela sociedade. Em razão disso, existe um processo socioeducativo próprio para os adolescentes, os quais, em virtude do princípio ora em análise, cumprem suas sanções em estabelecimentos distintos dos adultos.

O segundo, por sua vez, quer evitar que as finalidades de mera intimidação e retribuição excedam as preventivo-educativas na imposição e execução de uma medida socioeducativa $^{598}$. Busca-se, por ele, atenuar as restrições de direitos, preferindo a implementação de efetivas políticas sociais, a fim de que diminua a necessidade de imposição de medidas coercitivas.

Esse princípio é enunciado em diversos artigos da Convenção, mais especificamente em oito oportunidades, mas em dois momentos refere-se ele a questões concernentes ao adolescente em conflito com a lei. No artigo 37, alínea c, trata da necessidade, em atendimento do superior interesse, da separação do espaço de reclusão de jovens e adultos, e no artigo 40.2, alínea b, iii, dispõe que o adolescente suspeito da prática de um ato infracional tem direito ao exame de sua causa, sem demora, por uma autoridade competente, independente e imparcial ou por um Tribunal, de forma equitativa, na presença de um defensor e, ao menos que isso se mostre contrário ao seu superior interesse, na presença de seus pais ou representante legal ${ }^{599}$.

Além das mencionadas diretrizes, deve também a ação socioeducativa guiar-se pelas regras penais e processuais garantistas previstas para os adultos. Não é outra a intenção do Código Penal ao dispor em seu artigo 12 que as regras ali disciplinadas aplicam-se aos fatos incriminados por lei especial, se esta não dispuser diversamente, bem como do Estatuto ao anunciar, em seu artigo 103, o conceito de ato infracional, remetendoo ao de crime e de contravenção penal, e em seu artigo 152 que se aplica a esta lei, subsidiariamente, as normais gerais previstas na legislação processual pertinente.

Na visão de Liberati

as garantias processuais penais gerais, estabelecidas na Constituição Federal e nas leis processuais deverão ser utilizadas, subsidiariamente, na apuração do ato infracional, no processo de conhecimento e na execução das medidas aplicadas, naquilo que couber, for possível e adequado. Vale dizer que o infrator menor de

\footnotetext{
${ }^{598}$ SPOSATO, Karyna Batista. Princípios e garantias para um Direito Penal Juvenil Mínimo. In: ILANUD et al. (Org.). Justiça, adolescente e ato infracional: socioeducação e responsabilização. São Paulo: ILANUD, 2006.

${ }^{599}$ ALBUQUERQUE, Catarina de. Os direitos da Criança em Portugal e no mundo globalizado: o princípio do interesse superior da criança. Direito das Crianças, Coimbra, n. 3, p. 39-63, 2004.
} 
18 anos tem todos os direitos dos adultos, compatíveis com a condição peculiar de pessoa em desenvolvimento que ostentam ${ }^{600}$.

Por tudo isso é que o Estatuto da Criança e Adolescente, no que se refere à responsabilização dos jovens em conflito com a lei, pode ser considerado uma legislação penal especial. Nesse sentido asssevera Franco que "essa função finalística do Estatuto o faz elencar-se entre as leis especiais penais, por equiparação, subordinando-se, naquilo que não conflitar com a doutrina da proteção integral, às regras gerais do Código Penal"601 .

Portanto, reitere-se, devem ser dirigidas aos adolescentes em conflito com a lei todas as garantias previstas no Estatuto da Criança e do Adolescente, no Código Penal e nas leis processuais, desde que compatíveis com a proteção integral desses sujeitos. Importante salientar tal posicionamento, uma vez que nos sistemas anteriores o argumento da inimputabilidade, sob um viés conservador e autoritário, serviu para fundamentar

toda e qualquer decisão judicial que prescinde do advogado, do promotor na sua verdadeira função de acusador e das garantias processuais, para alocar de imediato todo e qualquer adolescente em situação-problema proveniente supostamente de uma condição de marginalidade e pobreza, no campo de concentração (FEBEM), visto que para ser prisão seria necessário haver um julgamento com respeito aos princípios do devido processo legal ${ }^{602}$.

Fato é que a nova Justiça Juvenil desvinculou-se da Justiça de menores ao incluir em seu sistema de responsabilização, entre outros princípios, o da legalidade, da intervenção mínima, da lesividade, da humanidade das penas, da proporcionalidade e da culpabilidade, tão caros também ao Direito Penal democrático.

A legalidade, com previsão no artigo $5^{\circ}$, XXXIX, da Constituição Federal e no artigo 40, 2, a, da Convenção, é a representação maior da limitação jurídica ao poder de punir exercido pelo Estado. Destaque-se que é a primeira vez que esta regra primordial em um Estado Democrático de Direito é enunciada em favor da infância e juventude brasileira $^{603}$, revelando-se nessa seara como a obrigatoriedade da definição das condutas que consubstanciam o ato infracional e da determinação de suas consequências jurídicas, quais sejam, as medidas socioeducativas ${ }^{604}$.

\footnotetext{
${ }^{600}$ LIBERATI, Wilson Donizeti. Processo Penal Juvenil: a garantia da legalidade na execução de medida socioeducativa. São Paulo: Malheiros, 2006. p. 96-97.

601 FRANCO, Alberto Silva. Leis Penais Especiais e sua interpretação jurisprudencial. 6. ed. São Paulo:Revista dos Tribunais, 1997. p. 443.

${ }^{602}$ PASSETTI, Edson. Violentados: crianças, adolescentes e justiça. São Paulo: Imaginário. 1995. p. $127-$ 128.

${ }^{603}$ COSTA, Ana Paula Motta. As garantias processuais e o Direito Penal Juvenil como limite na aplicação da medida socioeducativa de internação. Porto Alegre: Livraria do Advogado, 2005.

${ }^{604} \mathrm{~A}$ inferência a esse principio pode também ser verificada no Estatuto, por exemplo, na redação dos artigos 103, que anuncia o que se afigura como ato infracional; 112, no qual se elenca o rol das medidas
} 
A intervenção mínima, prevista no item 17.1, b, das Regras Mínimas das Nações Unidas para a Administração da Justiça da Infância e Juventude, determina que a atuação do sistema de responsabilização previsto no Estatuto deve ser sempre fragmentária e subsidiária. Na visão de Sposato, para a realização desse princípio "faz-se necessária uma efetiva adoção do que se convencionou chamar de Política dos 4Ds: Descriminalização, Diversão - Diversion - Devido Processo Legal e Descriminalização"605, propugnada na teorização do labelling approach.

O princípio da lesividade determina que a punição é legítima apenas quando se insurge contra atos ilícitos efetivamente praticados por um sujeito. Representa, então, nessa seara, a definitiva "expurgação do Direito penal do Autor" ${ }^{606}$, permitindo, assim, ao menos no plano teórico, o banimento das concepções menoristas acerca de delinquência.

A humanidade das penas, disposta nos artigos 37 da Convenção e $5^{\circ}$, XLVII, da Constituição Federal, implica uma necessária racionalidade e proporcionalidade também quando se trata da aplicação de medidas socioeducativas.

A regra da proporcionalidade, implícita na Constituição Federal de 1988, é adotada de forma mitigada pelo Estatuto, visando ao atendimento do princípio maior da Proteção Integral.

Para Gómez Rivero a proporção entre crime e pena comporta duas direções: os atos graves devem receber penalidades graves e os atos leves sanções leves. Entretanto, assevera a autora que na Justiça Penal Juvenil essa primeira via direcional é suprimida: condutas graves não demandam necessariamente penalidades gravosas ${ }^{607}$.

É esse também o pensamento de Shecaira, para quem o período máximo de três anos de internação é representação da mitigação da proporcionalidade nessa seara. Ademais, crê que especialmente na execução das sanções juvenis o abrandamento da

socioeducativas; 114, para o qual a medida só pode ser imposta com a comprovação da autoria e materialidade da infração; e no 189, que assevera que nenhuma sanção juvenil pode ser aplicada se comprovada a inexistência do fato, não haver prova de sua existência, não constituir o fato ato infracional ou não haver prova do adolescente ter concorrido para o fato.

${ }^{605}$ SPOSATO, Karyna Batista. Princípios e garantias para um Direito Penal Juvenil Mínimo. In: ILANUD et al. (Org.). Justiça, adolescente e ato infracional: socioeducação e responsabilização. São Paulo: ILANUD, 2006. p. 260.

${ }^{606}$ SPOSATO, Karyna Batista. Princípios e garantias para um Direito Penal Juvenil Mínimo. In: ILANUD et al. (Org.). Justiça, adolescente e ato infracional: socioeducação e responsabilização. São Paulo: ILANUD, 2006. p. 260.

607 GÓMEZ RIVERO, Maria Carmen. Algunos aspectos de la Ley Orgânica 5/2000, de 12 de enero, reguladora de la responsabilidad penal del menor. Actualidad Penal, Madri, n.10, p. 163-187, 2001. 
proporcionalidade pode ser evidenciado, por demandar a indeterminação da internação, a qual é reavaliada a cada seis meses, no máximo ${ }^{608}$.

Também o princípio da culpabilidade, previsto no artigo 40, 2, b, I, da Convenção, é adotado, todavia de forma relativizada em relação aos adolescentes em conflito com a lei.

Justificando tal atenuação assevera Shecaira que o exame da culpabilidade de adultos e adolescentes deve ter uma reapreciação bastante cuidadosa do operador do direito, tendo em vista a discrepância no grau de desenvolvimento desses sujeitos. A régua das condutas criminais, inflexível no Direito Penal comum, tem de necessariamente ser flexibilizada para os jovens, sob pena de serem cometidos inúmeros erros na apreciação de sua culpabilidade ${ }^{609}$.

Já no plano processual, consigna-se, valem para os adolescentes, entre outros, os princípios da publicidade dos atos processuais penais de apuração de ato infracional; do devido processo legal, composto pelo contraditório e ampla defesa; do devido processo penal, como reflexo do devido processo no âmbito especificamente penal; do pleno e formal conhecimento da atribuição de ato infracional, mediante citação ou meio equivalente; da defesa técnica por advogado, sem a qual o ato será nulo; da assistência judiciária gratuita e integral aos necessitados, na forma da lei; do direito de ser ouvido pessoalmente pela autoridade competente, do qual se extrai a obrigatoriedade da regra do juiz natural; do direito de solicitar a presença dos pais ou responsável em qualquer fase do procedimento; da motivação qualificada dos atos decisórios de natureza penal; da individualização da medida nos termos do art. 112, parágrafo $1^{\circ}$, do Estatuto; da fixação de prazo razoável de duração do processo de apuração de ato infracional; da apreensão em flagrante ou por ordem judicial; bem como da proteção contra a tortura e tratamento desumano ou degradante $e^{610}$.

Portanto, nessa segunda fase - positiva - da especialização da Justiça Juvenil, grandes conquistas foram buscadas e realizadas, mas a luta em defesa das crianças e adolescentes ainda não se encerrou. Esses sujeitos,

que estiveram à parte da cidadania ou da segurança da garantia dos direitos sociais e individuais prometidos pela modernidade, hoje têm no plano normativo seus direitos reconhecidos. No entanto, a dimensão da incerteza contemporânea

\footnotetext{
${ }^{608}$ SHECAIRA, Sérgio Salomão. Sistema de Garantias e o Direito Penal Juvenil. São Paulo: Revista dos Tribunais, 2008.

609 SHECAIRA, Sérgio Salomão. Sistema de Garantias e o Direito Penal Juvenil. São Paulo: Revista dos Tribunais, 2008.

${ }^{610}$ LIBERATI, Wilson Donizeti. Processo Penal Juvenil: a garantia da legalidade na execução de medida socioeducativa. São Paulo: Malheiros, 2006.
} 
relativiza estas conquistas, tornando a tarefa de efetivar direitos, para além da superação histórica, a própria superação da nova ordem contemporânea"611 .

Essa, pois, é a nova luta a ser travada.

\subsubsection{Finalidades das medidas impostas a crianças e adolescentes na história da Justiça especializada}

As doutrinas moralistas de emenda do infrator são as mais antigas, relacionadas à poena medicinalis já defendida por Platão ao mencionar a enfermidade da alma e por São Tomás de Aquino. Podem ser citados também como antigos precursores San Juan Crisóstomo e Clemente XI com a tese de correção dos réus, bem como John Howard, que propôs a transformação dos presídios para que sua estrutura não corrompesse os apenados.

Trata-se das mais puras concepções judaica, católica e religiosa em geral, para as quais, em consonância com o Direito Canônico Medieval, o castigo serviria como instrumento de correção ao que a ele se submetesse ${ }^{612}$.

Desse modo, "estas concepções vêem na pena mais que um mal para quem a sofre, uma medicina para a alma, algo benéfico para o delinquente, com uma função pedagógica",613.

Nota-se, então, que a Igreja exerceu grande influência no trato da questão menoril, utilizando-se de uma metodologia filantropo-caritativa. Essa negativa visão foi, mais tarde, abraçada pelo Estado, quando da instituição de políticas de intervenção destinadas a crianças e adolescentes.

Foi em finais do século XIX que começou a ganhar força a ideia de substituir o Direito Penal do castigo por um Direito Penal de tratamento. Intencionava-se aplicar uma pena que almejasse a melhora e a recuperação daquele que estava desviando-se dos valores cultivados pela sociedade.

Assim, a Escola Positiva italiana pretendeu a substituição da pena por uma medida de segurança e a corrente Correcionalista, especialmente sua vertente espanhola, atribuiu à

\footnotetext{
${ }^{611}$ COSTA, Ana Paula Motta. As garantias processuais e o Direito Penal Juvenil como limite na aplicação da medida socioeducativa de internação. Porto Alegre: Livraria do Advogado, 2005. p. 63.

${ }^{612}$ TELLA, Maria José Falcón; TELLA, Fernando Falcón. Fundamento e finalidade da sanção: existe um direito de castigar? Tradução de Cláudia de Miranda Avena. São Paulo: Revista dos Tribunais, 2008.

${ }^{613}$ TELLA, Maria José Falcón; TELLA, Fernando Falcón. Fundamento e finalidade da sanção: existe um direito de castigar? Tradução de Cláudia de Miranda Avena. São Paulo: Revista dos Tribunais, 2008. p. 222.
} 
sanção finalidades de tratamento do delinquente ${ }^{614}$.

Fato é que esses princípios que colaboraram na gestação do Direito Penal moderno ganharam força após o período das Grandes Guerras, reforçando-se a necessidade de um sistema penal orientado a uma pena-fim. Logo, a pena, não poderia continuar sendo concebida apenas como retribuição.

Nesse momento, a reconstrução dos aparatos de produção exigiu iniciativas dos Estados, os quais se encarregaram também da reconstrução do sistema penal. Assim, verifica-se a ligação da ideologia ressocializadora não apenas com a orientação correcionalista de interpretação da pena, mas também com o modelo de Estado de Bemestar social $^{615}$.

Tal ideologia fez-se evidente no trato menoril, durante a etapa tutelar, tendo reinado aí uma concepção retributivo-expiatória da punição.

Ressocializar, reeducar e profissionalizar eram os objetivos aparentes do sistema, que, entretanto, encobriam seu verdadeiro desígnio de manter sob controle uma parcela delimitada da população ${ }^{616}$.

Em pesquisa aos arquivos da Justiça de Menores da cidade do Rio de Janeiro, entre os anos de 1968 e 1988, Batista encontrou o seguinte parecer, no caso de um jovem que portava drogas:

o menor é componente de família bem constituída, de classe média alta (...) Diante do exposto acima, não vemos a necessidade do menor se submeter a tratamento psicoterápico neste serviço. Acrescentamos ainda que a mãe do menor é assistente social, portanto capaz de lhe dar apoio necessário, no que alias a mesma se comprometeu"617.

Entretanto, em outro caso em que a adolescente também portava drogas, o parecer da Delegacia de Proteção ao Menor foi totalmente diverso:

sua família é totalmente desestruturada; apesar de sua mãe viver com o marido, tem companheiro que costuma levar para dentro de casa quando o marido não

\footnotetext{
${ }^{614}$ MIR PUIG, Santiago. ¿Que queda en pie de la resocialización? Eguzkilore. Cuaderno del Instituto Vasco de Criminología, San Sebastián, n. 2 (ext.), p. 35-41, out. 1989. Na Criminologia correcionalista fala-se da sanção como intervenção. Esta busca a eficácia preventiva como meio de proteção social diante da possibilidade de delitos futuros. Cf. TELLA, Maria José Falcón; TELLA, Fernando Falcón. Fundamento e finalidade da sanção: existe um direito de castigar? Tradução de Cláudia de Miranda Avena. São Paulo: Revista dos Tribunais, 2008.

${ }^{615}$ BERGALLI, Roberto. Garantías, sistema penal y exclusión social: una obra intelectual frente a la quiebra de los principios. In: BAIGÚN, David et al. Estudios sobre Justicia Penal. Buenos Aires: Del Puerto, 2005.

${ }^{616}$ BATISTA, Vera Malaguti S. W. O proclamado e o escondido: a violência da neutralidade técnica. Discursos Sediciosos: crime, direito e sociedade, Rio de Janeiro, v. 2, n. 3, p. 77-86, 1997. p. 82.

${ }^{617}$ BATISTA, Vera Malaguti S. W. O proclamado e o escondido: a violência da neutralidade técnica. Discursos Sediciosos: crime, direito e sociedade, Rio de Janeiro, v. 2, n. 3, p. 77-86, 1997. p. 79.
} 
está (...) Acreditamos que a menor deva ser internada para que receba tratamento e orientação para sua vida futura ${ }^{618}$.

Esses registros apenas ilustram que também no Brasil a doutrina da Situação Irregular servia de instrumento de controle dos pobres e de fiscalização das formas de vida dos menores e de seus familiares.

A ilusão ressocializadora e as metáforas biológicas "mascaram a crueldade dos processos de 'regeneração' através do trabalho obrigatório, da educação e da disciplina”,619.

Outrossim, além da reeducação determinar a intervenção estatal sobre o menor "o tempo educativo orienta o tempo judiciário" ${ }^{\text {620 }}$. Isso porque, dado o caráter corretivo dos tratamentos ofertados aos menores, não se justificam o estabelecimento de limites legal e rigidamente preestabelecidos às exigências individualizadas da correição ${ }^{621}$. Assim,

o critério de fixação da duração temporal da privação de liberdade de criança ou adolescente autor de crime (ou portador de 'desvio de conduta') sob o direito do menor era exclusivamente a cessação da periculosidade e sem qualquer correlação nem com a natureza (gravidade objetiva) do crime praticado ${ }^{622}$.

Evidencia-se, pois, uma intervenção "protetiva" fortemente seletiva, bem como uma função de prevenção de condutas futuras, baseada nas condições de vivência do sujeito e na possibilidade de ele um dia infracionar, e não em atos ilegais concretamente praticados no presente.

É a expressão do mais genuíno Direito Penal do autor, tendo em vista que a condição de vulnerabilidade do jovem é que determinava a necessidade de sua "reeducação", permitindo a imposição, desde logo, de medidas pré-delituais.

Esse sistema, assim, "a partir da negação formal do delito e da pena, realiza uma justificação ideológica da legitimidade das medidas de proteção que se fundamenta na periculosidade e na educação (readaptação social)",623.

${ }^{618}$ BATISTA, Vera Malaguti S. W. O proclamado e o escondido: a violência da neutralidade técnica. Discursos Sediciosos: crime, direito e sociedade, Rio de Janeiro, v. 2, n. 3, p. 77-86, 1997. p. 78.

${ }^{619}$ BATISTA, Vera Malaguti S. W. Difíceis ganhos fáceis: Drogas e Juventude pobre no Rio de Janeiro. Rio de Janeiro: Freitas Bastos, 1998. p. 51.

${ }^{620}$ BARANGER, Thierry; SALAS, Denis. Le juge des enfants fait-il encore autorite? Archive de Politique Criminelle, Paris, n. 30, p. 25-35, 2008. p. 28.

${ }^{621}$ FERRAJOLI, Luigi. Direito e Razão: teoria do Garantismo Penal. Tradução de Ana Paula Zomer Sica et al. 2. ed. São Paulo: Revista dos Tribunais, 2006.

${ }^{622}$ MACHADO, Martha de Toledo. Sistema especial de proteção da liberdade do adolescente na Constituição brasileira de 1988 e no estado da criança e do adolescente. In: ILANUD et al. (Org.). Justiça, adolescente e ato infracional: socioeducação e responsabilização. São Paulo: ILANUD, 2006. p. 97-98.

${ }^{623}$ BRUÑOL, Miguel Cillero. "Nulla poena sine culpa". Un límite necesario al castigo penal de los adolescentes. In: GARCÍA MÉNDEZ, Emilio. (Comp.). Adolescentes y responsabilidad penal. Buenos Aires: Ad-Hoc, 2001. p. 71-85. p. 83. 
Trata-se de uma ideologia meramente preventiva da pena. Em outros termos, uma concepção ressocializadora máxima. Não faz diferença aqui se o delinquente será ou não afetado negativamente por ela, se ele a sinta como um mal, já que o que se busca é a sua melhora, sua recuperação a todo custo, uma vez ser o infrator é encarado como uma pessoa inválida, de capacidade diminuída.

Demonstra-se, desse modo, que a proteção emanada da Igreja e trazida ao mundo jurídico pela teoria correcional, inspiradora da doutrina da Situação Irregular, afastava dos menores as garantias existentes no Direito Penal, uma vez que o discurso ecoante era o de que se objetivava apenas sua proteção.

Por detrás desse discurso benfeitor, evidenciava-se o caráter maximalista e totalizante da doutrina, que conferia ao Estado, em substituição à família, o dever e o direito de educação dos jovens em condições econômicas e sociais desfavoráveis.

Não obstante a ingerência que realizava sobre a vida dos menores em situação irregular, o Estado carecia de legitimidade para a aplicação das medidas tutelares, uma vez que limitava ele, de forma arbitrária, o direito de liberdade e de autodeterminação desse sujeito, sem sequer se importar com seu desejo ou recusa em ser educado, bem como com o direito de seus genitores em terem consigo seus filhos.

Nesse ponto relata Gonçalo Nicolau Bandeira que

o modelo proteccionista ajuda a empurrar os menores para fora da família, misturando crianças em perigo com menores praticantes de um facto qualificado pela lei penal como crime, ao restringir, precisamente, os direitos dos progenitores como o direito a manutenção dos filhos e à sua educação, o que põe em causa, também aqui, a legitimação do Estado ${ }^{624}$.

Era assim, pois, que se realizavam a individualização na execução da pena, a prevenção especial construtiva, a reforma e a correção dos apenados.

É a clara visão de uma concepção repressiva da função pedagógica ${ }^{625}$.

Evidencia-se, diante do exposto, uma justificação eminentemente preventiva especial das reprimendas, em seus aspectos negativo e positivo, sem olvidar, entretanto, da prevenção geral.

\footnotetext{
${ }^{624}$ BANDEIRA, Gonçalo Nicolau Cerqueira Sopas de Melo. O direito de intervenção junto de menores infratores como: direito do facto, direito do autor, ou direito do autor e do facto, direito penal ou direito não penal. Revista Portuguesa de Ciência Criminal, Coimbra, v. 13, n.4, outIdez, 2003. p. 615.

${ }^{625}$ FERRAJOLI, Luigi. Direito e Razão: teoria do Garantismo Penal. Tradução de Ana Paula Zomer Sica et al. 2. ed. São Paulo: Revista dos Tribunais, 2006.
} 
Como as medidas eram consideradas benéficas, ou seja, uma oportunidade dada ao jovem de reeducar-se, afastavam-se de sua aplicação quaisquer garantias, utilizando-o como mero instrumento da vontade estatal.

Por suporem uma concepção do poder de punir como bem metajurídico, consubstanciado na figura do Estado pedagogo tutor ou terapeuta, as doutrinas penais dessa natureza foram as menos liberais e antigarantistas historicamente já concebidas, razão pela qual foram as eleitas para sustentar, além das legislações de menores, o nazismo, os manicômios judiciais soviéticos e as escolas de reeducação da China $\operatorname{popular}^{626}$.

A partir da década de 1970, na Europa, com base nos fundamentos de um Estado Democrático de Direito, começa a ser desenvolvido um modelo diferenciado de disciplina dos jovens em conflito com a lei, marcado por um critério de responsabilidade em substituição ao modelo de proteção explanado.

É também na concepção de um Estado Democrático de Direito que se projetam os fins da pena. Qualquer limitação à liberdade do individuo deve estar justificada pela lei para ser autorizada.

Sob esse novo modelo de responsabilização inaugurado pela doutrina da Proteção Integral iniciou-se grande polêmica no que se refere à determinação das finalidades das medidas socioeducativas.

Tal polêmica foi alimentada em parte pelas próprias legislações que as preveem, as quais se esforçam para ludibriar e mascarar sua real intencionalidade.

Nessa esteira, o Estatuto da Criança e do Adolescente, por exemplo, nem sequer aborda essa problemática, limitando-se a destacar o caráter pedagógico que deve guiar a execução das medidas.

A Exposição de Motivos da Lei Orgânica 5/2000 espanhola enfrentava a nebulosa questão de forma corajosa, no entanto sofreu modificação pela Lei 7/2000 antes mesmo de entrar em vigor, suprimindo-se o artigo que tratava do tema e encarando a medida ora como sancionatória e educativa ora como meramente educativa.

A legislação da Costa Rica, em contrapartida, aclarando a questão, convencionou chamar de sanção a consequência jurídica que suporta o jovem em decorrência da autoria comprovada de um ato infracional. Sotomayor defende ser essa a denominação adequada,

${ }^{626}$ FERRAJOLI, Luigi. Direito e Razão: teoria do Garantismo Penal. Tradução de Ana Paula Zomer Sica et al. 2. ed. São Paulo: Revista dos Tribunais, 2006. 
uma vez que "o direito penal de medidas corresponde a um direito penal de autor e de periculosidade" ${ }^{\prime 627}$.

Tendo em vista a omissão brasileira nesse sentido, diversas correntes de pensamento surgiram com a proposição de elucidar as finalidades das medidas socioeducativas, sendo, inclusive, árdua a tentativa de condensar essas opiniões em conjuntos semelhantes.

Há autores que defendem tratar-se de medidas meramente retributivas, sem nenhum conteúdo pedagógico; outros que consideram sua carga pedagógica e retributiva; ainda outros que o fazem por meio da defesa da existência de um Direito Penal Juvenil. Assim, sem pretensão de exata sistematização, serão apresentadas abaixo as concepções de alguns autores acerca da problemática tratada.

Para $\operatorname{Rosa}^{628}$ deve ser rechaçada qualquer pretensão pedagógica às medidas socioeducativas - cujo conteúdo repressivo é patente - uma vez que seu fundamento é agnóstico.

Defende o autor que somente por meio da rejeição do paradigma pedagógico podese intervir democraticamente, já que aceitar os efeitos ressocializantes das medidas socioeducativas, em sua visão, destrói qualquer pretensão garantista sobre a matéria. Nesse sentido relata que "a resposta estatal, no caso representada pela medida socioeducativa, não pode melhorar, nem piorar o adolescente: é agnóstica. $\mathrm{Na}$ forma de instrumento democrático, pode-se apresentar alternativas, somente. O resto é ranço lombrosiano"629.

Ademais, acredita que ainda hodiernamente as propostas pedagógicas dos programas de execução de medidas socioeducativas, em sua maioria, encontram-se vinculadas às premissas da Criminologia Positivista, cuja pretensão de "domesticar o povo jovem, normalmente ainda crente em mudar o mundo, lutar contra as injustiças, impondo medidas que o façam refletir e adquirir os hábitos da ordem burguesa, é o tom das pomposas propostas pedagógicas" ${ }^{\text {,30. }}$.

\footnotetext{
${ }^{627}$ SOTOMAYOR, Carlos Tiffer. De un Derecho Tutelar a un Derecho Penal MínimolGarantista: nueva Ley de Justicia Penal Juvenil. Ciencias Penales. Revista de la Asociación de Ciencias Penales de Costa Rica, San José , n. 13, p. 98-109, ago. 1997. p. 107.

${ }^{628}$ ROSA, Alexandre Morais da. Introdução crítica ao ato infracional: princípios e garantias constitucionais. Rio de Janeiro: Lumen Juris, 2007.

${ }^{629}$ ROSA, Alexandre Morais da. Introdução crítica ao ato infracional: princípios e garantias constitucionais. Rio de Janeiro: Lumen Juris, 2007. p. 15.

${ }^{630}$ ROSA, Alexandre Morais da. Introdução crítica ao ato infracional: princípios e garantias constitucionais. Rio de Janeiro: Lumen Juris, 2007.
} 
Manifesta-se ainda veementemente contra a existência de um Direito Penal Juvenil. Para Rosa este não pode existir uma vez que a lógica das medidas socioeducativas é completamente diversa da das penas dos adultos: o ato infracional é resultado do processo de acertamento normal dos adolescentes com sua nova realidade social, razão pela qual não pode ser o direito infracional aproximado do Direito Penal.

Garrido de Paula ${ }^{631}$, a despeito de encarar a medida socioeducativa como defesa social e intervenção educativa, repudia solenemente a existência do Direito Penal Juvenil. Para ele,

um dos mais graves equívocos foi destacar parte do Direito da Criança e do Adolescente, aquela que trata da responsabilização do menor de 18 anos de idade em razão da prática de conduta descrita como crime e contravenção penal, e qualificá-la como Direito Penal Juvenil ${ }^{632}$.

Assim, defende que o sistema de responsabilização previsto no Estatuto representa um novo ramo do direito, ao qual não se devem aplicar as regras do Direito Penal, tendo em vista que todas as garantias necessárias ao modelo juvenil são decorrência da doutrina da Proteção Integral.

Sotto Maior Neto ${ }^{633}$ também se posiciona contrariamente ao Direito Penal Juvenil por acreditar que, enquanto o sistema penal é injusto, o proposto pelo Estatuto permite que as injustiças sejam corrigidas por meio de seus regramentos próprios, tais como a previsão da remissão e da não correspondência entre determinado tipo de ato infracional e de medida socioeducativa.

Defende ainda que, embora a pena e a medida sejam respostas estatais a uma conduta ilícita, aquela tem finalidade meramente retributiva e esta eminentemente pedagógica. Nesse sentido relata que,

se para a Justiça Penal pouco importa a transformação do condenado em cidadão de melhor categoria, isso se constitui dever a ser observado pelo sistema de atendimento ao adolescente autor de ato infracional. A medida socioeducativa, mesmo inserida como espécie do gênero sanção, não é nem pode ser confundida com a pena (que também não é gênero e sim espécie)"634.

${ }^{631}$ GARRIDO DE PAULA, Paulo Afonso. Ato infracional e natureza do sistema de responsabilização. In: ILANUD et al. (Org.). Justiça, adolescente e ato infracional: socioeducação e responsabilização. São Paulo: ILANUD, 2006.

${ }^{632}$ GARRIDO DE PAULA, Paulo Afonso. Ato infracional e natureza do sistema de responsabilização. In: ILANUD et al. (Org.). Justiça, adolescente e ato infracional: socioeducação e responsabilização. São Paulo: ILANUD, 2006. p. 33.

${ }^{633}$ SOTTO MAIOR NETO, Olympio de Sá. Garantias penais do adolescente autor de ato infracional. In: ILANUD et al (Org.). Justiça, adolescente e ato infracional: socioeducação e responsabilização. São Paulo: ILANUD, 2006.

${ }^{634}$ SOTTO MAIOR NETO, Olympio de Sá. Garantias penais do adolescente autor de ato infracional. In: ILANUD et al (Org.). Justiça, adolescente e ato infracional: socioeducação e responsabilização. São Paulo: ILANUD, 2006. p. 146. 
Em opinião consonante Gomes Neto ${ }^{635}$ crê que não há compatibilidade entre o modelo proposto pelo Estatuto e um Direito Penal Juvenil, tendo em vista que as medidas socioeducativas - sanções de caráter pedagógico - não se confundem com as penas, que são somente uma das formas de sanção. Acredita, outrossim, que a doutrina na Proteção Integral não recepciona a prescrição penal e o Direito Penal Juvenil, pois eles buscam apenas deixar em segundo plano os postulados que a embasam.

Romera $^{636}$ também propõe que não sejam aplicadas ao Estatuto as regras pertencentes ao Código Penal, ao Código de Processo Penal ou à Lei de Execuções Penais no tocante à aplicação e à execução das medidas socioeducativas, uma vez que acredita que o Estatuto normatizou suficientemente tais procedimentos.

Não obstante a visão dos mencionados juristas, há outros, em oposição, que pregam a existência de um modelo de Direito Penal Juvenil, dada a proximidade entre o sistema de responsabilização previsto no Estatuto da Criança e do Adolescente e o disposto no Código Penal.

Saraiva ${ }^{637}$ expressa essa sua convicção já no título de sua obra Compêndio de Direito Penal Juvenil: adolescente e ato infracional. Para ele, tem a medida socioeducativa natureza penal juvenil. Penal enquanto modelo de responsabilização, limitado pelas garantias expressas no ordenamento jurídico. Juvenil enquanto legislação especial, nos termos expressos pelo art. 228 da Constituição Federal, com nítida finalidade educativa, sem desprezar sua eficiente carga retributiva e conseqüente reprovabilidade da conduta sancionada ${ }^{638}$.

Em semelhança ao referido autor Sposato ${ }^{639}$, Shecaira ${ }^{640}$ e Costa ${ }^{641}$ também se utilizam da expressão Direito Penal Juvenil no título de suas obras, elucidando de antemão suas crenças sobre o tema.

Para Sposato a natureza penal da medida socioeducativa não lhe retira "a tarefa e o desafio pedagógico que se colocam para a Justiça da Infância e Juventude e para os

${ }^{635}$ GOMES NETO, Gercino Gerson. O adolescente autor de ato infracional frente aos princípios e garantias do Estatuto da Criança e do Adolescente. Revista do ILANUD, São Paulo, n. 14, p. 43-53, 2001.

${ }^{636}$ ROMERA, Mário. Uma regressão do (no) Estatuta da Criança e do Adolescente (ECA). Revista do Ministério Público, Porto Alegre, n. 46, p. 209-219, jan./mar. 2002.

${ }^{637}$ SARAIVA, João Batista Costa. Compêndio de Direito Penal Juvenil: adolescente e ato infracional. 3. ed. Porto Alegre: Livraria do advogado, 2006.

${ }^{638}$ SARAIVA, João Batista Costa. Compêndio de Direito Penal Juvenil: adolescente e ato infracional. 3. ed. Porto Alegre: Livraria do advogado, 2006. p. 70-71.

${ }^{639}$ SPOSATO, Karyna Batista. O Direito Penal Juvenil. São Paulo: Revista dos Tribunais, 2006.

${ }^{640}$ SHECAIRA, Sérgio Salomão. Sistema de Garantias e o Direito Penal Juvenil. São Paulo: Revista dos Tribunais, 2008.

${ }^{641}$ COSTA, Ana Paula Motta. As garantias processuais e o Direito Penal Juvenil como limite na aplicação da medida socioeducativa de internação. Porto Alegre: Livraria do Advogado, 2005. 
programas de atendimento socioeducativo" ${ }^{\circ 42}$.

Na visão de Shecaira, tal qual a pena, a medida socioeducativa representa uma ação interventiva do Estado na esfera de disposição do indivíduo, tendo esta, pois, caráter de sanção. E continua o autor dizendo que,

ao se afirmar que a medida sócio-educativa tem caráter de sanção, não se quer com isso fazer com que o adolescente tenha o que há de pior no sistema punitivo do adulto - a punição em cárceres que deixam perplexos qualquer observador imparcial, dado o estado das prisões brasileiras -, muito menos fazer com que a sanção sócio-educativa, que guarda visão educacional e pedagógica, tenha um conteúdo meramente retributivo, o que acontece na maioria das penas privativas de liberdade. Ao contrário, preconiza-se a humanização das respostas institucionais, fazendo-se com que a visão dominante entre muitos operadores do direito - deve-se punir para proteger o próprio adolescente - encontre na brevidade e na excepcionalidade seus parâmetros ${ }^{643}$.

Costa, por sua vez, assevera que, em virtude da informalidade com que foram tratados os direitos conquistados pelas crianças e adolescentes e a violação ao princípio da legalidade como partes integrantes de sua história, é mais adequado reconhecer e efetivar o Direito Penal Juvenil do que negar sua existência ${ }^{644}$.

Silva explicita seu posicionamento favorável ao Direito Penal Juvenil por meio dos seguintes dizeres:

não defendo a carcerização do sistema sócio-educativo. Muito menos medidas meramente retributivas. Ao contrário, ao invocar o Direito penal, preconizo a humanização das respostas, as alternativas à privação da liberdade, a descriminalização e a despenalização - o Direito Penal Mínimo ${ }^{645}$.

Assevera, ademais, que do ponto de vista jurídico as medidas socioeducativas têm finalidades retributivas - porque são respostas à prática de um ato infracional -, pedagógicas - porque têm caráter eminentemente educativo - e repressivas - porque são meio de fazer cessar, impedir o cometimento das infrações.

Para Brancher e Aguinsky ${ }^{646}$ as novas concepções acerca do Direito Penal Juvenil serviram para limitar as arbitrariedades praticadas no sistema juvenil.

\footnotetext{
${ }^{642}$ SPOSATO, Karyna Batista. Princípios e garantias para um Direito Penal Juvenil Mínimo. In: ILANUD et al. (Org.). Justiça, adolescente e ato infracional: socioeducação e responsabilização. São Paulo: ILANUD, 2006. p. 254.

${ }^{643}$ SHECAIRA, Sérgio Salomão. Sistema de Garantias e o Direito Penal Juvenil. São Paulo: Revista dos Tribunais, 2008. p. 190.

${ }^{644}$ COSTA, Ana Paula Motta. As garantias processuais e o Direito Penal Juvenil como limite na aplicação da medida socioeducativa de internação. Porto Alegre: Livraria do Advogado, 2005.

${ }^{645}$ SILVA, Antônio Fernando do Amaral e. O Estatuto da Criança e do Adolescente e o sistema de responsabilidade penal juvenil ou o mito da inimputabilidade penal. In: ILANUD et al. (Org.). Justiça, adolescente e ato infracional: socioeducação e responsabilização. São Paulo: ILANUD, 2006. p. 49.

${ }^{646}$ BRANCHER, Leoberto; AGUINSKY, Beatriz. Juventude, crime e justiça: uma promessa impagável? In: ILANUD et al. (Org.). Justiça, adolescente e ato infracional: socioeducação e responsabilização. São Paulo: ILANUD, 2006.
} 
Bustos Ramírez, ${ }^{647}$ adepto também do Direito Penal Juvenil, afirma que, qualitativamente, pena e medida socioeducativa são iguais, sendo que a finalidade educativa desta não muda sua natureza coercitiva e de restrição de direitos. Aliás, para o autor, a própria faculdade reformadora que se prega em relação a esses inimputáveis é Direito Penal.

Fato é que atualmente, aceitando ou não o subsistema do Direito Penal Juvenil, a maioria dos teóricos associa à medida um caráter penal, aflitivo, independentemente de sua finalidade pedagógica.

Assim o é também para Nicodemos ${ }^{648}$ Liberati $^{649}$, Frasseto ${ }^{650}$, entre outros.

Nesse diapasão destaca García Méndez que a negação da responsabilidade penal dos adolescentes representa uma hipócrita ou ingênua reação à sua caracterização como sujeitos de direitos e responsabilidades ${ }^{651}$.

De qualquer modo, para o jovem a consequência jurídica de sua infração significa sempre uma declaração judicial de perda, pela restrição ou privação de liberdade ${ }^{652}$.

Portanto, qualquer que seja o posicionamento adotado, mister que o juiz dê-se conta de que "sua decisão gera efeitos inexoráveis nos envolvidos (adolescente, vítima etc.). Não é uma atividade lúdica, nem desprovida de uma função na estrutura social”653.

Ademais, na execução das medidas socioeducativas - impostas apenas como último recurso - deve-se buscar incessantemente a incitação da autonomia do sujeito e não sua normatização por meio de uma proposta pedagógica padronizada. Deve-se buscar sempre sua emancipação e não sua aniquilação ${ }^{654}$.

\footnotetext{
${ }^{647}$ BUSTOS RAMÍREZ, Juan. Hacia la desmitificación de la facultad reformadora de menores: por um derecho penal de menores. In:____ (Dir.). Un Derecho Penal del Menor. Santiago: Conosur, 1992.

648 NICODEMOS, Carlos. A natureza do sistema de responsabilização do adolescente autor de ato infracional. In: ILANUD et al. (Org.). Justiça, adolescente e ato infracional: socioeducação e responsabilização. São Paulo: ILANUD, 2006. p. 61-85.

${ }^{649}$ LIBERATI, Wilson Donizeti. Processo Penal Juvenil: a garantia da legalidade na execução de medida socioeducativa. São Paulo: Malheiros, 2006.

${ }^{650}$ FRASSETO, Flávio Américo. Execução da medida sócio-educativa de internação: primeiras linhas de uma crítica garantista. In: ILANUD et al. (Org.). Justiça, adolescente e ato infracional: socioeducação e responsabilização. São Paulo: ILANUD, 2006.

${ }^{651}$ GARCÍA MÉNDEZ, Emilio. Evolución historica del derecho de la infancia: Por que uma historia de los derechos de la infância? In: ILANUD et al. (Org.). Justiça, adolescente e ato infracional: socioeducação e responsabilização. São Paulo: ILANUD, 2006.

${ }^{652}$ KONZEN, Afonso Armando. Reflexões sobre a medida e sua execução (ou sobre o nascimento de um modelo de convivência do jurídico e do pedagógico na socioeducação). In: ILANUD et al. (Org.). Justiça, adolescente e ato infracional: socioeducação e responsabilização. São Paulo: ILANUD, 2006. p. 343.

${ }^{653}$ ROSA, Alexandre Morais da. Introdução crítica ao ato infracional: princípios e garantias constitucionais. Rio de Janeiro: Lumen Juris, 2007.

${ }^{654}$ ROSA, Alexandre Morais da. Introdução crítica ao ato infracional: princípios e garantias constitucionais. Rio de Janeiro: Lumen Juris, 2007.
} 
$\mathrm{O}$ adolescente tem direito de exercer sua liberdade como bem quiser. Logo, não se pode aceitar que uma medida socioeducativa pretenda reformar ou reeducar o adolescente, a não ser que ele tenha por isso demandado ${ }^{655}$. Em outros termos pode-se dizer que "a educação não se impõe (em desrespeito à autonomia individual), se propõe" ${ }^{\text {656 }}$.

Utilizando-se das lições de Ferrajoli pode-se defender que qualquer tratamento penal direcionado à alteração coercitiva da pessoa com fins de recuperação ou de integração social afeta a dignidade do sujeito e desrespeita as diversidades e a tolerância de qualquer subjetividade humana $^{657}$.

Desse modo, a necessidade ou não de ressocialização não pode ser o fundamento único da pena. Esse fim não pode oferecer uma justificação global à reprimenda ${ }^{658}$.

A medida socioeducativa, então, tem de ser entendida tal como ela é. Trata-se de uma sanção imposta a alguns dos jovens praticantes de determinado ilícito - os quais foram capturados pelo sistema, sempre seletivo - visando a defender a sociedade das “condutas criminosas" por meio da prevenção geral e da educação e ressocialização do infrator.

\subsection{ESPÉCIES DE MEDIDAS SOCIOEDUCATIVAS}

Atualmente o rol taxativo de medidas socioeducativas encontra-se previsto no artigo 112 do Estatuto da Criança e do Adolescente, sendo sua imposição autorizada somente quando restarem cabalmente comprovadas, por meio do procedimento específico previsto para aqueles que ainda não atingiram a maioridade penal, a autoria e a materialidade de um ato infracional.

Arrola o citado dispositivo legal seis medidas socioeducativas. A advertência, a reparação do dano, a liberdade assistida e a prestação de serviços à comunidade são as sanções cumpridas em regime aberto. Em contrapartida, a semiliberdade e a internação são as executadas em meio fechado.

\footnotetext{
${ }^{655}$ ROSA, Alexandre Morais da. Aplicando o ECA: felicidade e perversão sem limites. Revista Brasileira de Ciências Criminais, São Paulo, v. 14, n. 58, p. 15-28, jan./fev. 2006.

${ }^{656}$ FRASSETO, Flávio Américo. Esboço de um roteiro para aplicação das medidas socioeducativas. Revista Brasileira de Ciências Criminais, São Paulo, a. 7, n. 26, p. 159-195, abr./jun. 1999. p. 166.

${ }^{657}$ FERRAJOLI, Luigi. Direito e Razão: teoria do Garantismo Penal. Tradução de Ana Paula Zomer Sica et al. 2. ed. São Paulo: Revista dos Tribunais, 2006.

${ }^{658}$ MIR PUIG, Santiago. ¿Que queda en pie de la resocialización? Eguzkilore. Cuaderno del Instituto Vasco de Criminología, San Sebastián, n. 2 (ext.), p. 35 a 41, out. 1989.
} 
Importante asseverar que a execução dessas medidas deve reger-se pelo princípio da progressividade, como corolário da condição peculiar de pessoa em desenvolvimento, da excepcionalidade e da brevidade. Por conseguinte, deve ela ser realizada sempre observando a viabilidade de o jovem progredir para uma medida menos restritiva, no espaço temporal mais breve possível.

Tendo em vista a necessidade de integração entre os órgãos públicos e a sociedade para o sucesso dos programas de cumprimento de medidas socioeducativas, aventada pelo próprio Estatuto, as cumpridas em meio aberto devem ser executadas pelos municípios, facilitando-se, assim, essa aproximação ${ }^{659}$. Já no que se refere às medidas executadas em meio fechado, devem os Estados se encarregar de sua realização.

\subsubsection{Advertência}

A advertência, que encontra embasamento legal no artigo 115 do Estatuto da Criança e do Adolescente, era também prevista no artigo 175 do Código Mello Matos e no artigo 14, I, do Código de Menores.

É a medida mais branda entre as disciplinadas na legislação específica e consiste numa entrevista do adolescente com o Juiz - numa audiência admonitória -, reduzida a termo e assinada, na qual ele é repreendido pela conduta infracional praticada. Trata-se, portanto, de medida de cunho moral, que visa a coibir a recidiva do jovem.

É aplicada nos casos de menor gravidade, cometidos sem violência ou grave ameaça à pessoa e envolvendo, geralmente, adolescentes sem antecedentes na Vara da Infância e Juventude. Ao contrário do que ocorre com as demais sanções, é aplicável quando houver prova da materialidade e apenas indícios suficientes de autoria, nos termos do artigo 114, parágrafo único, do Estatuto.

Note-se que, tratando-se de medida de caráter sancionatório, sua aplicação sem a observância dos princípios da legalidade e do devido processo legal é inconstitucional.

Em crítica ao mencionado mandamento assevera Saraiva que

não é possível advertir quem nada admite, ou aquele de quem não se prova que tenha participado do fato. Se nada admite, não há do que ser advertido [...]

\footnotetext{
${ }^{659}$ Não obstante a citada exigência descentralizadora estatutária, em muitos municípios tais programas não foram organizados, sendo as reprimendas executadas precariamente pelas equipes técnicas dos juizados. Cf. COSTA, Ana Paula Motta. As garantias processuais e o Direito Penal Juvenil como limite na aplicação da medida socioeducativa de internação. Porto Alegre: Livraria do Advogado, 2005.
} 
O sistema de Justiça da Infância adotou o modelo do Direito Penal da Ação a partir do princípio da Reserva Legal e não se conforma com atitudes aptas a ressuscitar o velho Direito Penal do Autor, típico de ordens totalitárias ${ }^{660}$.

$\mathrm{O}$ ordenamento jurídico penal brasileiro não prevê penas exatamente nesses moldes. No entanto, assemelha-se, em seus objetivos e formalidades, à audiência admonitória de suspensão condicional da pena, prevista nos artigos 703 do Código de Processo Penal e 160 da Lei de Execuções Penais.

\title{
3.3.2. Reparação do dano
}

No Código de Menores a obrigação de reparar o dano encontrava-se prevista no artigo 103, não como medida sancionatória propriamente dita, mas como seu efeito secundário.

Atualmente disciplinada no artigo 116 do Estatuto da Criança e do Adolescente, é cabível quando a infração praticada pelo adolescente gerar gravames patrimoniais à vítima, apresentando-se, assim, como uma forma de compensação que deve ser realizada pelo próprio infrator, e não por seus genitores. Outrossim, a medida tem o fito de despertar o senso de responsabilidade do jovem acerca do bem alheio.

Por ela pode ser determinado que o adolescente restitua a coisa, ressarça o dano experimentado ou que compense, por outra forma, o prejuízo suportado pela vítima ${ }^{661}$.

Não obstante tenha o condão de despertar o senso de responsabilidade do jovem em relação ao bem alheio, quando efetivamente por ele exercida a reparação, tal medida não é imune a críticas.

Na visão de Sá a reprimenda

\begin{abstract}
constitui reparação civil, travestida de sanção penal, sendo absolutamente inócua, pois a legítima preocupação com a situação da vítima é atendida mais facilmente com a obtenção da indenização junto ao cível. Em relação aos adolescentes, a medida é invariavelmente suportada por terceiros, especialmente os pais, gerando ao autor autêntica sensação de impunidade, além de afrontar o princípio penal da responsabilidade pessoal ${ }^{662}$.
\end{abstract}

\footnotetext{
${ }^{660}$ SARAIVA, João Batista Costa. Compêndio de Direito Penal Juvenil: adolescente e ato infracional. 3. ed. Porto Alegre: Livraria do advogado, 2006. p. 157.

${ }^{661}$ COSTA, Ana Paula Motta. As garantias processuais e o Direito Penal Juvenil como limite na aplicação da medida socioeducativa de internação. Porto Alegre: Livraria do Advogado, 2005.

${ }^{662}$ SÁ, Sidnei Boccia Pinto de Oliveira. Medidas sócio-educativas e sanções penais. De Jure: Revista Jurídica do Ministério Público do Estado de Minas Gerais, Belo Horizonte, n. 6, p. 179-199, jan./jun. 2006. p. 183.
} 
No âmbito penal assemelha-se à pena restritiva de direitos de reparação de danos prevista no artigo 45 , parágrafo $1^{\circ}$, do Código Penal e ao efeito genérico da condenação disciplinado no artigo 91, I, do mesmo diploma.

\subsubsection{Prestação de serviços à comunidade}

É uma das grandes inovações do Estatuto da Criança e do Adolescente, inserida em seu artigo 117, já que tal modalidade de reprimenda não era prevista nas legislações menoris anteriores ${ }^{663}$.

A despeito de sua imprevisão a medida era concebida, em algumas situações, no Código de Menores, como uma das regras de conduta fixadas pelo magistrado no cumprimento da liberdade assistida ${ }^{664}$.

Na prestação de serviços à comunidade o adolescente é compelido a realizar tarefas de interesse geral, gratuitamente, as quais devem ser condizentes com suas necessidades sociais, respeitados seus horários de estudo e trabalho.

Seu forte apelo comunitário permite que a sociedade se conscientize da situação vivenciada por esses jovens e lhes oferte uma experiência da vida comunitária saudável.

Pode ser fixada pelo período máximo de seis meses, por até oito horas semanais e ser cumprida em escolas, hospitais ou organizações comunitárias ou governamentais, conveniadas às Varas da Infância e Juventude.

Logo, a medida ora em análise pode ser caracterizada por ser uma tarefa que pode traduzir-se em trabalho, atividade física ou mental; de realização não remunerada; que desperta o interesse da sociedade e na qual as aptidões do jovem devem ser observadas e respeitadas $^{665}$.

O trabalho executado não pode envolver, por clara afronta ao dever estatal de proteção integral dos jovens, a realização de atividades violentas e discriminatórias; vexatórias ou constrangedoras; não podendo ainda tratar-se de trabalho noturno, perigoso,

\footnotetext{
${ }^{663}$ Essa modalidade de sanção foi introduzida no ordenamento jurídico nacional durante a reforma da parte geral do Código Penal ocorrida no ano de 1984.

${ }^{664}$ FERREIRA, Luiz Antonio Miguel. Execução das medidas socioeducativas em meio aberto: prestação de serviços à comunidade e liberdade assistida. In: ILANUD et al. (Org.). Justiça, adolescente e ato infracional: socioeducação e responsabilização. São Paulo: ILANUD, 2006.

${ }^{665}$ LIBERATI, Wilson Donizeti. Execução de medida socioeducativa em meio aberto: prestação de serviços à comunidade e liberdade assistida. In: ILANUD et al. (Org.). Justiça, adolescente $e$ ato infracional: socioeducação e responsabilização. São Paulo: ILANUD, 2006.
} 
insalubre, penoso ou realizado em locais prejudiciais à formação e desenvolvimento físico, psíquico moral e social do jovem.

O adolescente é encaminhado à entidade na qual prestará serviço após seu comparecimento a uma audiência admonitória, na qual o magistrado irá orientá-lo acerca do cumprimento da medida, destacar suas responsabilidades e tarefas que deverá cumprir.

Finda a prestação, realiza-se uma audiência de encerramento na qual são analisados os relatórios produzidos pela entidade executora.

A medida, em cotejo com as executadas em meio fechado, oferece inúmeras vantagens ao jovem e ao Estado, uma vez que além de ser cumprida em meio aberto tem fácil controle e baixo custo.

De acordo com dados da FEBEM, em junho de 1997 a instituição gastou, por mês, a média de $\mathrm{R} \$ 918,00$ com cada interno. Por outro lado, no Rio Grande do Sul, gastou-se uma média de $\mathrm{R} \$ 653,41$, por ano, com cada adolescente submetido a medida de prestação de serviços à comunidade. Note-se, relevando-se as diferenças no custo de vida em cada Estado, que um jovem em privação de liberdade pode custar para os cofres públicos, por mês, mais do que um em prestação de serviços à comunidade custa por ano ${ }^{666}$.

À luz desses dados, Castro conclui que "gasta-se muito para tornar o jovem infrator mais violento, e pouco se faz para que a prestação de serviços seja mais aplicada"667.

Diante do exposto sobre a medida, evidente, pois, a semelhança dessa prestação de serviços à comunidade com a pena restritiva de direitos, de mesmo nome, prevista no artigo 43, IV, do Código Penal e regulamentada nos artigos 149 e 150 da Lei de Execuções Penais.

\subsubsection{Liberdade assistida}

A medida já era disciplinada no artigo 100 do Código Mello Matos, com o nome de liberdade vigiada, e no artigo 38 do Código de Menores, sendo que hoje o é no artigo 118 do Estatuto da Criança e do Adolescente.

\footnotetext{
${ }^{666}$ CASTRO, Ana Márcia de Souza. Alternativas ao jovem infrator. Revista do ILANUD, São Paulo, n. 12, p. 17-24, 1998.

${ }^{667}$ CASTRO, Ana Márcia de Souza. Alternativas ao jovem infrator. Revista do ILANUD, São Paulo, n. 12, p. 17-24, 1998. p. 24.
} 
Trata-se da mais grave das medidas restritivas de direitos, em meio aberto, prevista na legislação especial.

A liberdade assistida é recomendada para casos de cometimento de infração de média gravidade, quando se identifica que uma medida mais branda poderia ser ineficaz. Nomeia-se um orientador ${ }^{668}$, o qual deve servir como uma figura de referência do jovem, que fica encarregado de acompanhá-lo e auxiliá-lo, inclusive fiscalizando sua matrícula e frequência a um estabelecimento de ensino educacional ou profissionalizante, de diligenciar sua inscrição no mercado de trabalho, de promover socialmente o jovem e sua família, inclusive inscrevendo-os em programa oficial de auxílio ou assistência social, bem como de elaborar relatório do acompanhamento realizado.

Em suma, o orientador deve "garantir a efetivação dos direitos fundamentais consagrados ao adolescente na Constituição Federal (art. 227) e no ECA (art. $4^{\circ}$ ), garantindo-lhe sua condição de cidadão"669.

Trata-se de um programa de atendimento oferecido pelo poder público ou por entidade não-governamental, cumprido pelo jovem em meio aberto, com o objetivo de reorganizar sua vida na família, escola e comunidade ${ }^{670}$.

É certo que o aproveitamento educativo dessa reprimenda depende do preparo e empenho do orientador, sem o qual nenhum efeito benéfico se produzirá. Nesse sentido, "muito há que se fazer em termos práticos, cujo atendimento, à maioria das vezes, deixa a desejar, resumido, no mais, a periódicas visitas por parte do adolescente ao órgão tutelar e à colheita de assinaturas em certo período",671.

Para alguns doutrinadores, quando adequadamente aplicada e executada, é a medida que alcança o maior sucesso ${ }^{672}$.

${ }^{668} \mathrm{O}$ Estatuto da Criança e do Adolescente não dispõe acerca dos requisitos para que uma pessoa possa tornar-se orientadora da medida de liberdade assistida, referindo-se apenas que deve ser pessoa capacitada, recomendada por entidade ou programa de atendimento.

${ }^{669}$ FERREIRA, Luiz Antonio Miguel. Execução das medidas socioeducativas em meio aberto: prestação de serviços à comunidade e liberdade assistida. In: ILANUD et al. (Org.). Justiça, adolescente e ato infracional: socioeducação e responsabilização. São Paulo: ILANUD, 2006. p. 411.

${ }^{670}$ LIBERATI, Wilson Donizeti. Execucao de medida socioeducativa em meio aberto: prestação de serviços à comunidade e liberdade assistida. In: ILANUD et al. (Org.). Justiça, adolescente e ato infracional: socioeducação e responsabilização. São Paulo: ILANUD, 2006.

${ }^{671}$ JUNQUEIRA, Ivan de Carvalho. Do ato infracional à luz dos Direitos Humanos. Campinas: Russell, 2009. p. 88 .

${ }^{672}$ Nesse sentido ver: COSTA, Ana Paula Motta. As garantias processuais e o Direito Penal Juvenil como limite na aplicação da medida socioeducativa de internação. Porto Alegre: Livraria do Advogado, 2005 e SARAIVA, João Batista Costa. Compêndio de Direito Penal Juvenil: adolescente e ato infracional. 3. ed. Porto Alegre: Livraria do advogado, 2006. 
Note-se que a liberdade assistida possui forte apelo social, uma vez que visa a preparar o adolescente para a reintegração social sadia e harmoniosa, por meio do estudo e do trabalho, bem como do estreitamento de seus vínculos familiares, sociais e éticos.

Para Gómez Rivero

esta medida, cujo uso potencializa-se a partir dos anos 70, combina dois aspectos que a fazem especialmente atrativa: o primeiro, o fato de permitir um acompanhamento individualizado do menor, que tenha em conta suas necessidades, suas deficiências pessoais e sócio-familiares desde uma perspectiva integral, e segundo, o dado de que respeita sua liberdade com o conseguinte aumento das possibilidades de que se integre de novo em sociedade ${ }^{673}$.

Trata-se, ademais, de uma medida bastante flexível que pode facilmente ser adaptada às necessidades e à disponibilidade de tempo do jovem individualmente considerado.

Entretanto,

a manutenção de adolescentes infratores adequadamente assistidos, comprometendo-se a sociedade com esses programas, alcança sucesso na medida em que não se faça da medida de LA um simulacro de atendimento, como muitas vezes se fez em relação aos imputáveis colocados em sursis ${ }^{674}$.

Deve ser fixada pelo prazo mínimo de seis meses e guarda grande similitude com a suspensão condicional da execução da pena privativa de liberdade, prevista nos artigos 77 a 82 do Código Penal, bem como com o período de prova da suspensão condicional do processo disposto no artigo 89, parágrafo $1^{\circ}$, da Lei 9.099/95.

\subsubsection{Semiliberdade}

Regulado pelo artigo 39 do Código de Menores e atualmente pelo artigo 120 do Estatuto da Criança e do Adolescente, o regime de semiliberdade é modalidade de medida privativa de liberdade na qual se possibilita, sem a necessidade de autorização do magistrado, a realização de atividades externas de caráter pedagógico, ligadas ao estudo e à profissionalização do adolescente, recolhendo-se ele no período noturno para pernoitar na instituição.

${ }^{673}$ GÓMEZ RIVERO, Maria Carmen. Algunos aspectos de la Ley Orgânica 5/2000, de 12 de enero, reguladora de la responsabilidad penal del menor. Actualidad Penal, Madri, n.10, p. 163-187, 2001. p. 179. Note-se que o termo menor é utilizado no presente excerto não com o sentido negativo historicamente atribuído à expressão, porque no direito espanhol a palavra é correntemente empregada, sem as conotações estigmatizantes que a ela foram atribuídas aqui.

${ }^{674}$ SARAIVA, João Batista Costa. Compêndio de Direito Penal Juvenil: adolescente e ato infracional. 3. ed. Porto Alegre: Livraria do advogado, 2006. p. 162. 
Por isso, é cumprida em estabelecimentos que geralmente não possuem grandes recursos de contenção.

Seu prazo é indeterminado, bem assim a conveniência de sua continuidade ou cessação depende de avaliação realizada pelo setor técnico.

Não tendo sido expressamente previsto seu período máximo de duração, aplicam-se a essa medida as disposições relativas a internação: o relatório de sua execução deve ser realizado e encaminhado ao juízo da execução no máximo a cada seis meses, podendo a privação de liberdade perdurar por no máximo três anos, com a liberação compulsória dos jovem aos vinte e um anos de idade.

A semiliberdade pode ser fixada como medida ordinária, ou seja, imposta inicialmente, ou ser substitutiva da internação anteriormente aplicada, como forma de transição para o meio aberto.

A despeito de também privar o jovem de seu direito de ir e vir livremente e submetê-lo a institucionalização, a semiliberdade ainda é melhor do que a internação, pois permite a mantença do contato entre o infrator, sua família e a sociedade, o combate à ociosidade por meio da realização de atividades fora da instituição e é menos onerosa para o Estado em cotejo com a medida cumprida em regime fechado.

Sua execução deve respeitar as diretrizes estabelecidas na Resolução $n^{\circ} 47$ do Conanda, de 5 de dezembro de 1996.

\footnotetext{
Artigo $1^{\circ}$. O regime de semiliberdade, como medida socioeducativa autônoma, deve ser executada de forma a ocupar o adolescente em atividades educativas, de profissionalização e lazer, durante o período diurno, sob rigoroso acompanhamento e controle de equipe multidisciplinar especializada, e encaminhado ao convívio familiar no período noturno, sempre que possível.
}

Artigo $2^{\circ}$. A convivência familiar e comunitária do adolescente sob o regime de semiliberdade deverá ser, igualmente, supervisionada pela mesma equipe multidisciplinar.

Parágrafo único. A equipe multidisciplinar especializada incumbida do atendimento ao adolescente, na execução da medida de que trata este artigo, deverá encaminhar, semestralmente, relatório circunstanciado e propositivo ao Juiz da Infância e Juventude competente.

Percebe-se que a medida guarda grande proximidade com a pena privativa de liberdade cumprida no regime aberto, cuja execução deve ocorrer em um instituto penal agrícola, industrial ou similar, ou em uma casa do albergado, nos termos do artigo 33 do Código Penal e dos artigos 91 e 93 da Lei de Execuções Penais. 


\subsubsection{Internação}

A medida de internação é a mais gravosa entre as previstas na legislação estatutária, pois pressupõe o cerceamento da liberdade de locomoção do adolescente em tempo integral. Nesses termos, e quanto à sua forma de cumprimento, assemelha-se à pena privativa de liberdade, em regime fechado, prevista no Código Penal.

A medida já era prevista nos artigos 40 e 41 do Código de Menores ${ }^{675}$ e atualmente é disciplinada nos artigos 121 e seguintes do Estatuto da Criança e do Adolescente.

Consoante o artigo 123 do Estatuto a internação deve ser cumprida em entidade exclusivamente destinada aos menores de idade comprovadamente autores de ato infracional, obedecendo-se rigorosa separação por critérios de idade, compleição física e gravidade da infração, sendo ainda obrigatório o oferecimento de atividades pedagógicas no local de cumprimento da internação.

A despeito de ser medida privativa de liberdade, nos termos do artigo 121, parágrafo $1^{\circ}$, do Estatuto, pode ser aplicada com a permissão de realização de atividades externas, circunstância que deve ser analisada pela equipe técnica, salvo determinação judicial em contrário.

Tem prazo máximo de três anos e exige a liberação compulsória do infrator que atingir os vinte e um anos de idade. No entanto, o tempo de internação de cada adolescente é determinado apenas no decorrer da execução da medida, já que sua soltura depende de

675 “Art. 40. A internação somente será determinada se for inviável ou malograr a aplicação das demais medidas.

Art. 41. O menor com desvio de conduta ou autor de infração penal poderá ser internado em estabelecimento adequado, até que a autoridade judiciária, em despacho fundamentado, determine o desligamento, podendo, conforme a natureza do caso, requisitar parecer técnico do serviço competente e ouvir o Ministério Público.

$\S 1^{\circ} \mathrm{O}$ menor sujeito à medida referida neste artigo será reexaminado periodicamente, com o intervalo máximo de dois anos, para verificação da necessidade de manutenção da medida.

$\S 2^{\circ} \mathrm{Na}$ falta de estabelecimento adequado, a internação do menor poderá ser feita, excepcionalmente, em seção de estabelecimento destinado a maiores, desde que isolada destes e com instalações apropriadas, de modo a garantir absoluta incomunicabilidade.

$\S 3^{\circ}$ Se o menor completar vinte e um anos sem que tenha sido declarada a cessação da medida, passará à jurisdição do Juízo incumbido das Execuções Penais.

$\S 4^{\circ} \mathrm{Na}$ hipótese do parágrafo anterior, o menor será removido para estabelecimento adequado, até que o Juízo incumbido das Execuções Penais julgue extinto o motivo em que se fundamentara a medida, na forma estabelecida na legislação penal" (grifos nossos). 
parecer de avaliação periódica realizada por uma equipe multidisciplinar de profissionais, funcionários da instituição, o qual será analisado e valorado pelo magistrado ${ }^{676}$.

Tendo em vista a indeterminação, de antemão, da duração total da privação da liberdade, a qual dependerá do comportamento do jovem durante sua reclusão, evidenciase aqui a incidência de uma reserva legal meramente parcial.

Assim sendo, de acordo com Machado,

concedeu-se bom espaço para as concepções autoritárias de Direito Penal, porque o adolescente é responsabilizado não por aquilo que ele já fez, mas também pelo comportamento que terá após a aplicação da medida sócioeducativa, mesmo que este comportamento não seja criminoso [...] Isso é injusto e discrepa de um sistema democrático de responsabilização de natureza penal ${ }^{677}$.

Ainda em virtude da mencionada indeterminação, Frasseto defende que a execução dessa medida realiza-se nos termos do prognóstico da reincidência, uma vez que é a visualização da futura reiteração delitiva que embasa a decisão da soltura ou mantença da custódia do jovem. Trata-se, pois, da lógica positivista da periculosidade, do objetivo preventivo especial operacionalizando todo o sistema de execução ${ }^{678}$.

Nesse sentido, ressalta o autor que "a própria verificação das necessidades pedagógicas do adolescente (art. 100/113 do ECA) como uma das diretrizes mestras de definição do regimento adequado prestigia o entendimento de que o foco é mais no autor do que no crime propriamente dito"

Note-se também que a estruturação da família do jovem e sua possibilidade de recebê-lo adequadamente quando da desinternação é considerada nesse momento, o que faz com que o encerramento da internação dependa de fatores alheios ao adolescene, sobre os quais ele sequer pode intervir.

\footnotetext{
${ }^{676} \mathrm{Na}$ visão de Frasseto, “o invariável recrutamento do psicológico para avaliar, reavaliar e intervir nos casos expressa a idéia de que o delito seja fundamentalmente a expressão de uma disfuncionalidade do aparelho psíquico, que deve ser tratada para que não enseje nova transgressão”. Cf. FRASSETO, Flávio Américo. Execução da medida sócio-educativa de internação: primeiras linhas de uma crítica garantista. In: ILANUD et al. (Org.). Justiça, adolescente e ato infracional: socioeducação e responsabilização. São Paulo: ILANUD, 2006. p. 315.

${ }^{677}$ MACHADO, Martha de Toledo. Sistema especial de proteção da liberdade do adolescente na Constituição brasileira de 1988 e no estado da criança e do adolescente. In: ILANUD et al. (Org.). Justiça, adolescente e ato infracional: socioeducação e responsabilização. São Paulo: ILANUD, 2006. p. 118.

${ }^{678}$ FRASSETO, Flávio Américo. Execução da medida sócio-educativa de internação: primeiras linhas de uma crítica garantista. In: ILANUD et al. (Org.). Justiça, adolescente e ato infracional: socioeducação e responsabilização. São Paulo: ILANUD, 2006.

${ }^{679}$ FRASSETO, Flávio Américo. Execução da medida sócio-educativa de internação: primeiras linhas de uma crítica garantista. In: ILANUD et al. (Org.). Justiça, adolescente e ato infracional: socioeducação e responsabilização. São Paulo: ILANUD, 2006. p. 329.
} 
Não obstante as colocações acima expostas há autores que não enxergam a indeterminação desde logo do prazo de internamento de modo negativo.

Para García Méndez a indeterminação aqui não se confunde com o caráter indeterminado das sentenças que existia no sistema tutelar, uma vez que este se constituía "em uma medida de proteção abstrata da sociedade e de desnecessária punição concreta do indivíduo. Agora, conforme o Estatuto, o caráter indeterminado funciona a favor da proteção (integral) da pessoa humana em desenvolvimento" ${ }^{\text {680 }}$.

Também para Shecaira "a inexistência de medida sócio-educativa por tempo certo [...] é uma exigência natural da condição peculiar de pessoa em desenvolvimento" ${ }^{681}$. Para ele, conforme já se aventou no presente trabalho, a indeterminação da internação é reflexo do princípio da proporcionalidade mitigada, pelo qual uma conduta infracional grave pode receber uma punição de no máximo três anos ${ }^{682}$.

De qualquer maneira, enquanto o inimputável - após ser apreendido - não ostentar comportamento que permita ao Órgão Técnico da instituição e ao Juízo da Infância concluírem que está apto a retomar o comportamento socialmente adequado, ficará internado; se, por outro lado, demonstrar que não mais apresenta desvio comportamental grave, será desinternado - com a consequente extinção ou progressão da medida.

Diversa a situação relativa às demais medidas, pois, em regra, sua duração subordina-se à gravidade e ao número de atos praticados.

Diante disso, para Frasseto, na internação

o trabalho de doutrinação, escondido sob o rótulo de educação, tem de ser bem sucedido, uma vez que condição precípua para libertação é a efetiva incorporação (introjeção) de valores morais condizentes com a vida aceitável em sociedade $^{683}$.

Importante salientar que, a despeito de ser dever do Estado oferecer um programa pedagógico ao jovem internado, a execução dessa medida "não pode impor regras e

\footnotetext{
${ }^{680}$ CURY, Munir; SILVA, Antônio Fernando Amaral e; GARCÍA MENDEZ, Emílio (Coord.). Estatuto da Criança e do Adolescente Comentado: Comentários jurídicos e sociais. 5. ed. São Paulo: Malheiros, 2002. p. 414.

${ }^{681}$ SHECAIRA, Sérgio Salomão. Sistema de Garantias e o Direito Penal Juvenil. São Paulo: Revista dos Tribunais, 2008. p. 207.

${ }^{682}$ SHECAIRA, Sérgio Salomão. Sistema de Garantias e o Direito Penal Juvenil. São Paulo: Revista dos Tribunais, 2008.

${ }^{683}$ FRASSETO, Flávio Américo. Execução da medida sócio-educativa de internação: primeiras linhas de uma crítica garantista. In: ILANUD et al. (Org.). Justiça, adolescente e ato infracional: socioeducação e responsabilização. São Paulo: ILANUD, 2006. p. 320.
} 
normas que visem ao ajustamento de sua conduta, pois o adolescente é sujeito ativo, na medida em que pensa, reflete, age e constrói as relações no ambiente da internação" ${ }^{\text {,684 }}$.

No que concerne ao citado interregno de três anos de internação, é ele constantemente suscitado como exíguo quando consubstanciada a prática de ato infracional de natureza grave ${ }^{685}$.

Não obstante essa posição, crê-se que três anos na vida de um jovem que dela pouco desfrutou é um interregno bastante considerável. Além disso, poucos são os casos de prática de ato infracional grave, a exigir um alargamento do prazo de privação de liberdade.

Aponta-se, nesse diapasão, a incongruência da legislação da Costa Rica, que, a despeito de adotar um sistema de justiça juvenil, fixa o prazo da privação de liberdade em $15 \operatorname{anos}^{686}$.

Também a legislação espanhola prevê, em casos de extrema gravidade, a aplicação de sanção por dez anos, a primeira metade do período cumprida em internação no regime fechado e a outra metade em liberdade vigiada. Em crítica a esse quadro Gómez Rivero defende que "se se carece de uma década para educar é pura e claramente porque a medida educativa carece de eficácia" ${ }^{\circ 87}$.

Nos termos dos artigos 112, parágrafo $1^{\circ}$, e 113 do Estatuto da Criança e do Adolescente devem ser consideradas para a escolha da medida socioeducativa adequada a gravidade, as circunstâncias do ato infracional e as necessidades pedagógicas do adolescente.

Nessa seara, em dissonância do que ocorre com as penas estipuladas aos adultos, na imposição concreta das medidas socioeducativas o magistrado deve dar prevalência às questões subjetivas sobre as objetivas. Ou seja, aqui, o ato ilícito praticado pelo adolescente é condição, pressuposto para o cabimento da intervenção estatal, mas não é

${ }^{684}$ MONDRAGÓN, Geraldo Bohórquez; CHINGAL, Elkin Paez. A medida socioeducativa de internação: uma construção de relações. In: ILANUD et al. (Org.). Justiça, adolescente e ato infracional: socioeducação e responsabilização. São Paulo: ILANUD, 2006. p. 576.

${ }^{685}$ Note-se que, na realidade, nos termos do Estatuto da Criança e do Adolescente, a privação da liberdade de um jovem pode perdurar por até seis anos, uma vez que, após cumprido o limite máximo de três anos de internação, o magistrado pode determinar que o adolescente submeta-se também a medida de semiliberdade, a qual tem o mesmo prazo máximo de duração, devendo o interno ser liberado, de qualquer das medidas, as completar vinte e um anos de idade.

${ }^{686}$ GARCÍA MÉNDEZ, Emilio. Evolución historica del derecho de la infancia: Por que uma historia de los derechos de la infância? In: ILANUD et al. (Org.). Justiça, adolescente e ato infracional: socioeducação e responsabilização. São Paulo: ILANUD, 2006. p. 7-23.

687 GÓMEZ RIVERO, Maria Carmen. Algunos aspectos de la Ley Orgânica 5/2000, de 12 de enero, reguladora de la responsabilidad penal del menor. Actualidad Penal, Madri, n.10, p. 163-187, 2001. p. 174. 
fator determinante para a escolha da medida, a qual se rege pelas circunstâncias pessoais do jovem.

A limitação objetiva, pois, no caso dos adolescentes, serve apenas para que a ele nunca seja concedido tratamento legal mais severo do que seria dispensado ao adulto autor de conduta análoga. Para Frasseto, "sustentar o contrário significa aproximar a resposta socioeducativa da resposta penal exatamente no ponto fundamental que as distingue"

Logo, desfrutam de certo de grau de liberdade os operadores do direito, podendo analisar a situação concreta e as condições pessoais do adolescente que praticou um ato infracional. Essa possibilidade de escolha sofre limitações apenas quando se tratar da medida de internação, cujas hipóteses de cabimento encontram-se expressas no Estatuto.

Assim, consoante o artigo 122 do Estatuto, a internação somente pode ser aplicada em algumas poucas hipóteses, excepcionais. Apenas quando se tratar de ato infracional cometido com violência ou grave ameaça à pessoa, por reiteração no cometimento de outras infrações graves e por descumprimento reiterado e injustificado da medida anteriormente imposta, a denominada internação-sanção ${ }^{689}$

Para Costa, a despeito de tentar limitar as possibilidades de privação de liberdade, a redação desse artigo representa um dos maiores problemas do Estatuto, justamente porque ela dá margem a interpretações subjetivadas. Para a autora, o termo "grave ameaça à pessoa" não vincula necessariamente ao capítulo do Código Penal que disciplina os crimes contra as pessoas. Ademais, defende que o requisito "reiteração de atos infracionais graves" permite diversas leituras dissonantes ${ }^{690}$.

Numa tentativa de estabelecer parâmetros quanto a essa última expressão - atos infracionais graves - propugna-se que deve ser ela compreendida como infração punida no Direito Penal dos adultos com pena de reclusão ${ }^{691}$.

\footnotetext{
${ }^{688}$ FRASSETO, Flávio Américo. Esboço de um roteiro para aplicação das medidas socioeducativas. Revista Brasileira de Ciências Criminais, São Paulo, a. 7, n. 26, p. 159-195, abr./jun. 1999. p. 182.

${ }^{689}$ Não apenas a internação, mas também a medida de semiliberdade sujeita-se a essa limitação, por importarem ambas em privação de liberdade, em maior ou menor grau. Na hipótese da internação-sanção, por sua vez, o adolescente deve ser ouvido para explicar-se acerca do descumprimento da medida anterior, sob pena de anulação da conversão realizada sem essa observância.

${ }^{690}$ COSTA, Ana Paula Motta. As garantias processuais e o Direito Penal Juvenil como limite na aplicação da medida socioeducativa de internação. Porto Alegre: Livraria do Advogado, 2005. Insta salientar que o Superior Tribunal de Justiça considera reiteração de ato infracional a prática de pelo menos três condutas ilícitas.

${ }^{691}$ FRASSETO, Flávio Américo. Esboço de um roteiro para aplicação das medidas socioeducativas. Revista Brasileira de Ciências Criminais, São Paulo, a. 7, n. 26, p. 159-195, abr./jun. 1999.
} 
Para Saraiva, de um ponto de vista garantista, melhor seria, nesses casos, que o legislador tivesse anunciado expressamente os tipos penais autorizadores da privação da liberdade ${ }^{692}$.

Tratando-se, pois, de um rol exaustivo o expresso no artigo 122 - ainda que ensejador de interpretações totalitárias -, não se pode admitir seja determinada a reclusão de um adolescente pela prática de ato infracional equiparado ao tráfico de drogas, ainda que seja essa conduta assemelhada à hedionda, por falta de previsão legal permissiva nesse sentido.

Sendo a traficância "ação não caracterizada pela violência ou grave ameaça somente pode determinar a internação quando da sua reiteração, nos termos exatos dos incisos I e II do artigo 122 do Estatuto da Criança e do Adolescente"693.

Entretanto, em evidente afronta à disposição estatutária, é cada vez maior o número de adolescentes, menores de 14 anos, internados pela prática de ato infracional equiparado ao crime de tráfico de drogas.

Em dados de 2008 da Fundação Casa 34\% dos adolescentes na faixa etária mencionada estão internados por conta do comércio ilícito dessas substâncias proibidas, enquanto em 2002 essa porcentagem não ultrapassava os $8 \%{ }^{694}$.

Lembre-se, porém, que, mesmo que nas hipóteses permissivas previstas, a internação só deve ser imposta quando se verificar ser a medida mais adequada no caso concreto.

Nesse diapasão, para Sotto Maior Netto, sendo mister a medida ser a mais adequada, a internação ou semiliberdade impostas com base na mera gravidade do ato devem ser consideradas eivadas pelo vício insanável da nulidade ${ }^{695}$.

Após verificada sua pertinência e determinada sua aplicação, deve-se ter em mente que a internação não se encerra com a mera contenção do jovem, mas com sua contenção

\footnotetext{
${ }^{692}$ SARAIVA, João Batista Costa. Compêndio de Direito Penal Juvenil: adolescente e ato infracional. 3. ed. Porto Alegre: Livraria do advogado, 2006.

${ }^{693}$ GARRIDO DE PAULA, Paulo Afonso. Ato infracional e natureza do sistema de responsabilização. In: ILANUD et al. (Org.). Justiça, adolescente e ato infracional: socioeducação e responsabilização. São Paulo: ILANUD, 2006. p. 44.

${ }^{694}$ ARANDA, Fernanda. Cresce apreensão de menores de 14. O Estado de São Paulo, São Paulo, 12 dez. 2008. Cidade, p. 1.

${ }^{695}$ SOTTO MAIOR NETO, Olympio de Sá. Garantias penais do adolescente autor de ato infracional. In: ILANUD et al. (Org.). Justiça, adolescente e ato infracional: socioeducação e responsabilização. São Paulo: ILANUD, 2006. p. 123-149.
} 
em um sistema de segurança eficaz. Nas palavras de Volpi, "a contenção não é em si a medida socioeducativa, é a condição para que ela seja aplicada"696.

Assim, "todos aqueles que são privados de liberdade - e, reafirme-se, devem ser poucos - só o serão como condição para o cumprimento da medida sócio-educativa. Isto é, a contenção é o meio para que o fim pedagógico seja cumprido"697.

Ademais, o que se retira do adolescente com a imposição da internação é sua liberdade de locomoção, mas não sua liberdade de opinião e de crença, sua individualidade ou sua integridade física, psicológica e moral ${ }^{698}$.

Não se deve e nem sequer se pode infligir ao jovem um mal ainda maior do que o representado pela sua reclusão ${ }^{699}$.

A internação, dado o rigor que o Estatuto exige - ao menos no plano teórico - à sua imposição e execução, sujeita-se aos princípios da excepcionalidade, brevidade e pela consideração do adolescente como pessoa em condição peculiar de desenvolvimento ${ }^{700}$.

O princípio da excepcionalidade apresenta-se no momento da escolha, pelo Juiz da Vara da Infância e Juventude, da medida socioeducativa que deve ser imposta ao adolescente. A internação só deve ter lugar quando nenhuma outra medida atender às suas necessidades; deve então ser aplicada apenas excepcionalmente. Apresenta-se como limite lógico no processo decisório da escolha da medida.

É em virtude dessa regra que Beloff defende que é incorreto nesse sistema falar, tal qual se faz no de adultos, em alternativas à privação de liberdade, por não ser ela medida central do modelo juvenil. Aqui, a centralidade é de todas as outras sanções ${ }^{701}$. Aqui, alternativo e excepcional é a privação de liberdade.

\footnotetext{
${ }^{696}$ VOLP, Mário (Org.). O adolescente e o ato infracional. 3. ed. São Paulo: Cortez, 1999. p. 29.

${ }^{697}$ SHECAIRA, Sérgio Salomão. Sistema de Garantias e o Direito Penal Juvenil. São Paulo: Revista dos Tribunais, 2008. p. 205.

${ }^{698}$ COSTA, Antônio Carlos Gomes da. Natureza e essência da ação socioeducativa. In: ILANUD et al. (Org.). Justiça, adolescente e ato infracional: socioeducação e responsabilização. São Paulo: ILANUD, 2006.

${ }^{699}$ O artigo 124 do Estatuto da Criança e do Adolescente disciplina em seu artigo 124 os direitos do adolescente privado de liberdade, dentre os quais se prevê seu direito de ser tratado com respeito e dignidade, de receber visitas ao menos semanalmente, de corresponder-se com sua família e amigos, de ter acesso aos objetos necessários a sua higiene e asseio pessoal, dentre outros.

${ }^{700}$ Lembre-se mais uma vez que não apenas a internação, mas também a medida de semiliberdade sujeita-se aos mencionados princípios, por importarem ambas em privação de liberdade, em maior ou menor grau.

${ }^{701}$ BELOFF, Mary. Algunas confusiones en torno a las consecuencias jurídicas de la conducta trangresora de la ley penal en los nuevos sistemas de justicia juvenil latinoamericanos. In: GARCÍA MENDÉZ, Emilio (Comp.). Adolescentes y Responsabilidad Penal. Buenos Aires: Ad-Hoc, 2001. p. 29-69.
} 
Para Frasseto o legislador pátrio, ao disciplinar a excepcionalidade da internação, partiu da ideia - correta - de que a institucionalização é instrumento totalmente fracassado de controle dos jovens autores de atos infracionais ${ }^{702}$.

Fato é que

a opção pela privação de liberdade resulta muito mais da inexistência de outra alternativa do que da indicação de ser esta a melhor dentre as alternativas disponíveis. Somente se justifica enquanto mecanismo de defesa social, pois não há nada mais falacioso do que o imaginário de que a privação de liberdade poderá representar em si mesma um bem para o adolescente a que se atribui a prática de uma ação delituosa ${ }^{703}$.

A brevidade, limite cronológico da imposição da internação, tem lugar quando da execução da citada medida. Por ela, a reprimenda deve durar o menor espaço temporal possível, razão pela qual está sujeita a avaliações periódicas por uma equipe multidisciplinar, no máximo a cada seis meses, visando a verificar se a medida corresponde às necessidades do adolescente que está em constante transformação.

O princípio da condição peculiar de pessoa em desenvolvimento, conforme consignado no item 3.2.1, considera as especificidades da etapa de crescimento em que se encontra o jovem, o que importa em que ele tenha uma disciplina diversa da dos adultos. É, pois, o limite ontológico que deve ser observado na decisão e na implementação da citada reprimenda juvenil.

A despeito de todas as medidas enunciadas ao menos deverem - pela exegese do Estatuto da Criança do Adolescente e da exigência da Proteção Integral que dele emana contemplar uma proposta pedagógica consistente e realizável isso parece bastante utópico quando se trata da internação.

Isso porque

o convívio num mesmo ambiente de uma população de idades e trajetórias muito distintas, com diferentes níveis de agressividade e tendo em comum apenas o gosto pelo ilícito, eleva sensivelmente o risco de fracasso da proposta 'reeducativa', favorecendo amplamente a disseminação de hábitos e costumes aplicados unicamente na construção de novas formas de burlar as normas ${ }^{704}$.

\footnotetext{
${ }^{702}$ FRASSETO, Flávio Américo. Esboço de um roteiro para aplicação das medidas socioeducativas. Revista Brasileira de Ciências Criminais, São Paulo, a. 7, n. 26, p. 159-195, abr./jun. 1999.

${ }^{703}$ SARAIVA, João Batista Costa. Compêndio de Direito Penal Juvenil: adolescente e ato infracional. 3. ed. Porto Alegre: Livraria do advogado, 2006. p. 172.

${ }^{704}$ MONDRAGÓN, Geraldo Bohórquez; CHINGAL, Elkin Paez. A medida socioeducativa de internação: uma construção de relações. In: ILANUD et al. (Org.). Justiça, adolescente e ato infracional: socioeducação e responsabilização. São Paulo: ILANUD, 2006. p. 573.
} 
Nesse sentido, aqui, "o que deveria ser estabelecido como meta é a nãodessocialização, que, então, ocuparia o lugar da desgastada ideia de ressocialização" ${ }^{\text {705 }}$.

Assim, a questão que remanesce após a análise da medida de internação é "qual é a educação possível em condições nas quais não existe o valor da dignidade?"706.

705 SICA, Ana Paula Zomer. Prevenção Criminal: análise de políticas extrapenais. Rio de Janeiro: Lumen Juris, 2009.

${ }^{706}$ TEIXEIRA, Maria de Lourdes Trassi. Evitar o desperdício de vidas. In: ILANUD et al. (Org.). Justiça, adolescente e ato infracional: socioeducação e responsabilização. São Paulo: ILANUD, 2006. p. 442. 


\section{CAPÍTULO 4. INSTITUCIONALIZAÇÃO E PRISIONIZAÇÃO}

A importância do estudo dos fenômenos da institucionalização e da prisionização consiste no fato de que aquele permite a compreensão de como se formam as diversas facetas da identidade da criança e do adolescente submetidos a um longo período de internação, enquanto este ajuda no entendimento de como ocorre a metamorfose dessas identidades em uma identidade criminosa ${ }^{707}$.

Já se enunciou no presente trabalho a desigualdade da seleção realizada pelo sistema penal e as consequências negativas que podem advir do contato do sujeito com ele, salientando-se que quanto maior for esse contato, ou seja, quanto mais o indivíduo adentrar nas esferas de controle penal, mais consequências negativas e estigmatização se produzirão.

Por conseguinte, "a parte mais importante da deterioração condicionante fica por conta da 'instituição total",708.

Vislumbrando-se as características das instituições totais propostas por Goffman, tem-se que os estabelecimentos de privação de liberdade destinados aos autores de atos infracionais podem ser facilmente enquadrados nessa definição.

Nas instituições totais as atividades de dormir, brincar e trabalhar são desempenhadas num mesmo local e sob uma única autoridade; estas realizam-se na companhia imediata de um grupo de pessoas, todas tratadas da mesma maneira e obrigadas a cumprir as mesmas tarefas; há horários a serem observados na consecução dessas atividades e o controle das necessidades dos ali recolhidos é realizado pela organização burocrática de um grupo de pessoas, os funcionários da instituição ${ }^{709}$.

Outrossim, elas exercitam sucessivos processos de mortificação do eu como, por exemplo, a separação entre o mundo externo e interno que impõe, a qual provoca o despojamento do papel que o sujeito ostentava do lado de fora; o processo de admissão na instituição - a entrega dos objetos pessoais, o recebimento do uniforme, o corte do cabelo,

\footnotetext{
${ }^{707}$ SILVA, Roberto da. O que é institucionalização/prisionalização. Discursos Sediciosos: crime, direito e sociedade, Rio de Janeiro, a. 4, n. 7-8, p. 125-134, 1999.

${ }^{708}$ ZAFFARONI, Eugenio Raúl. Em busca das penas perdidas: a perda de legitimidade do sistema penal. Tradução de Vânia Romano Pedrosa e Amir Lopes da Conceição. 5. ed. Rio de Janeiro: Revan, 2001. p. 135. 709 GOFFMAN, Erving. Manicômios, prisões e conventos. Tradução de Dante Moreira Leite. 8. ed. São Paulo: Perspectiva, 2008.
} 
o banho, a instrução quanto as regras do local, o recebimento de um número de registro que pode substituir o uso do nome - constitui uma segunda mortificação do eu, ao enquadrar o interno no padrão exigido pela administração e despi-lo de seu conjunto de identidade; também a perda de um sentido de segurança pessoal, desenvolvendo-se um constante sentimento e sensação de ameaça a sua integridade física ${ }^{710}$.

Tudo isso se verifica também nas instituições juvenis, minando a plenitude da autonomia dos internos e permitindo sua qualificação como instituição total.

Em virtude da nova rotina imposta e de todos os ultrajes que aí se verificam, pode advir da passagem pela internação o fenômeno da institucionalização, ao qual subjaz "o processo de confinamento de crianças e de adolescentes em estabelecimentos públicos ou privados, com características de instituição total"711. Representa ele a supressão da intimidade, da individualidade e das características individuais do jovem, introduzindo-o em um meio em que ele nunca será sujeito e onde todas as dimensões de sua vida passarão a ser encaradas sob o enfoque do que é mais conveniente para a instituição, em termos da observância de suas regras funcionais e disciplinares ${ }^{712}$.

Assim, a institucionalização, efeito do internamento juvenil, contempla

a dinâmica previamente criada por meio de inúmeros olhares, reduzindo as
crianças e adolescentes a objetos de análise de diversas práticas discursivas,
abrangendo as esferas jurídica, pedagógica e médica, além dos meios de
comunicação. Por meio da confluência destas vozes, procura-se a coisificação e
o enquadramento das crianças em espaços que se definem como
reeducacionais ${ }^{713}$.

Logo, ainda que se discutam as finalidades a que se propõem as medidas socioeducativas, não se podem negar os efeitos deletérios de sua vivência, mormente quando se trata da privação da liberdade.

Sobretudo o fator criminógeno ínsito a qualquer medida de caráter penal incide com mais força sobre a pessoa que ainda está formando sua personalidade ${ }^{714}$.

\footnotetext{
${ }^{710}$ GOFFMAN, Erving. Manicômios, prisões e conventos. Tradução de Dante Moreira Leite. 8. ed. São Paulo: Perspectiva, 2008.

${ }^{711}$ SILVA, Roberto da. O que é institucionalização/prisionalização. Discursos Sediciosos: crime, direito e sociedade, Rio de Janeiro, a. 4, n. 7-8, p. 125-134, 1999. p. 125.

${ }^{712}$ SILVA, Roberto da. O que é institucionalização/prisionalização. Discursos Sediciosos: crime, direito e sociedade, Rio de Janeiro, a. 4, n. 7-8, p. 125-134, 1999.

${ }^{713}$ RODRIGUES, Gutemberg Alexandrino. Os filhos do mundo: a face oculta da menoridade (1964-1979). São Paulo: IBCCRIM, 2001. p. 28.

${ }^{714}$ MACHADO, Martha de Toledo. Sistema especial de proteção da liberdade do adolescente na Constituição brasileira de 1988 e no estado da criança e do adolescente. In: ILANUD et al. (Org.). Justiça, adolescente e ato infracional: socioeducação e responsabilização. São Paulo: ILANUD, 2006.
} 
Explica-se. Em torno dos dez ou doze anos de idade, a criança já adquiriu vários elementos de sua autoimagem, uma vez que ela já construiu uma autoimagem física, introjetou as reações do outro, fez comparações com companheiros e irmãos e formou identificações com pais e outros referenciais de comportamento. Nesse momento, porém, esses elementos ainda podem ser bastante inconsistentes e carentes de uma unidade particular, tais como o gosto por trigonometria e ursinhos, soldados e escola dominical, e assim por diante. Entretanto, a criança ainda não tem nenhum compromisso muito firme com qualquer desses elementos e não existem intenções de que eles se tornem objetivos a longo prazo ou um estilo de vida permanente, sendo esses papéis, em grande parte, meros jogos que devem ser jogados. Não obstante, com o início da adolescência, tudo isso é mudado e durante os poucos anos seguintes há uma crescente pressão para que ele desenvolva uma identidade unificada, que representa valores básicos e compromissos permanentes $^{715}$.

Portanto, o contato nessa fase com o sistema de justiça juvenil, exatamente no auge da adolescência, é que determinará sobremaneira a identidade assumida pelo jovem. Sua personalidade e suas vivências serão efetivadas num ambiente inatural e contracultural, não condizente com a vida em liberdade. Internado o adolescente, não obstante um ser único em desenvolvimento, de vontade própria, perde sua autonomia, sua capacidade de autodeterminação e passa a assumir, fatalmente, a condição de passividade, assegurando, assim, sua própria sobrevivência em meio fechado ${ }^{716}$.

Por serem inconciliáveis com o desfrute da liberdade, ainda que as instituições reunissem condições ideais para o tratamento do jovem, elas seriam danosas e contraproducentes $^{717}$. A internação, assim, “constitui-se na medida sócio-educativa com as piores condições para produzir resultados positivos" ${ }^{, 718}$.

\footnotetext{
715 ARGYLE, Michael. A interação social: relações interpessoais e comportamento social. Tradução de Márcia Bandeira de Mello Leite Nunes. Rio de Janeiro: Zahar, 1976. p. 437.

716 JUNQUEIRA, Ivan de Carvalho. Do ato infracional à luz dos Direitos Humanos. Campinas: Russell, 2009. p. 100.

${ }^{717}$ FRASSETO, Flávio Américo. Esboço de um roteiro para aplicação das medidas socioeducativas. Revista Brasileira de Ciências Criminais, São Paulo, a. 7, n. 26, p. 159-195, abr./jun. 1999. p. 184.

${ }^{718}$ SOTTO MAIOR NETO, Olympio de Sá. Garantias penais do adolescente autor de ato infracional. In: ILANUD et al. (Org.). Justiça, adolescente e ato infracional: socioeducação e responsabilização. São Paulo: ILANUD, 2006. p. 135.
} 
Contudo, além das mencionadas problemáticas inerentes à privação da liberdade, na realidade de sua execução revelam-se traços "absolutamente incompatíveis com o status de cidadão outorgado aos adolescentes pela normativa em vigor" ${ }^{, 719}$.

Bretan, em sua dissertação de mestrado, analisou as produções acadêmicas da USP e da PUC-SP envolvendo o tema adolescente e o ato infracional. Apesar de constatar serem poucos os estudos sobre a temática, relata que houve um incremento deles no período de 1999 a 2001, sendo ainda que entre 2002 e 2006 foram produzidos 63\% dos trabalhos por ela pesquisados.

A autora relaciona esse aumento à maior visibilidade e ocorrência de rebeliões nas unidades de internamento de jovens de São Paulo, bem como à divulgação de estudos internacionais dando conta das condições desumanas a que estavam submetidos os internos $^{720}$.

O Relatório Global sobre a situação dos Direitos Humanos no mundo 2000 constatou que as condições de reclusão dos adolescentes no Brasil, no ano de 1999, ficaram muito aquém das exigidas pelas normativas internacionais e pelo Estatuto da Criança e do Adolescente. De acordo com o estudo, uma série de rebeliões nos estabelecimentos de detenção para adolescentes localizados no Estado de São Paulo demonstrou a inabilidade em se manter a segurança ou garantir normas mínimas de acomodação decente para os jovens mantidos nesses locais.

Verificou-se a ocorrência de rebeliões nos meses de maio e julho na unidade Tatuapé da FEBEM; em agosto e setembro de grandes fugas na unidade Imigrantes, a qual abrigava 1300 jovens, quando sua capacidade era de 400. Também nesta unidade equipes de televisão flagraram jovens sendo agredidos com cassetetes por funcionários do complexo, mesmo após já terem sido reunidos, rendidos e despidos no pátio.

No Rio de Janeiro, internos do Instituto Padre Severino e da Escola João Luis Alves denunciaram casos de abusos sexuais envolvendo membros da supervisão desde, pelo menos, $1996^{721}$.

\footnotetext{
${ }^{719}$ FRASSETO, Flávio Américo. Execução da medida sócio-educativa de internação: primeiras linhas de uma crítica garantista. In: ILANUD et al. (Org.). Justiça, adolescente e ato infracional: socioeducação e responsabilização. São Paulo: ILANUD, 2006. p. 315.

${ }^{720}$ BRETAN, Maria Emília Accioli Nobre. Os múltiplos olhares sobre o adolescente e o ato infracional: análises e reflexões sobre teses e dissertações da USP e da PUCISP (1990 - 2006). 2008. 223f. Dissertação (Mestrado em Criminologia) - Faculdade de Direito, Universidade de São Paulo, [2008].

721 HUMAN WIGHTS WATCH. Siter Disponível <http://www.hrw.orgIspanish/inf_anual/2000Iamericas/brasil.html>. Acesso em: 1 de dez. 2009.
} 
No que se refere ao Estado de São Paulo, em virtude das constantes denúncias de violações de direitos humanos, no ano de 2006 a FEBEM mudou seu nome para Fundação CASA (Fundação Centro de Atendimento Socioeducativo ao Adolescente) e substituiu suas grandes unidades por outras menores, com capacidade máxima para cinquenta e seis jovens, visando a adequar a instituição às imposições do Estatuto da Criança e do Adolescente e do Sistema Nacional de Atendimento Socioeducativo (SINASE). Não obstante as citadas modificações, ainda são constantes os casos de tortura, agressão e maus tratos aos internos ${ }^{722}$.

Assim,

a relação cotidiana numa casa de reeducação e de contenção é, portanto, mais uma ocasião de transgressão e essa é a ordem das coisas...

Daí se pode pensar que, por todos os poros, naquela situação, respira-se violência, transgressão e infração. E que, se a FEBEM não cria a violência, ela parece ser um nicho privilegiado para sua reprodução ${ }^{723}$.

Em decorrência dos prejuízos advindos dessa experiência,

voltando o jovem às ruas e ao contexto de criminalidade, a tendência é de atos infracionais de maior gravidade e marcados por mais violência, mormente quando a experiência imediatamente anterior - privação de liberdade - é caracterizada pelo sofrimento, aflição e desprezo pelos valores da dignidade humana $^{724}$.

A internação, bem como todo o processo que antecede sua determinação, tem consequências nem sequer sonhadas para o jovem submetido a esta experiência.

A despeito de certamente haver muitos jovens igualmente culpados por um ato, somente alguns deles caem nas redes da justiça. Somente este que foi detectado pelo sistema recebe tratamento diverso dos demais, os quais, na realidade, são igualmente culpados. Assim, ele descobre um mundo totalmente novo, que pouco conhecia. Seu recolhimento precipita um sem-número de instituições, atitudes e experiências das quais as outras crianças não compartilham, tais como o contato com a Polícia, a apresentação perante uma Corte de Justiça e a internação. Por conta da prática de um ato comum para ele e sua gangue, este menino selecionado torna-se, de repente, o centro de um grande drama, no qual todo tipo de inesperados personagens assumem importantes papéis. Ele

722 Sobre o assunto ver: NÚCLEO DE ESTUDOS DA VIOLÊNCIA. Disponível em: $<$ http://www.nevusp.org/portugues/index.php?option=com_content\&task=view\&id=1792\&Itemid=155>. Acesso em: 1 de dez. 2009.

${ }^{723}$ GUIRADO, Marlene. Em instituições para adolescentes em conflito com a lei, o que pode a nossa vã psicologia? In: GONÇALVES, Hebe Signorini; BRANDÃO, Eduardo Ponte (Org.). Psicologia Jurídica no Brasil. 2. ed. Rio de Janeiro: Nau, 2005. p. 256.

${ }^{724}$ GARRIDO DE PAULA, Paulo Afonso. Ato infracional e natureza do sistema de responsabilização. In: ILANUD et al. (Org.). Justiça, adolescente e ato infracional: socioeducação e responsabilização. São Paulo: ILANUD, 2006. p. 42. 
passa a ser classificado como um ladrão e, talvez, o mundo torne-se um local diferente para ele e continuará assim pelo resto de sua vida ${ }^{725}$.

A situação narrada em relação às instituições para privação de liberdade dos jovens em conflito com a lei, todavia, não difere substancialmente da verificada nas prisões dos $\operatorname{adultos}^{726}$.

A denúncia dos males ocasionados pela reclusão e a dificuldade de readaptação do ex-detento à sociedade já era aventada antes mesmo do surgimento do labelling approach. É isso que se deflui da crítica formulada por Sutherland:

quando volta à sociedade o prêso é suspeitado, escarnecido, chamado de 'exdetento'. A dificuldade de conseguir emprêgo, o perigo de casar-se e ter filhos, a dificuldade de realizar qualquer coisa, são bem conhecidos. Se o prêso volta à sua própria comunidade, onde o seu caso é conhecido, consegue um status desejado apenas entre os criminosos e uns tantos filantropos. É habitual, nessas condições, em grande número de criminosos, o sentimento de uma dificuldade insuperável e da inutilidade do esforço. Consequientemente, muitos deles procuram consideração pela única maneira que encontram: pelo desenvolvimento de uma técnica criminosa eficiente e de uma atitude de ódio para com a sociedade; com isso logram a aprovação de certo grupo, no qual se asseguram um 'status' desejável ${ }^{727}$.

Também na perspectiva da teoria, a experiência da privação de liberdade deixa marcas indeléveis no sujeito que a vivencia, entre as quais se identificam a concentração e exasperação do seu conflito com a autoridade, a transformação da carreira criminal em algo mais natural e inevitável, ao estimular o que todos os reclusos têm em comum - o crime - e o agravamento e a intensificação do conflito entre ele e a sociedade.

Ela estigmatiza, consolida a delinquência, propulsiona a escalada de processos de socialização negativa e conduz à autodesintegração do indivíduo.

A privação da liberdade atende, pois, aos interesses de seus aplicadores e da sociedade e a nenhum interesse e proveito dos que a suportam. Apesar disso, mesmo que

\footnotetext{
${ }^{725}$ TANNEMBAUM, Frank. Crime and the community. Nova Iorque: Columbia University Press, 1951.

${ }^{726} \mathrm{O}$ surgimento da prisão não teve um caráter democrático. Ele foi consubstanciado por minorias progressistas, compostas basicamente por grupos culturais e políticos minoritários, especializados, que anteviam nessa forma de punição uma melhoria do sistema penal.

Hoje, no entanto, essa realidade é bastante diversa. Minorias progressistas se insurgem contra seu insucesso, enquanto que as maiorias populares, influenciadas pela mídia e por afãs políticos, de forma simplista e sem qualquer justificação técnica defendem sua existência e propugnam por seu incremento. Por mais que a prática já tenha demonstrado o fracasso das instituições coercitivas para a reabilitação dos criminosos, esta continua a ser a solução veementemente exclamada. Cf. PAVARINI, Massimo. Processos de recarcerização e 'novas' teorias justificativas da pena. In: ZOMER, Ana Paula (Org.). Ensaios Criminológicos. São Paulo: IBCCRIM, 2002.

${ }^{727}$ SUTHERLAND, Edwin H. Princípios de Criminologia. Tradução de Asdrúbal Mendes Gonçalves. São Paulo: Livraria Martins, 1949. p. 506-507.
} 
esse elemento não seja a priori percebido, ela é maléfica também para a sociedade, servindo como meio para que ela se aliene de seus conflitos e deixe de conhecê-los ${ }^{728}$.

Para Lemert o termo prisionização bem identifica o que acontece com um indivíduo recolhido ao cárcere. Trata-se de sua gradual aculturação e crescente participação nas organizações criminosas ao seu redor ${ }^{729}$. É “o processo de incorporação, por parte do preso adulto, da cultura e dos valores prisionais" ${ }^{, 730}$.

Lemert acredita que todos os reclusos são afetados por esse processo, mas cada qual de modo diverso. Os criminosos individuais e situacionais estão menos preparados e sentem mais fortemente sua mudança de status e os conflitos pela não aceitação intra e extra muros prisionais. Em contrapartida, os infratores profissionais conseguem lidar mais facilmente com essas questões.

Todos os reclusos, portanto, em maior ou menor grau, tornam-se prisionizados, sendo que o ápice do processo ocorre quando o interno adota o modo de vida e os códigos morais difundidos no ambiente prisional $^{731}$.

No mesmo sentido assevera Sá que a prisionização é praticamente inevitável, uma vez que é fenômeno inerente a vida carcerária. Ela assenta suas bases exatamente no processo de segregação social que subjaz o isolamento. Por isso, defende que a única forma de minorar seus efeitos é por meio da participação efetiva da sociedade na execução desta pena ${ }^{732}$.

Zaffaroni resume como ocorre a prisionização, efeito da prisão: primeiro o sujeito é levado a condições de vida nada condizentes com a vida em liberdade, uma vez que é privado de tudo que se faz ou que se deve fazer em meio aberto; depois sua autoestima é ferida de todas as maneiras possíveis; por fim, juntam-se a isso todas as condições deficientes desses estabelecimentos, tais como a superpopulação, a falta de higiene e de condições sanitárias, entre outras ${ }^{733}$.

\footnotetext{
${ }^{728}$ SÁ, Alvino Augusto de. Algumas ponderações acerca da reintegração social dos condenados à pena privativa de liberdade. Disponível em <www.eap.sp.gov. br/ponderacoes.pdf>. Acesso em 25 mai. 2007.

${ }^{729}$ LEMERT, Edwin M. Social Pathology: a systematic approach to the theory of sociopathic behavior. 1. ed. Nova Iorque: Toronto: Londres: McGraw-Hill, 1951.

${ }^{730}$ SILVA, Roberto da. O que é institucionalização/prisionalização. Discursos Sediciosos: crime, direito e sociedade, Rio de Janeiro, a. 4, n. 7-8, p. 125-134, 1999. p. 125.

${ }^{731}$ LEMERT, Edwin M. Social Pathology: a systematic approach to the theory of sociopathic behavior. 1. ed. Nova Iorque: Toronto: Londres: McGraw-Hill, 1951.

${ }^{732}$ SÁ, Alvino Augusto de. Prisionização: Um dilema para o cárcere e um desafio para a comunidade. Revista Brasileira de Ciências Criminais, São Paulo, a. 6, n. 21, p. 117-123, jan./mar. 1998.

${ }^{733}$ ZAFFARONI, Eugenio Raúl. Em busca das penas perdidas: a perda de legitimidade do sistema penal. Tradução de Vânia Romano Pedrosa e Amir Lopes da Conceição. 5. ed. Rio de Janeiro: Revan, 2001.
} 
Em vista dessa situação verificada no cárcere e dada a existência e reiteração em seu bojo de inúmeros problemas, entre os quais se podem citar a violência contra e entre os detentos, o desrespeito aos direitos humanos dos presos, a falta de estrutura física adequada à sobrevivência, entre outros, Sá relata ser bastante comum falar-se na existência de um "caos penitenciário"734.

Relata o autor poder advir o caos da inorganização, ou seja, pelo fato de algo não ter sido ainda organizado, ou da desorganização, produto de uma organização inadequada. Entretanto, menciona que a prisão não surgiu ao acaso, tendo sido sua organização elaborada antes de seu aparecimento. Também relata não se ter notícia de uma crise responsável pela perda de sentido do cárcere.

Defende, portanto, que ele, nos moldes em que está estruturado e com tudo aquilo que se pensam serem seus problemas, cumpre perfeitamente as funções a que se propõe. Em seus dizeres:

tudo o que acontece na história fatídica do cárcere, todos os alegados problemas não são expressão de caos algum, mas expressão do próprio cárcere, daquilo que ele é e pretende ser. As tais omissões dos poderes públicos não são omissões por esquecimento, ou devidas a uma lógica de priorização de verbas, mas são omissões programáticas. Ou melhor, não são omissões, são formas de ação, de gestão que se reproduzem unicamente por um motivo: por se tratar de cárcere e para reafirmar o seu sentido ${ }^{735}$.

Diante do exposto até aqui, evidencia-se que a experiência da privação de liberdade numa instituição total tem o poder de estremecer as bases sobre as quais o indivíduo sedimenta sua personalidade e redirecionar o rumo de sua história de vida. Institucionalização e prisionização, assim, não são fenômenos distintos; são faces da mesma moeda, um processo em contínuo cujo ápice é atingido quando as mutações que atingem o sujeito são tais que transformam alguém que não tinha a intenção de sistematicamente violar a lei em um criminoso.

\footnotetext{
${ }^{734}$ SÁ, Alvino Augusto de. O caos penitenciário... seria mesmo um caos? Boletim do Instituto Brasileiro de Ciências Criminais, São Paulo, a. 17, n. 203, p. 15-16, out. 2009.

${ }^{735}$ SÁ, Alvino Augusto de. O caos penitenciário... seria mesmo um caos? Boletim do Instituto Brasileiro de Ciências Criminais, São Paulo, a. 17, n. 203, p. 15-16, out. 2009. p. 16.
} 


\subsection{EFEITOS INSTITUCIONALIZANTES DA INTERNAÇÃO: O INÍCIO DAS CARREIRAS CRIMINAIS}

O indivíduo livre tem concepções seguras acerca de si mesmo, que foram construídas ao longo de sua interação com a sociedade. Ao adentrar numa instituição, em contrapartida, seu eu é sistematicamente mortificado devido às humilhações e degradações que sofre, o que gera progressivas mudanças em sua carreira moral, definida esta como as crenças que o sujeito tem a seu respeito e sobre os demais que são significativos para $\mathrm{ele}^{736}$.

Natural, então, que a partir dessa experiência ele construa novos referenciais de conduta.

Consoante o já explanado no presente trabalho, o criminoso, na visão emanada da teoria do labelling approach, é aquele que recebeu, por sua conduta, uma qualificação negativa do corpo social. É assim que ele é visto pela sociedade: um transgressor e nada mais.

Entretanto, ainda sob a ótica interacionista, só se torna efetivamente um delinquente o sujeito que, após seu contato com o sistema penal, assumindo para si a identidade que lhe foi atribuída pelos outros - sejam eles os internos ou os membros da sociedade livre -, desenvolve uma carreira criminal.

Nesse sentido, relata Tannenbaum que o criminoso difere dos demais indivíduos não criminosos no fato de ele ter aprendido a responder aos estímulos negativos do grupo, sendo que na inexistência deste ele poderia não existir ${ }^{737}$.

Fato é que

uma pessoa começa a ser tratada 'como se fosse', embora não haja manifestado nenhum comportamento que implique uma infração. Ao generalizar-se o tratamento de acordo com o 'como se fosse' e sustentar-se no tempo quase sem exceção, a pessoa passa a se comportar de acordo com o papel atribuído, ou seja, "como se fosse', e com isso acaba 'sendo, 738 .

Quando o condenado assume uma nova imagem de si e redefine sua personalidade nos termos da etiqueta desviada que lhe foi atribuída, efetiva-se a desviação secundária.

${ }^{736}$ GOFFMAN, Erving. Manicômios, prisões e conventos. Tradução de Dante Moreira Leite. 8. ed. São Paulo: Perspectiva, 2008.

${ }^{737}$ TANNEMBAUM, Frank. Crime and the community. Nova Iorque: Columbia University Press, 1951.

${ }^{738}$ ZAFFARONI, Eugenio Raúl. Em busca das penas perdidas: a perda de legitimidade do sistema penal. Tradução de Vânia Romano Pedrosa e Amir Lopes da Conceição. 5. ed. Rio de Janeiro: Revan, 2001. p. 134. 
Seus novos ilícitos serão, a partir de agora, produtos da redução de oportunidades e das transformações em sua subjetividade decorrentes da estigmatização.

Concretizadas todas essas mutações, pode o jovem mergulhar no papel criminal, fazendo a opção escancelada de enveredar pelo caminho das práticas ilícitas. Na terminologia adotada pela teoria trata-se do role-engulfment, giro qualitativo em que o indivíduo, depois de ter aceitado e se identificado com o papel que lhe foi imposto, passa a agir em conformidade com ele, organizando sua vida em torno da desviação e instituindo, assim, sua carreira criminal.

É esse o momento final de um processo com frequência desencadeado por algum contato com os agentes ou instituições do controle social formal ${ }^{739}$. O cárcere, aqui, representa

a ponta do iceberg que é o sistema penal burguês, o momento culminante de um processo de seleção que começa ainda antes da intervenção do sistema penal, com a discriminação social e escolar, com a intervenção dos institutos de controle do desvio de menores, da assistência social, etc. O cárcere representa, geralmente, a consolidação definitiva de uma carreira criminosa ${ }^{740}$.

Nos termos da explanação de Silva ${ }^{741}$, essencial num contexto de privação de liberdade a relação estabelecida pelo interno não apenas com a instituição, mas também com o grupo internado, ou seja, a relação interpares no ambiente institucional.

Tudo começa com a atribuição de um apelido, que representará, em grande medida, a imagem que o jovem sustenta perante os demais internos e funcionários. O domínio territorial exercido dentro do espaço institucional determina uma posição ou não de liderança sobre o grupo e é fator de aglutinação dos demais em torno desse interno. Também o uso da força, ou a disposição para usá-la na defesa de sua integridade sexual, é outro importante fator de aglutinação de indivíduos e de interesses.

É dentro desse processo de assunção de papéis que se estabelecerá a representação social do jovem perante os demais internos. Em outros termos, é assim que se cristalizará sua identidade institucional.

Ainda de acordo com o autor, essa identidade institucional propositadamente construída pelo jovem, visando a ser respeitado e assegurar sua boa sobrevivência na

\footnotetext{
${ }^{739}$ GARCÍA-PABLOS DE MOLINA, Antonio. Tratado de Criminología. 2. ed. Valência: Tirant lo blanch, 1999.

${ }^{740}$ BARATTA, Alessandro. Criminologia crítica e crítica do direito penal: introdução à sociologia do direito penal. Tradução de Juarez Cirino dos Santos. 2. ed. Rio de Janeiro: Freitas Bastos, 1999. p. 167.

${ }^{741}$ SILVA, Roberto da. O que é institucionalização/prisionalização. Discursos Sediciosos: crime, direito e sociedade, Rio de Janeiro, a. 4, n. 7-8, p. 125-134, 1999.
} 
instituição, é que será sua referência perante os internos e os funcionários. Sem ela, ele não será conhecido, o que fará com que o adolescente submeta-se aos estereótipos da representação social que os demais fazem dele e os introjete, sejam eles negativos ou positivos.

Destarte, seja ela propositadamente construída ou atribuída pelos demais, uma nova identidade emerge da experiência institucional.

Ocorre que esse novo papel, condizente com as necessidades de uma vida institucionalizada, é diametralmente oposto ao que se associa à vida livre, chocando-se o jovem com a realidade que encontra após sua liberação. Esse sujeito não sabe como viver nesse novo mundo, o que aflorará sentimentos de inferioridade e de baixa autoestima. Ademais, a própria sociedade ajudará a reforçar essas sensações por meio da produção da estigmatização, da limitação das possibilidades de consumo, da exclusão do mercado de trabalho, do ambiente escolar e de tantas outras dificuldades com as quais ele irá depararse.

Fato é que, continua Silva,

$$
\begin{aligned}
& \text { a institucionalização total e prolongada cria, para a criança e para o adolescente, } \\
& \text { um quadro de referências que permeia toda a sua vida cognitiva, afetiva e } \\
& \text { emocional, que norteia todas as suas relações e que dita as suas respostas } \\
& \text { comportamentais. Enquanto interna, toda a busca da pessoa por aprovação, } \\
& \text { valoração e reconhecimento se dá dentro deste quadro de referências que é a } \\
& \text { antítese da vida, pois valoriza atitudes, comportamentos e coisas que fora da } \\
& \text { instituição são rejeitadas e estigmatizadas }{ }^{742} \text {. }
\end{aligned}
$$

A implementação de uma carreira criminosa, todavia, não se desenvolve ao acaso ou automaticamente. O sujeito pode ser levado a querer assumir uma vida delinquente por meio do desenvolvimento de motivos e interesses socialmente aprendidos ${ }^{743}$.

Os diferentes graus de sensibilidade às exigências do papel atribuído ao sujeito dependem de sua maturidade, razão pela qual todo esse processo que se inicia com a estigmatização e alcança seu ápice com o mergulho no papel criminal, princípio de uma carreira do gênero, atinge sua potencialidade máxima quando aplicado a adolescentes ${ }^{744}$.

\footnotetext{
${ }^{742}$ SILVA, Roberto da. O que é institucionalização/prisionalização. Discursos Sediciosos: crime, direito e sociedade, Rio de Janeiro, a. 4, n. 7-8, p. 125-134, 1999. p. 128.

${ }^{743}$ Importante que se destaque, mais uma vez, que não se trata de algo mecânico, determinista, como defendem alguns críticos do labelling approach. O que ocorre é que a experiência criminal do sujeito, seu contato com outros infratores, faz com que ele opte por assumir o caminho ilícito.

${ }^{744}$ Nesse sentido assevera Shoemaker que uma mudança de atitude proveniente do etiquetamento pode ser verificada, especial e mais fortemente, nos sujeitos menos comprometidos com a delinquência e que tiveram contato com o sistema mais precocemente. Cf. SHOEMAKER, Donald J. Theories of deliquency: an examination of explanations of delinquent behavior. 3. ed. Nova Iorque: Oxford University, 1996.
} 
Antes de se engajar numa atividade o indivíduo não pode dimensionar o prazer que ela lhe proporcionará, porém, no curso da interação com delinquentes mais experientes, ele aprende, informa-se sobre novas experiências delitivas e a como encará-las de maneira prazerosa $^{745}$, acabando por assumi-la como adequada para si.

O fato de a pessoa ter sido capturada e rotulada como desviante, ocasiona mudanças em todos os aspectos de sua vida. O estigma de ex-detento ou de ex-interno transformará sua autoimagem, sua imagem pública e trará consequências em sua futura participação social.

Pode ser que o sujeito identifique-se com sua etiqueta e comporte-se em conformidade com ela, como uma profecia que se autocumpre - self-fulfilling profecy na definição proposta pela teoria. A rotulação negativa leva à suspeição, por parte dos demais, da recidiva nas práticas deliquenciais, ou seja, ela catalisa as respostas e expectativas sociais, antecipando o comportamento futuro do estigmatizado, o que aumenta a probabilidade de um novo processo formal, capaz de reafirmar a etiqueta imposta ${ }^{746}$.

O estigmatizado, então, tende a ser isolado da participação em grupos sociais considerados convencionais, não pela característica ou natureza de seu ato, não porque sua conduta impeça isso, mas pelo conhecimento e reação dos demais, o que faz com que ele não consiga conciliar sua nova condição com outras normas que ele não tinha intenção de desrespeitar $^{747}$.

Desse modo, efetiva-se a profecia quando a expectativa do ambiente circundante determina, em medida notável, o comportamento do indivíduo.

Um último passo na consolidação dessa carreira consiste na incorporação do sujeito a um grupo desviante, o qual solidifica sua identidade desviada, tendo em vista a congruência da opção delitiva existente em todos os seus membros. Esses agrupamentos, entre outros fatores, tendem a racionalizar sua posição, criando justificações históricas, legais e psicológicas para sua escolha e a apresentar ao indivíduo formas mais seguras de

\footnotetext{
${ }^{745}$ BECKER, Howard S. Outsiders: studies in the sociology of deviance. Nova Iorque: The Free Press, 1997.

${ }^{746}$ SHOEMAKER, Donald J. Theories of deliquency: an examination of explanations of delinquent behavior. 3. ed. Nova Iorque: Oxford University, 1996.

${ }^{747}$ BECKER, Howard S. Outsiders: studies in the sociology of deviance. Nova Iorque: The Free Press, 1997. Para exemplificar tal situação Becker relata a condição de um usuário de drogas, caso este que pode ser perfeitamente estendido ao de um ex-interno. Conta que ele pode exercer uma atividade profissional indepententemente de seu vício, mas que ao saberem disso, pode ser que não se permita mais a continuação de seu trabalho em determinada empresa e em nenhuma outra. Assim, ele acaba obrigando-se a cometer crimes patrimonias para conseguir os recursos necessários ao seu sustento, algo que ele não tinha intenção de fazer. Cf. BECKER, Howard S. Outsiders: studies in the sociology of deviance. Nova Iorque: The Free Press, 1997.
} 
cometimento de ilícitos, oferecendo meios para que ele concretize de vez sua carreira criminosa $^{748}$.

Não obstante todo o desenho da construção da identidade criminal explanado, existem fatores de proteção que podem interromper a sequência desfavorável propiciada pelos fatores de risco, fazendo com que se inicie uma nova série de eventos que pode aumentar as possibilidades do sujeito adotar um estilo de vida pró-social ${ }^{749}$.

Para Garrido são exíguos os fatores de proteção puros, ou seja, que em nenhum de seus pólos de atuação geram a possibilidade de risco de assunção de condutas antissociais, sendo por isso mais correto falar de funções protetoras de determinados eventos. Verificase essa função, por exemplo, na formação de vínculos sólidos com pessoas significativas, sejam elas os pais ou companheiros, experiências educacionais ou aprendizagem de habilidades profissionais positivas, elevada autoestima, entre outras ${ }^{750}$.

São experiências dessa natureza que podem obstruir a reação em cadeia gerada pelos fatores de risco, impedindo, em qualquer momento em que se apresentem, a continuação da carreira criminal.

Em contrapartida, o sucesso do mergulho no papel criminal pode ser acelerado e tornado mais fácil se presentes condições objetivas para tanto. Ou seja, a alteração do eu torna-se mais provável diante da existência de uma estrutura que a permita, de uma realidade social atuando como laboratório de transformação do indivíduo. O melhor deles: a reclusão $^{751}$.

Em razão disso é que teóricos do labelling approach defendem que para confirmar alguém numa carreira criminosa basta colocá-lo com outros criminosos por tempo suficientemente longo para que ele se torne completamente saturado com todo o seu discernimento emocional e ético e para que ele divida as experiências criminais com seus novos amigos na prisão ${ }^{752}$.

Portanto, a internação, ao gerar o estigma que inicia todas as mudanças na imagem que a sociedade e o recluso mesmo têm de si próprio, ao tolher o contato do sujeito com os membros da "sociedade livre", ao colaborar com a formação dos grupos desviantes, por

\footnotetext{
${ }^{748}$ BECKER, Howard S. Outsiders. Studies in the sociology of deviance. Nova Iorque: The Free Press, 1997.

${ }^{749}$ GARRIDO, Vicente. Qué és la Psicología Criminológica. Madri: Biblioteca Nueva, 2005.

${ }^{750}$ GARRIDO, Vicente. Qué és la Psicología Criminológica. Madri: Biblioteca Nueva, 2005.

751 PATERNOSTER, Raymond; IOVANNI, Leeann. The labeling perspective and delinquency: An elaboration of the theory and an assessment of the evidence. In: CORDELLA, Peter; SIEGEL, Larry (Ed.). Readings in contemporary criminological theory. Boston: Northeastern University, 1996. p. 171-188.

${ }^{752}$ TANNEMBAUM, Frank. Crime and the community. Nova Iorque: Columbia University Press, 1951.
} 
permitir o estabelecimento do contato de sujeitos com interesses criminais, gera ao sujeito grande possibilidade de assumir uma identidade de infrator ${ }^{753}$.

O recolhimento de um jovem com outros infratores é um estímulo à educação para o crime. Toda a traumática experiência que o adolescente acabou de vivenciar em seu conflito com o Poder Judiciário - sua audiência, sua apreensão - faz com que essas lembranças sejam as mais marcantes que ele tem naquele momento e com que ele tenha vontade de dividi-la com os demais, trocar informações sobre o recolhimento e as infrações cometidas. A experiência institucional representa, então, a concentração de estímulo adaptada para o desenvolvimento de interesses delinquentes ${ }^{754}$.

Nesse diapasão assevera Saraiva que,

se fosse possível estabelecer uma tabela de comprometimento da conduta de um adolescente em uma escala de um a dez, não seria exagerado afirmar que, a 'melhor unidade de internação', com a 'melhor proposta pedagógica', estará apta a devolver um adolescente ao convívio social em um grau de comprometimento cinco, haja vista as inevitáveis seqüelas que resultam de um convívio com outros adolescentes autores de condutas infracionais graves e elevado índice de comprometimento $^{755}$.

Por tudo isso é que, na concepção da teoria do labelling approach, a experiência institucional juvenil assenta as bases para a futura carreira do criminoso ${ }^{756}$.

Privados de liberdade, convivendo em ambientes de regra promíscuos (desencadeadores, não raras vezes, de violência física, psíquica e sexual) e aprendendo as normas próprias dos grupos marginais (especialmente no que tange a responder com violência aos conflitos do cotidiano), a probabilidade (quase absoluta) é de que os adolescentes acabem absorvendo a chamada identidade do infrator, passando a se reconhecer, definitivamente, como pessoas cuja história de vida, passada e futura, resta indestrutivelmente ligada à delinquiência (os irrecuperáveis, como dizem eles). Dessa forma, quando da desinternação, certamente estaremos diante de cidadãos com categoria social piorada, ainda mais predispostos a condutas violentas e anti-sociais ${ }^{757}$.

Não se pode deixar de consignar que o agudo processo de oscilação que tem lugar entre ação e reação negativa, alcança com a internação em uma instituição juvenil seu

\footnotetext{
${ }^{753}$ FRASSETO, Flávio Américo. Esboço de um roteiro para aplicação das medidas socioeducativas. Revista Brasileira de Ciências Criminais, São Paulo, a. 7, n. 26, p. 159-195, abr./jun. 1999.

${ }^{754}$ TANNEMBAUM, Frank. Crime and the community. Nova Iorque: Columbia University Press, 1951.

${ }^{755}$ SARAIVA, João Batista Costa. Compêndio de Direito Penal Juvenil: adolescente e ato infracional. 3. ed. Porto Alegre: Livraria do advogado, 2006. p. 171.

${ }^{756}$ TANNEMBAUM, Frank. Crime and the community. Nova Iorque: Columbia University Press, 1951.

${ }^{756}$ SARAIVA, João Batista Costa. Compêndio de Direito Penal Juvenil: adolescente e ato infracional. 3. ed. Porto Alegre: Livraria do advogado, 2006.

${ }^{757}$ SOTTO MAIOR NETO, Olympio de Sá. Garantias penais do adolescente autor de ato infracional. In: ILANUD et al. (Org.). Justiça, adolescente e ato infracional: socioeducação e responsabilização. São Paulo: ILANUD, 2006. p. 135.
} 
ponto mais crítico $^{758}$, exercendo a violência desproporcional em seu trato um papel fundamental.

A violência simbólica representada por um tratamento humilhante e degradante é uma das principais causas da violência reativa por parte dos educandos ${ }^{759}$. Muitas vezes reproduzida pelo jovem, ela não é somente algo que está dentro dele, mas também uma reação sua ante as condições externas ${ }^{760}$, razão pela qual se pode asseverar que "a violência institucional tem produzido adolescentes que fazem rebeliões, reféns e circulam raivosos pelas ruas das cidades" ${ }^{761}$.

Por tudo isso, parece mais evidente, então, que o encarceramento seja mais propenso a causar a socialização secundária e não a ressocialização ${ }^{762}$. Indene de dúvidas, pois, que o labelling approach desacredita o fim de ressocialização atribuído à pena, mormente quando ela implica a privação da liberdade do jovem.

A obtenção de efeitos favoráveis advindos da reclusão, para aquele que a sofre, é algo irrealizável. A reeducação por meio da contenção é uma quimera.

Nas lições de Ferrajoli

o cárcere, em particular, é um lugar criminógeno de educação e solicitação ao crime. Repressão e educação são, em resumo, incompatíveis, como também o são a privação de liberdade e a liberdade em si, que da educação constitui a essência e o pressuposto, razão pela qual a única coisa que se pode pretender do cárcere é que seja o mínimo possível repressivo e, portanto, o menos possível dessocializante e deseducativo ${ }^{763}$.

Certo é que "não há como se desenvolver um trabalho terapêutico num ambiente de contenção, onde a individualidade da pessoa é naturalmente inibida",764.

Tannenbaum faz uma importante análise dos objetivos de um modelo de educação para o cárcere. Relata que o citado sistema educacional deve, de modo principal, prevenir a

758 RÜTHER, Werner. La criminalidad (o el "delincuente") a traves de las definiciones sociales (o etiquetamiento). Doctrina Penal: Teoría y Práctica en las Ciencias Penales, Buenos Aires, v. 1, n. 1-4, p. 749-764, 1978.

${ }^{759}$ COSTA, Antônio Carlos Gomes da. Natureza e essência da ação socioeducativa. In: ILANUD et al. (Org.). Justiça, adolescente e ato infracional: socioeducação e responsabilização. São Paulo: ILANUD, 2006.

${ }^{760}$ SANTOS, Maria Celeste Cordeiro Leite. Raízes da violência na criança e futuros danos psíquicos. Revista da Faculdade de Direito da Universidade de São Paulo, São Paulo, v. 96, p. 331-346, 2001.

761 TEIXEIRA, Maria de Lourdes Trassi. Evitar o desperdício de vidas. In: ILANUD et al. (Org.). Justiça, adolescente e ato infracional: socioeducação e responsabilização. São Paulo: ILANUD, 2006. p. 444.

${ }^{762}$ BERGALLI, Roberto. Crítica a la Criminologia: hacia una teoría crítica del control social en América Latina. Bogotá: Temis, 1982.

${ }^{763}$ FERRAJOLI, Luigi. Direito e Razão: teoria do Garantismo Penal. Tradução de Ana Paula Zomer Sica et al. 2. ed. São Paulo: Revista dos Tribunais, 2006. p. 253.

${ }^{764}$ FRASSETO, Flávio Américo. Esboço de um roteiro para aplicação das medidas socioeducativas. Revista Brasileira de Ciências Criminais, São Paulo, a. 7, n. 26, p. 159-195, abr./jun. 1999. p. 186. 
deteriorização do preso provocada por seu confinamento, ou seja, evitar sua exacerbada introspecção, a substituição de interesses reais por imaginários, ou mesmo sua tendência a "viver no passado". Em segundo lugar, deve desconstruir os hábitos indesejados ostentados pelo sujeito quando da sua entrada na instituição e substituí-los por hábitos desejáveis. Em terceiro, deve apresentar a ele novas atividades, novos conhecimentos, fazendo despertar novos hábitos e interesses. No entanto, o próprio autor confessa a grande dificuldade em se implementar um programa dessa natureza, tendo em vista as próprias condições e consequências que resultam do aprisionamento: a criação de novos hábitos e as adaptações ao ambiente institucional que elidem a reconstrução de seu caráter, de sua personalidade ${ }^{765}$.

Fato é que prisão é falha tanto como instituição educacional quanto como instituição disciplinar. Isso porque, no tocante ao primeiro ponto, não se verifica que o indivíduo lá recolhido esteja melhor assessorado para assumir um comportamento mais honesto do que o que ostentava antes do cometimento da infração. Em relação ao segundo, a desordem verificada no cárcere, o uso de meios cruéis de punição, a ocorrência de crimes em seu interior, entre outras mazelas, são por si sós suficientes para evidenciar a citada ineficiência ${ }^{766}$.

Não se olvide, ademais, que a organização e administração formais de uma instituição repressiva é suplementada por regras contraculturais da comunidade prisional, que se compõem por "respostas dinâmicas dos reclusos a função de segurança e aos padronizados procedimentos de massa incorporados a estrutura social formal da prisão" ${ }^{, 767}$. E nesse sentido,

dizer que as instituições totais constituem-se em escolas de criminalidade, e que juntas compõem um ciclo de formação da criminalidade, quer dizer que nesses universos institui-se uma contracultura, cujos valores, símbolos e representações concorrem para a construção de identidades institucionais que são, sobretudo, negativas, criminosas $^{768}$.

Portanto, não se pode mais negar que

as instituições de detenção têm efeitos que são hostis à reeducação e reinserção do condenado na sociedade e favoráveis à sua mais permanente inserção na população criminosa. A prisão é contrária a toda idéia moderna sobre educação, porque estas idéias são baseadas no individualismo e no auto-respeito individual, alimentado pelo respeito que o educador tem pelo educado. As cerimônias degradantes no começo da detenção, pelas quais o prisioneiro é despido dos símbolos de sua própria autonomia, são o oposto de tudo isto. A educação é

\footnotetext{
${ }^{765}$ TANNEMBAUM, Frank. Crime and the community. Nova Iorque: Columbia University Press, 1951. ${ }^{766}$ TANNEMBAUM, Frank. Crime and the community. Nova Iorque: Columbia University Press, 1951.

${ }^{767}$ LEMERT, Edwin M. Social Pathology: a systematic approach to the theory of sociopathic behavior. 1. ed. Nova Iorque: Toronto: Londres: McGraw-Hill, 1951. p. 314.

${ }^{768}$ SILVA, Roberto da. Os Filhos do Governo: A formação da identidade criminosa em crianças órfãs e abandonadas. São Paulo: Ática, 1997. p. 147.
} 
baseada no sentimento de liberdade e espontaneidade do indivíduo; a vida na prisão, como um universo de disciplina, tem um caráter repressivo e nivelador ${ }^{769}$.

Ainda nesse sentido afirma Zaffaroni que a imersão cultural que se consubstancia no cárcere

não pode ser interpretada como uma tentativa de reeducação ou algo parecido ou sequer aproxima-se do postulado da 'ideologia do tratamento'; suas formas de realização são totalmente opostas a este discurso, cujo caráter escamoteador é percebido até pelos menos avisados ${ }^{770}$.

Ademais,

não se imagine que a instituição total seja em si mesma apta a tratamento e emenda, uma vez que a ressocialização só se dará efetivamente por meio de atividades no mundo externo à unidade, quando se estabelecer convívio sadio - e com oportunidades - do adolescente na comunidade em que vive $\mathrm{e}^{771}$.

Assim é que as únicas lições que podem satisfatoriamente ser ministradas no ambiente de privação de liberdade são a educação para ser criminoso e a educação para ser um bom interno ${ }^{772}$. O que a instituição juvenil consegue - e com louvor - é estabelecer uma importante ligação entre educar o jovem e fazer emergir dele um criminoso profissional $^{773}$.

\subsubsection{As carreiras criminais: conexão entre internação e a pena privativa de liberdade na formação da identidade delinquente}

Pretende-se, neste excerto, apresentar um estudo qualitativo longitudinal, uma abordagem biográfica da vida criminal de alguns adultos que enveredaram na prática ilícita ainda jovens, após serem submetidos ao sistema de justiça juvenil.

\footnotetext{
${ }^{769}$ BARATTA, Alessandro. Marginalidade social e Justiça. Revista de Direito Penal, Rio de Janeiro, n. 2122, p. 5-25, jan.Ijun. 1976. p. 18.

${ }^{770}$ ZAFFARONI, Eugenio Raúl. Em busca das penas perdidas: a perda de legitimidade do sistema penal. Tradução de Vânia Romano Pedrosa e Amir Lopes da Conceição. 5. ed. Rio de Janeiro: Revan, 2001. p. 136.

${ }^{771}$ SOTTO MAIOR NETO, Olympio de Sá. Garantias penais do adolescente autor de ato infracional. In: ILANUD et al. (Org.). Justiça, adolescente e ato infracional: socioeducação e responsabilização. São Paulo: ILANUD, 2006. p. 135.

${ }^{772}$ BARATTA, Alessandro. Marginalidade social e Justiça. Revista de Direito Penal, Rio de Janeiro, n. 2122, p. 5-25, jan.Ijun. 1976.

${ }^{773}$ TANNEMBAUM, Frank. Crime and the community. Nova Iorque: Columbia University Press, 1951.
} 
Opta-se por esse tipo de aproximação tendo em vista ser uma metodologia já utilizada pelo labelling approach, bem como pelo interacionismo simbólico, propostas centrais no presente trabalho ${ }^{774}$.

Trata-se, pois, de conhecer o ponto de vista de alguém acerca do funcionamento de uma instituição ou de apreendê-lo por meio de sua própria experiência, de dar conta de seus sentimentos e percepções sobre uma experiência vivida ${ }^{775}$.

De forma a ilustrar o início de carreiras criminais possibilitadas pelos efeitos da internação na formação da identidade delinquente, serão relatados casos publicados em livros (autobiográficos ou não) acerca de indivíduos com histórias de vida construídas sobre a realidade criminal, nos quais serão relatadas as experiências vivenciadas nas instituições para jovens infratores, as quais pregam ter apenas e meramente uma finalidade educativa.

O relato ou a história de uma vida representa muito mais do que simplesmente isso. Não se refere apenas ao vivido de um sujeito, mas à vida em sociedade, permitindo-se a identificação em seu relato das particularidades de um momento social específico ${ }^{776}$.

A análise de conteúdo e de textos históricos refere-se a materiais produzidos no passado e que são, em muitas maneiras, dados e expressões acerca do comportamento que se quer reconstruir ou analisar. São esses métodos úteis a sugerir hipóteses, testá-las ou colaborar para o estabelecimento de uma perspectiva geral $^{777}$.

Insta salientar que não se trata aqui de uma amostra com pretensão de obtenção de resultados globais. Até porque, vale dizer, a pesquisa qualitativa não tem pretensão de representar o aspecto distributivo do fenômeno perquirido, não servindo à elaboração de generalizações $^{778}$. Trata-se aqui apenas da apresentação de alguns relatos ilustrativos acerca da realidade enfrentada por jovens em instituições destinadas a sua privação de

\footnotetext{
${ }^{774}$ Nesse sentido ver: SHECAIRA, Sérgio Salomão. Criminologia. 2. ed. rev. São Paulo: Revista dos Tribunais, 2008 e EINSTADTER, Werner J.; HENRY, Stuart. Criminological theory: an analysis of its underlying assumptions. 2. ed. Nova Iorque: Rowman \& Littlefield, 2006.

${ }^{775}$ PIRES, Álvaro P. Amostragem e pesquisa qualitativa: ensaio teórico e metodológico. In: SALLUM JÚNIOR, Basílio (Coord.). A pesquisa qualitativa: Enfoques epistemológicos e metodológicos. Petrópolis: Vozes, 2008. p. 154-211.

${ }^{776}$ HOULE, Gilles. A sociologia como ciência da vida: a abordagem biográfica. Tradução de Ana Cristina Nasser. In: SALLUM JÚNIOR, Basílio (Coord.). A pesquisa qualitativa: Enfoques epistemológicos e metodológicos. Petrópolis; Rio de Janeiro: Vozes, 2008. p. 317-334.

${ }^{777}$ CICOUREL, Aaron V. Method and measurement in Sociology. 2. imp. Nova Iorque: The Free Press, 1966.

${ }^{778}$ PAULILO, Maria Ângela Silveira. A pesquisa qualitativa e a história de vida. Serviço Social em Revista, Londrina, v. 2, n.1, jul./dez. 1999. Disponível em: <http://www.ssrevista.uel.br/?c_v2n1_pesquisa.htm>. Acesso em 07 dez. 2009.
} 
liberdade, para que seja permitido cotejar as informações dos narradores com os processos de criminalização propostos pela teoria do labelling approach.

\subsubsection{The Jack-Roller: A delinquent boy's own history ${ }^{779}$.}

O livro apresenta o relato do desenvolvimento da carreira criminal de um jovem delinquente, com o nome fictício de Stanley, o qual foi acompanhado pelo pesquisador durante seis anos, iniciando-se o estudo quando Stanley contava com dezesseis anos de idade e a ele havia sido concedido o benefício do livramento condicional, após mais uma de suas internações.

A pesquisa realizada por Shaw foi a precursora de uma série de estudos de caso realizados em Chicago empregando um método qualitativo de pesquisa em que se combinou a coleta de depoimentos orais sem estruturação prévia ou interferência do pesquisador - tendo sido inclusive a divisão de capítulos feita por Stanley -, com dados verificáveis em registros, visando avaliar e interpretar o depoimento pessoal ${ }^{780}$.

Durante toda sua infância Stanley viveu em bairros pobres de Chicago, no seio de uma família repleta de conflitos e tensões emocionais. Sua mãe havia morrido quando ele tinha quatro anos, seu pai era alcoólatra e sua relação com a madrasta era bastante desarmônica e conflituosa, sendo ela a considerada pelo menino a grande culpada por todos os percalços de sua existência.

Seu primeiro contato com o sistema de Justiça formal ocorreu bem cedo quando Stanley contava com seis anos e meio de idade, primeiro pelas suas fugas constantes de casa e depois pela prática de ilícitos.

Numa dessas evasões, quando tinha oito anos de idade, ele foi capturado e encaminhado para o Juvenile Detention Home.

Relata, num primeiro momento, ter gostado do local, pois lá ele tomou banho e foi alimentado. Depois percebeu tratar-se de uma instituição onde estavam recolhidos os mais variados "desonestos", os quais se consideravam já famosos no mundo do crime. Eles passavam os dias contando suas experiências e ambições criminais e disputando para ver quem era o melhor delinquente entre todos eles.

${ }^{779}$ SHAW, Clifford R. The Jack-Roller: A delinquent boy's own history. Chicago: The University of Chicago, 1992.

${ }^{780}$ NUNES, Jordão Horta. Interacionismo simbólico e dramaturgia: a sociologia de Goffman. São Paulo: Humanitas, 2005. p. 36. 
Nas conversas lá travadas Stanley descobriu crimes e modos de roubar que nem sequer imaginava existirem.

O jovem foi encaminhado ao Juvenile Detention Home por diversas vezes, pois era deixado em sua casa e em seguida encontrado novamente a vagar pela cidade.

Em seu primeiro julgamento, ainda com oito anos, Stanley destaca nem sequer ter conseguiu manifestar-se, tendo em vista estar assustado com a situação. O juiz ordenou que ele voltasse para sua casa, mas pouco tempo depois ele foi encontrado novamente na rua. Após mais algumas fugas, o magistrado determinou que Stanley fosse recolhido no Parental School por três meses.

A primeira noite do garoto na instituição foi também a primeira vez que ele confessou sentir grande tristeza e saudade de casa. A disciplina no local era bastante rígida sendo defesa a conversa entre os internos.

Após sua liberação Stanley voltou a ser encontrado nas ruas e o magistrado determinou seu internamento na St. Charles School for Boys, instituição em que, pôde verificar, a disciplina era ainda mais severa, sendo praticamente tudo proibido.

Lá a ele teve de aprender a defender-se da violência sexual que se direcionava precipuamente em detrimento dos meninos mais novos.

Passados dezesseis meses de internação Stanley foi liberado, sentindo-se muito pior do que entrou, sentindo-se mais rebelde e petulante.

Depois de nova fuga de casa ele voltou para a mesma instituição, mas, em decorrência de suas experiências anteriores com o sistema, sentia-se mais confiante e menos sensível com a reclusão. Stanley começava, disse ele, a ser mais sarcástico, "coração de pedra" e a ser encarado pelos outros como alguém já mais experiente no mundo do crime.

Agora era ele quem contava aos demais internos histórias sobre suas experiências criminosas, a maioria delas inventadas, já que apenas fugia de casa e praticava pequenos furtos para alimentar-se. Seus pensamentos, relata, começaram a afastar-se de virtudes e da vontade de se tornar um homem bom. Ele próprio questiona sobre como poderia reformarse num ambiente com tanta disciplina e frieza. Seu novo propósito era de enveredar pelo mundo do crime e não mais pensar em ser bondoso, em ser honesto.

Decorridos mais dez meses de internação, Stanley foi transferido para uma fazenda em Batávia, Illinois. 
Após liberado continuou sua rotina de fugas e pequenos furtos, tendo sido internado mais uma vez na Juvenile Detention Home e depois na St. Charles School for Boys, local onde ficou por mais dezoito meses.

Stanley conta que se sentia preso no trabalho e na escola e por isso, quando em liberdade, logo abandonava essas atividades. Ele gostava de ser livre, de passar as noites vendo as atrações das ruas, de viajar sem destino, e fazia isso constantemente.

Após ele e a gangue que acabara de instituir furtarem um bêbado, Stanley foi internado novamente. Por esse ilícito Stanley foi condenado a passar um ano em Illinois State Reformatory. Logo ele foi transferido para County Jail e depois para Pontiac.

Stanley relata que em Pontiac, pela primeira vez em sua vida, deu-se conta de que era um criminoso. Ele adorava juntar-se aos grupos e ouvir histórias sobre crimes. Sentiase humilhado por não ser um grande criminoso e decidiu que não atuaria mais em pequenos ilícitos, mas apenas em grandes empreitadas.

Ao deixar Pontiac Stanley foi morar com sua irmã. Estava decidido a tornar-se uma pessoa melhor e logo começou a trabalhar. Seu passado de ex-detento logo se espalhou entre os jovens da rua e em seguida para o bairro inteiro. Ele era evitado por todos e não tinha nenhum amigo. Stanley narra um acontecimento, visando a exemplificar o tratamento que recebia dos demais. Conta que certo dia estava em frente à casa de sua irmã e um carro veloz locomovia-se em direção a uma pequena menina. Sua mãe começou a gritar desesperadamente acreditando que sua filha seria morta. Ele salvou a criança e a entregou a sua mãe. Esta abraçou a menina, olhou para ele com sarcasmo, e, sem sequer agradecêlo, foi embora.

Depois disso Stanley deixou o bairro e passou a morar com amigos, companheiros de crimes. Após um roubo a diversas pessoas que se abrigavam em um prédio abandonado Stanley foi capturado pela polícia e enviado para internação em Bridewell.

Ao chegar à instituição, com dezesseis anos e nove meses, Stanley recebeu um papel com o tempo de sua condenação - um ano - e seu número de identificação. Nesse momento Stanley reflete: “com meu nome se foi o último vestígio de civilização. Quando eu pensei nisso eu senti que tinha perdido algo de valor para mim,"781.

${ }^{781}$ SHAW, Clifford R. The Jack-Roller: A delinquent boy's own history. Chicago: The University of Chicago, 1992. p. 149. 
Lá, mais uma vez conheceu grandes criminosos e apaixonou-se por suas histórias. Ele passava os dias tentando esquivar-se da monotonia da prisão e sonhando em ser um grande criminoso.

Sua revolta contra sua situação de vida só aumentava. Para ele era um insulto colocar qualquer ser humano numa cela como aquela em que ele estava, ainda mais ele, cuja madrasta era a grande culpada por tudo que ele passou. Stanley diz que na cadeia ele não apenas destruiu-se fisicamente, tornou-se fraco, nervoso, mas também desenvolveu reumatismo e pneumonia, além de subnutrição, os quais os levaram para o hospital. Suas idas e vindas ao hospital tornaram-se constantes, tendo que ficar por diversas vezes internado para recuperar-se.

Durante uma dessas recaídas, no hospital, ele refletiu sobre as injustiças de sua vida e sobre seu futuro.

Stanley asseverou que já havia perdido toda a esperança em sua regeneração e que só conseguia ver a sua frente crimes e grades de prisões. Disse que para isso foi educado, isso era tudo sobre o que sua mente conseguia pensar. Além do mais, todos os seus amigos eram criminosos e não se podia exigir que ele fosse diferente. Asseverou que enquanto todos tinham direito de existir e ele estava apenas lutando para viver. No crime acreditava ser independente, sendo que nos trabalhos braçais era apenas escravo de alguém.

Quanto à possibilidade de prisão disse que era mais experiente agora e que tomaria mais cuidado para não ser pego.

Agora ele sentia-se destinado ao crime. Relata que circunstâncias o levaram a cadeia toda vez que ele tentava fazer o bem, por isso havia perdido sua ambição e não se importava com nada além do crime. Stanley diz que foi educado no crime e que durante toda sua sentença só pensou em ser mais cuidadoso nessa prática para não mais ser pego.

Certo dia, no momento em que realizava uma tarefa, encontrou senhor Cone, seu oficial de condicional em St. Charles, o qual prometeu ajudá-lo com roupas e com um emprego quando ele estivesse livre. Após despedir-se dele Stanley sentiu uma nova esperança, achou que talvez o destino poderia mudar em seu favor.

$\mathrm{Na}$ noite anterior à sua soltura ele praticamente não dormiu, pensando no significado de sua liberdade que estava tão perto. Ao sair ele pisou no "mundo de fora", despedindo-se, segundo ele, daquele buraco que quase roubou sua vida. 
4.1.1.2. Os Filhos do Governo: A formação da identidade criminosa em crianças órfãs e abandonadas $^{782}$.

Esta obra é o resultado do ingresso de Silva no programa de mestrado da Universidade de São Paulo. A proposta do autor era pesquisar a institucionalização de crianças e adolescentes não apenas em conflito com a lei, mas também abandonados e órfãos ${ }^{783}$, tendo em vista ter vivenciado tal situação e, por conta disso, poder encará-la de modo diverso de qualquer outro pesquisador que não tenha tido essa experiência. Nas palavras do autor, sua ideia era investigar a

trajetória de institucionalização de uma geração de ex-menores da FEBEM, da qual eu também fizera parte, e as práticas pedagógicas que resultaram na criminalização de um número tão grande de crianças que antes não tinham nenhum histórico de infração ou de criminalidade ${ }^{784}$.

$\mathrm{Na}$ obra o autor mescla relatos de sua vida com pesquisas científicas acerca do histórico da etapa tutelar, dados dos sujeitos internados entre os nascidos de 1940 a 1968 e análise dos efeitos dessa disciplina sobre os menores.

Conta que seu contato com instituições para recolhimento de menores se iniciou precocemente, quando tinha cinco anos de idade e seu pai abandonou sua família. Sua mãe, não tendo condições econômicas de cuidar de seus filhos, teve todos eles abrigados em diferentes instituições, em virtude de suas idades e sexos.

Silva só tomou conhecimento da existência e da identidade de seus irmãos mais tarde, quando, facilitado por funcionários do Cartório onde trabalhou, teve acesso ao seu processo.

Já tendo passado ao longo de sua incipiente vida por diversas instituições, aos 15 anos, após ser designado para prestar serviços no Cartório do $1^{\circ}$ Oficio do Juizado de Menores, foi transferido para a FEBEM do Tatuapé. Todavia, no período vespertino, após findas suas atividades no Cartório, Silva empregou-se como office-boy em uma empresa. Quando funcionários da FEBEM descobriram sobre os seus dois empregos deduziram que o jovem já podia sustentar-se sozinho e o expulsaram da instituição.

\footnotetext{
${ }^{782}$ SILVA, Roberto da. Os Filhos do Governo: A formação da identidade criminosa em crianças órfãs e abandonadas. São Paulo: Ática, 1997.

${ }^{783}$ Destaque-se que a narrativa contida no livro refere-se a um momento histórico - durante a primeira etapa da especialização da Justiça de Menores - em que crianças e adolescentes infratores ou abandonados eram internados nas mesmas instituições.

${ }^{784}$ SILVA, Roberto da. Os Filhos do Governo: A formação da identidade criminosa em crianças órfãs e abandonadas. São Paulo: Ática, 1997. p. 26.
} 
Silva hospedou-se em uma pensão no bairro de Pinheiros, próximo ao seu local de trabalho, mas logo foi despejado por falta de pagamento. Sem ter para onde ir, sem familiares e um lar que o acolhesse, passou a dormir escondido no escritório da empresa onde trabalhava.

Nesse momento de sua vida Silva relata ter cometido sua primeira "delinquência": desviava o dinheiro da condução que lhe era entregue para a realização de seu serviço para alimentar-se. Seus atrasos constantes o denunciaram e tendo sido descoberto também que ele passava as noites no escritório, envergonhado, demitiu-se, tornando-se, aos dezesseis anos, um menino de rua.

Após algum tempo vivendo nas ruas de São Paulo decidiu mudar-se para Santos, cidade onde acreditava ter nascido. Lá foi apresentado a outros meninos de rua, à prostituição, às drogas, começou a frequentar as delegacias por pequenos furtos, teve contato com delinquentes adultos e conheceu o espancamento, a tortura e o afogamento, aplicados pelos policiais, mesmo sabendo tratar-se de um menor de idade.

Silva foi condenado e preso pela primeira vez no ano de 1979, já maior de idade, retornando ao cárcere por diversas vezes no decorrer de sua vida.

Na sua primeira prisão, no Pavilhão 9 da Casa de Detenção, surpreendeu-se ao encontrar diversos ex-menores, com os quais fora abrigado na infância, situação com a qual se deparou por inúmeras outras vezes, em distintas prisões ou pavilhões.

Durante seu recolhimento no Pavilhão 2 da citada penitenciária passou a cuidar da situação processual dos demais presos, redigindo as petições necessárias para pleitear os benefícios legais pretendidos.

Ao deixar a prisão definitivamente, no ano de 1984, engajado com a situação vivenciada pelos presos, passou a dar palestras e entrevistas sobre a realidade com a qual havia se deparado por todos esses anos de institucionalização.

Ao sofrer represálias por sua atuação decidiu dedicar-se aos estudos, tendo ingressado no curso de Pedagogia da Universidade Federal do Mato Grosso, com aprovação em primeiro lugar no vestibular. Finda sua graduação iniciou seu mestrado na Universidade de São Paulo, focando sua pesquisa, conforme mencionado, no estudo de sua vida, aqui apresentada.

Silva dedicou-se a sua carreira acadêmica e hoje é professor na Universidade de São Paulo. 
4.1.1.3. Memórias de um sobrevivente ${ }^{785}$

Luiz vem de uma família bastante modesta - seu pai era alcoólatra e sua mãe uma mulher extremamente submissa. Sua relação com o pai era bastante conflituosa, pois este se tornava muito violento quando consumido pela bebida.

Luiz não gostava da escola, adorava a liberdade, era fascinado pelo brilho das "luzes da cidade", como dizia ele. Encantava-se com os cinemas, bares, restaurantes, casas de prostituição, bebidas e drogas. Por isso, fugas de casa para desfrutar da liberdade, viagens, furtos, roubos, contatos com a polícia e com o Juizado de Menores permearam toda a sua história.

Já aos doze anos evadiu-se do colégio e de sua casa levando consigo o dinheiro destinado ao adimplemento da mensalidade escolar. Após voltar para casa foi obrigado a trabalhar, mas fugiu novamente, levando agora as finanças da empresa que o empregara.

Seu contato com a Polícia começou cedo. Os policiais o ameaçavam e após alguns socos e pontapés o devolviam às ruas. Por vezes, confiscavam o dinheiro que sabiam ser produto dos furtos que praticava no centro de São Paulo e o liberavam.

Logo - no início da adolescência - também conheceu a tortura praticada nos meios policiais: palmatória, choques, "pau-de-arara", pauladas, pancadas com o fio de telefone e com borracha de pneu de caminhão.

Em uma de suas apreensões, foi internado no RPM - Recolhimento Provisório de Menores -, onde a disciplina era rígida, à base do terror, e os menores tratados com insultos. Luiz conta que logo no dia de sua chegada foi agredido com um fio de telefone, o qual era utilizado pelos funcionários da instituição como um chicote. Vivia apanhando dos internos mais velhos e lutando contra eles pela preservação de sua liberdade sexual.

Relata que foi, aos poucos, perdendo seu jeito meigo e infantil e introjetando em seu comportamento o ambiente violento da instituição. Confessa que talvez até estivesse, se não fosse pequeno, abusando dos meninos menores, tal qual faziam com ele.

Durante a internação trabalhou numa oficina de marcenaria, na horta e como pedreiro, sendo que essas duas últimas atividades permitiam sua saída do RPM durante o dia.

${ }^{785}$ MENDES, Luiz Alberto. Memórias de um sobrevivente. 2.reimp. São Paulo: Companhia das Letras, 2005. 
Após uma entrevista com a equipe técnica da instituição, acreditando veementemente que seria liberado, foi proibido de realizar atividades externas e transferido para a triagem, local onde ficavam os menores considerados mais "perigosos".

Já no segundo dia no local foi espancado por garotos que queriam estuprá-lo e ao não os delatar para os funcionários apanhou destes também. Mas não foi um acontecimento isolado, uma vez que séries de espancamentos como essa se repetiram por inúmeras vezes durante sua permanência na instituição.

Fica patente em sua narrativa que sua revolta só aumentava com o passar dos dias e dos meses. Nesse sentido relata:

todas as minhas boas intenções de trabalhar, viver com meus pais numa boa, foram-se evaporando na medida exata dos dias que ia passando no inferno. Julgava-me traído, roubado, e pensava que não merecia tudo o que passara. Uma revolta densa ia tomando conta de meu ser. Queria agora era ser bandido mesmo. Viver armado para nunca mais me sentir indefeso ${ }^{786}$.

Da triagem foi transferido para o Instituto de Menores de Mogi-Mirim.

Lá trabalhou na lavoura e na cozinha. Juntou-se a uma "sociedade" dentro da instituição, o que lhe conferia prestígio e proteção.

Sobre o projeto reeducativo desenvolvido na instituição relata que "a sociedade da época, enganada, julgava que estávamos sendo reeducados. Mas estávamos era desenvolvendo, ampliando e trocando nossos conhecimentos relacionados com o crime" ${ }^{, 787}$.

Apenas meses depois de completar dezoito anos Luiz foi liberado e levado de volta para São Paulo. Em pouco tempo, quando começou a se enturmar com os jovens do bairro, voltou a furtar, para poder sair, gastar com os amigos. Nesse momento confessa já havia desistido de todas suas intenções de arranjar um emprego e viver honestamente.

Não demorou muito para ser levado à delegacia, onde passou alguns dias encarcerado, tendo sido liberado apenas após ter prometido dar dinheiro aos policiais.

Essas apreensões tornaram-se constantes em sua vida adulta. Agora Luiz havia decidido tornar-se um assaltante, a cometer roubos com uso de arma de fogo. Uniu-se a uma "quadrilha" e assim o fez.

Os assaltos tornaram-se constantes, visando a manter seus luxos; por vezes, duas ou três vezes por semana. Boates, passeios, roupas e mulheres eram sua vida.

${ }^{786}$ MENDES, Luiz Alberto. Memórias de um sobrevivente. 2.reimp. São Paulo: Companhia das Letras, 2005. p. 154.

${ }^{787}$ MENDES, Luiz Alberto. Memórias de um sobrevivente. 2.reimp. São Paulo: Companhia das Letras, 2005. p. 180. 
Numa de suas apreensões, foi preso na Casa de Detenção, o que ocorreu mais de uma vez. Saiu de lá, definitivamente, já um homem, com mais de cinquenta anos de idade. 


\section{CONCLUSÃO}

A teoria do labelling approach revelou a engrenagem que faz o sistema de justiça penal funcionar: as relações de poder, ou a ausência dele como critério reitor da seleção, as desigualdades na persecução que realiza, os processos de criminalização, bem como os problemas decorrentes de sua intervenção. Em outras palavras, por meio dela, manifestaram-se a falsidade do discurso e da intervenção jurídico-penal.

Essa Criminologia propiciou que fosse lançado um novo olhar sobre a atuação dos sistemas de justiça, cambiando a visão que se tinha anteriormente sobre seus elementos. $\mathrm{O}$ crime passou a ser compreendido como um comportamento assim definido por conta das relações de poder que permitem aos poderosos imporem suas visões morais sobre as condutas; o criminoso passou a ser encarado como um ser em tudo e por tudo igual aos demais, sendo o rótulo de delinquente uma mera imposição do corpo social, resultado de sua reação a um comportamento; e a pena, verificou-se, não combate a criminalidade, mas a cria e facilita a sua reprodução.

Contudo, essa lógica do sistema de justiça penal não é particular dos adultos. Não se infere nenhuma diferença no que se refere à perquirição da mal dita delinquência juvenil.

As medidas socioeducativas impostas aos jovens em conflito com a lei não são qualitativamente diversas das penas aplicadas aos adultos. Aquelas certamente - e estas também - devem ser guiadas por um programa educativo que possibilite a apresentação de conhecimentos e valores positivos aos adolescentes, mas isso não retira sua natureza de sanção, com todos os problemas inerentes a uma coerção institucionalizada.

O jovem submetido ao controle social formal é também rotulado, estigmatizado, podendo ser essa sua experiência, mormente quando se trata da internação, apta a transformá-lo em alguém diferente do que ele era.

Isso porque, conforme já se evidenciou, os maiores efeitos do processo de institucionalização são os danos causados à formação da identidade do jovem, a mudança no modo como ele se enxerga e como é encarado pela sociedade, a redução de sua autoestima, a exasperação de seu conflito com a lei e a facilitação do desenvolvimento de uma carreira criminosa. 
O sistema penal tem a capacidade de adentrar nas esferas mais particulares do indivíduo e mudar seus valores, suas crenças e sua personalidade. Ele se irradia por todos os espaços, provocando uma transformação radical na vida do que a ele se submeteu. E esse dado é fundamental para que se repense o tratamento dispensado aos jovens em conflito com a lei.

Devolver as responsabilidades à sociedade civil e deixar a justiça como último recurso parecem ser uma boa opção desde o ponto de vista político-criminal ${ }^{788}$. Uma sociedade que não cuida do saudável desenvolvimento de suas crianças e adolescentes, que não lhes proporciona condições dignas de sobrevivência, que lhes tolhe o direito a ter uma educação de qualidade não pode hipocritamente pretender “corrigi-los" mais tarde, após terem manifestado um comportamento não desejado.

A intervenção desmedida e a política de internação dos jovens já realizadas sob a égide da doutrina da Situação Irregular provou os frutos que pode produzir: a criminalização da miséria, uma geração de crianças institucionalizadas e o aprofundamento dos problemas sociais enfrentados por esses sujeitos.

Consoante os ensinamentos do labelling approach, a intervenção estatal é sempre danosa e por isso deve ser evitada, especialmente quando se trata de jovens cujo processo de desenvolvimento ainda não se findou.

Não se pode crer ingenuamente que a intervenção coercitiva do Estado sobre a esfera de liberdade de um jovem é a solução para se pôr fim ao fenômeno da infração juvenil. Não se pode ainda iludir-se com a falácia do fim de proteção do jovem e crer que a experiência que vivenciou não trará qualquer consequência na conformação de sua identidade.

Fato é que

\begin{abstract}
devemos considerá-los como jovens e adolescentes e não como infratores. Dependendo de como os considerarmos e nos relacionarmos com eles, o processo de socialização e educação que compreendermos será uma experiência de vida que contribuirá para que iniciem a construção de outra forma de vida e assumam construir-se e construir seus projetos de vida não com base no fracasso e na rejeição a si mesmos e ao mundo que os rodeia, mas com base nas potencialidades que descobriram possuir e nos desafios de uma vida melhor do que a que estavam vivendo ${ }^{789}$.
\end{abstract}

\footnotetext{
${ }^{788}$ GIMÉNEZ-SALINAS COLOMER, Esther. La justicia de menores en el siglo XX: uma gran incógnita. In: BUSTOS RAMÍREZ, Juan (Dir.). Un Derecho Penal del Menor. Santiago de Chile: Conosur, 1992.

${ }^{789}$ GONZALEZ, Alberto Brusa. Experiências socioeducativas bem-sucedidas: subsídios para a discussão de políticas públicas nas unidades de internação socioeducativas (UISE). In: ILANUD et al. (Org.). Justiça, adolescente e ato infracional: socioeducação e responsabilização. São Paulo: ILANUD, 2006. p. 542.
} 
O que se faz aqui é muito mais trazer á baila a problemática que envolve a responsabilização da adolescência brasileira do que propor soluções mirabolantes para resolver a questão. Tomando emprestadas as palavras de Rosa, pode-se dizer que "talvez muitos se decepcionem de cara com esse escrito. Não traz propostas milagrosas de aplicação fácil e simples do Estatuto da Criança e do Adolescente. Comprimidos se vendem em farmácia, ou em livros de autoajuda jurídicos"790.

A missão que se pretendeu cumprir aqui foi a de despertar a atenção para a danosidade da atuação do controle social formal sobre o jovem e, portanto, da necessidade de utilizá-lo excepcionalmente. Se isso for observado pelos leitores da presente dissertação, este trabalho e esta autora terão cumprido seu objetivo.

${ }^{790}$ ROSA, Alexandre Morais da. Introdução crítica ao ato infracional: princípios e garantias constitucionais. Rio de Janeiro: Lumen Juris, 2007. 


\section{BIBLIOGRAFIA}

AGRA, Cândido Mendes Martins da. Instituições para jovens delinquentes no Québec, Canadá. Revista Portuguesa de Ciência Criminal, Coimbra, v. 2, n. 2, p. 227-246, abr./jun. 1992.

AKERS, Ronald L. Criminological Theories: introduction and evaluation. 2. ed. Los Angeles: Roxbury, 1997.

ALBUQUERQUE, Catarina de. Os direitos da Criança em Portugal e no mundo globalizado: o princípio do interesse superior da criança. Direito das Crianças, Coimbra, $\mathrm{n}$. 3, p. 39-63, 2004.

AMAR, Ayush Morad. Temas de Criminologia. São Paulo: Resenha Universitária, 1982. v. II.

ANDRADE, Vera Regina Pereira de. Do paradigma etiológico ao paradigma da reação social: mudança e permanência de paradigmas criminológicos na ciência e no sendo comum. Revista Brasileira de Ciências Criminais, São Paulo, v. 4, n. 14, p. 276-287, abr./jun. 1996.

A ilusão da segurança jurídica: do controle da violência à violência do controle penal. 2. ed. Porto Alegre: Livraria do Advogado, 2003.

Por que a criminologia (e qual criminologia) é importante no ensino jurídico? Carta Forense, São Paulo, n. 58, p. 22-23, mar. 2008.

ANITUA, Gabriel Ignacio. Histórias dos pensamentos criminológicos. Tradução de Sérgio Lamarão. Rio de Janeiro: Revan, 2008. (Instituto Carioca de Criminologia. Coleção Pensamento Criminológico, 15). 
ARAGÃO, Antonio Moniz Sodré de. As três escolas penais: clássica, antropológica e crítica. 8. ed. Rio de Janeiro: Freitas Bastos, 1977.

ARANDA, Fernanda. Cresce apreensão de menores de 14. O Estado de São Paulo, São Paulo, 12 dez. 2008. Cidade, p. 1.

ARAUJO, Fernanda Carolina de. Maioridade Penal: aspectos criminológicos. In: SÁ, Alvino Augusto de; SHECAIRA, Sérgio Salomão. Criminologia e os problemas da atualidade. São Paulo: Atlas, 2008. p. 19-50.

ARGYLE, Michael. A interação social: relações interpessoais e comportamento social. Tradução de Márcia Bandeira de Mello Leite Nunes. Rio de Janeiro: Zahar, 1976.

BANDEIRA, Gonçalo Nicolau Cerqueira Sopas de Melo. O direito de intervenção junto de menores infratores como: direito do facto, direito do autor, ou direito do autor e do facto, direito penal ou direito não penal. Revista Portuguesa de Ciência Criminal, Coimbra, v. 13, n. 4, outIdez, 2003.

BARANGER, Thierry; SALAS, Denis. Le juge des enfants fait-il encore autorite? Archive de Politique Criminelle, Paris, n. 30, p. 25-35, 2008.

BARATTA, Alessandro. Marginalidade social e Justiça. Revista de Direito Penal, Rio de Janeiro, n. 21-22, p. 5-25, jan. Ijun. 1976.

Criminologia e Dogmática Penal. Passado e futuro do modelo integral da Ciência Penal. Revista de Direito Penal, Rio de Janeiro, n. 31, p. 5-37, jan. Ijun. 1981.

Principios del Derecho Penal Mínimo: para una teoría de los Derechos Humanos como objeto y límite de la ley penal. Doctrina Penal: Teoría y Práctica en las Ciencias Penales, Buenos Aires, v. 10, n. 37- 40, p. 623-650, 1987.

- La situación de la protección del niño en America Latina: líneas de una investigación-acción sobre los derechos de los niños. Capítulo Criminológico, Maracaibo, v. 18-19, p. 159-175, 1990-1991. 
Direitos humanos: entre a violência estrutural e a violência penal. Fascículos de Ciências Penais, Porto Alegre, v. 6. n. 2, p. 44-61, abr.Ijun. 1993.

. Elementos de un nuevo derecho para la infancia y la adolescência: a proposito del Estatuto del niño y del adolescente de Brasil. Capítulo Criminológico, Maracaibo, v. 23, n. 1, p. 1-18, jan. /jun. 1995.

¿Tiene futuro la Criminología Crítica? Reflexiones sobre el modelo integrado de las ciencias penales y la interdisciplinariedad externa. Capítulo Criminológico, Maracaibo, v. 23, n. 2 , p. 487-501, 1995.

. Os direitos da criança e o futuro da democracia. In: et al. Perspectivas do Direito no início do século XXI. Coimbra: Coimbra Editora, 1999, p. 61-91.

Criminologia crítica e crítica do direito penal: introdução à sociologia do direito penal. Tradução de Juarez Cirino dos Santos. 2. ed. Rio de Janeiro: Freitas Bastos, 1999. (Instituto Carioca de Criminologia. Coleção Pensamento Criminológico, 1).

BARBERO SANTOS, Marino. La delincuencia juvenil en España: imagen y realidad. Doctrina Penal: Teoría y Práctica en las Ciencias Penales, Buenos Aires, v. 6, n. 21-24, p. 417-436, 1983.

BATISTA, Vera Malaguti S. W. O proclamado e o escondido: a violência da neutralidade técnica. Discursos Sediciosos: crime, direito e sociedade, Rio de Janeiro, v. 2, n. 3, p. 7786, 1997.

Difíceis ganhos fáceis: Drogas e Juventude pobre no Rio de Janeiro. Rio de Janeiro: Freitas Bastos, 1998.

BECCARIA, Cesare. Dos delitos e das penas. Tradução de J. Cretella Jr. e Agnes Cretella. 3. ed. São Paulo: Revista dos Tribunais, 2006. 
BECKER, Howard S. Outsiders: studies in the sociology of deviance. Nova Iorque: The Free Press, 1997.

BELOFF, Mary. Algunas confusiones en torno a las consecuencias jurídicas de la conducta trangresora de la ley penal en los nuevos sistemas de justicia juvenil latinoamericanos. In: GARCÍA MENDÉZ, Emilio (Comp.). Adolescentes y Responsabilidad Penal. Buenos Aires: Ad-Hoc, 2001. p. 29-69.

BERGALLI, Roberto. Crítica a la Criminologia: hacia una teoría crítica del control social en América Latina. Bogotá: Temis, 1982.

Perspectiva sociológica: desarollos ulteriores. In: ; BUSTOS RAMÍREZ, Juan; MIRALleS, Teresa. El Pensamiento Criminológico: un análisis crítico. Bogotá: Temis, 1983. p. 109-131. v. 1.

Conflicto Social y control penal. Revista de la Facultad de Derecho Universidad Complutense, Madri, n. 11, p. 99-115, jun. 1986.

. Control y liberación en América Latina. Poder y Control: Revista hispanolatinoamericana de disciplinas sobre el control social, Barcelona, n. 1, p. 101-106, 1987.

. Controle social: suas origens conceituais e usos instrumentais. Revista Brasileira de Ciências Criminais, São Paulo, ano 1, n. 3, p. 31-38, jul.Iset. 1993.

La violencia del Sistema Penal. Revista Peruana de Ciencias Penales, Lima, ano 3, n. 5, p. 109-127, jan./jun. 1995.

. Garantías, sistema penal y exclusión social: una obra intelectual frente a la quiebra de los principios. In: BAIGÚN, David et al. Estudios sobre Justicia Penal. Buenos Aires: Del Puerto, 2005. p. 535-552.

; BUSTOS, Juan; MIRALLES, Teresa. Personalidade e Criminalidade. Revista IOB de Direito Penal e Processual Penal, Porto Alegre, ano 7, n. 42, p. 108-113, fev./mar. 2007. 
BIDWELL, Charles E. A juventude na sociedade moderna. Tradução de Octavio Mendes Cajado. In: PARSONS, Talcott (Org.). A Sociologia Americana. São Paulo: Cultrix, 1970. p. $285-299$.

BRAITHWAITE, John. The new regulatory state and the transformation of Criminology. In: GARLAND, David; SPARKS, Richard (Ed.). Criminology and Social Theory. Nova Iorque: Oxford University Press, 2000. p. 47-69.

Crime, shame and reintegration. 16. imp. Nova Iorque: Cambridge, 2006.

BRANCHER, Leoberto; AGUINSKY, Beatriz. Juventude, crime e justiça: uma promessa impagável? In: ILANUD et al (Org.). Justiça, adolescente e ato infracional: socioeducação e responsabilização. São Paulo: ILANUD, 2006. p. 469-493.

BRETAN, Maria Emília Accioli Nobre. Os múltiplos olhares sobre o adolescente e o ato infracional: análises e reflexões sobre teses e dissertações da USP e da PUCISP (1990 _ 2006). 2008. 223f. Dissertação (Mestrado em Criminologia) - Faculdade de Direito, Universidade de São Paulo, [2008].

BRUM, Isis. O mapa dos infratores. Diário de São Paulo, São Paulo, p. 3 A, 25 nov. 2007.

BRUÑOL, Miguel Cillero. "Nulla poena sine culpa”. Un límite necesario al castigo penal de los adolescentes. In: GARCÍA MÉNDEZ, Emilio. (Comp.). Adolescentes y responsabilidad penal. Buenos Aires: Ad-Hoc, 2001. p. 71-85.

BUSTOS RAMÍREZ, Juan. La Criminología. In: BERGALLI, Roberto;

MIRALlES, Teresa. El Pensamiento CriminológicoI: un análisis crítico. Bogotá: Temis, 1983. p. 15-26. v. 1.

Criminología y evolución de las ideas sociales. In: BERGALLI, Roberto;

MIRALLES, Teresa. El Pensamiento Criminológico: un análisis crítico. Bogotá: Temis, 1983. p. 27-48. v. 1. 
Hacia la desmitificación de la facultad reformadora de menores: por um derecho penal de menores. In: (Dir.). Un Derecho Penal del Menor. Santiago: Conosur, 1992.

Perspectivas de un Derecho Penal del Niño. Nueva Doctrina Penal, Buenos Aires, v. A, p. 63-71, 1997.

CAMARGO SOBRINHO, Mário. Algumas considerações sobre o adolescente infrator face à legislação nacional e alienígena. Revista Jurídica da Universidade de Franca, Franca, v. 3, n. 4, p. 99-116, mai. 2000.

CASTRO, Ana Márcia de Souza. Alternativas ao jovem infrator. Revista do ILANUD, São Paulo, n. 12, p. 17-24, 1998.

CASTRO, Lola Aniyar de. Criminologia da reação social. Tradução de Ester Kosovski. Rio de Janeiro: Forense, 1983.

CERQUEIRA, Carlos Magno Nazareth; PRADO, Geraldo. A polícia diante da infância e juventude: Infração e vitimização. Rio de Janeiro: Feitas Bastos, 1999.

CICOUREL, Aaron V. Method and measurement in Sociology. 2. imp. Nova Iorque: The Free Press, 1966.

La sociologie cognitive. Tradução de Jeffrey e Martine Olson. Paris: Presses Universitaires de France, 1979.

CID MOLINÉ, José; LARRAURI PIJOAN, Helena. Teorías Criminológicas: explicación y prevención de la delincuencia. Barcelona: Bosh, 2001.

CHRISTIE, Nils. El delito no existe. In: BAIGÚN, David et al. Estudios sobre Justicia Penal. Buenos Aires: Del Puerto, 2005. p. 553-561.

COHEN, Albet K. Delinquent boys. Londres: Routledge \& Kegan Paul, 1958. 
Comportamento aberrante e seu controle. Tradução de Octavio Mendes Cajado. In: PARSONS, Talcott (Org.). A Sociologia Americana. São Paulo: Cultrix, 1970. p. 271284.

COHEN, Stanley. Esceptismo intelectual y compromiso político: la Criminología Radical. Delito y sociedad: Revista de Ciencias Sociales, Buenos Aires, v. 3, n. 4-5, p. 3-31, $1993 I 1994$.

COOLEY, Charles Horton. Sociological theory and social research. Nova Iorque: Henry Holt, 1930.

COSER, Lewis A.; ROSENBERG, Bernard. American antecedents of the sociology of knowledge. In: COSER, Lewis A.; ROSENBERG, Bernard (Ed.). Social theory: a book of readings. Nova Iorque: Macmillan, 1957. p. 565-569.

COSTA, Álvaro Mayrink da. Criminologia. 3. ed. Rio de Janeiro: Forense, 1982.

COSTA, Ana Paula Motta. As garantias processuais e o Direito Penal Juvenil como limite na aplicação da medida socioeducativa de internação. Porto Alegre: Livraria do Advogado, 2005.

COSTA, Antônio Carlos Gomes da. Natureza e essência da ação socioeducativa. In: ILANUD et al (Org.). Justiça, adolescente $e$ ato infracional: socioeducação e responsabilização. São Paulo: ILANUD, 2006. p. 449-467.

COULON, Alain. Etnometodologia. Tradução de Ephraim Ferreira Alves. Petrópolis: Vozes, 1995.

CURY, Munir; GARRIDO DE PAULA, Paulo Afonso; MARÇURA, Jurandir Norberto. Estatuto da Criança e do Adolescente Anotado. 3. ed. São Paulo: Revista dos Tribunais, 2002. 
; SILVA, Antônio Fernando Amaral e; GARCÍA MENDEZ, Emílio (Coord.).

Estatuto da Criança e do Adolescente Comentado: Comentários jurídicos e sociais. 5. ed. São Paulo: Malheiros, 2002.

DAHRENDORF, Ralf. As classes e seus conflitos na sociedade industrial. Tradução de José Viegas. Brasília: Editora Universidade de Brasília, 1982. (Coleção Pensamento Político).

A lei e a ordem. Tradução de Tâmara D. Barile. Brasília: Instituto Tancredo Neves, 1987.

O conflito social moderno. Um ensaio sobre a política da liberdade. Tradução de Renato Aguiar e Marco Antônio Esteves da Rocha. Rio de Janeiro: Jorge Zahar; São Paulo: Edusp, 1992.

DEBUYST, Christian; DIGNEFFE, Françoise; LABADIE, Jean-Michel; PIRES, Alvaro P. Histoire des savoirs sur le crime \& la peine. Bruxelas: De Boeck-Wesmael, 1995. v. 1.

DEL-CAMPO, Eduardo R. A. Prescrição sócio-educativa: a Súmula 338 do STJ. Carta Forense, São Paulo, n. 57, p. 42-43, fev. 2008.

DEL OMO, Rosa. A América Latina e sua Criminologia. Rio de Janeiro: Revan, 2004. (Instituto Carioca de Criminologia. Coleção Pensamento Criminológico, 9).

DESLAURIERS, Jean-Pierre; KÉRISIT, Michèle. O delineamento de pesquisa qualitativa. In: SALLUM JÚNIOR, Basílio (Coord.). A pesquisa qualitativa: Enfoques epistemológicos e metodológicos. Petrópolis: Vozes, 2008. p. 127-153.

DIAS, Camila Caldeira Nunes. A igreja como refúgio e a Bíblia como esconderijo? Conversão religiosa, ambiguidade e tensão entre presos evangélicos e massa carcerária. Dissertação (Mestrado em Sociologia) - Faculdade de Filosofia, Letras e Ciências Humanas, Universidade de São Paulo, [2005]. 
DIAS, Jorge de Figueiredo; ANDRADE, Manuel da Costa. Criminologia: o homem delinqüente e a sociedade criminógena. 2 reimp. Coimbra: Coimbra Editora, 1997.

DIAZ, Eliseo del Blanco. La reforma de Menores: Diseño procesal de la Ley 4I92: Princípios y Derechos Fundamentales inherentes al proceso. Estúdios del Ministério Fiscal, Madri, n. 3, p. 603-612, 1995.

DOLZ LAGO, Manuel Jesús. Justicia de Menores: aspectos de un procedimiento en crisis ante la crisis de los procedimientos penales. Actualidad Penal, Madri, v. 2, p. 953-967, dez. 1996.

DURKHEIM, Émile. El suicidio. Tradução de Mariano Ruiz-Funes. Madri: Editorial Reus, 1928.

La división del trabajo social. Tradução de Carlos G. Posada. Madri: Daniel Jorro, 1928.

As regras do método sociológico. Tradução de Maria Isaura Pereira de Queiroz. 9. ed. São Paulo: Editora Nacional, 1978.

EINSTADTER, Werner J.; HENRY, Stuart. Criminological theory: an analysis of its underlying assumptions. 2. ed. Nova Iorque: Rowman \& Littlefield, 2006.

ELBERT, Carlos Alberto. Menores em situación irregular y proyectos legislativos en la Argentina actual. Doctrina Penal: Teoría y Práctica en las Ciencias Penales, Buenos Aires, v. 11, n. 41-44, p. $443-459,1988$.

Manual Básico de Criminologia. Tradução de Ney Fayet Júnior. Porto Alegre: Ricardo Lenz, 2003.

. La inseguridad, el derecho y la política criminal del siglo XXI. In: BAIGÚN, David et al. Estudios sobre Justicia Penal. Buenos Aires: Del Puerto, 2005. p. 563-577. 
FELLINI, Zulita. La nueva legislación penal mexicana sobre menores infractores, en el marco de la declaración sobre los derechos del niño. Doctrina Penal: Teoría y Práctica en las Ciencias Penales, Buenos Aires, v. 14, n. 55-56, p. 623-630, jul.Idez. 1991.

FERNANDES, Newton e Valter. Criminologia Integrada. 2. ed. São Paulo: Revista dos Tribunais, 2002.

FERRAJOLI, Luigi. Direito e Razão: teoria do Garantismo Penal. Tradução de Ana Paula Zomer Sica et al. 2. ed. São Paulo: Revista dos Tribunais, 2006.

FERREIRA, Luiz Antonio Miguel. Execução das medidas socioeducativas em meio aberto: prestação de serviços à comunidade e liberdade assistida. In: ILANUD et al (Org.). Justiça, adolescente e ato infracional: socioeducação e responsabilização. São Paulo: ILANUD, 2006. p. 397-426.

FERRO, Ana Luiza Almeida. Robert Merton e o funcionalismo. Belo Horizonte: Mandamentos, 2004. (Coleção Ciências Criminais, 11).

FONTALVO, Jorge Restrepo. Criminología: un enfoque humanístico. 3. ed. Colômbia: Temis, 2002.

FOUCAULT, Michel. Vigiar e punir. Tradução de Raquel Ramalhete. 32. ed. Petrópolis: Vozes, 1987.

FRANCO, Alberto Silva. Leis Penais Especiais e sua interpretação jurisprudencial. 6. ed. São Paulo: Revista dos Tribunais, 1997.

FRASSETO, Flávio Américo. Esboço de um roteiro para aplicação das medidas socioeducativas. Revista Brasileira de Ciências Criminais, São Paulo, a. 7, n. 26, p. 159195, abr.jun. 1999.

- Execução da medida sócio-educativa de internação: primeiras linhas de uma crítica garantista. In: ILANUD et al (Org.). Justiça, adolescente e ato infracional: socioeducação e responsabilização. São Paulo: ILANUD, 2006. p. 303-341. 
GARCÍA DE PAZ, Maria Isabel Sánchez. Minoría de edad y derecho penal juvenil. Granada: Comeres, 1998.

La nueva ley reguladora de la responsabilidad penal del menor. Actualidad Penal, Madri, n. 33, p. 699-729, set. 2000.

GARCÍA MÉNDEZ, Emilio. La Convención Internacional de los Derechos de la Infancia: del menor como objeto de la compasión-represión a la infancia-adolescencia como sujeto de derechos. Capítulo Criminológico, Maracaíbo, n. 18/19, p. 177-193, 1990-1991.

Política de la infancia/adolescencia en América Latina. Estado, movimiento social y modelo jurídico-institucional: tendencias y perspectivas. Doctrina Penal: Teoría y práctica en las Ciencias Penales, Buenos Aires, a. 14, n. 55/56, p. 479-489, jul./dez. 1991.

Infancia, ley y democracia: uma cuestión de justicia. Ciencias Penales: Revista de la Asociación de Ciencias Penales de Costa Rica, Costa Rica, a.10, n. 15, p. 58-71, dez. 1998.

. Evolución historica del derecho de la infancia: Por que uma historia de los derechos de la infância? In: ILANUD et al (Org.). Justiça, adolescente e ato infracional: socioeducação e responsabilização. São Paulo: ILANUD, 2006. p. 7-23.

GARCÍA-PABLOS DE MOLINA, Antonio. La supuesta función resocializadora del Derecho Penal: utopia, mito y eufenismo. Anuario de Derecho Penal y Ciencias Penales, Madri, v. 32, n. 2, p. 645-700, mai.Iago. 1979.

La normalidad del delito y el delincuente. Revista de la Facultad de Derecho de la Universidad Complutense, Madri, n. 11, p. 325-346, jun. 1986.

. La aportación de la Criminología. Eguzkilore. Cuaderno del Instituto Vasco de Criminología, San Sebastián, n. 3, p. 79-94, dez. 1989. 
Criminologia: uma introdução a seus fundamentos teóricos. Tradução de Luiz Flávio Gomes. São Paulo: Revista dos Tribunais, 1992.

Momento actual de la reflexión criminológica. Estudios del Ministério Fiscal, Madri, n. 1, p. 573-596, 1994.

Análisis criminológico de los diversos modelos y sistemas de reacción al delito. In: CEREZO MIR, José et al (Ed.). El Nuevo Código Penal: presupuestos y fundamentos. Granada: Comares, 1999. p. 135-160.

. Tratado de Criminología. 2. ed. Valência: Tirant lo blanch, 1999.

. La prevención del delito: reflexiones en torno a la denominada 'prevención situacional'. In: José Luis Guzmán Dalbora (Coord.) El penalista liberal. Buenos Aires: Hammurabi, 2004. p. 613-646.

Modelo clásico, libero arbitrista, de la opción racional y teorías situacionales de la criminalidad. In: ALONSO GARCÍA, Ricardo et al (Cons. Ed.). Homenaje al Profesor Dr. Rodríguez Mourullo. Navarra: Aranzadi, 2005. p. 401-423.

GARFINKEL, Harold. Studies in Ethnomethodology. Nova Jersey: Prentice-Hall, 1967.

GARRIDO, Elena Azaola. La ilusión de la 'verdad' en la investigación de menores delincuentes. Doctrina Penal: Teoría y Práctica en las Ciencias Penales, Buenos Aires, v. 12. n. $45-48$, p. 237-249, 1989.

Análisis institucional e instituiciones normalizadoras: un estudio sobre las instituiciones correccionales en México. Doctrina Penal: Teoría y Práctica en las Ciencias Penales, Buenos Aires, v. 13, n. 49-53, p. 9-21, 1990.

GARRIDO, Vicente; STANGELAND, Per; REDONDO, Santiago. Principios de Criminología. 2. ed. Valência: Tirant lo blanch, 2001. 
Qué és la Psicología Criminológica. Madrid: Biblioteca Nueva, 2005.

GARRIDO DE PAULA, Paulo Afonso. Ato infracional e natureza do sistema de responsabilização. In: ILANUD et al (Org.). Justiça, adolescente e ato infracional: socioeducação e responsabilização. São Paulo: ILANUD, 2006. p. 25-48.

GASSIN, Raymond. Criminologie. 3. ed. Paris: Dalloz, 1994.

GERSÃO, Eliana. Menores agentes de infrações: interrogações acerca de velhas e novas respostas. Revista Portuguesa de Ciência Criminal, Coimbra, v. 4, n. 2, p. 241-259, abr.Ijun. 1994.

. Ainda a revisão da Organização Tutelar de Menores: memória de um processo de reforma. In: DIAS, Jorge de Figueiredo et al (Org.). Estudos em homenagem a Cunha Rodrigues. Coimbra: Coimbra Editora, 2001. p. 447-476. v. 1.

GIMÉNEZ-SALINAS COLOMER, Esther. Tratamiento jurídico de la delincuencia de menores en España. Doctrina Penal: Teoría y práctica en las ciencias penales, Buenos Aires, v. 4, n. 13-16, p. 261-278, 1981.

. La justicia de menores en el siglo XX: uma gran incógnita. In: BUSTOS RAMÍREZ, Juan (Dir.). Un Derecho Penal del Menor. Santiago de Chile: Conosur, 1992. p. 11-53.

La mediación en el sistema de justicia juvenil: uma visión desde el derecho comparado. Eguzkilore. Cuaderno del Instituto Vasco de Criminología, San Sebastián, n. 10, p. 193-212, dez. 1996.

. Características principales de la Ley Orgánica reguladora de la responsabilidad penal del menor. Revista del Poder Juducial, Madri, n. 60, p. 137-157, 2000.

GOFFMAN, Erving. A representação do eu na vida cotidiana. Tradução de Maria Célia Santos Raposo. Petrópolis: Vozes, 1975. (Coleção Antropologia, 8). 
. Estigma: notas sobre a manipulação da identidade deteriorada. Tradução de Márcia Bandeira de Mello Leite Nunes. 4. ed. Rio de Janeiro: LCT, 1988.

. Manicômios, prisões e conventos. Tradução de Dante Moreira Leite. 8. ed. São Paulo: Perspectiva, 2008. (Coleção Debates).

GOMES NETO, Gercino Gerson. O adolescente autor de ato infracional frente aos princípios e garantias do Estatuto da Criança e do Adolescente. Revista do ILANUD, São Paulo, n. 14, p. 43-53, 2001.

GÓMEZ, Manuel Marchena. A Justiça de Menores em Espanha: tempos de reforma. Revista do Ministério Público, Lisboa, v. 19, n. 73, p. 117-124, jan. Imar. 1998.

GÓMEZ RIVERO, Maria Carmen. Algunos aspectos de la Ley Orgânica 5/2000, de 12 de enero, reguladora de la responsabilidad penal del menor. Actualidad Penal, Madri, n. 10, p. 163-187, 2001.

GONZALEZ, Alberto Brusa. Experiências socioeducativas bem-sucedidas: subsídios para a discussão de políticas públicas nas unidades de internação socioeducativas (UISE). In: ILANUD et al (Org.). Justiça, adolescente $e$ ato infracional: socioeducação e responsabilização. São Paulo: ILANUD, 2006. p. 539-571.

GROSNER, Marina Quezado. A seletividade do sistema penal na jurisprudência do Superior Tribunal de Justiça: o trancamento da criminalização secundária por decisões em habeas corpus. São Paulo: IBCCRIM, 2008.

GUIRADO, Marlene. Em instituições para adolescentes em conflito com a lei, o que pode a nossa vã psicologia? In: GONÇALVES, Hebe Signorini; BRANDÃO, Eduardo Ponte (Org.). Psicologia Jurídica no Brasil. 2. ed. Rio de Janeiro: Nau, 2005. p. 249-276.

HERRERO, César Herrero. Criminologia. 2. ed. Madri: Dykinson, 2001. 
HIRST, Paul Q. Marx y Engels sobre la ley, el delito y la moralidad. Tradução de Nicolas Grab. In: TAYLOR, Ian; WALTON, Paul; YOUNG, Jock (Dir.). Criminología Crítica. Cerro del Agua, Madri, Bogotá: Siglo veintiuno, 1977. p. 255-287.

HOOD, Roger; SPARKS, Richard. Problemas clave em criminologia. Tradução de Angeles Escudero. Madri: Guadarrama, 1970.

HOULE, Gilles. A sociologia como ciência da vida: a abordagem biográfica. Tradução de Ana Cristina Nasser. In: SALLUM JÚNIOR, Basílio (Coord.). A pesquisa qualitativa: Enfoques epistemológicos e metodológicos. Petrópolis: Vozes, 2008. p. 317-334.

HUMAN RIGHTS WATCH. Site. Disponível em: $<$ http://www.hrw.orgIspanish/inf_anual/2000Iamericas/brasil.html>. Acesso em: 1 de dez. 2009.

ISHIDA, Valter Kenji. Estatuto da Criança e do Adolescente: doutrina e jurisprudência. 8. ed. São Paulo: Atlas, 2006.

JIMÉNEZ DE ASÚA, Luis. Tratado de Derecho Penal. 5.ed, Buenos Aires: Losada, 1950. v. 1 . . Tratado de Derecho Penal. 5.ed, Buenos Aires: Losada, 1950. v. 2.

JUNQUEIRA, Ivan de Carvalho. Do ato infracional à luz dos Direitos Humanos. Campinas: Russell, 2009.

KAISER, Gunter. Introducción a la Criminología. Tradução de José Arturo Rodríguez Núñez. 7. ed. Madri: Dykinson, 1988.

KING, Martin Luther. Discurso no primeiro comício da Associação pelo Progresso de Montgomery. In: CARSON, Clayborne; SHEPARD, Kris (Org.). Um apelo à consciência: os melhores discursos de Martin Luther King. Tradução de Sérgio Lopes. Rio de Janeiro: Zahar, 2006. p. 23-26. 
. Eu estive no topo da montanha. In: CARSON, Clayborne; SHEPARD, Kris

(Org.). Um apelo à consciência: os melhores discursos de Martin Luther King. Tradução de Sérgio Lopes. Rio de Janeiro: Zahar, 2006. p. 163-171.

KONZEN, Afonso Armando. Reflexões sobre a medida e sua execução (ou sobre o nascimento de um modelo de convivência do jurídico e do pedagógico na socioeducação). In: ILANUD et al (Org.). Justiça, adolescente $e$ ato infracional: socioeducação e responsabilização. São Paulo: ILANUD, 2006. p. 343-365.

KUHN, Thomas S. A estrutura das revoluções científicas. Tradução de Beatriz Viana Boeira e Nelson Boeira. 8. ed. São Paulo: Perspectiva, 1982. (Coleção Debates).

LARRAURI, Elena. La herencia de la criminología crítica. 2. ed. Madri: Siglo veintiuno de España, 2000.

LEMERT, Edwin M. Social Pathology: a systematic approach to the theory of sociopathic behavior. 1. ed. Nova Iorque: Toronto: Londres: McGraw-Hill, 1951.

LIBERATI, Wilson Donizeti. Comentários ao Estatuto da Criança e do Adolescente. 7. ed. São Paulo: Malheiros, 2003.

. Execução de medida socioeducativa em meio aberto: prestação de serviços à comunidade e liberdade assistida. In: ILANUD et al (Org.). Justiça, adolescente e ato infracional: socioeducação e responsabilização. São Paulo: ILANUD, 2006. p. 367-395.

Processo Penal Juvenil: a garantia da legalidade na execução de medida socioeducativa. São Paulo: Malheiros, 2006.

LILLY, Robert J.; CULLEN, Francis T.; Ball, Richard A. Criminological theory: context and consequences. 2. ed. Sage: Thousand Oaks, 1995.

LIMA, Rita de Cássia Pereira. Sociologia do desvio e interacionismo. Tempo Social. Revista de Sociologia da USP, São Paulo, v. 13, n. 1, p. 185-201, mai. 2001. 
LINK, Arthur S. História moderna dos Estados Unidos. Tradução de Waltensir Dutra Álvaro Cabral e Fernando de Castro Ferro. Rio de Janeiro: Zahar, 1965.

LYRA, Roberto; JÚNIOR, João Marcello de Araújo. Criminologia. 2 ed. Rio de Janeiro: Forense, 1990.

LUCCHINI, Riccardo. Le débat brésilien sur la Justice des Mineurs. Déviance et Societé, Liège, v. 15, n. 2, p. 175-186, 1991.

MACHADO, Martha de Toledo. Sistema especial de proteção da liberdade do adolescente na Constituição brasileira de 1988 e no estado da criança e do adolescente. In: ILANUD et al (Org.). Justiça, adolescente e ato infracional: socioeducação e responsabilização. São Paulo: ILANUD, 2006. p. 87-121.

MADRENAS I BOADAS, Carme. Una visión de la teoría de las subculturas criminales: Albert K. Cohen, y Richard A. Cloward y LLoyd e Ohlin. Doctrina Penal: Teoria y Práctica en las Ciências Penales, Buenos Aires, v. 5, n. 17-20, p. 435-461, 1982.

MAÍlLO, Alfonso Serrano. Introdução à Criminologia. Tradução de Luiz Régis Prado. São Paulo: Editora Revista dos Tribunais, 2007.

MANNHEIM, Hermann. Criminologia Comparada. Lisboa: Calouste Gulbenkian, 1984. v. 2.

MASSA, Patrícia Helena. A menoridade Penal no Direito Brasileiro. Revista Brasileira de Ciências Criminais, São Paulo, ano 1, n. 4, p. 126-132, out./dez. 1993.

MEAD, George H. Espíritu, Persona y Sociedad. Tradução de Florial Mazía. Buenos Aires: Paidos, 1953.

MELOSSI, Dario; PAVARINI, Massimo. Cárcere e fábrica: as origens do sistema penitenciário: séculos XVI-XIX. Rio de Janeiro: Revan, 2006. (Instituto Carioca de Criminologia. Coleção Pensamento Criminológico, 11). 
MENDES, Luiz Alberto. Memórias de um sobrevivente. 2.reimp. São Paulo: Companhia das Letras, 2005.

MERTON, Robert K. Sociologia: teoria e estrutura. São Paulo: Mestre Jou, 1970.

MIR PUIG, Santiago. ¿Que queda en pie de la resocialización? Eguzkilore. Cuaderno del Instituto Vasco de Criminología, San Sebastián, n. 2 (ext.), p. 35-41, out. 1989.

MISSE, Michel. Sobre o "conceito" de conflito social. In: ROSA, F. A. de Miranda (Org.). Direito e Conflito social. Rio de Janeiro: Zahar, 1981. p. 17-46.

MITCHELL, Wagner Gustavo. La necesidad de imponer pena al menor: art. 4 de la ley 22.278. Doctrina Penal: Teoría y Práctica en las Ciencias Penales, Buenos Aires, v. 4, n. $13-16$, p. 521-531, 1981.

MONACO, Gustavo Ferraz de Campos. A Declaração Universal dos Direitos da Criança e seus sucedâneos internacionais: tentativa de sistematização. Coimbra: Coimbra, 2004.

MONDRAGÓN, Geraldo Bohórquez; CHINGAL, Elkin Paez. A medida socioeducativa de internação: uma construção de relações. In: ILANUD et al (Org.). Justiça, adolescente $e$ ato infracional: socioeducação e responsabilização. São Paulo: ILANUD, 2006. p. 573592.

MORRIS, Charles W. George H. Mead como psicólogo y filósofo social. In: MEAD, George H. Espíritu, Persona y Sociedad. Tradução de Florial Mazía. Buenos Aires: Paidos, 1953. p. 23-48.

NARVAZ, Martha Giudice; KOLLER, Sílvia Helena. Metodologias feministas e estudos de gênero: articulando pesquisa, clínica e política. Disponível em < http://www.scielo.br/pdf/pe/v11n3/v11n3a20.pdf > Acesso em 29 out. 2009.

NEVINS, Allan; COMMAGER, Henry Steele. Breve história dos Estados Unidos. Tradução de Luiz Roberto de Godói Vidal. 7. ed. São Paulo: Alfa-Omega, 1986. 
NICODEMOS, Carlos. Menoridade Penal: inimputabilidade x impunidade: desafios para o próximo século. Revista da Faculdade de Direito de Valença, Valença, v. 2, n. 2, p. 106114, dez. 1999.

- A natureza do sistema de responsabilização do adolescente autor de ato infracional. In: ILANUD et al (Org.). Justiça, adolescente e ato infracional: socioeducação e responsabilização. São Paulo: ILANUD, 2006. p. 61-85.

NÚCLEO DE ESTUDOS DA VIOLÊNCIA. Disponível em: $<$ http://www.nevusp.org/portugues/index.php?option=com_content\&task=view\&id=1792 \&Itemid=155>. Acesso em: 1 de dez. 2009.

NUNES, Jordão Horta. Interacionismo simbólico e dramaturgia: a sociologia de Goffman. São Paulo: Humanitas, 2005.

OBERSCHALL, Anthony. Social movements: ideologies, interests and identities. Nova Brunswick: Transaction, 1997.

OLIVEIRA, William Terra de. Situación actual del derecho de los menores: Brasil. Revista Penal, Barcelona, n. 5, p. 152-155, jan. Idez. 1998.

PARSONS, Talcott. Uma visão geral. Tradução de Octavio Mendes Cajado. In: (Org.). A Sociologia Americana. São Paulo: Cultrix, 1970. p. 366-383.

PASSETTI, Edson. Violentados: crianças, adolescentes e justiça. São Paulo: Imaginário. 1995.

PATERNOSTER, Raymond; IOVANNI, Leeann. The labeling perspective and delinquency: An elaboration of the theory and an assessment of the evidence. In: CORDELLA, Peter; SIEGEL, Larry (Ed.). Readings in contemporary criminological theory. Boston: Northeastern University, 1996. p. 171-188. 
PAULILO, Maria Ângela Silveira. A pesquisa qualitativa e a história de vida. Serviço Social em Revista, Londrina, v. 2, n. 1, jul./dez. 1999. Disponível em: <http://www.ssrevista.uel.br/?c_v2n1_pesquisa.htm>. Acesso em 07 dez. 2009.

PAVARINI, Massimo. Da perda da pena ao seu reencontro: reflexões sobre uma 'procura'. In: ZOMER, Ana Paula (Org.). Ensaios Criminológicos. São Paulo: IBCCRIM, 2002. p. 91-125.

. Processos de recarcerização e 'novas' teorias justificativas da pena. In: ZOMER, Ana Paula (Org.). Ensaios Criminológicos. São Paulo: IBCCRIM, 2002. p. 127-167.

Procesos de re-encarcelamiento en el mundo, o bien del dominio de un cierto "punto de vista". In: BAIGÚN, David et al. Estudios sobre Justicia Penal. Buenos Aires: Del Puerto, 2005. p. 595-609.

PEDRINHA, Roberta Duboc. Sexualidade, controle social e práticas punitivas: do signo sacro religioso ao modelo científico médico higienista. Rio de Janeiro: Lumen Juris, 2009.

PIRES, Álvaro P. Amostragem e pesquisa qualitativa: ensaio teórico e metodológico. In: SALLUM JÚNIOR, Basílio (Coord.). A pesquisa qualitativa: Enfoques epistemológicos e metodológicos. Petrópolis: Vozes, 2008. p. 154-211.

REVEL, Jean-Francois. A revolução imediata. Tradução de Maria Emília Mauhin. Lisboa: Bertrand, 1970.

ROBERT, Philippe. La conquête de l'autonimie à travers l'histoires. Problèmes politiques et sociaux: Justice Penale de Mineurs. Paris, n. 935, p. 13-15, abr. 2007.

ROCHA, Dulce. Violações dos direitos da criança em Potugal. Direito das Crianças, Coimbra, n. 3, p. 13-22, 2004.

RODRIGUES, Gutemberg Alexandrino. Os filhos do mundo: a face oculta da menoridade (1964-1979). São Paulo: IBCCRIM, 2001 
RODRIGUES, Saulo Tarso. Criminologia: A política criminal alternativa e os princípios de direito penal mínimo de Alessandro Baratta: na busca da (re) legitimação do sistema penal. São Paulo: Ômega, 2003.

ROMERA, Mário. Uma regressão do (no) Estatuta da Criança e do Adolescente (ECA). Revista do Ministério Público, Porto Alegre, n. 46, p. 209-219, jan. /mar. 2002.

ROSA, Alexandre Morais da. Aplicando o ECA: felicidade e perversão sem limites. Revista Brasileira de Ciências Criminais, São Paulo, v. 14, n. 58, p. 15-28, jan. /fev. 2006.

Introdução crítica ao ato infracional: princípios e garantias constitucionais. Rio de Janeiro: Lumen Juris, 2007.

ROSAL BLASCO, Bernardo del. Joven delincuente y Derecho Penal. Cuadernos de Política Criminal, Madri, n. 54, p. 1037-1051, 1994.

ROSS, Edward A. Social control. In: COSER, Lewis A.; ROSENBERG, Bernard (Ed.). Social theory: a book of readings. Nova Iorque: Macmillan, 1957. p. 99-101.

ROXIN, Claus. Problemas fundamentais de Direito Penal. Tradução de Ana Paula dos Santos et al. 3. ed. Lisboa: Vega, 1998.

RUIDÍAZ GARCÍA, Carmen. Una mirada a la vida en las prisiones: los reclusos y su mundo. Cuadernos de Política Criminal, Madri, n. 54, p. 1443-1457, 1994.

RUSCHE, Georg; KIRCHHEIMER, Otto. Punição e estrutura social. Tradução de Gizlene Neder. Rio de Janeiro: Freitas Barros, 1999. (Instituto Carioca de Criminologia. Coleção Pensamento Criminológico, 3).

RÜTHER, Werner. La criminalidad (o el "delincuente") a traves de las definiciones sociales (o etiquetamiento). Doctrina Penal: Teoría y Práctica en las Ciencias Penales, Buenos Aires, v. 1, n. 1-4, p. 749-764, 1978. 
SÁ, Alvino Augusto de. Prisionização: Um dilema para o cárcere e um desafio para a comunidade. Revista Brasileira de Ciências Criminais, São Paulo, a. 6, n. 21, p. 117-123, jan. /mar. 1998.

Algumas ponderações acerca da reintegração social dos condenados à pena privativa de liberdade. Disponível em <www.eap.sp.gov. br/ponderacoes.pdf>. Acesso em 25 mai. 2007.

O caos penitenciário... seria mesmo um caos? Boletim do Instituto Brasileiro de Ciências Criminais, São Paulo, a. 17, n. 203, p. 15-16, out.2009.

SÁ, Sidnei Boccia Pinto de Oliveira. Medidas sócio-educativas e sanções penais. De Jure: Revista Jurídica do Ministério Público do Estado de Minas Gerais, Belo Horizonte, n. 6, p. 179-199, jan. /jun. 2006.

SAENZ, Fabiana Eduardo. Política Criminal e limite etário de responsabilização penal. 2008. 218f. Dissertação (Mestrado em Criminologia) - Faculdade de Direito, Universidade de São Paulo, [2008].

SALDAÑA, Quintiliano. Nova Criminologia. Tradução de Alfredo Ulson e V. de Alcântara Carreira. 2. ed. Campinas: Russel, 2006.

SALDARRIAGA, Victor Prado. Situación actual del derecho de los menores: Peru. Revista Penal, Barcelona, n. 5, p. 182-186, jan. 2000.

SANTOS, Juarez Cirino dos. A Criminologia Radical. Rio de Janeiro: Forense, 1981.

SANTOS, Marco Antônio Cabral dos. Criança e criminalidade no início do século. In: DEL PRIORE, Mary (Org.). História das crianças no Brasil. São Paulo: Contexto, 2007. p. 210-230.

SANTOS, Maria Celeste Cordeiro Leite. Raízes da violência na criança e futuros danos psíquicos. Revista da Faculdade de Direito da Universidade de São Paulo, São Paulo, v. 96, p. 331-346, 2001. 
SARAIVA, João Batista Costa. Compêndio de Direito Penal Juvenil: adolescente e ato infracional. 3. ed. Porto Alegre: Livraria do advogado, 2006.

SCHILLING, Flávia Inês. Sobre homens e crimes: construindo um diálogo tenso entre Marx, Durkheim e Foucault. Revista Brasileira de Ciências Criminais, São Paulo, ano 4, n. 13, p. 278-285, jan. Imar. 1996.

SCHUR, Edwin M. Sociologia del diritto. Tradução de Paola Montagner. Bolonha: Mulino, 1970.

SCHUTZ, Alfred. Fenomenologia e relações sociais. Tradução de Ângela Melin. In: Wagner, Helmut R. (Org). Fenomenologia e relações sociais. Rio de Janeiro: Zahar, 1979.

SELLIN, Thorsten. Le sociologue et le problème du crime. Revue de Science Criminelle et de Droit Penal Comparé, Paris, n. 4, p. 527-539, oct./dec. 1950.

. L'effet intimidant de la peine: étude de sociologie criminelle. Revue de Science Criminelle et de Droit Penal Comparé, Paris, n. 4, p. 579-593, oct.ldec. 1960.

SHAW, Clifford R; MCKAY, Henry D. Juvenile Deliquency and urban areas. Chicago: University of Chicago, 1942.

The Jack-Roller: A delinquent boy's own history. Chicago: The University of Chicago, 1992.

SHECAIRA, Sérgio Salomão. Sistema de Garantias e o Direito Penal Juvenil. São Paulo: Revista dos Tribunais, 2008.

. Criminologia. 2. ed. rev. São Paulo: Revista dos Tribunais, 2008.

SHILS, Edward. Sociedade e sociedades: o ponto de vista macrossociológico. Tradução de Octavio Mendes Cajado. In: PARSONS, Talcott (Org.). A Sociologia Americana. São Paulo: Cultrix, 1970. p. 332-349. 
SHOEMAKER, Donald J. Theories of deliquency: an examination of explanations of delinquent behavior. 3. ed. Nova Iorque: Oxford University, 1996.

SICA, Ana Paula Zomer. Prevenção Criminal: análise de políticas extrapenais. Rio de Janeiro: Lumen Juris, 2009.

SILVA, Antônio Fernando do Amaral e. A "proteção" como pretexto para o controle social arbitrário de adolescentes e a sobrevivência da doutrina da situação irregular. Revista do ILANUD, São Paulo, n. 20, p. 7-15, 2002.

O Estatuto da Criança e do Adolescente e o sistema de responsabilidade penal juvenil ou o mito da inimputabilidade penal. In: ILANUD et al (Org.). Justiça, adolescente e ato infracional: socioeducação e responsabilização. São Paulo: ILANUD, 2006. p. 49-59.

SILVA, Roberto da. Os Filhos do Governo: A formação da identidade criminosa em crianças órfãs e abandonadas. São Paulo: Ática, 1997.

O que é institucionalização/prisionalização. Discursos Sediciosos: crime, direito e sociedade, Rio de Janeiro, a. 4, n. 7-8, p. 125-134, 1999.

SOARES, Janine Borges. A construção da responsabilidade penal do adolescente no Brasil: uma breve reflexão histórica. Revista do Ministério Público, Porto Alegre, n. 51, p. 255-286, ago./dez. 2003.

SOARES, Orlando. Criminologia. Rio de Janeiro: Freitas Bastos, 1986.

SOCIETY FOR THE STUDY OF SYMBOLIC INTERACTION. Disponível em <www.espach.salford.ac.uk/sssi >. Acesso em 8 jul. 2009.

SOTOMAYOR, Carlos Tiffer. De un Derecho Tutelar a un Derecho Penal MínimoIGarantista: nueva Ley de Justicia Penal Juvenil. Ciencias Penales. Revista de la Asociación de Ciencias Penales de Costa Rica, San José , n. 13, p. 98-109, ago. 1997. 
SOTTO MAIOR NETO, Olympio de Sá. Garantias penais do adolescente autor de ato infracional. In: ILANUD et al (Org.). Justiça, adolescente e ato infracional: socioeducação e responsabilização. São Paulo: ILANUD, 2006. p. 123-149.

SPOSATO, Karyna Batista. A Convenção Internacional das Nações Unidas sobre os Direitos da Criança: 10 anos. Revista do ILANUD, São Paulo, n. 14, p. 9-18, 2001.

Princípios e garantias para um Direito Penal Juvenil Mínimo. In: ILANUD et al (Org.). Justiça, adolescente e ato infracional: socioeducação e responsabilização. São Paulo: ILANUD, 2006. p. 247-275.

. O Direito Penal Juvenil. São Paulo: Revista dos Tribunais, 2006.

SUTHERLAND, Edwin H. Princípios de Criminologia. Tradução de Asdrúbal Mendes Gonçalves. São Paulo: Livraria Martins, 1949.

TANNEMBAUM, Frank. Crime and the community. Nova Iorque: Columbia University Press, 1951.

TAYLOR, Ian; WALTON, Paul; YOUNG, Jack. La Nueva Criminología: contribución a una teoria social de la conducta desviada. Tradução de Adolfo Crosa. Buenos Aires: Amorrortu, 1997.

TEIXEIRA, Maria de Lourdes Trassi. Evitar o desperdício de vidas. In: ILANUD et al (Org.). Justiça, adolescente e ato infracional: socioeducação e responsabilização. São Paulo: ILANUD, 2006. p. 427-447.

TELLA, Maria José Falcón; TELLA, Fernando Falcón. Fundamento e finalidade da sanção: existe um direito de castigar? Tradução de Cláudia de Miranda Avena. São Paulo: Revista dos Tribunais, 2008.

THOMPSON, Augusto F. G. Privatização prisional. In: SHECAIRA, Sérgio Salomão (Org.). Estudos Criminais em homenagem a Evandro Lins e Silva. São Paulo: Método, 2001. p. 81-96. 
TIFFER SOTOMAYOR, Carlos. De un derecho tutelar a un derecho penal mínimoIgarantista: nueva Ley de Justicia Penal Juvenil. Ciencias Penales. Revista de la Asociación de Ciencias Penales de Costa Rica, San José, v. 9, n. 13, p. 98-109, ago. 1997.

URIARTE, Carlos E. Control institucional de la niñez adolescencia en infracción: un programa mínimo de contención y límites jurídicos al Sistema Penal Juvenil (las penas de los jóvenes). Montevidéu: Carlos Alvarez, 1999.

VELO, Joe Tennyson. Postura criminológica: entre a etnometodologia e o mito de Hermes. Ciências Penais. Revista da Associação Brasileira de Professores de Ciências Penais, São Paulo, v. 2, p. 114-129, jan. /jun. 2005.

VERDIER, Raymond. Jean Carbonnier, historien-sociologue du pénal et du non-droit pénal. In: HOAREAU-DODINAU, Jacqueline; TEXIER, Pascal (Orgs.). La peine. Discours, pratiques, représentations. Paris: Pulim, 2005. p. 255-267.

VINCENTIN, Maria Cristina. A questão da responsabilidade penal juvenil: notas para uma perspectiva ético-política. In: ILANUD et al (Org.). Justiça, adolescente e ato infracional: socioeducação e responsabilização. São Paulo: ILANUD, 2006. p. 151-173.

VIDAL, Jesús Morant. La delincuencia juvenil. Disponível em <http: //noticias.juridicas.com.br>. Acesso 20 mai. 2007.

VISCARDI, Nilia. Disciplinamiento, control social y estigma: tres conceptos para una sociología del conflito: el caso de la violencia en el espacio escolar en Uruguay. Revista Sociologias, Porto Alegre, v. 1, n. 1, p. 168-199, jan. /jun. 1999.

VOLD, George B.; BERNARD, Thomas J. Theoretical Criminology. 3. ed. Nova Iorque: Oxford University Press, 1986.

VOLPI, Mário (Org.). O adolescente e o ato infracional. 3. ed. São Paulo: Cortez, 1999. 
WEINGARTNER NETO, Jayme. Maioridade penal aos 16 anos, podemos discutir? Carta Forense, São Paulo, n. 60, p. 45, mai. 2008.

YOUNG, Andrew. Introdução. In: CARSON, Clayborne; SHEPARD, Kris (Org.). Um apelo à consciência: os melhores discursos de Martin Luther King. Tradução de Sérgio Lopes. Rio de Janeiro: Zahar, 2006. p. 13-15.

ZAFFARONI, Eugenio Raúl. Os limites do aprisionamento. Fascículos de Ciências Penais, Porto Alegre, v. 1, n. 3, p. 51-55, mai. 1988.

Função da Criminologia nas sociedades democráticas. Fascículos de Ciências Penais, Porto Alegre, v. 2, n. 11, p. 163-176, nov. 1989.

. ¡Que pena! Fascículos de Ciências Penais, Porto Alegre, v. 5, n. 3, p. 127-134, jul.Iset de 1992 .

. Criminología: aproximación desde un margen. Colômbia: Temis, 1993.

Minorias desplazadas, delincuencia y poder punitivo. Eguzkilore. Cuaderno del Instituto Vasco de Criminología, San Sebastián, n. 7 (ext.), p. 83-92, dez. 1994.

. El curso de la Criminología. Ciencias Penales. Revista de la Asociación de Ciencias Penales de Costa Rica, San José, v. 12, n. 18, p. 7-11, nov. 2000.

Em busca das penas perdidas: a perda de legitimidade do sistema penal. Tradução de Vânia Romano Pedrosa e Amir Lopes da Conceição. 5. ed. Rio de Janeiro: Revan, 2001. et al. Direito Penal Brasileiro. 2. ed. Rio de Janeiro: Revan, 2003. v. 1.

ZAPPA, Regina; SOTO, Ernesto. 1968: eles só queriam mudar o mundo. Rio de Janeiro: Jorge Zahar, 2008. 